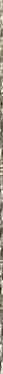

17.730

19.7.

3.7.

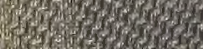

18

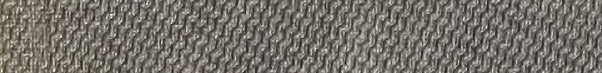

13)

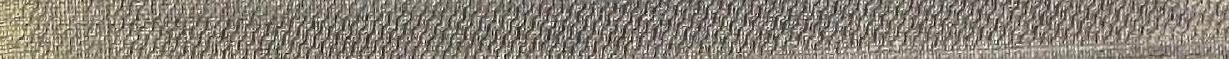




\section{Cornell University Library}

The original of this book is in the Cornell University Library.

There are no known copyright restrictions in the United States on the use of the text. 
QL 406.B82

Guide to the systematic distribution of 



\section{G U I D E}

TO THE

\section{SYSTEMATIC DISTRIBUTION}

DF

\section{MOLLUSCA}

IN THE

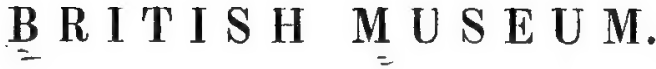

PART I.

BY

JOHN EDWARD GRAY,

PH.D., F.R.S., F.L.S., F.Z.S. \&..

LONDON :

PRINTED BY ORDER OF THE TRUSTEES.

1857. 


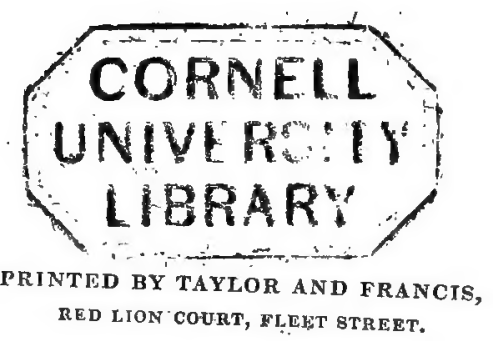




\section{PREFACE.}

The object of the present Work is to explain the manner in which the Collection of Mollusca and their shells is arranged in the British Museum, and especially to give a short account of the chief characters, derived from the animals, by which they are distributed, and which it is impossible to exhibit in the Collection.

The figures referred to after the names of the species, under the genera, are those given in "The Figures of Molluscous Animals, for the Use of Students, by Maria Emma Gray, 3 vols. 8vo, 1850 to 1854 ;" or when the species has been figured since the appearance of that work, in the original authority quoted.

The concluding Part is in hand, and it is hoped will shortly appear.

JOHN EDWARD GRAY.

Dec. $10,1856$. 


\section{ERRATA AND CORRIGENDA.}

Page 43. Verenade.-This family is to be erased, as the animal is like Trichotropis. I was misled by the incorrectness of the description and figure.

Page 63. Truodinades-This family is to be removed to Pleurobranchiata at page 203 ; a specimen of the animal and shell having since come into my possession.

Pages 135 \& 167. For Cirrhobranchia read Cirrobranchia.

Page 141. Erase Chrysogtoma, which is inserted in its correct place as part of Livona at page 156.

Paze 159. For Stomatia read Stomax. 


\section{TABLE OF CONTENTS.}

\begin{tabular}{|c|c|c|}
\hline \multicolumn{2}{|c|}{ Page } & Page \\
\hline MOLLUSCA $. . . . . . \ldots \ldots \ldots . . . .$. & & Subord. II. Proboscidifera 9 \\
\hline Symopsis of Classes & 1 & I. Edriophthalma ............ \\
\hline Class I. GASTEROPODA ... & $=$ & A. Hamiglossa ............... \\
\hline nopsis of Orders & & u. Hamiglossa vera ." \\
\hline nopsis or Urders & & Fam. 1. Cassic \\
\hline Subcl. I. Ctenobranchiata & & $\begin{array}{l}\text { a. 1. Cassidul } \\
\text { 2. Fulgur }\end{array}$ \\
\hline Ord. I. Pectinibranchiata & 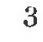 & b. 3. Coeblidium .. \\
\hline Subord. I. Toxif & & Fam. 2, Muricidee....... \\
\hline
\end{tabular}

Fam. 1. Conusida............. 4

1. Conus.................... 4

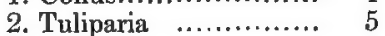

3. Rollus ............... 5

Fam. 2. Acuside ............. 5

I. Acus ................... 6

2. Subula $\ldots \ldots \ldots \ldots \ldots \ldots .6$

3. Leiodomus............. 6

4. Dorsanum ............. 7

Fam. 3. Pleurotomicice ........ 7

a. Clavatulina.

1. Clavatula

2. Tomella

b. Pleurotomina.

3. Pleurotoma ............

4. Drillia.................... 8

5. Bela .................. 8

c. Defranciina.

6. Defrancia

7. Anna

a. Muricina.

1. Murex................... 11

2. Chicoreus .............. 11

3. Trophon ................ 12

4. Typhis ................. 12

b. Colusina.

5. Colus .................. 12

6. Clavella ............... 12

7. Chrysodonius............ 13

8. Strombella............... 13

c. Pisaniana.

9. Pisania $\ldots . . . \ldots \ldots \ldots \ldots, 13$

10. Columbella $\ldots . . . \ldots \ldots, 14$

11. Engina .................. 14

12. Triumphis ............... 15

d. Cominellina.

]3. Latrunculus ........... 15

14. Cominella .............. 15

e. Nassina.

15. Bullia .................. 16

16. Nassa .................. 16

17. Desmoulea............. 17

8. Melatoma ............... 9 18. Phos .................. 17

9. Conopleura .......... 9 19. Cyllene ................ 18

10. Daphnella ......... 9 20. Northia ............... 18 
Fam. 3. Buccinida ......... I8

ค. Rapanina.

1. Rapana Rhizochilus ............ 19

2. Vitularia..............., 19

3. Chorus .................. 19

4. Cuma .................... 19

b. Purpurina.

5. Nitidella............... 20

6. Purpura ................. 20

7. Concholepas ............ 20

8. Acanthiza ............ 21

9. Sistrum ..............., 21

10. Magilus ................ 21

ᄂ. Buccinina.

11. Buccinum ............. 21

12. Gastridia $. . . . . . . \ldots . . .22$

Fam. 4. Pusionellade ........ 22

1. Pusionella ................ 22

Fam. 5. Turritida............. 23

1. Turris ................... 23

Fam. 6. Cancellariada ......... 23

1. Cancellaria............... 23

2. Admete ................ 23

Fam, 7. Olivida .............. 24

a. Olivina.

1. Strephona .............. 24

2. Olivella ................ 24

3. Scaphula ............. 25

4. Agaronia ............. 25

b. Ancillarina.

5. Ancilla ................. 25

6. Sandella .................. 26

7. Eburna ................ 26

8. Sparella ................ 26

9. Anolacia.................. 26

c. Harpalina.

10. Harpa................. 26

b. Trapezodonta................ 27

Fam. 8. Lamellariada ......... 27

1. Coriocella ............... 27

2. Lamellaria .............. 27

3. Ermea................... 28

B. Odontoglossa ........... 28

Fam. 9. Fasciolariada........ 28

a. Fasciolariana.

1. Fasciolaria .............. 28

2. Leucozonia.............. 29

3. Latius $\quad$................. 29

b. Mitrine.

4. Mitra \begin{tabular}{lr} 
& \multicolumn{2}{r}{ Page } \\
5. Strigatella ............. & 30 \\
6. Zierliana ................ & 30 \\
7. Volvaria ................ & 30 \\
8. Imbricaria .............. & 30 \\
9. Cylindra ................ & 30
\end{tabular}

Fam. 10. Turbinellide ......... 31

1. Turbinellus ............ 31

2. Cynodonta .............. 31

C. Rachiglossa .............. 31

Fam. 11. Volutida ........... 31

a. Yetina.

1. Yetus .................. 32

b. Volutina.

2. Cymbium .............. 33

3. Seapha ................. 33

4. Fulgoraria ............... 34

5. Callipara ............... 34

6. Voluta ................. 34

7. Lyria ..................... 34

8. Volutella ............... 35

c. Amoriana (Scaphellina).

9. Amoria (Cymbiola) ... 35

d. Volutomitrina.

10. Volutomitra ........... 36

e. Porcellanina.

11. Porcellana ............... 36

12. Closia ....................... 36

13. Persicula ............. 37

D. Tænioglossa............. 37

Fam. 12. Cassidida ........... 37

1. Cassis .................... 37

2. Levenia .................. 37

3. Bezoardica ................ 38

4. Morio .................... 39

5. Sconsia ................. 39

6. Linatella................... 39

7. Ranella .................. 39

8. Oniscia ................. 40

9. Morum .................. 40

10. Cithara ................... 40

11. Pachybathron .......... 40

Fam. 13. Doliid ce............. 40

1. Dolium ................... 40

2. Malea ....................... 41

3. Ringicula .............. 41

Fam. 14. Tritoniade ........ 42

1. Apollon ................... 42

2. Triton....................... 42

3. Euthria........................ 43

4. Persona ................. 43 
Fam. 15. Verenade ......... Page

1. Verena 44,77

Fam. 16. Sycotypida 1. Sycotypus

Fam. 17. Velutinide.

1. Velutina

2. Morvillia

3. Marsenina

4. Onchidiopsis

Fam. 18. Naticida a. Näticina.

1. Natica.

b. Neveritina.

2. Neverita

3. Polinices

4. Mammilla

5. Cervina

6. Naticina

7. Stomatia

8. Amaura

Fam. 19. Neritopsida

1. Neritopsis

Fam. 20. Ianthinida.

1. Ianthina

2. Recluzia

Fam. 21. Scalariade

1. Scalaria

II. Iniophthalma

A. Ptenoglossa

Fam. 22. Acteonida

1. Acteon

2. Solidula

3. Monoptygma .............

3. Monoptygm

B. Tænioglossa

Fam. 23. Cerithiopside ......

1. Cerithiopsis

C. Gymnoglossa

Fam. 24. Pyramidellide

1. Obeliscus ................

2. Pyramidella .............

3. Odostomia

4. Chemnitzia.................

5. Eulima

6. Nisso

7. Leiostraca ................

8. Menestho
9. Aclis

Page

10. Hyala ...................... 61

11. Stylina ................. 61

12. Entoconcha ........... 62

Fam. 25. Architectomida...... 62

1. Architectoma ........... 62

2. Torinia ................... 63

3. Bifrontia................. 63

Fam. 26. Tylodinada ........ 63

1. Tylodina... 63 (see p. 203)

Subord. III. Rostrifera $\ldots .64$

I. Platypoda ................. 64

I. -Podophthalma ........... 64

Fam. 1. Ampullariadce........ 64

1. Pachystoma ............ 65

2. Asolene ................. 65

3. Marisa ................. 65

4. Ampullaria ............... 65

5. Pomella .................. 67

6. Lanistes .................. 68

7. Meladomus ........... 68

II. Edriophthalma ........ 68

A. Cryptocochlea ............. 68

Fąm. 2. Amphiperasida ...... 68

1. Amphiperas ............. 69

2. Calpurnus .............. 69

3. Ultimus ................ 69

4. Radius ................. 69

Fam. 3. Cypreade ........... 70

1. Cypræa ................. 71

2. Aricia .................. 72

3. Naria .................... 72

4. Trivia..................... 72

5. Luponia ................. 73

6. Cypræovula ........... 73

7. Erato ................... 73

Fam. 4 Pediculariade ......... 74

1. Pedicularia............... 74

Fam. 5. Aporrhaide........... 75

1. Aporrhais .............. 75

2. Struthiolaria ............ 76

3. Pelicaria................. 77

4. Trichotropis ............ 77

Verena (from p. 44).

5. Calcarella ................ 77

6. Sinusigera .............. 77 
B. Cochlea................... Page

A. Phaneropneumona ........ 78

Fam. 6. Cyclophorida ........ 78 a. Cyclotina.

1. Cyclotus ......

2. Pterocyclos

3. Opisthoporus ............. 79

4. Craspedopoma ........ 79

b. Aulopomina.

5. Aulopoma

6. Cyclophorus …..........

7. Leptopoma ............ 80

8. Alycæus ................ 80

9. Diplommatina ......... 80

c. Pupinina.

10. Megalomastoma........ 81

11. Cataulus................ 81

12. Pupinella...$\ldots \ldots \ldots \ldots .61$

13. Pupina ............... 81

14. Registoma ............ 81

15. Callia .................. 81

d. Licinina.

16. Jamaicia ................ 82

17. Licina................... 82

18. Choanopoma ........... 82

19. Adamsiella............. 82

e. Cyclostomina.

20. Lithidion ............ 82

21. Otopoma $\ldots \ldots \ldots \ldots \ldots . .63$

22. Cyclostomus ........... 83

23. Tudora ................ 83

24. Leonia ................ 83

25. Cistula ................ 83

26. Chondropoma ........ 83

f. Pomatianina.

27. Pomatias ............. 84

g. Realiana.

28. Liarea.................. 84

29. Realia.................... 84

30. Bourciera ............... 84

Fam. 7. Oligyrada ........... 84

1. Stoastoma ................ 84

2. Trochatella............. 85

3. Lucidella ............. 85

4. Helicina ................., 85

5. Alcadia ................ 86

Fam. 8. Proserpinida ... $\quad 86,188$

1. Proserpina ........ 86, 189

B. Pseudopneumona ........... 86

Fam. 9. Littorinida ........... 86

1. Assiminea .............. 87

2. Littorina................. 87
Page

3. Lithoglyphus ............ 89

4. Hydrobia .............. 90

5. Amnicola ............ 90

6. Nematura .............. 90

7. Risella .............. 90

8. Pagodus ................ 91

9. Ecbinella .............. 91

10. Modulus.................. 91

11. Fossar................... 91

Fam. 10. Lacunida .......... 92

1. Lacuna ............... 92

Fam. 11. Truncatellide ...... 93

1. Truncatella................ 94

2. Tonichia ................ 94

c. Teleobranchia .............. 95

Fam. 12. Planaxida .......... 95

a. Planaxina.

1. Planaxis ................ 95

2. Quoyia ................ 95

b. Litiopina.

3. Litiopa ............... 96

Fam. 13. Rissoade ........... 96

1. Rissoina ................ 96

2. Rissoa................. 97

3. Skenea ................ 98

Fam. 14. Cacida ............... 99

1. Cæcum .................. 100

2. Brochina ............ 101

Fam. 15. Melaniade............ 101

1. Melania ................. 101

2. Melanatria ............... 102

3. Pachycheilus ............ 102

4. Leptoxis .................. 102

5. Ceriphasia ............. 102

6. Gyrostoma .............. 103

7. Hemisinus ............. 103

8. Vibex ................... 103

9. Faunus ............... 103

10. Melanopsis............. 103

11. Clionella................. 104

12. Io ........................ 104

Fam. 16. Cerithiada.......... 105

a. Cerithiina.

1. Rhinoclavis ........... 105

2. Cerithium ................ 105

3. Bittium ................ 106

4. Tympanotomus ........ 106

5. Telescopium ........... 106

6. Pyrazus ................. 107

7. Lampania ................ jo 07 


\begin{abstract}
8. Potaruider Page
9. Cerithidea ................ 107

b. Tiphorina.

10. Triphoris ............. 108

Fam. 17. Turritellade ......... 109

1. Turritella ............... 109

2. Zaria .................... 110

3. Torculia ................ 110

4. Eglisia ................ 110

5. Mesalia .................. 111
\end{abstract}

Fam. 18, Barleeiada........... 111

1. Barleeia ................... 111

¿. Шуdrocæда .......... 111

lam. 19. Viviparide........... 111

1. Viviparus ............... $1 \mathrm{l} 2$

2. Rivulina ................. 114

3. Paludomus .............. 114

4. Tinalia ................. 114

5. Bithinia ..............., 114

b. Plocamobranchia .......... 115

Fam. 20. Calyptræade........ 115

i. Crepidulina.

1. Crepidula .............. 115

2. Garnotia................ 117

b. Galerina.

3. Galerus .................. 117

4. Trochita ................. 118

5. Crucibulum ........... 118

$\therefore$ Calyptraina.

6. Calyptra............... 119

l'am. 21. Capulidee ........... 119

1. Capulus ................ 119

2. Hipponyx $\ldots \ldots \ldots \ldots \ldots, 121$

3. Amalthea ............ 121

Fam. 22. Vanicoroide ........ 121

1. Vanicoro............... 1:2

๘. Streptobranchia............ 1222

Fam. 23. Valvatida ........... 122

1. Valvata ............... 122

III. Opisophthalma....... 123

Fam. 24. Aciculadre ........... 123

1. Acicula ................ 124

2. Geomelania ........... 124

Fam. 25. Rissoellida ........, 124

1. Rissoella................, l:4t

2. Macgillivrayia ........ 125
II. Protopoda ............. 126

Fam. 1. Vermetida ........... 126

a. Vermetina.

1. Siphonium ............. 126

2. Vermetus ............... 126

3. Spiroglyphus ........... 127

4. Bivonia ............... 127

5. Serpuloides ........... 127

6. Lementina .............. 127

7. Cladopoda .............. 127

b. Siliquariana.

8. Siliquaria ............ l les

III. Leptopoda ............. liss

Fam. 1. Strombide ........... 128

a. Strombina.

1. Strombus ............. 12

2. Pterocera .............. 130

3. Fusus .................. 130

b. Seraphina.

4. Seraphys................ 130

Fam. 2. Phorida ............. 130

1. Phorus ................ 130

2. Onustus ................ 131

IV. Heteropoda ........... 131

Fam. 1. Pterotrachtida ..... 131

1. Anops ................. 1:31

2. Pterotrachea ............ 13i

3. Firoloida ............... 1;32

4. Cerophor'a .............. lis

5. Cardiapoda............. 132

f. Carinaria ................ 132

Tum. 2. Atlantide.............. 133

1. Oxygyrus $\ldots . . . \ldots . . . .133$

2. Atlanta ................ 134

3 Steira ................... 134

Order II. Scutibranchiata 135

Synopsis of Suborders ........ 135

I. Riphidoglossa .......... 135

Suborder I. Scutibranchi a 136

Fam. 1. Neritinide .........., 136

1. Nerita.................. 136

2. Puperita ................ 137

3. Neritella............... 137

4. Catillus ................ 139

Fam. 2. Rotellade ........... 139

1, Rotella ................ 140

2. Photina .............., 141

3. Isanda ................ 141

1. Camaitia ................ I11 


\begin{tabular}{|c|c|}
\hline Fom 3 Turbinide Page & $\begin{array}{r}\text { Page } \\
156\end{array}$ \\
\hline Fam. 3. Turbinide.......... .141 & 26. Valvatella \\
\hline 1. Sarmaticus..... & d. Canthiridina. \\
\hline 2. Turbo.................... 142 & 27. Canthiridus $\ldots . . . \ldots \ldots . .157$ \\
\hline 3. Marmorostoma ......... 143 & 28. Elenchus ............ 157 \\
\hline 4. Amyxa $\ldots \ldots \ldots \ldots \ldots \ldots, 143$ & 29. Bankiva ................. I5 \\
\hline 5. Modelia ................. 143 & 30. Aradasia,$\ldots \ldots \ldots \ldots \ldots \ldots$ is \\
\hline 6. Callopoma .............. 143 & 31. Otavia \\
\hline $\begin{array}{l}\text { 7. Ninella ................ } 143 \\
\text { 8. Collonia ................. } 143\end{array}$ & Fam. 6. Stomatellidre ........ 158 \\
\hline Imperatorina. & 1. Stomatella ............... ] \\
\hline 9. U & 2. Stomax \\
\hline 10. $\mathrm{Cs}$ & …........ 15 \\
\hline$\ldots 1$ & 5. Broderipia ................ 16 \\
\hline 12. Guildfordia & \\
\hline
\end{tabular}

S.O.II. Schismatobranchia 160 Fam. 7. Scissurellide ......... 160 1. Scissurella .............. 160

Fam. 8. Haliotide ........... 161

1. Haliotis ................. 161

2. Parollus.................. 162

3. Teinotis ................. 162

S.O. III. Dicranobranchia 162

Fam. 9. Fissurellidce........... 162

1. Scutus ................. 162

2. Tugalia ................. 163

3. Emarginula ........... 163

4. Hemitoma ............... 164

5. Clypidina ............... 164

6. Deridobranchus .......... 164

7. Puncturella ........... 164

8. Rimula .................. 165

9. Macroschisma ........... 165

10. Fissurella ................ 165

11. Clypidella .............. 166

12. Capiluna ................. 166

13. Fissurellidxa ............... 166

14. Lucapina ............... 166

15. Pupillia ................ 167

II. Iteteroglossa ........... 167 S.O. IV. Cirrobranchia ... 167 Fam. 10. Dentaliade ......... 167

1. Dentalium ............. 168

2. Entalis ............... 168

S.O. V. Cervicobranchia . 169

Fam. 11. Tecturida ............ 169

1. Nacella .................. 169

2. Tectura .................. 169

3. Scurria ................. 171 


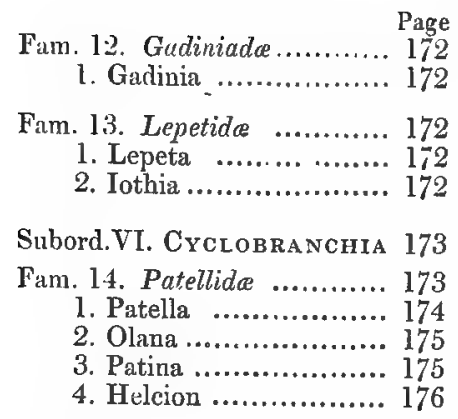

S.O. VII. Polyplacophora 176

Fam. 15. Chitonide ............ 177

1. Chiton ................. 180

2. Enoplochiton........... 181

3. Radsia ................. 181

4. Callochiton ............. 181

5. Ischnochiton ............. 182

6. Leptochiton ............ 182

7. Lorica.................. 183

8. Schizochiton .............. 183

9. Acanthopleura .......... 183

10. Maugeria .............. 183

11. Corephium.............. 184

12. Onythochiton ......... 184

13. Molpalia................. 184

14. Tonicia ................. 185

15. Fannyia ................. 185

16. Katharina ............. 185

17. Cryptochiton ..........., 185

18. Plaxiphora .............. 186

19. Hanleya ................ 186

20. Acanthochetes ........ 186

21. Chitonellus ........... 187

22. Amicula ............... 187

23. Cryptoconchus ......... 188

Subord.I*.Pseudobranchia 188

Fam. 1*. Proserpinade ...... 188

1. Proserpina ............... 189

2. Ceres ................... 189

S.C.II. Hetgrobranchiata 191

Ord.III.Pleurobranchiata 191

Fam. 1. Philinide.............. 191

1. ? Gasteropteron ......... 191

2. Posterobranchra ...... 192

3. Doridium ............... 192

4. Philine .................. ] 92

5. Hirundella .............. 193

6. Cryptophthalmus ...... 193
Page

7. Xanthonella ........... 194

8. Glauconella ........... 194

9. Scaphander ........... 194

Fam. 2. Amphisphyrada ..... 194

1. Amphisphyra............ 194

Fam. 3. Bullinada ............ 195

1. Bullina ................. 195

Fam. 4. Bullidee .............. 196

1. Akera,$\ldots . . . . . . . . . . . . . .196$

2. Bulla .................. 196

3. Haminea .............. 197

Fam. 5. Amplustrides ........ 197

1. Amplustrum ........... 197

2. Bullinula ............. 197

3. Hydatina ................ 197

Fam. 6. Aplysiade ........... 198

1. Dolabella .............. 198

2. Dolabrifera.............. 199

3. Aplysia ................ 199

4. Notarchus ............. 201)

5. Bursatella ................ 200

6. Aclesia .................... 200

Fam. 7. Lophocercidse ......... 201

1. Lophocercus ........... 201

2. Lobiger ................. 201

Fam. 8. Pleurobranchide..... 201

1. Pleurobranchus ......... 202

2. Susania .................. 202

3. Oscanius................. 203

4. Neda ..................... 203

5. Pleurobranchan......... 203

Fam. 9. Tylodinadce (addit.)... 203

Fam. 10. Umbrelladce ......... 204

1. Umbrella ............... 204

Fam. 11. Runcinada........... 204

1. Runcina ................ 205

Ord.IV.Gymnobranchitata 205

Subord. I. Pygobranchia... 206

Fam. 1. Onchidorida ......... 206

1. Onchidoris .............. 207

2. Acanthodoris ............ 207

3. Villiersia .............. 207

Fam. 2. Doridida ............. 208

1. Glossodoris ........... 208

2. Chromodoris .......... 208 


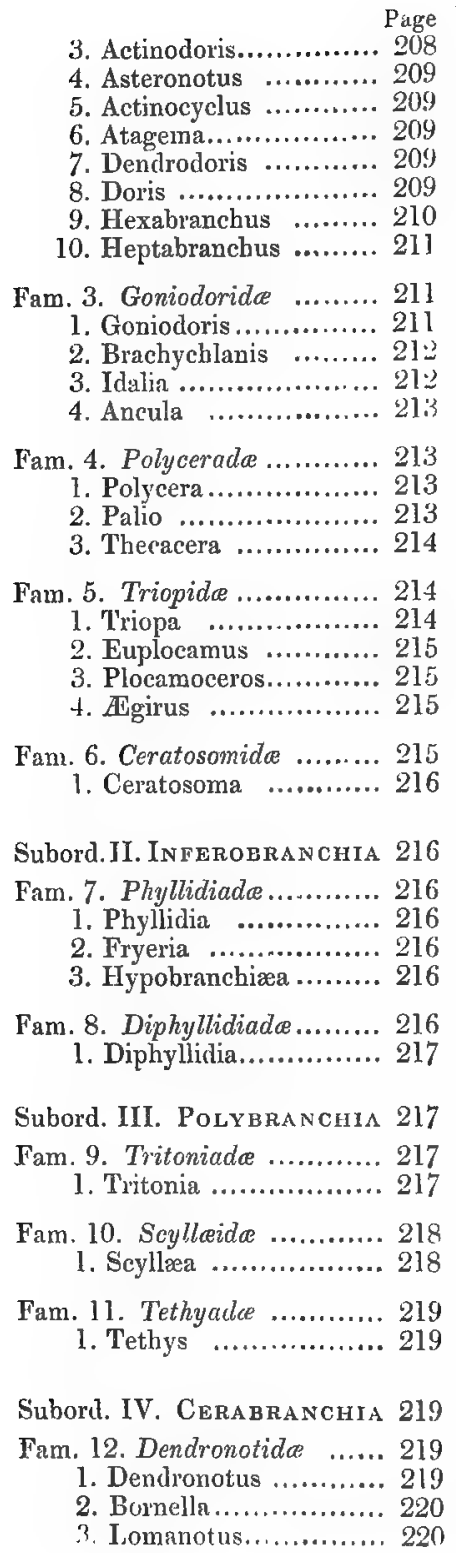

Fram. 13. Proctonotide....

1. Proctonotus ........... 220

2. Janus ................... 221

Fam. 1. Heroide............, 221

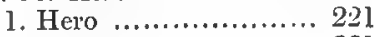

2. ? Gellina ................ 221

3. ? Nerea ............... 222

Fam. 15. Dotonidee ........... 222

1. Doto .................. 222

2. Melibe ................. 222

Fum. 16. Glaucide ........... 222

1. Glauctis ...................

Fam. 17. Eolidide ............ 223

1. Calma ................... $22: 3$

2. Flabellina ............. 223

3. Facelina ................ 223

4. Coryphella.............. 224

5. Favorinus .............. 224

6. Phidiana............... 224

7. Eolidia ................ 224

8. Cuthona.................... 20

9. Cavolina.................. 225

10. Galvina ................. 236 6

11. Tergipes .............. 226

12. Embletonia ........... 226

13. Calliopra...$\quad$..........

Fam. 18. Fionide ............. 2:

1. Fiona ................... 227

Fan. 19. Hermeride ............ 2.27

1. Hermæa ................... 227

2. Stiliger $\ldots \ldots \ldots \ldots \ldots \ldots$.

3. Alderia .....................

Subord. V. Placonranchia 228

Fam. 20. Elysiadce ........... $22 \%$

1. Elysia.....................

2. Placobranchus ........ 2.?

Subord.VI. Pelligranchia 229

Fam. 21. Limapontiada ..... 229?

1. Limapontia ......... 22!)

2. Aetæonia ............ 229

3. Ietis .................. 230

4. Fucola ................. 2:30

5. Pelta ...................., 230

lian. 22. Phyllirrhoide ..... 230 1. Phyllirrhoë ...........230 


\title{
SYSTEMATIC ARRANGEMENT
}

\author{
OF

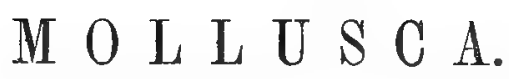

\section{Subkingdom MOLLUSCA.}

Animal soft; flesh destitute both of a bony skeleton supporting jointed limbs, and of a hard, ringed skin; covered with a muscular coat called the Mantle endued with a glairy humour, and generally furnished with one or two Iateral calcareous envelopes called Sriells, which are secreted by this coat for the protection of the body and of the more vital organs of the animal. The body is generally elongate, walking on a single central disk or foot, and provided with one or more pairs of organs on the head and sides. The nervous system (which furnishes the most distinctive character of the larger group of the Animal Kingdom) merely consists of a certain number of medullary masses distributed to different parts of the body, one of the masses being placed over the gullet and surrounding it like a collar.

Linnæus refers all the animals inhabiting shells to five genera, viz. Limax, Ascidia, Anomia, Clio, and Sepia. These genera may be regarded as the types of the classes proposed by Cavier. Poli had, before his time, considered three of them as Orders, under the names of Mollusca Reptantia, Subsilientia, and Brachiata.

\section{Synopsis of Classes.}

\section{A. Pedifera. Crawling on a foot placed under the body.}

I. Gasteropoda (Gasteropods or Univalves). Head distinct, with eyes and tentacles; body usually protected by a conical, more or less spiral shell, often furnished with an operculum.

II. Conchifera (Conchifers or Bivalves). Head indistinct; mouth placed between the gills; they and the body enclosed between the two leaves of the mantle, which are covered by two shelly valves united above by a ligament. 


\section{B. Apoda. Foot none, or very rudimentary.}

III. BraChIOPODA (Brachiopods or Lamp-shells). Mouth placed at the base of two spirally-twisted ciliated arms between the two leaves of the mantle, which are covered with two separate shelly valves : they live attached to other marine bodies.

IV. Pteropoda (Pteropods). Head prominent, with one or rarely two pairs of fins on the side of the neck, by means of which they swim on the ocean; body often covered with a thin conoidal shell.

V. Cephalopoda (Cephalopods). Head distinct, large, with eight or ten or more arms, by which they walk head downwards.

A. Pedifera, Gray. The adult animal fumished with a more or less distinct foot placed under the body for crawling on the ground or surface of the water.

\section{Class I. GASTEROPODA, Cuvier.}

Animal having a distinct head furnished with eyes and tentacles, and usually protected by one or two unequal-sized valves, the largest being conical, spiral, and enclosing the greater part of the body.

\section{Synopsis of Orders.}

Subclass I. Gills comb-like, formed of one or two series of lamellee under the mantle on the back of the neck, or rarely round its edges. Adult and larva shell-bearing; larva furnished with deciduous cephalic fins. Unisexual or hermaphrodite and selfimpregnating. Ctenobranchiata, Gray, 1840. Prosthobranchia (or Prosobranches), M.-Edwards, 1848.

Order I. Pectinibranchiata. Gills comb-like, formed of one (or rarely of two) longitudinal series of laminæe on the left side of the mantle over the back of the neck. Animal unisexual. Shell spiral.

Order II. Scutibranchiata. Gills consisting of two series of lamellæe, forming one or two series over the back of the neck or under the edge of the mantle round the foot. Animal hermaphrodite, self-impregnating. Shell conical, spiral or symmetrical. Rectum often traversing the heart.

Subclass II. Respiratory organs variously formed; gills exposed or only stightly covered by a fold of the mantle, or in the form of a closed lung-like cavity. Hermaphrodite, with reciprocal impregnation. Heterobranchiata, Gray, 1840. Opisthobranchia (or Opistobranches), M.-Edw. 1848.

Order III. Pleurobranchiata. Gills forming a tuft on the side under a fold of the mantle. Animal hermaphrodite, with reci- 
procal impregnation. Shell spiral. Adult and larva shell-bearing; larva with deciduous cephalic fins.

Order IV. Grmnobranchiata. Gills exposed or contractile into a cavity on the surface of the mantle. Adult shell-less; larva shellbearing, with deciduous cephalic fins. Animal hermaphrodite, with reciprocal impregnation.

Order V. Pneumobranchiata. Respiring free air in a closed chamber lined with pulmonie vessels. Adult and larva shellbearing; larva shaped like the parent, without cephalic fins.

\section{Subclass I. CTENOBRANCHIATA, Gray.}

Gills comb-like, formed of one or two series of plates (or some ramified vessels) on the inner surface of the mantle (or rarely round its edge). Gill-cavity open. Mantle free from the back of the neck.

Adult and larva shell-bearing; larva furnished with deciduous ciliated fins on the side of the head. Unisexual or hermaphrodite and self-impregnating.

\section{Order I. Pectinibranchiata, Cuvier.}

Gills comb-like, formed of one or rarely two longitudinal series of lamellæ (or very rarely some branched vessels) on the left side of the mantle over the back of the neck. Gill-cavity open, the mantle edge being free from the back of the neck. Animal unisexual. Shell spiral. Operculum usually distinct.

\section{Synopsis of Suborders.}

I. Toxifera. Head small; proboscis retractile under the base of the tentacles. Teeth elongate, subulate, implanted in the fleshy proboscis (figs. 2, 3).

II. Proboscinifera. Head small; proboscis retractile under the base of the tentacles. Teeth variable, in an elongated cartilaginous tongue-membrane (figs. 1, 6, 7, \&c.).

III. Rostrifera. Head produced into a rostrum, with the tentacles on the side of its base. Teeth in seven longitudinal series $3 \cdot 1 \cdot 3$, in a cartilaginous tongue-membrane (fig. 1).

Fig. 1.-Lingual membrane and teeth of Buccinum undatum.

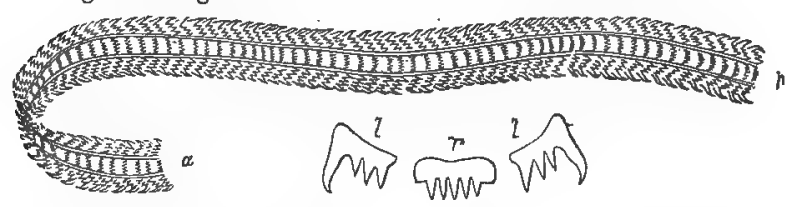

$u$, the front end of lingual band. $\quad r$, central teeth. $l$, lateral teeth.

II 2 


\section{Suborder I. Toxmera, Gray.}

Head small, with a retractile proboscis, (when retracted) hidden in the body. Tentacles close together at the base or on the side of a funnel-shaped veil surrounding the mouth. Teeth elongate, subulate, in two series, implanted in the fleshy proboscis (fig. 2). Eyes sessile on the outer side, or near or on the end of the tentacles.

Fig. 2.

\section{A. Mouth surrounded by a rostrum-like veil} over the base of the proboseis.

\section{Fam. I. CONUSID $\mathbb{E}$.}

Animal. Mouth surrounded by a funnelshaped, rostrum-like veil, slit above. Tentacles on the side of the veil. Eyes on short tubercles adnate to the outer side of the tentacles, and more or less distant from the base. Siphon of mantle and canal of shell recurved. Mantle entire. Teeth with a more or less swollen base and somewhat twisted, perforated and barbed at the tip (fig. 2).

Shell obconic; whorls compressed; aperture linear. Operculum horny, annular; nucleus apical, rarely absent.

The head of Conus textilis produced into an elongated funnel-shaped veil; proboscis retractile. Teeth in two series, red; upper ones in two parallel irregular lines which diverge from one another below; when retracted they are bent from the mouth of the proboscis.
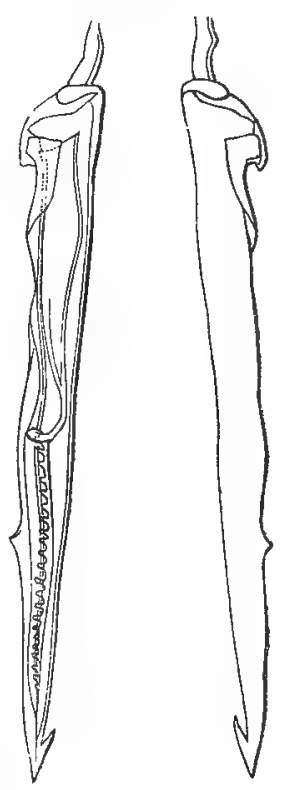

\section{a. Aperture of shell linear, narrow. Operculum distinct.}

\section{Conus.}

Veil of the mouth simple at the end. Operculum thick, flat above, ovate, linear, apex acute, front or inner side straight.

1. C. bandanus, Fig. Moll. t. 11.f. 8, t. 10. f. 7, t. 83. f. 2 .

2. C. mediterraneus, Fig. Moll.t. 83. f. 4.

3. C. acuminatus, Fig. Moll. t. 83. f. 3.

4. C. - Fig. Moll. t. 81 a. f. 6 .

5. C. pulicarius, Fig. Moll. t. 10. f. 8. Operculum, Adams, Gen. Moll. t. 26. f. 1 a.

6. C. marmoreus, Fig. Moll. t. 10. f. 5.

7. C. hebræus, Fig. Moll. t. 10. f. 4.

8. C. figulinus, Fig. Moll. t. 10. f. 3.

9. C. Miles, Fig. Moll. t. 10. f. 2.

10. C. betulinus, Fig. Moll. t. 12. f. 1 . 
11. C. lividus, Fig. Moll. t. 12. f. 3 .

12. C. tæniatus, Fig. Moll. t. 12. f. 5.

13. C. arenatus, Fig. Moll. t. 12. f. 8, 9.

14. C. -. Strombus, Fig. Moll. t. 11. f. 1, 2.

15. C. raphanus, Fig. Moll. t. 11. f. 3.

16. C.? rusticus, Fig. Moll. t. 11. f. 4.

17. C. sanguinolentus, Fig. Moll. t. 11. f. 5.

18. C. (Cylinder) textilis, Fig. Moll. t. 10. f. 1 .

\section{Tuliparia.}

Veil of mouth fringed at the end. Teeth hastate. Operculum ovate, horny.-Adams, Gen. Moll. t. 26 . f. 2.

1. T. Tulipa, Fig. Moll. t. 12. f. 2.

2. T. striata, Fig. Moll. t. 10. f. 6 .

\section{b. Aperture of shell wide. Operculum none.}

\section{Rollus.}

Veil —? Operculum none. Shell subcylindrical, ventricose. Mouth large, wide. Spire short.

1. R. geographicus.

B. Mouth simple, not forming a produced rostrum-like veil over the base of the proboscis.

Farn. II. ACUSID 2 .

Mouth exposed. Tentacles very small, close together on the side of the mouth. Eyes none or very small, near or on the top of the very small tentacles. Mantle enclosed, entire. Siphon elongate, recurved. Teeth "elongate, swollen at the base, and furnished with a denticulated keeled line as in Conus." Foot small. Shell turrited, smooth; spire very long. Mouth ovate; inner lip rather concave; outer thin. Canal short, recurved. Operculum annular.

The tentacles of Acusida are exceedingly minute, placed on the upper edge of the inflexed trunk; in some species they are so small as not to be seen; some have the eyes on the tips of the small tentacles, and others have no visible eyes. The male organ is very filiform, very long, as long as two whorls of the shell. Foot small, folded across when contracted. Head rounded. Mantle with a very long, slender, breathing siphon. Operculum horny, ovate, nearly as large as the mouth of the shell, with a rather thickened rib on its inner side. The inner lip of the shell is generally absorbed and concave; in a few species only, as in Acus Cerithina, is it thickened and elevated.

The species of Acus live only below low-water mark.-Adams.

The trunk of the genus Acus is represented as short and campanulate by $Q u o y$, t. 36. f. 17; but in other figures, as in fig. 19, the muzzle is represented as produced. That the genus has a trunk, and not a muzzle, is proved by fig. 31 , where the anatomy is given. In the same plate, Murex roseus, t. 36 . f. 11 , and $M$. ricinuloides, 
t. 36. f. 15, are represented as having a corrugated muzzle and lateral tentacula, as if they had no trunk; they differ in this respect from the other figures of the same species at fig. 13, where the tentacles are properly represented as close together at their base.

\section{Acus.}

Tentacles small. Suture of shell simple. Operculum ovate; nucleus apical.

1. A. maculatus, t. 85 a.f.8, t. 99. f. 1 ; Adams, Gen.Moll. t. 24. f.1. 2. A. subulatus, t. 99. f. 3 ; Adams, Gen. Moll. t. 24. f. 2.

Tentacles of Acus maculatus very small, short, cylindrical, nearly close, with verysmall eyes at the apex. Mantle simple. Siphon broad, rather short. Foot folded down on each side in front when contracted. Proboscis elongate, thick, entirely retractile. Lingual membrane and teeth —? Operculum ovate, trigonal, nearly flat, with a subcentral longitudinal ridge, brown; apex subacute; nucleus apical.

The mantle of Acus maculatus is enclosed. Siphons elongate, conical, when contractile spirally curved. Tentacles very small, nearly close together at their base, short, cylindrical, blunt, with the eyes at their tips, without any veil. Proboscis very long, cylindrical, with a large longitudinal mouth. Lingual membrane and teeth - ?

\section{Subula.}

Tentacles and eyes none. Suture of shell simple. Operculum ovate. Nucleus apical.

1. S. ? ? anatomy, t. 99. f. 2 .

2. S. dimidiata, t. 99 . f. 4 .

3. S. strigilata, t. $85 a$. f. 9 .

Foot of Subula dimidiata moderate; folded across. Operculum horny, lanceolate. Head indistinct; only an aperture for the emission of the pruboscis. Tentacles none. Eyes none. Mantle enclosed. Siphon elongate, spirally twisted when retracted into the shell.

\section{Lerodomus.}

Tentacles small. Operculum ovate. Suture of shell callous, like Bullia, but foot small.

1. L. cæruleus.

Foot of Leiodomus cerulescens moderate, folded longitudinally in front. Mantle enclosed. Siphon rather elongate, crenulated on the lower edge. Tentacles very small, very short, subcylindrical, with the eyes on their tips, placed on each side of the contracted cavity for the emission of the proboscis, without any veil. Proboscis elongate. Lingual membrane ___ ? Male organ elongate, subcylindrical, on hinder part of right side. Operculum ovate, much smaller than aperture of shell, blunt at each end, annular, thick ; nucleus subanterior, on front of inner side.

According to the observations of $\mathrm{M}$. Morch, Leiodomus cinereus 
has two series of elongated subulate teeth, swollen at the base, and furnished with a denticulated keeled line, like Conus.

4. Dorsanum.

Shell ovate; suture simple; outer lip simple, acute. Operculum - ?

1. D. politum, t. 24 . f. 12,13 .

\section{Fam. III. PLEUROTOMID无.}

Animal. Mouth exposed. Tentacles close together at the base of the mouth. Ejes adnate to the outer side of the tentacles near the base. Mantle enclosed, with a slit in the hinder part of the outer side. Siphon produced. Teeth simple; base rather enlarged (fig. 3).

Shell spiral, fusiform; whorls roundish. Aperture ovate; outer lip with notch or groove behind. Operculum horny, annular, rarely wanting.

The mantle of the specimen in spirits is grooved as if with plaits on the outer lip.

Fig. 3.

Teeth of Mangelia.

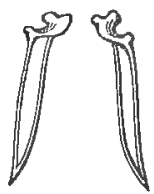

a. Clavatulina. Operculum semi-ovate, annular; nucleus in the centre of the straight front edge (fig. 4).

\section{Clavatula.}

Shell turrited, spire elongate, canal short.

1. C. bimarginata.

2. C. imperialis, Adams, Gen.Moll. t. 10. f. 5, operculum only.

3. C. muricata.

2. Tomella.

Fig. 4.

Shell fusiform, canal elongate, inner lip callous near suture.

1. T. lineata, Swains. Pleurotoma 1., Lamk.; Adams, Gen. Moll. t. 10. f. 5, operculum (fig. 4).

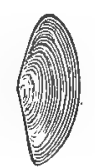

b. Pleurotomina. Operculum ovate, acute; nucleus apical (fig. 5).

\section{Pleurotoma.}

Shell fusiform, canal elongate, produced; outer lip with a fissure near the suture. Operculum ovate-lanceolate, flat, front side straight.

1. P. babylonica, Fig. Moll. t. y0. f. 3, t. 90. f. 4 .

2. P. virgo, t. 90 . f. 1.

3. P. oxytropis, Lam/.

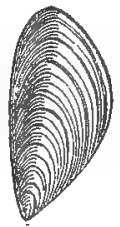


In $P$. babylonica the eye-peduncles are thick, cylindrical, annulated, with large black eyes at the end. The tentacles are short, subulate, blunt, on the outer side of the tip of the eye-peduncle. The operculum ovate, acute, subannular, with an apical nuclens (fig. 5).

\section{Drillia.}

Shell turrited; mouth ovate; canal short. Operculum ovate, acute; nucleus apical. Eyes on upper part of tentacula.

1. D. —, t. 84 a. f. 2.

2. D.? echinata, t. 91 . f. 4 .

3. D. cagayanensis, Adams, Gen. Moll. t. 10. f. 2.

4. D. alabaster, Adams, Gen. Moll. t. 10. f. $2 a$, $b$, operculum only.

5. D. maculata.

6. D. flavidula.

7. D. funiculata.

8. D. Maravignæ.

\section{BeLA.}

Shell fusiform and subturrited; whorls waved or smooth; outer lip simple, or with a very slight sinus at the hinder end near the suture, Operculum ovate, acute. Eyes on the upper part of the tentacles.

1. B. Turricula, Forbes \& Hanley, B. M. t. T.T. f. 2.

2. B. septangularis, Forbes \& Hanley, B. M. t. T.T. f. 3.

3. B. rufa, Forbes \& Hanley, B. M. t. T.T. f. 4.

4. B. nobilis, Adams, Gen. Moll, t. 10. f. $3 a, b$, operculum only.

\section{c. Defranciina. Operculum none.}

\section{Defrancia.}

Shell fusiform or subturrited; mouth ovate; canal short; outer lip slightly nicked behind.

"Tentacula setaceous. Eyes subpedicelled. Foot depressed, two-lobed and horned in front. Operculum none. D. lineata." Lovén.

1. D. multilineata, Fig. Moll. t. 90.f. 2, t. 105.f.5.

2. D. Lefroyi, Forbes \& Hanley, B. M. t. R.R. f. 1 .

3. D. brachystoma, Forbes $\&$ Hanley, B.M. t. R.R. f. 2 .

4. D. teres, Forbes \& Hanley, B.M. t. R.R. f. 3.

5. D. costata, Forbes \& Hanley, B.M.t. R.R. f. 4.

6. D. attenuata, Forbes \& Hanley, B.M. t. R.R. f. 5.

7. D. linearis, Forbes \& Hanley, B. M. t. R.R. f. 6 .

8. D. nebula, Forbes \& Hanley, B. M. t. R.R. f. 7 ; Adams, Gen. Moll. t. 10. f. 10.

9. D. gracilis, Forbes \& Hanley, B. M. t. R.R. f. 8 . 
d. Operculum and animal unknown.

\section{?7. AnNa.}

Shell fusiform; mouth ovate; outer lip rather thickened, crenate. "Operculum horny."-Philippi. Teeth — ?

1. A. Massena, Phil. Moll. Sicil. ii. 188. t. 27. f. 5.

\section{? 8. Melatoma.}

Shell fusiform; mouth elongate, linear; outer lip notched at the suture; canal short. Operculum —? Teeth —- ?

1. M. suleata, Swains.

\section{? 9. Conopleura.}

Shell obconic; whorls compressed; mouth linear. Operculum ? Animal - ?

1. C. striata, Hinds.

\section{? 10. Daphnella.}

Shell fusiform, thin; mouth elongate, oblong, slightly channeled in front; outer lip acute. Operculum —?

1. D. marmorata.

2. D. ornata, Adams, Gen. Moll. t. 10. f. 8, shell only.

Suborder II. Proboscidifera, Gray.

Head small, with an elongated retractile (long exsertile) proboscis, when retracted hidden in the body. Tentacles close together at the base or united by a veil over the base of the proboscis. Teeth in 1,3 , or 7 series on the surface of a linear elongate horny membrane. Gills in two series with some mucous filaments. Eyes sessile, generally on the outer side near the base of the tentacles, but sometimes at the tip or on the head behind their base. Carnivorous; eating living mollusca and other animals; often boring round holes in the shell to arrive at the living animal.

I. Edriophthalma. Eyes on the outer side of the base of the tentacles.

A. Hamiglossa. Teeth in three series; central fixed, lateral versatile.

B. Odontoglossa. Teeth in three series; central and lateral fixed, transverse.

C. Rachiglossa. Teeth in a single longitudinal series.

D. Trenioglossa. Teeth in seven series; the central and inner lateral fixed, two outer lateral mobile.

E. Ptenoglossa. Teeth in numerous longitudinal series.

II. Iniophthalma. Eyes sessile, between and behind the tentacles.

A. Ptenoglossa. Teeth in numerous series.

B. Tanioglossa. Teeth in seven series; the two outer lateral mobile.

C. Gymnoglossa. Teeth none. 
Tribe I. Edriophthalma, Gray.

Eyes sessile or nearly so, on the outer side of the base of the tentacles.

A. Hamiglossa, Gray. Teeth in three series $1 \cdot 1 \cdot 1$, the central broad, fixed; lateral, versatile. Mantle and shell siphonal. Operculum annular. Shell spiral, pillarless, smooth, or only slightly grooved in front.

a. Hamiglossa vera. The lateral teeth hamate, curved. Shell external (figs. $1 \& 6-9$ ).

\footnotetext{
* Foot moderate, contractile into the shell, not cross-grooved in front, and not producing a polished coat on the shell.
}

\section{Fam. I. CASSIDULIDA, Gray.}

Head elongate, conical, produced. Tentacles very small, near the end of the head. Siphon of mantle and canal of shell elongate, straight. Foot simple in front. Shell spiral; pillar smooth. Operculum horny, annular, sometimes deficient.

\section{a. Operculum horny, ovate, acute.}

\section{Cassidulus.}

Shell pear-shaped; spire short; mouth ovate, elongate, large, narrowed in front into a broad, straight, open canal; outer lip simple; inner lip smooth. Operculum ovate, acute, rather small.

1. C. Melongena, t. 88. f. 1. Fig. 6.-Teeth of Cassidulus Morio.

2. C. galeodes, t. 266 . f. 1 .

3. C. Cochlidium, t. 266 .f. 2.

4. C. Vespertilio.

5. C. Colosseus.

6. C. Morio, teeth (fig. 6).

Head of Cassidulusnodosus rostriform, conical, annulated,

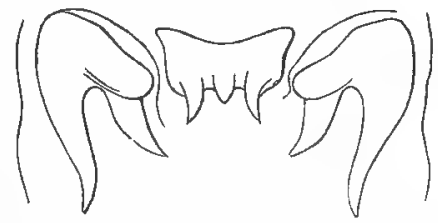
with two very small tentacles close together at the base of the tip, with the eyes on their external base. Proboscis small, conical, perfectly retractile. Lingual membrane very narrow, elongate. Teeth $1 \cdot 1 \cdot 1$; central elongate, narrow, with one small central and one very long, conical, lateral denticle; lateral teeth with a knee, base simple. Operculum ovate, acute, nucleus apical, acute.

The head of Cassidulus Vespertilio conical, produced. Tentacles very small, nearly close together at the end of the head. Eyes small on the outer side and rather below their base. Proboscis exceedingly long, completely retractile, cylindrical, rigid, ringed. Teeth $1 \cdot 1 \cdot 1$; central elongate, rather narrow, with three denticles in front, the central smallest; lateral hamate, with a strong basal tooth.

Cassidulus Melongena is found on the mud-banks of Jamaica, and C. patulus on those of Panama; they are eaten in both localities. - Adams. 


\section{Fulgur.}

Shell like Cassidulus, but spire shorter; last whorl very large; mouth very open. Teeth - ? Operculum very small ovate or claw-shaped.

1. F. canaliculata.

2. F. Carica.

\section{b. Operculum none.}

\section{Cochlidium.}

Shell very like Cassidulus, but operculum none. Head elongate conical, like a suout, with a very long, exsertile proboscis. Tentacula very small, on the side of the mouth. Eyes small, on outer side of their base. Male organ large. Foot ovate, truncated in front. Teeth central, 3-toothed, lateral hooked, versatile.

1. C. Tuba. Pyrula tuba, Eydoux, Voy. Bonite, t. 43.

Fam. II. MURICID $\approx$, Fleming.

Head small, truncated. Tentacles moderate. Mantle enclosed. Operculum horny, annular; nucleus apical or subapical, just within the apex. Shell external; pillar smooth.

A. Siphon produced. Canal of shell produced.

a. Muricina. Shell with three or more varices, often branched; inner lip smooth; outer lip often with a tooth-like process in front. Operculum ovate; nucleus subapical, within the apex (fig. 7).

* Hinder part of the edge of the mantle and lip of shell simple, or with a sutural groove.

\section{Murex, Lamk.}

Shell ovate; spire short, with three or more rounded or spinose varices on each whorl; mouth ovate ; canal elongate, tubular, spinose externally.

$$
+ \text { Varices distinct, spinose. }
$$

Fig. 7.

1. M. tenuispinus, t. 6 . f. 2 .

2. M. Brandaris, t. 6. f. 3 o, t. 7 . f. $1,2$.

3. M. Spirilla.

十† Varices rudimentary, unarmed. Pyrenella.

\section{Chicoreus.}

Shell ovate; spire acute, with three or more often branched or spinose varices on each whorl; mouth ovate; canal moderate, bent up to the right. 
1. C. inflatus, t. 84 .

2. C. erinaceus, t. 89. f. 6 ; Forbes \& Hanley, B. M. t. T.T.f.1.

3. C. palma-rosæ, t. 7. f. 6 .

4. C. zealandicus, t. 7. f. 3.

5. C. octonus, t. 7. f. 4.

6. C. Trunculus, t. 6. f. 1 t, t. 89. f. 7.

7. C. ricinuloides, t. 7. f. 5 .

Sometimes, instead of the processes of the varices being branched, they are short, conical and simple; at others the tubercles between the varices are produced into varices, when the shell has six instead of three varices on each whorl, which proves that these tubercles may be considered as abortive varices.

\section{Trophon.}

Shell ovate; spire short, with numerous lamellar varices on each whorl; mouth ovate; canal moderate, open, rather bent to the right. Eyes on short tubercles.

1. T. patagonicum, t. 89 . f. 2 .

2. T. Bamfium, Forbes \& Hanley, B. M. t. S.S. f. 3.

3. T. echinatum, Forbes \& Hanley, B. M. t. S.S. f. 4.

4. T. Barvicense, Forbes \& Hanley, B. M. t. S.S. f. 5.

** Hinder edge of mantle and outer lip with a tubular canal.

\section{Typhis.}

Shell ovate; spire short, with three or more thin varices on each whorl, and with a tubular canal at the hinder part of the outer lip; anterior canal short, bent up, tubular.

1. T. pungens.

b. Colusina. Parices of shell rudimentary or none. Inner lip smooth. Operculum ovate, acute; nucleus apical (fig. 8).

\section{Colus.}

Animal red. Operculum ovate, acute. Shell fusiform; spire elongate, conic; canal more or less elongate, straight; inner lip smooth.

1. C. multicarinatus, t, 90. f. 2 .

2. C. australis, t. 9. f. 3 .

3. C. ? ?. 9 . f. 2 .

4. C. raphanus, t. 9. f. 1 .

5. C. dilatatus, t. 9. f. 5 .

6. C. polygonoides.

Fig. 8.

Operculum of Colus.

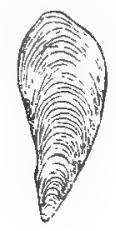

6. Clavelia.

Shell fusiform or turbinate; last whorl large, irregularly enveloping the rest; inner lip smooth. Operculum acute. Teeth - ? 1. C. serotina. 
7. Chrysodomus.

Shellovate, fusiform; spire conic; whorls smooth, without any rudimentary varices; canal very short, straight. Operculum ovate, acute. Animal olive.
Fig. 9.-Teeth of Chrys. antiques.

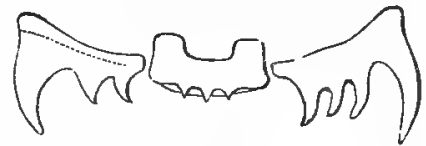

1. C. antiquus, t. 92. f. 1, t. 89. f. 8. Teeth (fig. 9).

2. C. propinquus, Forbes \& Hanley, B. M. t. S.S. f. 1.

3. C. Islandicus, Forbes \& Hanley, B. M. t. S.S. f. 2.

4. C. bullosus.

5. C. contrarius.

6. C. Turtoni, Forbes \& Hanley, B. $M$.

\section{Strombella.}

Shell ovate, fusiform; whorls smooth; canal very short; outer lip .expanded. Operculum oblong, rounded at each end. Animal olive.

1. S. Norvegica, Forbes \& Hanley, B. M. t. 107 ; t. 108. f. 7-9.

\section{B. Siphon recurved. Canal of shell very short and recurved, or reduced to a notch.}

c. Pisaniana. Shell with rudimentary varices. Operculum ovate, acute; nucleus apical; 'edge entire.

\section{Pisania.}

Shell ovate; spire conic, generally waved by the rudimentary varices; mouth ovate; inner lip with a few slight plaits in front. Operculum ovate, acute.

1. P. striata, t. 90.f. 3, t. 98. f. 1, t. 98. f. 8.

2. P. civetta, t. 87 a. f. 3 .

3. P.? lineata, t. 5. f. 5.

4. P. ignea, t. 5. f. 2.

5. P. cincta, t. 5. f. 7 .

6. P. violacea, t. 5. f. 8.

7. P. fasciolata, t. 5. f. 4 .

8. P. —, n.s., t. 102 . f. 20.

9. P. undosa, t. 30 . f. $1-4$.

10. P. vittata, t. 34. f. $18,19$.

11. P. lineolata, t. 5. f. 1 .

The teeth of Pisania striata are $1 \cdot 1 \cdot 1$, central, crescent-shaped, with five subequal, flat, tapering dentations; lateral with a single, acute, bent-up lobe, and slightly produced at the angle.

The lingual membrane of Pisania —— ? is narrow elongate, dark brown; inner end dilated ovate, darker, nearly opake. Teeth $1 \cdot 1 \cdot 1$, central rather broad ovate, three-toothed in front, lateral conical, slightly curved. 


\section{Columbella.}

Shell obovate or fusiform; mouth linear, ovate; canal short, curved. Operculum ovate, acute.

1. C. rustica, t. 11.f. 6,7, t. 98. f. $2,4,5$.

2. C. semipunctata (Pyrene s.), Adams, Gen. Moll. t. 19. f. 8.

3. C. mendicaria, t. 98 . f. 7 .

4. C. Pavtensis, t. 98. f. 6.

5. C. pardalina, t. 98 . f. 3 .

6. C.? lanceolata, t. 81 a. f. 2.

7. C. ? Barnet, t. 24. f. 10.

8. C. fulgurans, Adams, Gen. Moll. t. 19. f. 7, $7 b, 7 c$.

The operculum of Columbella zonata is triangular, ovate; nucleus apical, acute, the basal end subtruncate; outer edge subdentate; scar basal, oblong, submarginal, brown, white-edged. The lingual membrane is linear elongate; teeth $1 \cdot 1 \cdot 1$, central with five denticles, the three middle larger, central rather the largest, lateral denticles very small; lateral teeth with a kneed apex with a conical basal tooth.

In Columbella punctata the proboscis is elongate, black at the tip. Teeth $1 \cdot 1 \cdot 1$; the central transverse, simple; lateral hooked, hamate, with a large basal lobe nicked at the middle, and a subterminal tooth like the recurved tip. Operculum ovate, acute; edge entire, larger end rounded; nucleus apical, subacute, upper part slightly curved; scar oblong, oblique at the broader edge, leaving the upper part free; brown, upper part whitish.

In Columbella semipunctata the teeth $1 \cdot 1 \cdot 1$; central transverse, oblong, quite simple; lateral hamate, versatile, with two curved apical teeth. Operculum ovate, lanceolate, brown; nucleus apical, subacute; lower edge rounded; scar roundish, submarginal, with an - interruption in the middle of the upper edge.

Teeth of Columbella mendicaria $1 \cdot 1 \cdot 1$; the central narrow, with three large teeth in the middle, and with three small teeth between them. The lateral teeth short, with long conical basal and larger terminal lobe.-Morch.

Teeth of Columbella mercatoria $1 \cdot 1 \cdot 1$; central transverse, edentate, lateral elongate, oblong, nearly equally broad, with two or three hooked teeth near the top. C. rustica, C. strombiformis and $C$. unicolor have very similar teeth.

Teeth of $C$. gibberula $1 \cdot 1 \cdot 1$; the central transverse, edentate, the lateral narrow, slender, with two or three subterminal teeth. C. rugosa has similar teeth, but the lateral ones are narrower and the dentations more spread over the edge.--Morch.

\section{Engina.}

Shell ovate; mouth ovate, linear; pillar concave, with a broad oblique plait in front; inner lip expanded, veined; outer lip thickened internally and toothed with a groove behind (externally). Teeth — ? Operculum ovate, acute, curved. 
Shell most like Pisania, but resembles some Ricinule and $P$ urpurce in form; it differs from them in the inner lip being extended. and veined. When young, the lips are simple; throat smooth; pillarlip concave, with a distinct oblique plait in front margining the canal.

1. E. zonata.

2. E. pyrostoma, Adams, Gen. Moll. t. 19. f. 11, shell only.

\section{Triumphis.}

Shell ovate, covered with a thick coarse velvety periostraca hiding the colour; spire conic; whorls convex; outer whorls larger, and irregularly covering the rest. Mouth ovate; inner lip smooth; canal very short, recurved. Teeth three; central three-toothed; lateral large, hamate, three-toothed, onter largest. Operculum ovate, thick ; nucleus apical.

I. T. distorta.

It lives in crevices of rock between the low-water mark of the neap tides and that of the spring tides on the reef of Panama (Adams).

d. Cominellina. Shell smooth, without rudimentary varices. Operculum ovate, acute.

\section{Latrunculus.}

Shell ovate; spire conical; whorls smooth, flattened behind; axis umbilicated; lips smooth. Foot moderate, rounded behind. Operculum ovate, acute, edge entire.

1. L. areolatus, t. 93. f. 2 .

2. L. spiratus, t. 85 a. f. 4 ; Adams, Gen. Moll. t. II. f. 5.

\section{Cominelia.}

Shell like Buccinum; inner lip sometimes slightly concave; axis closed; last whorl sometimes rather irregular, callous behind, and partly covering the others. Operculum ovate, acute, outer edge smooth.

1. C. testudinea, t. 14. f. 1,3 .

2. C. maculosa, Reeve, Icon. f. 85 .

3. C. pluriannulata.

4. C. ligata.

5. C. lagenaria.

6. C. limbosa.

7. C. lineolata.

8. C. acutinodosa.

9. C. costata, t. 102 . f. 9 .

10. C. virgata, Quoy, Voy. Astrol. t. 30. f. 18; Adams, Gen. Moll. t. 11 . f. 6 .

The teeth of the male and female Cominella maculos are alike; 
central tooth tridentate; lateral with one basal elongated lobe, and one terminal. The teeth of the females are perhaps rather the largest.

Lingual membrane of Cominella — ? from the Cape of Good Hope, linear elongate, transparent. Teeth $1 \cdot I \cdot 1$, transparent, the older one yellow; central transverse, band-like, as broad as the space between the lateral teeth; front edge straight, with five small, nearly equal toothlets in the middle; the hinder edge rather concave towards the front; lateral teeth broad, front edge of the lower part with three very unequal, acute lobes near the base, the middle lobe largest; the outer hinder angle rather produced; the terminal lobe large, acute, curved.

Lingual membrane of Cominella — ? is elongate, linear, transparent; older teeth yellowish. Teeth $\mathrm{l} \cdot \mathrm{I} \cdot 1$; central band-like, transverse, not so broad as the space between lateral teeth; front edge nearly straight, with three nearly equal, large, conical teeth in the middle; hinder edge bent in the greater part of its length, rounded at the hinder end; lateral teeth with a large curved process on the inner edge of the base and a much larger one at the end; the outer hinder angle rather produced.

\section{e. Nassina. Operculum ovate, serrated on the outer edge; foot nicked behind.}

\section{Bullia.}

Shell ovate or turrited; whorls smooth; mouth ovate; lips simple; hinder part of inner lip thickened, making a callous band on the suture. Eyes none. Foot very large, expanded, square, with two small lobes behind. Operculum small, ovate; outer edge toothed.

1. B. lævigata, t. 20. f. 2, 3 ; Adams, Gen. Moll. t. 12. f. 3.

2. B. achatina, t. 20. f. 1 .

3. B. Cochlidium, t. 98 . f. 9.

4. B. globosa, t. 98 . f. 10 .

\section{NASSA.}

Shell ovate; spire short; whorls convex, waved, rarely variced; mouth moderate. Eyes distinct. Foot moderate, truncated and tentaculated in front, nicked behind. Operculum moderate, serrated.

1. N. coronata, t. 21 . f. 2.

2. N. arcularia, t. 98 . f. 14, t. 21 . f. 1, t. 102 . f. 11, t. 21 . f. $9,10$.

3. N. olivacea, t. 21 . f. 6, t. 85 a.f. 2 , var. f. 6 .

4. N. gemmulata, t. 85 a.f. 7.

5. N. crenulata, t. 85 a. f. 3 .

6. N. xanthostoma, t. 85 a. f. 5 .

7. N. Isabella, t. 98. f. 12.

8. N. dentifera, t. 98. f. 11 .

9. N. riparium, t. 97 . f. 1 .

10. N. Thersites, t. 21. f. 3 . 
11. N. pauperata, t. 21. f. 4 .

12. N. fasciata, t. 21 . f. 5 .

13. N. globosa, t. 21 . f. 7 .

14. N. reticulata?, t. 21 . f. 8 .

15. N. gibba, t. 102 .f. 11 , t. 21 . f. $9,10,11$.

16. N. cornicula, t. 24 . f. 11 .

17. N. ascanias, t. 21 . f. 12 .

18. N. —?, t. 85 a. f. $1,2,3,5,6,7$.

19. N. (Cyclope) neritea, t. 24. f. 8; Adams, Gen. Moll. t. 12. f. 8.

20. N. $\longrightarrow$ ?, t. 102 . f. 13 .

21. N. lævis, Adams, Gen. Moll. t. 12. f. 7.

22. N. incrassata, Forbes \& Hanley, B. M. t. L.L. f. l.

23. N. varicosa, Forbes \& Hanley, B. M. t. L.L. f. 2.

24. N. reticulata, Forbes \& Hanley, B. M. t. L.L. f. 3.

The central teeth of Nassa are broad, arched, pectinated; the lateral teeth with a basal hook.

The Nassa annulata has the front of the central tooth entirely pectinated; the scape of the lateral tooth largely spinulose.-Lovén, t. 5. f. 7 .

The central tooth of $N$. reticulata angularly produced into an angle in front, each edge smooth at the angle; the scape of the lateral tooth unarmed.-Lovén, t. 5. f. 8.

The central tooth of $N$. incrassata produced into an incurved angle in front, edge on each side smooth; the lateral tooth broad, with a larger, one-spined, basal tooth.-Lovén, t. 5. f. 9.

The central tooth of $N$. arcularia narrow, united in front; sides smooth; the scape of the lateral tooth smooth, with a longitudinal lamina between the base of the teeth.-Loven, t. 5. f. 10.

The tongue of Nassa (reticulata?) is linear, very transparent. Teeth $1 \cdot 1 \cdot 1$, central crescent-shaped, with twelve subulate, subequal, elongate toothlets; lateral teeth angular, bent, outer angle rather produced, base simple, narrow, apex acute, rather curved.

The egg-cases are small, ovate, acute, in series on sea-weeds, corallines, \&c.-Peach, Ann. \& Mag. Nat. Hist. xiii. 1844, 204. fig.

\section{Desmoulea.}

Shell subglobose; spire short. Teeth _-? Operculum subtrigonal, truncated, dentated.

1. D. pinguis, Adains, Gen. Moll. t. 2. f. 6.

f. Phosina. Operculum with a notch on the left side of the tip. Shell with a slight sinus in the front of the outer lip, like the Strombs.

\section{Phos.}

Shell ovate or turrited; spire conic; whorls undulated; mouth ovate; outer lip with a sinus in front; inner lip with a sharp fold in front. Tentacles linear; eyes within one-third of the tip, very thin above the eves. Foot folded across, dilated in front, with a small 
acute lobe on each side, and a single elongated flament behind. Teeth $1 \cdot 1 \cdot 1$. Operculum ovate, triangular, acute, with two longitudinal folds; apex acute, membranaceous, with a notch on the outer or left side; nucleus subapical, on a level with the notch.-Adams, Gen. Moll. t. 12. f. 5.

1. P. senticosum, Quoy, Voy. Ast. t. f. .

2. P. textum, Adams, Gen. Moll. t. 12. f. 5.

The operculum of Phos senticosum is on the back of the expanded foot, as in the animal of most of the Nassce, which it altogether resembles, except that the hinder extremity (of the foot) is serrated, and has one tail instead of two as in Nassa. I never saw it use its operculum when walking,-Trail, MSS. 1853.

\section{Cyllene.}

Shell ovate or obconic; spire conic, short, with a deep sharp-edged groove on the suture; mouth ovate. Operculum ovate, lanceolate, with an oblique central groove; apex acute; nucleus apical; outer edge smooth. Animal L_? 'Teeth — ?

1. C. Owenii, Gray, in Beechey Doy. 108.

\section{Northia.}

Shell turrited; spire acute; mouth ovate; inner lip thin, smooth, with a sharp keel over the canal ; outer lip crenated, toothed. Operculum ovate, elongate; apex slightly curved, with a notch on the outer side.-Adams, Gen. Moll. t. 12. f. 1 a, b. Teeth - ?

1. N. pristis, t. $84 a$. f. 4 .

Northia is found at low-water mark at Panama; the outer lip of old shells is much thickened.-C. B. Adans, 295.

The account of the operculum is on the authority of the specimen figured by Mr. Adams; the specimen in the British Museum has an oblong operculum, with an elongated nucleus on the front of the outer side, like Buccinum; but perhaps it is surreptitious.

\section{Fam. III. BUCCINIDÆ.}

Head truncated. Tentacles moderate. Mantle enclosed. Operculum horny, annular, oblong; nucleus on the outer edge.

Shell external; pillar smooth or concave.

A. Operculum oblong; nucleus elongate, occupying the long outer edge (fig. 10).

a. Rapanina. Siphon produced; canal of shell rather elongate, bent up at the end.

\section{Rapana.}

Shell subglobose or top-shaped; spire short; whorls lamellar, 
rapidly enlarging ; mouth ovate; inner lip smooth ;

Fig. 10.

canal open, bent up. Proboscis rather short, thick. Operculum of Rapana. Teeth $1 \cdot 1 \cdot 1$; central broad, three-lobed; lateral kneed, simple, apex incurved. Operculum ovate; nucleus on the middle of the outer edge (fig. 10).

1. R. Bezoar.

2. R. Rapa. (Operculum, Voy. Venus, t. 7.f. 2.)

3. R. xanthostoma.

4. R. cassiformis, t. 87 a. f. 8 .

5. R. crassilabrum, t. 87 a. f. 2 , t. 89 . f. 4 .

6. R. ricinuloides, t. 7 . f. 5 .

7. R. kiosquiformis, t. 87 a. f. 6 .

8. R. imperialis.

9. R. saccellum.

Rhizochilus.-A Rapana that lives on Antipathes, and at certain periods of its life closes its shell with a calcareous secretion, and permanently fixes itself to the coral, where it eventually dies. See Gray, Ann.\& Mag. Nat. Hist. Dec. 1851, 477; Adams, Gen. Shells, t. 14.f. 5 .

\section{Vitularia.}

Shell fusiform; whorls with several angular varices; mouth triangular, elongate; canal moderate; outer lip toothed within. Operculum horny, oblong; nucleus on the middle of the outer edge.

1. V. miliaris.

2. V. salebrosa.

3. V. abbreviata.

4. V. fiscellum.

In Vitularia fiscellum the lingual membrane is broad. Teeth $1 \cdot 1 \cdot 1$, brown; the central with a long, transverse, central tooth, and a smaller one on each side; lateral hamate, curved, simple, acute. Operculum oblong, rounded at each end; nucleus linear, on the front edge of the outer margin.

\section{Chorus.}

Shell top-shaped; spire short; whorls smooth, rapidly enlarging; mouth ovate; outer lip with a strong tooth in front; inner lip smooth; canal wide behind, tapering, open. Operculum horny, ovate; nucleus elongate, external.

1. C. giganteus.

\section{Cuma.}

Shell fusiform, solid, spirally striated; spire conical; mouth ovate; outer lip crenated; inner lip with a strong, rather oblique ridge. Operculum ovate, blunt; nucleus elongate, external, unequal.

1. C. sulcata, Swains. 
b. Purpurina. Siphon recurved; canal of shell reduced to a notch.

$$
\text { * Shell free. }
$$

\section{Nitidella.}

Shell fusiform, solid; spire conical, elongate ; apex sometimes deciduous ; mouth ovate; inner lip smooth ; outer rather contracted in the middle. Operculum like Purpura. Teeth - ?

1. N. concinua.

2. N. Gervilliæ.

3. N. cribraria, t. 24. f. 6.

4. N. avara.

5. N. sertularia, t. 99 . f. 5 .

6. N. labrosa, t. 81 a.f. 4 .

\section{Purpura.}

Shell ovate; mouth ovate; outer lip simple, lined or toothed within; inner lip concave, simple.

1. P. hæmastoma, t. 97.f. 7 ; t. 106. f. 1.

2. P. patula, t. 95. f. 2 .

3. P. rugosa, t. 96 . f. 7 .

4. P. Thiarella, t. 96 . f. 8 .

5. P. hippocastanum, t. 96 . f. 9 .

6. P. mancinella, t. 96 . f. 12 .

7. P. chocolata, t. 97 . f. 6 .

8. P. sertum, t. 97 . f. 3 .

9. P. armigera, t. 14 . f. 4 .

10. P. textilosa, t. 14. f. 6 .

11. P. coronata, t. 14. f. 5 .

12. P. haustrum, t. 13. f. 2,6 .

13. P. undata, t. 87 a. f. 1.

14. P. Harpa, t. 87 a. f. 10.

15. P. sertularia, t. 99. f. 5 .

16. P. - Pourpre de Chusan, t. 87 a.f. 6.

17. P. echinulata, t. 266 . f. 4.

18. P. Quoyii, t. 13. f. 7.

19. P. Helena, t. 96 . f. 1 .

20. P. tuberculata, t. 87 a. f. 4 .

21. P. neritoidea, t. 96 . f. 10 ; t. 266 . f. 3.

22. P. hystrix, t. 96. f. 4 ; t. 87 a. f. 7 .

23. P. - t. 96. f. 5. Animal cut open.

24. P. Lapillus, Forbes \& Hanley, B. M. t. 44. f. 4.

Central tooth of Purpura Lapillus transverse, three-toothed in front; teeth subequal, the side ones spinulose, winged; the lateral teeth far apart, small, scape broad at the bend, tip hooked.-Lovén, t. 5. f. 17 .

\section{Concholepas.}

Shell ovate, ear-shaped; aperture very large; outer lip with two or three small teeth in front. Operculum small.

l. C. peruviana, t. 13. f. 1,3 ; t. 95 . f. 1 . 


\section{Acanthiza.}

Shell like Purpura; inner lip concave, simple; outer lip with a strong tooth in front. Operculum like Purpura.-Adams, Gen. Moll. t. 13. f. 7.

1. A. striata, t. 87 a.f. 9.

2. A. unicornis, t. 97. f. 2.

\section{Sistrum.}

Shell ovate; mouth narrow, anterior; inner and outer lips with large teeth contracting the mouth. Operculum oblong.-Adams, Gen. Moll. t. 13. f. 6 .

l. S. ricinus, t. 96 . f. 2.

2. S. dactyloides, t. 96 . f. 3.

3. S. nodum, t. 96 . f. 6 .

4. S. horridum, t. 13. f. 4 ; t. 96 . f. 11 ; t. 97 . f. 5 .

\section{** Shell living fixed in holes in coral.}

\section{Magilus.}

Shell of young animal ovate, subglobose, thin; the carity simple, gradually filled up, and the whorl produced into a straight line, with a small cavity at the end for the body, so as to keep the animal on a level with the surface of the coral, the solidified shell being left fixed in the substance of the coral.

The young shell has been called a genus, Leptoconchus, and is said to have no operculum.-Adams, Gen. Moll. t. 14. f. 9.

I. M. antiquus, t. 24. f. 5 .

These shells have been taken for Stalactites or mineral concretions, especially when the cavity of the body has been broken off. They live in or on coral. The extension of the shell is to allow the animal to keep its body on a level with the surface of the growing coral, that it may be able to procure its food. It was placed by Lamarck with the Annelides or Worm-shells, and considered by Guettard as a mineral.

B. Operculum ovate; nucleus small, near the front end of the outer edge, or subcentral within the outer margin. Buccinina.

\section{Buccinum.}

Shell ovate; spire moderate; mouth oblong; outer lip rather sinuous; pillar rounded. Operculum ovate-_Adams, Gen. Moll. t. 11 . f. 4 .

* Operculum oblong; nucleus marginal.

1. B. undatum, t.9. f. 4, t. 92. f. 4 ; t. 94. f. 1; Forbes \& Hanley, B. $M$. t. 44 . f. 5 . 
** Operculum subcircular; nucleus subcentral, within the margin.

2. B. Humphreysianum.

3. B. glaciale.

The central tooth of Buccinum undatum pectinated, with 7 denticles; the scape of the lateral tooth three-toothed, the basal denticles the largest (see fig. 1. p. 3).-Lovén, t. 5. f. 4.

The central tooth of Buccinum cyaneum with 5 denticles; the lateral teeth acutely angulated, the scape two-toothed, the basal tooth much the broadest.-Lovén, t. 5. f. 5 .

Dr. Juovén figures Buccinum undatum as having seven toothlets on the central, and three on the base of each of the lateral teeth (t. 5 . f. 4) ; Chrysodomus antiquus (t. 5.f. 1) as having three denticulations on the central, and three lobes on the basal part of the right, and two on the basal part of the left lateral tooth. The teeth of these two genera have been exhibited and sold in London as the teeth of the two sexes of Buccinum undatum, the animals of which are both sold under the name of Whells.

\section{Gastridia.}

Shell top-shaped, solid; spire short; mouth ovate; outer lip with a strong tooth in front; inner lip very thick, callous; canal short. Operculum oblong, rounded at each end; nucleus small, in the centre of the outer edge; scar very large, shaped like and nearly as large as the operculum, with a thicker margin on inner sides and ends. Animal and teeth unknown.

1. G. plumbea, Adams, Gen. Moll. t. 13. f. 8, shell and operculum.

Fam. IV. PUSIONELLAD

Head small. Mantle enclosed. Teeth —? Operculum horny, half-ovate; nucleus on the middle of the straight inner side (see fig. 11).

Shell fusiform or turrited; canal rather produced, bent up at the end; pillar simple, smooth.

Fig. 11.

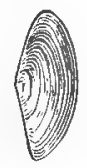

\section{Pusionella.}

Shell fusiform or turrited, smooth, covered with a thin, hard, polished periostraca ; whorls smooth ; mouth ovate; outer lip simple, acute, inner smooth; pillar with a short, acute fold at the base of the short open siphon. Animal __? Teeth - ? ? Operculum horny, half-ovate; nucleus on the middle of the straight inner side.

1. P. Nifat.

2. P. buccinata, Adams, t. 24. f. 3, operculum.

3. P. aculeiformis. 
Fam. V. TURRITIDA.

Head truncated. Tentacula moderate. Mantle enclosed. Siphon produced, recurved. Foot simple. Operculum none.

Shell fusiform; spire conical; pillar with large oblique folds in front; canal distant, rather produced, bent up at the tip.

\section{Turris.}

Shell fusiform; spire conical; whorls compressed; aperture linear; pillar lip obliquely folded; outer lip striated within.

1. T. corrugata, Quoy, t. 28. f. 2 ; t. 106. f. 7.

2. T. caffra, t. 81 a. f. 3 .

3. T. stigmataria, t. 28 . f. 8 ; t. 106. f. 3 .

4. T. paupercula, t. 128 . f. 7 .

The penis of Turris caffra is elongate, bent up. The siphon moderate, simple at the base. Proboseis not produced. Lingual membrane elongate. Teeth $1 \cdot 1 \cdot 1$; central transverse, rather angularly produced in the centre, with nine teeth on the front edge, the lateral largest; lateral teeth elongate, subulate, curved (semicircularly).

\section{Fam. VI. CANCELLARIAD $\approx$.}

Tentacles conical, subulate, close together at the base. Eyes external, basal. Proboscis —? Teeth —? Foot produced in front. Mantle enclosed. Siphon none? " not produced." (D'Orb.)

Shell ovate; spire short; whorls convex, striated or costated; mouth ovate, angular in front, with an indistinct siphonal notch; pillar lip with oblique plaits. Operculum —?

\section{Cancellaria.}

Character of family.

1. C. tuberculata, t. 89. f. 5 .

2. C. trigonostoma, t. 91 . f. 5 (not good; perhaps altered from former).

3. C. textilis, Adams, Gen.Moll. t. 29 . f. 4.

\section{2. ? Admete.}

Foot large, longer than the shell, broad, truncated, sinuated in front, lanceolate behind. Head small, rounded; mouth simple, without any proboscis or lingual membrane. Tentacles elongate, filiform. Eyes on minute tubercles on the outer side of the base. Operculum none.

Shell ovate, diaphanous, brittle; aperture ovate, scarcely nicked in front; pillar arched, obliquely truncated; lip thin, acute.

1. Admete crispa, t. 125 . f. 1 . 
** Foot very large, with a cross-groove on each side, often covering the shell, and producing a polished coat on it (see p. 10).

Fam. VII. OLIVIDA.

Siphon of mantle recurved. Head small. Foot often enclosing a part of the shell, with a cross groove on each side in front. Mantle enclosed. Canal of shell reduced to a notch. Operculum horny, small, annular, or none.

a. Olivina. Shell subcylindrical, smooth, polished; suture with a deep channel; pillar plaited in front. Mantle with elongated posterior process enclosed in the groove of the spire. Lateral teeth broad, ovate. Operculum with subapical nucleus, or wanting.

\section{Strephona.}

Shell subcylindrical; mouth linear. Frontal lobes small, acute. Operculum none.

1. S. sanguinolenta, t. 18. f. 1 .

2. S. textilina, t. 18. f. 2.

3. S. elegans, t. 18. f. 3.

4. S. erythrostoma, t. 18. f. 4.

5. S. Maura, t. 18. f. 5 ; t. 102. f. 5.

6. S. senegalensis, t. 83 a. f. 1 .

7. S. Ispidula, t. 101. f. 2,3 .

8. S. —, t. 100 . f. 3 .

9. S. mauritiana, Adams, Gen. Moll. t. 15. f. 4.

Foot of Strephona textilosa folded longitudinally. Lingual membrane slender, transparent. Teeth $1 \cdot 1 \cdot 1$ ?; central transverse, very short, three-toothed; the lateral toothlet twice as large as central; lateral teeth triangular, rather curved at the tip, the outer rather the largest. Operculum none.

Tongue of Strephona Ispidula linear. Teeth I・1・1; central broad, three-toothed in front; lateral small, lanceolate, ovate, acute, slightly curved, variable. Operculum none.

Teeth of Strephona cruenta $1 \cdot 1 \cdot 1$; central three-toothed in front, central denticle smallest; lateral ovate; when seen one over the other, they appear narrower and subhamate.

M. d'Orbigny described the aquiferous pores on the underside of the foot, common to most marine Gasteropods, as a particular character of the Olivida, observing that it is nearly unique among the Gasteropods!- Cuba, 104 .

\section{Olivella.}

Shell subcylindrical; mouth linear. Frontal lobes of animal small, acute. Operculum distinct, half-ovate, rounded at each end, thin; nucleus subapical, rather curved and within the edge.

1. O. volutella, Eydoux, t. 83 a. f. 2 . 
2. O. columellaris, Eydoux, t. 83 a. f. 3 .

3. O. Puelchana, t. 101. f. 1 ; t. 102. f. 1 .

4. O. Tehuelchana, t. 101.f.4; t. 102.f. 2 ; Adams, Gen. Moll.t. 15. f. 5 .

Olivella semistriata is found moving about by hundreds, with great rapidity, in the wet sand in Panama (Cuming). Like other species of the genus, the shells are often inhabited by Pagur

Olivella volutella is found in vast numbers over many acres on the sandy beach west of the city of Panama; most numerous where the beach has a gentle slope midway between high and low water mark. Some time after the retreat of the tide, it is found crawling about with much vivacity on the wet sand. The shell, while the animal is moving, is wholly covered with the mantle, and the mantle is entirely concealed with a thick coat of sand. When the first wave of the returning tide strikes them, washing off their coat of sand, they instantly bury themselves.-Adams, Ann. Lyc. New Fork, 1852, 281.

Has not the vesicular foot here been mistaken for the mantle?

\section{Scaphula.}

Shell orate; mouth expanded ; belt narrow. Frontal lobes of animal very large, rounded. Operculum distinct, half-ovate, nucleus subapical.

1. S. auricularia, t. 100. f. 1 ; t. 102. f. 6 ; Adams, Gen. Moll. t. 15. f. 2 .

\section{Agaronia.}

Shell ovate, acute; mouth large, expanded; front of pillar twisted and cross-grooved ; belt double, wide. Frontal lobes of animal moderate, acute. Operculum distinct.

1. A. hiatula, t. 101 . f. $4,6,7$.

2. A. megalostoma, Adams, Gen. Moll. t. 15. f. 3.

b. Ancillarina. Shell subcylindrical, polished; suture callous. Mantle without any posterior beard; lateral teeth simple, curved (fig. 12).

* Shell more or less covered with an enamel coat; outer lip often with a tooth in front.

\section{Ancilla.}

Spire covered with an enamel coat, forming a narrow belt on the penultimate whorl, not reaching to the hinder part of the mouth, and leaving a naked space on the whorls; axis imperforate; outer lip with a slight tooth. Operculum large, distinct, oblong, acute; nucleus subapical, near the front of the inner side.

I. A. australis, t. 19. f. 5 . 
2. A. ampla?, t. 19. f. 4 .

3. A. obtusa, Adams, t. 86 a. f. 1 ; Gen. Moll. t. 15. f. 7.

4. A. cingulata.

5. A. marginata?

6. A. lineata.

\section{SANDELla.}

Shell ovate, covered with an enamel coat, forming a broad belt on the whorls, and reaching in the penultimate whorl to the back of the mouth; axis imperforate; outer lip with an obscure tooth in front. Operculum —? Animal ——?

1. S. Tankervillii.

\section{EbURna.}

Shell entirely covered with an enamel coat; spire conical; axis deeply perforated; outer lip with an obscure tooth. Animal and operculum unknowa.

1. E. flavida.

\section{Sparella.}

Shell entirely covered with an enamel coat; spire conical, short; axis not perforated; outer lip often marked with an obscure tooth in front. Operculum - ?

1. S. albisulcata, t. 19. f. 1, 2, 3. Fig. 12.-Teeth of Sparella candida.

2. S. candida, t. 19 . f. 4.

3. S. ventricosa.

4. S. castanea.

5. S. aperta.

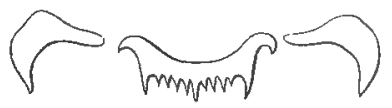

The central tooth of $\boldsymbol{S}$. candida three-toothed, with smaller intermediate denticles, the end produced, curved; the lateral tooth curved, hamate, armless at the base._Lovén, t. 5. f. 11, copied (fig. 12).

** Shell concentrically grooved, without any enamel coat; outer. lip thin, not toothed.

\section{Anolacia.}

Shell oblong, thin; spire short; outer lip thin, toothless; aperture large; axis imperforate. Operculum none. Foot very large. 1. A. mauritiana, t. 105.f. 1 .

c. Harpalina. Shell ventricose, variced; pillar smooth. Operculum none.

\section{HaRPa.}

Shell ovate-oblong, thin, polished, with numerous acute varices; spire short, acute; last whorl very large; mouth ovate, elongate, broadly notched in front; outer lip with a thickened external varix; pillar lip simple, smooth, rounded, pointed in front. Operculum none. Head large; proboscis elongate, conical. Teeth - ? Ten- 
tacles conical, close together over the mouth, with the eyes near their base. Foot very large, expanded, nicked on each side in front, elongate behind, often becoming truncated.

1. H. ventricosa, t. 22 . f. 1,2 ; t. 95 . f. 3 .

2. H. minor, t. 23. f. 1, 2; Adams, Gen. Moll. t. 15. f. 1.

The hinder part of the foot separates spontaneously when the animal is irritated.

b. Trapezodonta. Abnormal lateral teeth trapezoid, curved. Shell internal (see p. 10).

\section{Fam. VIII. LAMELLARIADA.}

Mantle covering the thin ear-shaped shell, produced, and with a deep notch in front in the place of the respiratory siphon. Head moderate. Proboscis elongate, strong, retractile. Mouth vertical, covered internally with a strongly armed horny epithelian or prehensile collar. Tongue linear, spirally twisted behind (as in Purpura Lapillus). Gills single, crescent-shaped, hence appearing double. Teeth $1 \cdot 1 \cdot 1$ or $2 \cdot 1 \cdot 2$; central simple, triangular, with diverging branches at the base; lateral trapezoid, simple, curved, toothed (fig. 13). Operculum none.

\section{Coriocella.}

Body oblong; mantle vesicular, areolated, with two narrow lobes in front. Foot small, narrow. Teeth $1 \cdot 1 \cdot 1$; lateral large, versatile. Shell large, spiral, internally ear-shaped.

1. Coriocella nigra, t. 104. f. 3 ; t. 104. f. 4 ; t. 167. f. .

The Coriocella nigra grows to a large size. The shell is green when fresh, but soon fades and becomes white. The foot is not onefourth of the size of the mantle. The trunk long, like that of Buccinum. The tentacles depressed, close together, united on the inner side over the top of the cavity of the proboscis, with the eyes near the tips. The canal of the mantle is very distinct and lined with a cartilaginous skin. Operculum none.

\section{Lamellaria.}

Body depressed, smooth, notched in front. Foot very large, broad, produced behind. Teeth $1 \cdot 1 \cdot 1$, lateral, large, rersatile (fig. 13).Lovén, t. 4.f. 15. Shell large, spiral, internally ear-shaped.

1. L. tentaculata, t. 103. f. 11 ; t. 103. f. 4 ; Forbes \& Hanley, Brit. Moll. t. P.P. f. 2.

2. L.? neritoidea, t. 103. f. 2.

3. L.? Audouini, t. 105. f. 3, 4.

Fig. 13.-Lamellaria.

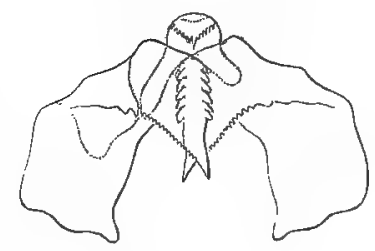

4. L. latens. Cryptocella 1., Adams, Gen. Moll. t. 21. f. 4. 


\section{Ermea.}

Body convex, smooth; mantle expanded, rather sinuous, simply notched in front. Foot small, corered by the mantle. Teeth $2 \cdot I \cdot 2$, like Lamellaria, "but with a small, slender, linear, arched, inner lateral tooth."'-Alder.

1. E. perspicua, t. 104. f. 2, t. 166. f. 3 ; Forbes \& Hanley, B.M. t. P.P. f. 1 ; Berg, Marseln. t. 1. f. 1-14. Lamellaria p., Philippi, Moll. Sicil. t. 10. f. 5?; Adams, Gen. Moll. t. 21. f. 3.

2. E. Adansoni, t. 103. f. 9.

3. E. convexa, t. 103 . f. 5 .

B. Odontoglossa, Gray. Teeth in three series, $1 \cdot 1 \cdot 1$; central and lateral fixed (fig. 14, 15). Operculum annular. Mantle siphoned. Shell channeled in front, with folds on the pillar (see p. 10).

\section{Fam. IX. FASCIOLARIAD王, Gray.}

Central tooth transverse; lateral teeth very broad, linear, with many equal denticles on the edge. Shell with plaits on the pillar.

a. Fasciolariana. Operculum ovate; nucleus apical; canal of shell elongate; central tooth narrow (fig. 14).

\section{Fasciolaria.}

Shell ovate, fusiform, swollen; spire conical; whorls smooth or waved; mouth ovate, open; outer lip crenated, lined within ; inner lip smooth; pillar with three or four very oblique plaits in front. Operculum ovate, acute, sometimes radiately grooved.

Fig. 14.-Teeth of Fasciolaria Tarentina.

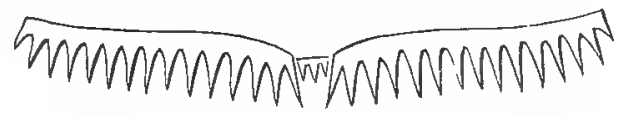

1. F. tulipa, Kiener, t. 86 . f. 2 ; Lamk. t. 87.

2. F. filamentosa, Quoy, t. 8. f. 5 .

3. F. Tarentina, Chiaje, t. 8. f. 4 ; Joannis, t. 89. f.

Tentacles of animal of $F$. tulipa close together at the base. Eyes near the middle of the tentacles. Teeth of $F$. flamentosa exactly like those of Latirus rusticus, $1 \cdot 1 \cdot 1$; central small, narrow, with three small denticles; lateral very broad, linear, not versatile.

Teeth of Fasciolaria Tarentina 1 * 1 * 1. Tongue linear, pale yellowish, nearly transparent, forming three nearly continuous bands; central narrow, about one-third the width of the lateral teeth, with four or five? small teeth on the nearly straight front edge; lateral wider, transverse, with six or eight? small teeth on the nearly straight front edge. 
Fasciolaria granosa is found among stones in muddy places near low water mark.

\section{LeUCozonia.}

Shell ovate, fusiform, swollen like Latime, but with a tooth at the end of an external groove in front of the outer lip. Operculum ovate, acute, rather curved.-Adams, Gen. Moll. t. 16. f. 6 a.

1. L. smaragdula, t. 35.f. 21 ; Adams, Gen. Moll.t. 16. f. 6 .

Central tooth of Leucozunia brasiliana narrow, three-toothed; lateral broad, many-toothed.-Morch.

\section{Latirues.}

Shell ovate, fusiform, swollen; spire moderate; whorls smooth or rather waved; mouth ovate; outer lip with a distinct tooth in front, grooved within; inner lip smooth; pillar with a few small transverse folds in front. Operculum ovate, acute.

1. L. rusticus, t. 8 . f. 6 .

2. L. lineatus, t. 8. f. 8 .

3. L. polygonus, t. 8. f. 7 .

4. L. nussatellus, t. 8. f. 1 ; Adams, Gen. Moll. t. 16. f. 5.

Lingual membrane of Latirus rusticus with three series of teeth; central narrow, recurved and three-toothed; lateral teeth very broad, linear, many-toothed on the edge, not versatile.

Central tooth of Latirus filamentosus narrow, three-toothed; lateral broad, many-toothed.-Morch.

\section{b. Mitrana. Operculum none. Canal of shell short. Central tooth broad, denticulated.}

\section{Mitra.}

Shell fusiform ; spire conical ; whorls compressed; mouth ovate, linear; outer lip smooth within; pillar with five plaits; mantle enclosed; siphon without any auricles at the base. Foot small, folded longitudinally when contracted. Operculum none.

1. M. episcopalis, t. 28. f. 6 ; t. 106. f. 4 . Central tooth broad.

2. M. adusta, t. 28. f. 3, 4. Central teeth narrow, simple, hooked.

3. M. maura, t. 106. f. 5 .

4. M. retusa, t. 28 . f. 5 .

5. M. nigra, t. 28 . f. 1 .

Proboscis of Mitra cucumerina thick. Teeth 1.1.1; central moderate, transverse, front edge arched with seven rather distant, conical, transparent teeth; lateral elongate, transverse, with numerous, rather distant, conical, transparent teeth on the front edge.

Tongue of Mitra adusta with teeth, $1 \cdot 1 \cdot 1$; central with a strong: hook and a small denticle on each side; lateral transverse, elongate, linear, with many teeth on the front edge, largest near the inner edge, and smaller near the outer. 
Trunk of Mitra episcopalis very long, cylindrical, exsertile, smooth, and ringed externally. Teeth $1 \cdot 1 \cdot 1$; central narrow, brown, transverse, with five strong teeth; lateral elongate, more than twice as long as the central one, transparent, with strong denticulations on the inner edge, gradually becoming smaller and more indistinct towards the outer end.

Proboscis of Mitra Ticaonica very long, large. Teeth $1 \cdot 1 \cdot 1$; central broad, with an arched front edge with eight subequal, conical, rather distant teeth, the outermost rather smaller; lateral teeth broad, transverse, with a series of many, rather distant, conical teeth on the front edge, the ontermost the smallest.

\section{Strigatella.}

Shell fusiform, smooth; pillar with five plaits; outer lip smooth within, with a large subcentral, internal thickening, leaving a posterior groove. Animal —— Teeth — ? Operculum _-?

1. S. zebra.

2. S. acuminata.

\section{Zierliana.}

Shell ovate, fusiform, thick; pillar with five plaits; outer lip thickened.

1. Z. Ziervogelii.

\section{Volvaria.}

Shell cylindrical; spire very short; whorls compressed; mouth linear. Animal and operculum unknown; being only found in the fossil state.

1. V. bulloides.

\section{IMBRICARIA.}

Shell obconic, smooth; spire conical; mouth linear; pillar with five plaits, the largest in the middle of the inner lip; outer lip simple, crenulated, smooth within. Animal. Foot folded longitudinally. Tentacles close; eyes on outer side above the base. Siphon elongate, simple. Proboscis elongate, slender. Teeth -? Penis very large, elongate. Operculum none.

1. I. marmorata, t. $45^{*}$. f. 3,4 .

2. I. conovula, t. 106 . f. 7 .

\section{Cylindra.}

Shell oblong, subcylindrical, spirally grooved; mouth linear; pillar with six or seven folds, the hinder larger, transverse, in the middle of the inner lip; outer lip crenated, smooth within. Animal. Proboscis very long, covered with conical tubercles about as long as broad. Teeth — ? Operculum —- ?

1. C. nucea, Adams, Gen. Moll. t. 19. f. 5.

2. C. crenulata. 


\section{Fam. X. TURBINELLID无.}

Teeth $1 \cdot 1 \cdot 1$; central few-lobed, broader than lateral; lateral teeth narrow, strong, with a single large lobe. Shell with an elongated straight canal, and large transverse fold on the pillar. Operculum ovate (fig. 16).

\section{Turbinellus.}

Shell ovate or top-shaped; spire conical; whorls smooth or rather waved; apex mamillated; mouth ovate, narrowed in front; outer lip simple; inner lip smooth; pillar with several large transverse plaits; canal wide, straight. Operculum ovate, inner edge straight. Animal

1. T. pyrum.

Fig. 15.

Teeth of Cyn. cornigera.

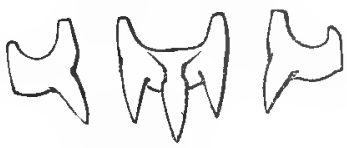

Fig. 16.

Operculum.

\section{Cynodonta.}

Shell ovate, fusiform; spire conical; mouth elongate, oblong; outer lip —_? ; inner lip — ? pillar with distinct transverse plaits. Operculum ovate, inner edge curved (fig. 16).

1. C. cornigera, t. 8. f. 3 ; Adans, Gen. Moll. t. 17. f. 1.

2. C. ceramica, t. 93 . f. 3 .

3. C. pugillaris.

Animal of $C$. cornigera olive-green. Foot irregularly crumpled in front when contracted; proboscis very long; cylindrical, rather thicker at the end; lingual membrane elongate, narrow. Teeth in three rows, $1^{\cdot} I^{\cdot} 1$, equal; central strongly three-toothed; lateral with a lunate base, not reversible, with a single subcentral process (fig. 15).

C. Rachiglossa, Gray. Teeth in a single central series. Operculum annular or none. Mantle siphoned. Shell channeled in front; pillar plaited.(see pp. 10, 28).

\section{Fam. XI. VOLUTID E, Flem.}

Siphon of mantle very short, recurved. Shell with a nick in front for the siphon, and the front of the pillar regularly and deeply plaited. The foot is generally large, and often deeply nicked on each side in front. Lingual membraue linear, with one series of teeth (fig. 17-19). 
a. Volutina. Siphon with auricles on sides of base. Tentacles far apart, united by a broad veil forming a hood over the head. Eyes far back, behind the small tentacles.

+ Teeth broad, lunate; apex three-lobed (fig. 17).

A. Yetina. Animal viviparous; nucleus of shell very large, irregular, callous (fig. 18). Foot very large. Operculum none.

\section{Yetus.}

Shell ventricose, covered with a horny periostraca, more or less covered with a polished shelly coat deposited by the expanded mantle; spire very short, irregular; mouth expanded. Animal large, ovoviviparous; the young very large when born. Foot very large, partly covering the shell. Operculum none.
Fig. 17.-Yetus olla.

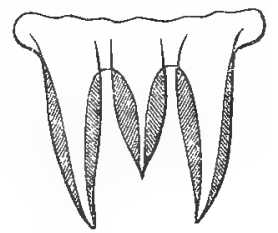

* Left side of mantle and inner lip rather expanded. Shell mottled; suture of adult broadly channeled.

1. Y. Navicula. Spire short.

2. Y. Cymbium. Spire subconic.

3. Y. gracilis. Spire produced.

** Left side of mantle and inner lip much expanded over the last whorl. Shell one-coloured.

4. Y. Neptuni, t. 25. f. 2 ; Kiener, t. 88. f. 3, t. 27. f. 4 ; Adams, Gen. Moll.t. 1.f. 3 . Var. Y. patula and Y. Tritonis. Suture channel wide.

5. Y. olla. Suture channel narrow, deep.

*** Left side of mantle and inner lip covering the whole outer surface of the shell.

6. Y. proboscidalis.

7. Y. porcina.

8. Y. rubiginosa.

The original surface, indicating the extension of the mantle over the surface of the shell in this and other genera of this family, is often destroyed in cabinet specimens, even in the most recentlyformed collections, which greatly deteriorates from their scientific value.

Fig. 18.

Young Y. proboscidalis.

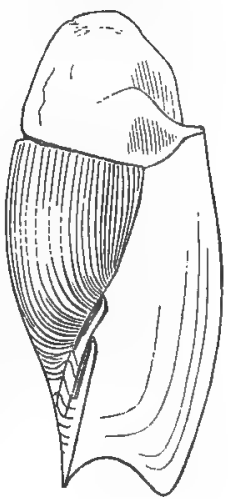


B. Animal oviparous; nucleus of shell regularly spiral. Foot moderate.

* Mantle enclosed; inner lip of shell defined, not expanded; pillar with five or six strong subequal plaits. Operculum none.

2. Cymbium.

Shell ventricose, covered with a horny periostraca; spire short, depressed, often imbricated; mouth very large, expanded.

1. C. melo.

\section{$\S$ Spire hidden.}

$\S \S$ Spire conic, hooded with spines; spines bent down towards tip.

2. C. nauticum.

3. C. æthiopicum, t. 25. f. 1 ; Adams, Gen. Moll.t. 17. f. 4. Shell brown.

4. C. Miltonis. Shell white and brown marbled.

§§ Spire conic; spines large, produced.

5. C. - ? Spines subequal, in adult state wanting.

6. C. armatum, t. 264 . f. 1, t. 265.f. 1. Spines becoming larger and much produced, and increasing with age.

$\$ \S \S$ Spire large; spines small, numerous, subinflexed.

7. C. Broderipï=C. Regius.

\section{Scapha.}

Shell ovate or fusiform; periostraca smooth, thin ; spire conic ; mouth moderate; inner lip even. Operculum none.

\section{Nucleus smooth.}

1. S. colocynthis, t. $27^{*}$. f. 2 ; Adams, Gen. Moll. t. 18. f. 1.

2. S. pacifica, t. 27. f. 3 , t. 263 . f. 1 .

3. S. fusus, t. 27. f. 2 ; Adams, Gen. Moll. t. 18. f. 3.

\section{$\$ \S$ Nucleus moderate, crenulated.}

1. S. vespertilio, t. 26. f. 1, 2, 3; Adams, Gen. Moll. t. 18. f. 2.

Mantle of Scapha vespertilio free for half an inch on pillar side; siphon elongate, produced, conical, with conical tentacular auricles on the sides of the base; penis elongate, conical, bent back, compressed; tentacles lateral, subulate, far apart at the base, and united by a broad veil fringed on the edge; lingual membrane elongate, narrow. Teeth in a single series, with three teeth in front, the central largest; hinder edge lunate. 


\section{Fulgoraria.}

Shell ovate, fusiform, striated; spire conical; nucleus small, regular; mouth elongate; pillar with a central thickening, covered with many irregular oblique plaits; canal rather produced, open. Animal —? Teeth —? Operculum — ?

1. F. chinensis. Voluta rupestris, Adams, Gen. Moll. t. 18. f. 6.

\section{Callipara.}

Shell oblong; spire short; nucleus small; mouth linear; pillar with two small plaits in front. Animal ——?

1. C. bullata, Adams, Gen. Moll. t. 17. f. 6, shell only.

** Mantle enclosed; inner lip of shell defined, not expanded; pillar lip with five or six strong subequal plaits. Operculum horny, distinet.

\section{Voluta.}

Shell ovate, striated, covered with a thin periostraca; spire conic; nucleus small, regular, spiral; mouth elongate; pillar with some large (four or five) oblique plaits in front, and more transverse ones behind.

1. V. musica.

*** Mantle enclosed; inner lip regular; front of pillar with two or three oblique plaits and some small ones behind. Opereulum ? Teeth -

\section{Lyrta.}

Shell fusiform; spire conic; whorls plicated; pillar lip with numerous small plaits behind the two larger front ones. Animal $\longrightarrow$ ? Operculum —?

1. L. festiva.

2. L. lyriformis.

3. L. mitræformis.

$\$ \$$ Outer lip moderate; inner lip with numerous cross grooves.

4. L. costata.

5. L. Delesseriana

\$§ Outer lip thickened behind, with a convex varix and strong internal central rib; inner lip smoothest. Enæta.

6. L. harpa. 
**** Mantle lobes produced and partly covering the shell; inner lip produced over body whorl.

\section{Volutella.}

Shell fusiform; spire acute, covered with a glassy deposit (often artificially removed in cabinet specimens); nucleus small; mouth ovate, elongate ; inner lip expanded, reflexed; mantle produced on left side. Teeth — ? Operculum none.

$\$$ Mantle lobes largely expanded, entirely covering the spire, which is often covered with a callous deposit.

1. V.angulata, t. 27*. f. 1. Zidona a., Adams, Gen. Moll. t. 17.f.5.

$\$$ Mantle lobes moderately expanded, covering the lower side of the spire and leaving a callous band on the suture of the upper side; spire often crowned.

2. V. Scapha, t. 81 a.f. 5 .

3. V. imperialis.

4. V. Cymbiola = Ausoba, Adams.

5. V. Sophia.

6. V. volvacea.

7. V. tuberculata.

\$\$ Mantle lobes moderately expanded, not covering the spire; suture simple; spire not crowned.

8. V. papillosa.

9. V. fusiformis.

10. V. fulgetrum.

11. V. ancilla.

†† Amoriana. Teeth linear, base angularly diverging, with a single conical apex; mantle enclosed; nucleus of shell small, regular, spiral. Animal oviparous? Operculum none (see p. 32).

\section{Amoria.}

Shell fusiform, polished; spire conical; suture with a callous edge; nucleus small, regular; mouth elongate; pillar with five oblique plaits.

1. A. Turneri.

2. A. undulata, t. 27. f. 1 .

Mantle lobes of Amoria Turneri not expanded; veil very large, with the elongated tentacle at its hinder margin; the eyes sunk at the base of their hinder edge; siphon with distinct ear-like lobes. Teeth in a single series, with two angularly diverging bases, and a central conical apex; the apices forming a continued vertical keel on the tonguemembrane (fig. 19).
Fig. 19.

Amoria Turneri.

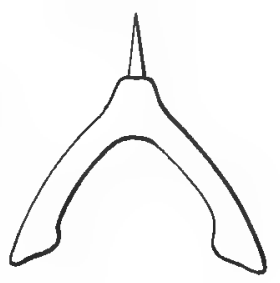

D 2 
b. Volutomitrina. Siphon simple at the base. Tentacles close together at the base. Mantle enclosed. Operculum none. Teeth with a narrow angular diverging base and a single conical apex.

\section{Volutomitra.}

1. V. Grœnlandica, Adams, Gen. Moll. t. 19. f. 2, shell only.

The foot of Volutomitra Gronlandica is obliquely folded across. Mantle enclosed. Siphon simple at the base. Tentacles close at the base, subulate, with eyes on large tubercles one-third above the base. Operculum none. Male; penis subcylindrical, folded back.

c. Porcellanina. Siphon simple at the base. Tentacles close together at the base. Mantle lobes expanded, covering the shell. Teeth in a single series, broad, transverse, band-like, with nine denticulations in front. Operculum none. Shell covered with a polished coat over the periostraca.

\section{Porcellana.}

Shell ovate; spire conic ; mouth oblong, longitudinal ; pillar with five distinct plaits in front. Mantle covering part of the shell,

1. P. glabella, t. 102. f. 11, 12 .

2. P. quinqueplicata, t. 83 a. f. 4 ; Petit, Journ. Conch. 38.

3. P.

4. P. ? marginella, t. 102. f. 8, shell naked?

5. P. secalina, t. 102. f. 4 ; Adams, Gen. Moll. t. 20. f. 5.

6. P. — ?, t. 102. f. 7.

7. P. diadochus (Marginella d.), Adams, Gen. Moll. t. 20. f. 2.

The mantle edge of Porcellana quinqueplicata is thin, enclosed when contracted from being in spirits; edge crumpled, free for half an inch on the pillar side. Foot moderate, folded longitudinally, double-edged in front. Siphon distinct, thick, without any auricle at the base. Tentacles subulate, thin, the right smaller, close at the base, united by a membranous band beneath, with the eyes on the outer side of the base. Proboscis quite retractile, short, thick. Lingual band elongate, transparent, convex, higher in the middle. Teeth in a single series, transverse, three times as broad as long; the front edge straight, with nine small teeth, the central rather the largest and further apart from each other, and the outer lateral smaller, with the angle sometimes wanting.

\section{Closia.}

Shell ovate, polished; spire very short; mouth linear; pillar with four plaits in front; plaits all close together, the two front largest and equal, two hinder smaller; outer lip crenulated.

1. C. Sarda. 
13. Persicula.

Shell oblong; spire short, hidden; mouth linear; pillar with numerous cross grooves; outer lip thickened externally. Mantle covering three-fourths of the shell.

\section{a. Inner lip simple.}

1. P. carneola?, t. 102. f. 3, copied Adams, Gen. Moll. t. 20. f. 3.

2. P. lineata, t. 4 . f. 4.

B. Inner lip callous, with a large cross fold in front; outer lip

3. P. interrupta. crenulated. Rabicea.

D. Tænioglossa, Gray. Teeth in seven series, $3 \cdot 1 \cdot 3$, the central and inner lateral fixed, the two outer lateral versatile.

A. Mantle siphoned, enclosed; mouth of shell channeled in front. Operculum annular or none.

Fam. XII. CASSIDID压.

Shell subglobose or triangular ; spire short; siphon of mantle and canal of shell recurved. Operculum ovate or oblong, annular; nucleus elongate in the middle of the inner side, rarely rudimentary or wanting. Teeth $3 \cdot 1 \cdot 3$, the central transverse, many-toothed in front, the inner lateral broad, many-toothed on the inner edge, the two outer lateral subulate, curved, the inner rather shorter, slightly toothed at the top, outer simple. Prehensile collar strong, thick, horny, armed with rows of numerous conic teeth.

In my former notice of the teeth of Cassis erinacens, I described the peculiar tooth-bearing collar for the lingual teeth.

a. Siphon elongate. Mouth of shell elongate, narrow.

\section{Cassis.}

Shell oblong or subtrigonal ; spire short, nearly flat ; whorls compressed, with a varix on each two-thirds of a whorl; mouth elongate, narrow; outer lip thickened, toothed within; inner lip callous, plaited. Operculum oblong, narrow, small; nucleus subcentral, submarginal.-Adams, Gen.Moll. t. 22. f. 1 b.

$$
\text { a. Shell subtrigonal. Cassis. }
$$

1. C. cornutum, Quoy. \& Gaim.Voy. Astrol. t. 45. f. 1.

$$
\text { } \beta \text {. Shell oblong; spire not variced. Cypræcassis. }
$$

1. C. rufum.

\section{Levenia.}

Shell oblong, ventricose; spire short, conical ; whorls compressed, 
without varices; mouth elongate, narrow, rather dilated in front; inner lip much expanded, cross-grooved; outer lip simple, sharp, strongly cross-grooved, erect behind, rather expanded in front; canal elongate, sharply reflexed. Animal ——? Operculum small.Adams, Gen. Moll. t. 23. f. 4 b, c.

1. L. coarctata.

b. Siphon elongate. Mouth of shell ovate.

\section{Bezoardica.}

Shell ovate, subglobose; spire short, often variced, whorls convex; mouth ovate; canal open, suddenly bent up; pillar veined or granulated; outer lip thickened. Operculum half-ovate, moderate, often radiately striated; nucleus on middle of straight inner edge.

1. B. glauca, t. 94 . f. 4, t. 16. f. 3.

2. B. Bezoar, t. 94 . f. 3 .

3. B. sulcosa, t. 94 . f. 4 , t. 16. f. 2 .

4. B. anceps (Semicassis a.), Adams, Gen. Moll. t. 23. f. 2.

Fig. 20.-Teeth of Bezoardica.

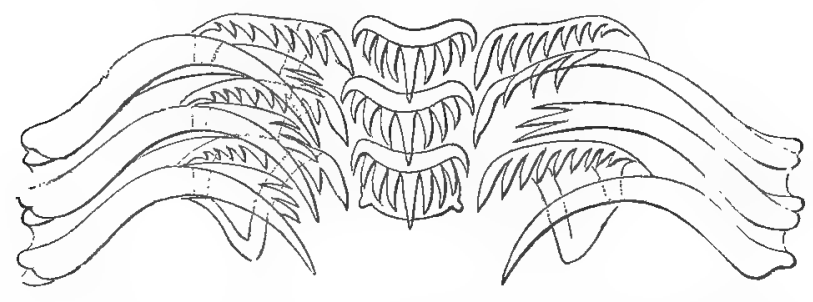

The lingual band of Bezoardica - ? narrow, elongate, transparent, brown at the end. Teeth $3 \cdot 1 \cdot 3$, the central rather narrow, transverse, upper edge marked with seven or nine elongated acute denticles, the central longest, the rest gradually shorter; the inner lateral tooth broad, transverse, strongly denticulated on the inner side of the upper edge; the two outer lateral elongate, subulate, versatile, curved for half their length; the inner pair rather shorter, with three or four denticulations on the inner side near the tip; the outer pair rather longer, and entire at the tip. The outer lateral teeth fold over together, and prove to be two series, as there are two opposite the end of each internal lateral tooth. The teeth are most like those of Trichotropis bicarinata, but the central and inner lateral teeth are denticulated (fig. 20).

The teeth of Bezoardica glauca $3 \cdot 1 \cdot 3$; central broad, with many equal denticulations; the inner? (outer ?) lateral broad, triangular, with many denticulations on the sloping edge; the outer (inner?) elongate, narrow, with three long acute denticulations at the tip.-Morch. 
Teeth of Bezoardica Saburon $3 \cdot 1 \cdot 3$; central with many toothlets, the middle largest ; inmer lateral denticulated; outer lateral subulate, curved, the middle one divided into three acute digitations at the end ; the collar thick, horny, symmetrical, with close cross rows of numerous conical acute teeth.

\section{Morio.}

Shell ovate, ventricose; spire short, not variced; mouth ovate; canal produced, slightly bent up; outer lip thickened, rather reflexed ; inner lip callous, cross-grooved in front. Operculum oblong ; nucleus on the front part of the inner side--Adams, Gen. Moll. t. 23. f. $6 a, b$.

1. M. Echinophora, t. 17. f. 3, Adams, Gen. Moll. t. 23. f. 6.

Proboscis of $M$. Echinophora cylindrical, conical, long, slender. Tentacles subulate, thick, placed on the sides of the base of the proboscis; eges on the outer side of their base. Male organ large. Siphon rather short. Foot small, oval, folded across. Operculum oblong, large, horny, solid, nearly straight on one side and rather narrow in front. "Teeth like Cassis."-Morch.

\section{Sconsia.}

Shell ovate, spirally striated; spire short, conical; mouth ovate, lanceolate; inner lip rather expanded, cross-grooved, with some irregular oblique plaits in front; outer lip thickened, slightly reflexed, internally cross-grooved and rather expanded in front; canal small, nearly straight, scarcely recurved. Operculum —? Animal —? 1. S. striata.

\section{Linatella.}

Shell ovate, costate; spire short; mouth ovate; outer lip slightly thickened; canal elongate, open, straight. Operculum small, oblong; nucleus subcentral, sublateral, near the middle of the outer? or hinder? margin. Teeth —?-Troschel, Wiegm. Arch. 1852, t. 6. f. 7 .

1. L. cingulata.

\section{Ranella.}

Shell ovate, compressed; varices two on each whorl, sharp-edged; mouth ovate; inner lip veined; canal open. Operculum half-ovate; nucleus central, lateral, internal (fig. 21).

1. R. crumena.

The shell is very similar to Apollon, but the operculum and form of the varix distinguish them.

Fig. 21.

Operculum of Ranella.

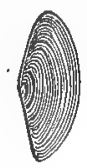


The tentacles of Ranella crumena are subulate, with the eyes at the outer side of their bases. The proboscis is very elongate, and the teeth $3 \cdot 1 \cdot 3$. The operculum ovate, subacute at each end, with the nucleus in the middle of the inner slightly curved edge.

c. Siphon short; canal reduced to a notch; mouth narrow. Animal and operculum unknown.

\section{Oniscia.}

Shell subconic, tapering in front; mouth linear; canal short, recurved; inner lip granular; outer lip reflexed, rounded, plaited across. Animal and operculum - ?

1. O. cancellata.

\section{Morum.}

Shell obconic, tapering in front; mouth linear ; canal short, truncated, scarcely recurved; inner lip inflexed, thickened, granular; outer one thin, toothed on the edge internally, with a thickened shelving outer edge. Animal and operculum —?

1. M. oniscus.

\section{Cithara.}

Shell ovate, elongate ; spire conic; whorls concentrically ridged; mouth linear, slightly channeled at each end; inner lip thin, rather expanded, cross-grooved; outer sharp-edged, with a thick shelving outer edge; throat grooved. Mantle enclosed. Tentacles subulate. Foot broad; siphon short, recurved. Operculum none.

1. C. Citharella.

2. C. marginelloides, Adams, Gen. Moll. t. 10. f. 9 .

\section{Pachyoathron.}

Shell oblong; spire very small; whorls cancellated; mouth linear, channeled at each end; inner lip rather dilated, cross-ridged; outer thickened, internally toothed.

1. P. cassidiformis, Adams, Gen. Moll. t. 20 . f. 4.

\section{Fam. XIII. DOLIID $F$.}

Head truncated. Proboscis very long, dilated at the end. Tentacles moderate. Eyes on outer side of base. Mantle enclosed. Siphon recurved. Lingual membrane broad. Teeth $3 \cdot 1 \cdot 3$; central tooth broad, three-lobed. Foot large, truncated in front. Operculum none.

\section{Dolium.}

Shell subglobose, ventricose, spirally grooved; spire short; last 
whorl very large; mouth large, ovate; canal suddenly recurved; outer lip more or less thickened, waved internally; pillar lip rather twisted, veined (figs. 22, 23).

Fig. 22,-Dolium perdix, with proboscis exserted and siphon recurved.

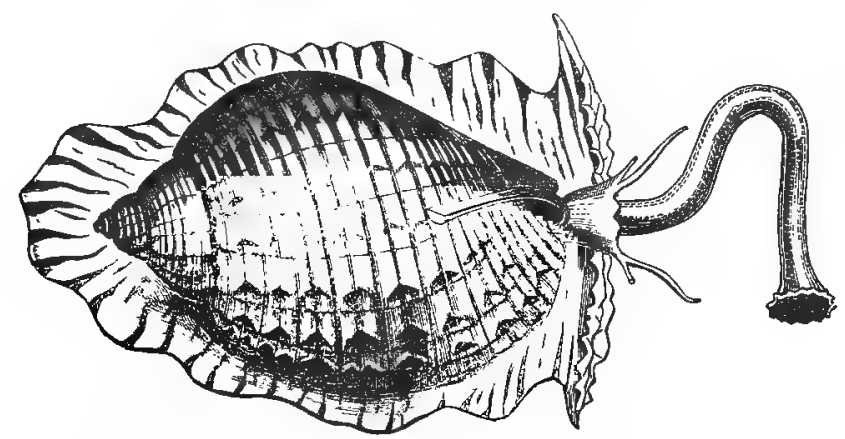

1. D. galea, t. 16. f. 1 , t. 93 . f. 1 .

2. D. olearium, t. 17. f. 1 ; Adams, Gen. Moll. t. 20. f. 6 .

3. D. perdix, t. 15. f. 1. Teeth (fig. 23).

Fig. 23.-Teeth of Dolium perdix.

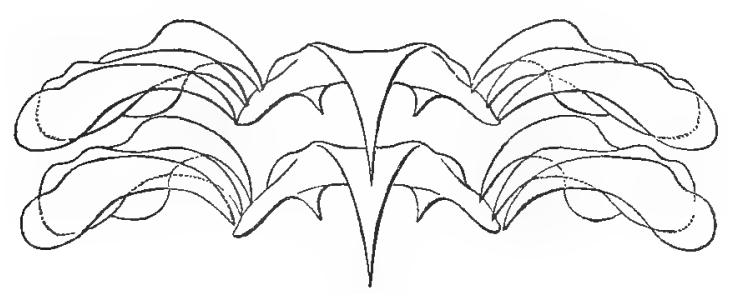

2. Malea.

Shell subglobose like Dolium, but outer lip thickened, toothed internally; pillar-lip thickened, with two or three very large ridges.

1. M. Pomum, t. 17. f. 2. Teeth —?, Adams, Gen.Moll.t.20. f.7.

The Malee live under and between stones at extreme low water mark.-C. B. Adams, 298.

\section{Ringicula.}

Shell ventricose; spire short; mouth contracted, with a notch in front; pillar-lip thickened, strongly plaited; outer lip thickened, reflexed. Eyes on the onter side of the base of the subulate tentacles. Operculum none?-Adams. Teeth —?

1. R. buccinea. 
Some authors have placed this genus with Auricula; but if the above description of the position of the eyes is correct, it differs from that family in that important character.

\section{Fam. XIV. TRITONIAD $\mathbb{E}$.}

Head truncated. Tentacles moderate. Mantle enclosed. Siphon of mantle straight. Operculum distinct, annular, ovate or triangular ; nucleus subapical, within the apex. Shell variced. Pillar veined or grooved. Canal straight. Mouth ovate.

M. d'Orbigny ( $C u b a, 160,167,168)$, not knowing the character furnished by the teeth, observes that Triton is only separated from Murex by conchological, and not by zoological characters; in the same manner he considers Fasciolaria and Pyrula as arbitrarily rather than as naturally separated from $F u s u s$; but all the three genera have most distinct zoological characters.

* Operculum as large as aperture of shell, ovate; varices rounded.

\section{Apollon.}

Shell ovate, compressed; varices two on each whorl, rounded, forming a border to the shell.

1. A. vexillum, t. 265 . f. 1 .

2. A. foliatum, t. $84 a$. f. 1 .

3. A. bufonium, t. 4. f, 2 .

4. A. graniferum, t. $4 . \mathrm{f} .4$.

5. A. leucostomum, t. 85. f. 1, t. 116. f. 2 .

6. A. reticulare, t. 86. f. 1 .

7. A. cælatum.

8. A. Rana, Adams, Gen. Moll. t. 11. f. 3.

The teetil of Apollon graniferum are peculiar, $3 \cdot 1 \cdot 3$; the central one is narrow, with two diverging branches, having a central elongated denticle, and a small lateral denticle in the middle of each side of each lateral branch; the inner? lateral compressed, with three or four denticles on its front edge; the outer lateral subulate, hooked (the teeth were not observed in position). The operculum is ovate, rounded at each end, with a marginal apical nucleus.

The Apollons live under stones below usual low water mark.

\section{Triton.}

Shell ovate; spire conic, with three varices on each two whorls, forming three interrupted longitudinal ribs on the shell.

1. T. nodiferum, t. 3. f. 3 б, t. 85 . f. 5 , t. 3. f. 4 ?

2. T. olearium, t. 3. f. 2 , t. 263 . f. 3 .

3. T. cutaceum, t. 3 . f. $1 \delta$. 
4. T. tuberosum, t. 4. f. $1-6$.

5. T. pileare, t. 4 . f. $3 \sigma^{\circ}$.

6. T. chlorostomum, t. 85. f. 2 .

7. T. cancellatum, t. 265 . f. 2 .

8. T. rubecula?, t. 85 . f. 3 .

9. T. Spengleri, t. 4. f. 5 .

10. T. album (Nassaria a.), Adams, Gen. Moll. t. 13. f. 1.

11. T. - ?, Middendorf, M. R. t.

The tentacles of Triton tuberosum are separate at the base; the proboscis is elongate. Teeth $3 \cdot 1 \cdot 3$; the central one with a central, large, and three smaller denticles on each side; the inner lateral tooth transverse, denticulated on its inner front edge; the two outer teeth subulate, curved. The operculum is ovate, rounded at each end, with a subapical marginal nucleus. The animal and teeth of $T$. subdistortum and $T$. chlorostomum were similar.

\section{Euthria.}

A Triton, with abortive or rudimentary varices. Canal elongate, rather bent up. Operculum ovate; nucleus apical.

1. E. lignaria, t. 89 . f. 3,9 .

** Operculum small, broad, subtrigonal; nucleus apical; varices acute, foliaceous.

\section{Persona.}

Shell ovate; spire conic, with three sharp-edged dilated varices on each two whorls ; aperture sinuous; lip veined. Operculum small, broad.

1. P. anus, t. 85 . f. 4.

2. P. cancellina, Adams, Gen. Moll. t. 11 . f. 2.

The head of Persona anus is truncate; the tentacles subulate; proboscis elongate. Teeth $3 \cdot 1 \cdot 3$; central with three small lateral and one much larger central denticle; the inner lateral transverse, dentated on the inner part of edge ; the two outer lateral conical, subulate, arched. The operculum triangular, as broad as long.

\section{Fam. XV. VERENAD五.}

Shell thin, ventricose, keeled, umbilicated. Aperture larger than the spire, compressed into a partial canal in front. Periostraca horny, rising into hairs at the angles of the shell. The axis placed considerably to the left of the canal. Operculum horny; nucleus on the front of the outer edge.

This family is the Buccinoid representative in this group. 


\section{VERENA.}

Character of the family.

1. V. borealis, Forbes \& Hanley, B. M. t. I.I. f. I.

"Central tooth of Verena borealis with the base wide, sublunate, the tip convex, narrow, cutting edge triangular, minutely toothed on each side, and with one sharp point ; lateral teeth, the first with the tip produced, serrated on both sides; second and third similar, claw-like, simple, slightly curved.",-Lovèn.

"Animal of Verena borealis with a short broad head, flanked by subulate tentacles set wide apart, bearing the eyes at the extremities of their thickened lower halves (or connate sustentacula); mouth inferior; proboscis long, retractile."-Forbes, p. 361.t. . Teeth $3 \cdot 1 \cdot 3$; central triangular, denticulated, with larger central denticles; lateral lanceolate; inner lateral denticulated on each end near the tip; outer simple (fig. 24).

Verena borealis lives in deep water; it is often obtained from the fish caught on the north coast of America.

This genus differs from Trichotropis in the animal having a proboscis instead of a rostrum (see that genus).

Dr. Lovèn refers Verena borealis to the Velutince, and Dr. Philippi refers it to the family Velutinacea (Handb. der Conch. 183).

B. Mantle siphoned, enlarged, produced over the shell. Shell channeled in front. Operculum none (p. 37).

\section{Fam. XVI. SYCOTYPID王.}

Head produced, conical. Tentacles small, near end of the head. Teeth $3 \cdot 1 \cdot 3$. Mantle enlarged, produced over the shell. Siphou of mantle and canal of shell straight, produced in front. Operculum none.

\section{Sycotypus.}

Shell obovate, thin, cancellated; spire short ; mouth large, tapering in front.

1. S. ficus, t. 86 . f. 2 , t. 261 . f. 4 ; Adams, Gen. Moll. t. 21 . f. 1 .

2. S. reticulatus, t. 261 , f. 5 .

C. Mantle not siphoned, more or less covering the shell; mouth of shell entire. Operculum none (pp. 37, 44).

\section{Fam. XVII. VELUTINIDAE.}

Foot moderate, rounded. Mantle very large, swollen and thickened on the edge, often partly covering the shell, with two emargi- 
nations, one branchial on the left, and the other anal. Proboscis elongate, cylindrical, annulated. Jaws two, horny. Tongue-membrane short. Shell thin. Aperture large. Operculum none.

* Shell short, externally spiral.

\section{Velutina.}

Shell spiral, cap-shaped, spirally grooved; aperture roundish; lips simple. Mantle edge slightly swollen. Foot rather long and wide, truncated in front; gills of two plumes, one of numerous striæe, the other inferior, small. Verge compressed.

1. V. lævigata, t. 103. f. 6, t. 109. f. 10; Forbes \& Hanley, B. $M$. t. O.O. f. 7, copied Adams, Gen. Moll. t. 21 . f. 2.

" Central tooth of Velutina haliotidea strong, subquadrate, transverse; cutting edge transverse, with one sharp point, toothed on both sides; first lateral tooth subquadrate, toothed on the margin with a larger pointed tooth, second

Fig. 25.

Velutina haliotidea.

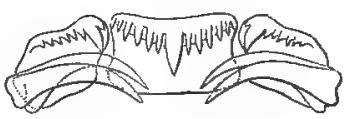
and third similar, claw-like, simple." (fig. 25)-Lovèn.

The foot of Velutina is lanceolate, moderate, double in front. Tentacles short, compressed, rather distant at their base, with a slight crest between them. Eyes on the outside of the tentacles near the base. Penis on the right side, large like that of Buccinum, with a subapical conical tip. Operculum none.

"Velutina lavigata inhabits deep water. The shell is covered with a rough epidermis, and the striæ constitute properly fine ridges, which are crossed by others less distinct; but when the epidermis is removed, it becomes smooth or faintly striolate, and the shell is then either pure white or pale rose colour. The animal is white, and entirely fills the shell. Tentacula two, tapering, short. Eyes on an enlarged space at the external base of the tentacula. Foot oblong, short, with plain margins; cloak plane, entire; above the outer tentaculum the male organ appears, in the shape of a short thick obtuse process."-Johnston, Berw. N. Club, i. 275.

\section{Morvillia.}

Shell ovate, orbicular, compressed ; spire conical ; whorls three or four; upper small, last very large, covered with a calcareous incrustation? Aperture ovate, very large, nearly the whole length of the shell; outer lip sharp and spreading; inner lip sharp-edged, margined with a flattened crescent-shaped opake white space. Operculum none. Tentacles thick, rather depressed, near together at the base. Eyes on the outer side near the base. Foot oblong. Mantle thickened within in front. Penis large, compressed on the base of the outer side of the right tentacle.

1. M. zonata (Velutina z., Gould, Mass. f. 160). 


\section{Marsenina.}

Body convex ; mantle edge swollen, covering the edge of the shell. Shell spiral, ear-shaped, the external part covered. Teeth $3 \cdot 1 \cdot 3$; central rather elongate, broad, with a reflexed denticulated tip ; inner lateral broad, with a triangular curved toothed tip, or outer lateral linear.-Berg, t. 4. f. 14, 15.

1. M. micromphala, Berg, Marsen, t. 4.

2. M. prodita. Lamellaria prodita, Lovèn.

3. ? M. plicatilis, Forbes \& Hanley, B. M.

t. O.O. f. 8 , foot produced in front.

"'The edge of the mantle of $M$.plicatilis is produced beyond and partly covering the shell."-Müller. (=Velutella, Gray.)

Fig. 26.

Marsenina prodita.

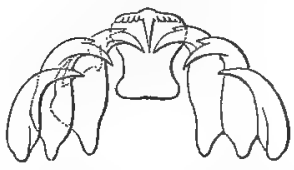

Central tooth of Marsenina prodita elevated, upper part rounded, wider; cutting edge transverse, with one sharp point, minutely toothed on each side; lateral teeth suberect, somewhat similar, clawlike; inner side of the first and second furnished with a minute tooth before the bend (fig. 26).

\section{** Shell internally convex, not spiral.}

\section{ONCHIDIOPSis.}

Body spherical, inflated. Shell internal, horny, not spiral. Teeth $3 \cdot 1.3$; central broad; apex reflexed, dentated; inner lateral broad, with an elongated reflexed toothed tip; two outer linear hooked.Berg, t. 2. f. $15,16$.

1. O. Groenlandica, Berg, Marsen, t. 2.

2. O. carnea, Berg, Marsen, t. 3.

D. Mantle not siphoned, enclosed. Mouth of shell entire in front. Shell sunk into the large foot of the animal (p. 37, 44).

\section{Fam. XVIII. NATICLD正.}

Foot very large, much produced in front, as if formed of four lobes, partly covering the shell, which is sunk into its substance. Mantle enclosed. Operculum spiral, horny, sometimes covered with a shelly external coat.

Foot folded, so as to form a round canal to admit the water to the gill-cavity on the left side of the shell.-See Foy, Bonite, t. 35.

Eyes, when present, immersed in the skin at the centre of the anterior base of the tentacles.

The gills consist of two plumes and some mucous fillets. Muzzle elongated, entirely retractile. Opercular mantle very large.

The trunk of Naticida is elongate, quite retractile. Tentacles united by a transverse membrane; eye-peduncles immersed at the outer base of the tentacles; chin very large; opercular lobe very 
ample ; mantle edge simple; lingual membrane short, linear; central tooth unidentate; lateral teeth $3 \cdot 3$; inner broad, toothed; two outer simple, hooked.

The animal of Naticida has a very large foot, elevated behind and enveloping a part of the shell, and produced in front, separated on the sides by a transverse groove.

Between the front lobe and the shell is placed the head, which is more or less hidden, broad and depressed, and provided with flat conical tentacles.-D'Orb. A. M. 400 .

Central tooth of Natica pulchella strong, wide at the base; lateral process on each side short, thick; cutting edge longly recurved, with three pointed lobes, the middle one largest; lateral Fig. 27.-Natica pulchella. teeth first stretched out at the tip and recurved, the middle point larger, the outer smaller and minutely denticulate within, second and third short, claw-like (fig. 27).-Lovèn.

The Natica are very voracious, and play a conspicuous part in devouring the dead fish and other animals thrown up by the tide. They have the power of perforating shells with a small round hole, and through the aperture they extract the juices and destroy the lives of the otherwise secure inhabitants.

Their font is very large, so as completely to envelope the object on which they prey. They burrow in the sand, so as to be almost entirely concealed by it, and their place is generally indicated by a small heap of sand.

The singular nidus in which the animal deposits its egg has been an object of much curiosity and speculation. It is a mass of sand glued together into the shape of a broad bowl, open at the bottom and broken on one side. The thickness is about that of orangepeel, easily bent without breaking when damp, and when held up to the light will be found to be filled with little cells arranged in quincunx order. Each of these cells contains a gelatinous egg having a yellow nucleus, which is the embryo shell. It is found plentifully about midsummer on every sand-flat where any species of Naticee resort. It has been considered as a coral, and called Flustra arenosa, Eschara lutosa, Alcyonium arenosum, and Discopora crebrum! -Gould, Mass. 233.

The small Natice are often found in the stomachs of fish.

Natica have been said to be without any epidermis (or periostraca), but this is an error; it is found on all these as on all other shells. Many Northern Natica even have a thick hard periostraca.

a. Naticina. 'Shell subglobose, solid; aperture moderate. Operculum large, horny, with a calcareous inner layer.

\section{Natica.}

Shell bemispherical, or half-ovate, solid ; spire short ; mouth halfovate; inner lip flattened. 
* Operculum flat, with many spiral grooves.

1. N. Canrena, t. 50. f. 2.

2. N. hebræa.

** Operculum flat, with two or three marginal grooves.

3. N. Marochiensis, t. 49 . f. 3 , t. 49 . f. 4 , t. 50 . f. 4 .

4. N. maculosa, t. 122 . f. 2.

5. N. clausa.

*** Operculum with a large convex ridge.

6. N. fulminata.

b. Neveritina. Shell subglobose, solid. Operculum large, horny, simple.

\section{Neverita.}

Shell depressed; spire depressed; mouth half-ovate; inner lip thickened, callous, with a central cross-groove.

1. N. glaucina, t. 12. f. 12 , t. 119 . f. 5 , t. 50 . f. $1,3,6$.

2. N. glauca, t. 120 .

3. N. Chemnitzii, t. 122. f. 6 ; Adams, Gen. Moll. t: 22. f. 3.

4. N. limbata, t. 118. f. 2.

5. N. sordida, Forbes \& Hanley, B. M. t. P.P. f. 3.

6. N. plumbea, t. 49. f. 2 .

7. N. monilifera, Adams, Gen. Moll. t. 22 . f. 2 .

8. N. Montagui, Forbes \& Hanley, B. M. t. P.P. f. 4.

9. N. Alderi, Forbes \& Hanley, B. M. t. P.P. f. 5.

Fig. 28.-Neverita Alderi.

10. N. Canrena, Forbes \& Hanley, B. M. t. P.P. f. 6.

The hinder part of the forehead of Neverita glaucina is elevated on the shell so as to hide the very small sessile eyes, which are situated at the base of the tentacula.-Joannis, Mag. Zool. Class. v. t. 37. When the animal withdraws itself into the shell, it contracts the foot, which emits a very large quantity of water from its gillcavities, or rather the aquiferous tubes. When the animal walks, it moves the front part of its enlarged foot almost from side to side like a feeler.

Foot of Neverita castanea very large, roundish-elliptical, thick, with very thin margins, rugose, with very large oblique undulated rugæ in its anterior half, its colour dull yellow. Head indistinct, broad; over the mouth a thin-edged rugose flap, having three rounded crenatures, and continuous with the tentacula, which are ráther small, rugose, much depressed or flattened, and taper to a fine point; externally of the tentacula, on each side, a thin rounded lobe, on which are placed in other species the eyes, of which, however, I 
cannot perceive any traces. Between the mouth and the foot, and parallel to the supra-oral flap, is a larger, thin, smooth, somewhat undulated flap, extending on each side nearly to the middle of the foot in a semicircular manner. The mouth small, proboscidiform, with a large roundish, bright red, lingual or pharyngeal mass. The mantle very thin, opening very widely in front, where it forms a thin, dense, yellowish flap, covering the branchial cavity, of which the surface is smooth; the branchia large. The intestine convoluted, terminating on the right side of the respiratory cavity; the liver dull olive, forming the last, very slender turns of the spire; the ovary pale yellow. -Macgilliv. Moll. Aberd. p. 346.

Lingual membrane of Neverita castanea linear, narrow, transparent in front, much dilated, half-ovate, rather acute in front, truncated behind. Teeth $3 \cdot 1 \cdot 3$, transparent; central rather broad, front edge very broad, produced on each side, apex recurved, with three rather large denticles, the central largest; inner lateral broad, the upper edge of the inner part recurved, entire; outer lateral small, subulate, curved, entire.

Animal of Neverita Alderi with a produced globular pink head (or proboscis?), having the mouth, which is longitudinal and pearshaped, in front, below which is a little foot-like process; jaws cartilaginous, square, toothed in front like a saw ; tongue like that of a Littorina, but shorter and broader in proportion; mouth pinkishwhite. Between the mantle and head is a sort of veil, which is furnished with two distant triangular tentacula, one of which is colourless, and the other pink, dark brown at the tip, but with no trace of an eye. Foot pinkish-white, its sides variegated brown.Forbes, l. c.

M. Deslongchamps describes the mantle of Neverita castanea as very large, covering and entirely hiding the shell, like that of Cypraa, but he observes that it is only the right side of the mantle that is produced over the shell; the head and neck are very large, and when all the parts are well developed, the animal has the general appearance of Bullae aperta.-Bull. Sci. Nat. 1825, x. 296. He appears to have mistaken the foot for the mantle.

\section{Polinices.}

Shell half-ovate, solid; spire conical; mouth half-ovate; inner lip depressed, with a slight central cross-groove.

1. P. mammilla, t. 50.f. 5, t. 122. f. 3. (Ruma m.), Adams, Gen. Moll. t. 22, f. 6 .

2. P. chrysostoma, t. 122. f. 1 .

3. P.? Uber, $D^{\prime}$ Orb. Voy. A. M. t. 55. f. 12, 13.

\section{Mammilla.}

Shell ovate; spire conical; mouth large, open; inner lip rather thickened, reflexed. Operculum large, thin. 
1. M. melanastoma, Adams, Gen. Moll. t. 22 . f. 5, t. 49. f. l.

2. M. melanastomoidea, t. 49 . f. 5 .

3. M. fibrosa, t. 122 . f. 4 .

c. Shell subglobose, solid; aperture moderate. Animal and operculum unknown.

\section{Cervina.}

Shell subglobose, solid, polished, imperforated; mouth semi-ovate ; inner lip callous, rounded.

1. C. fluctuata, Adams, Gen. Moll. t. 22. f. 4, shell only.

\section{Naticina,}

Shell ovate; whorls striated; axis perforated; spire short; mouth ovate, longitudinal. Allied to Stomatia?

1. N. papilla, Adams, Gen. Moll. t. 22. f. 7, shell only.

d. Shell ear-shaped, thin; aperture very large. Operculum very sinall, rudimentary, horny. Animal: foot very large, tonguelike, often retractile into the shell.

\section{Stomatia.}

Shell depressed, ear-shaped; spire small ; mouth very large, open ; inner lip thin, slightly reflexed.

1. S. Haliotoideum, t. 119. f. 3. (Catina Leachii), Adams, Gen.Moll. t. 22 . f. 8 .

2. S. zonalis, t. 49 . f. 6 , ?t. 82 . f. 2 .

3. S. Cymba, t. 119 . f. 3, t. 118. f. 1 .

4. S. lævigata, t. 122. f. 5.

5. S. Reevesii, t. 121 .

6. S. Leachii, Adams.

The animal of Stomatia only differs from Natica in being much larger in respect to the size of the shell, and in being provided with only a small ovate, horny operculum. The size of the animal differs in various species; thus, in $S$. Cymba it is capable of being withdrawn into the cavity of the shell, which is not the case with $S$. $H a$ liotoideum.

Stomatia Cymba is very common on the sandy coast two or three yards below the lowest tide; when walking, it elongates and contracts the front part of its foot; only a part of the shell is exposed.

Stomatia differs from Natica in the small size of the operculum, which escaped the observation of $\mathbf{M}$. de Blainville, but which is very distinctly to be seen in both the specimens he described in the $\mathrm{Mu}$ seum. Blainville described the shell as covered with the mantle, but the mantle is enclosed and the shell is sunk in the foot.-Gray, Spic. Zool. ii. 183. 


\section{Amaura.}

"Animal allied to Natica; foot small, compact, without any posterior lobe; the front lobe deeply sinuated. Eyes subcutaneous, situated at the intermal base of the lobe. Operculum terminal, fewwhorled, horny, thin. Shell ovate, imperforate, small; spire produced; mouth reversed pear-shaped, about half the length of the shell."-Möller, Moll. Groenl. 1842, 7.

1. A. candida, $l, c$.

\section{Fam. XIX. NERITOPSID疋.}

Animal unknown. Shell semiovate, solid, white, spirally ribbed, nodulose, imperforated. Mouth ovate; inner lip rather flattened, transverse, with a broad central notch. Operculum — ?

\section{Neritopsis.}

Character of family.

1. N. radula.

E. Ptenoglossa. Teeth in numerous longitudinal series.

* Mantle and mouth of shell angular in front and rather siphoned. Operculum none (or vesicular?).

\section{Fam. XX. IANTHINID A.}

Head small, with a short inflated retractile proboscis. Teeth in numerous diverging transverse series (fig. 29). Eyes none. Tentacula bifid. Gills double, one with two ranges of lamellæ and with

Fig. 29.--Teeth of Ianthina fragilis.

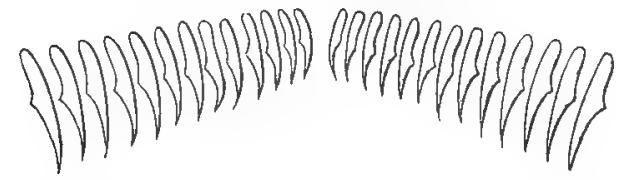

rudimentary mucous filaments. Foot small, flat, with a vesicular appendage on the hinder part of the under side. Body and shell spiral. Hermaphrodite, self-impregnating? Eggs contained in a vesicular mass attached to the foot, like Capulus.

\section{InNThina.}

Mantle lax, swelling beyond the edge of the shell, and forming an incipient canal. Tentacles short, conical, pointed, deeply cloven. Eyes obsolete. Foot truncated in front.-Clark, Ann. \& Mag. N, H. $1853,47$. 
Shell subconic, thin, last whorl ventricose, subangular; mouth large, subangular in front; pillar straight, rather produced.

1. I. vulgaris, t. 48 . f. $1,5,6,7$, t. 117 a. f. 2,4 , t. 48. f. 2 .

2. I. nana, t. 48 . f. 3,4 .

Fig. 30.-Ianthina fragilis.

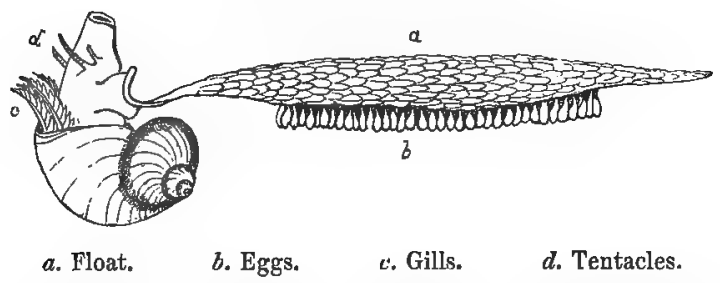

Foot folded on itself transversely, with the hinder part separate (part of the back?), bent up, thickened, and bearing the vesicular float (operculum ?) (fig. 30). Tentacles and eye-pedicels low down, and placed on the ventral side (above when floating) of the very large exsertile trunk. Operculigerous lobes large, broadly dilated to the end of the foot.

The shells of young Ianthina are very blunt, very smooth, shining, with three continuous whorls.-D'Orb. Cuba, 80 .

\section{Recluzia.}

"Animal allied to Ianthina, and furnished with a vesicular float."

Shell oval or oblong, bucciniform, thin, whitish, covered with a brown periostraca; spire elongate; whorls ventricose, last longer than the spire; aperture ovate, oblique, rather effaced in front; margin disunited; lip oblique, rather sinuous in the middle; outer lip acute, entire. Operculum none.

1. R. Jehennei, Petit De la Saussaye, Journ. Conch. 1853, 117. t. 3. f. 3. From Arabian Gulf.

2. R. Rollandiana, t. 3. f. 12 . From Mazatlan.

* Mantle and aperture of shell entire. Operculum spiral, horny.

Fam. XXI. SCALARIAD无.

Shell turrited; whorls variced; mouth entire. Operculum horny, spiral.

Gills a single branchial plume, with some mucous fillets. Mantle fleshy, reflexed on the varix, forming a short, lax branchial fold corresponding with the incipient canal of the shell. Head short, crescent-like; proboscis strong, fleshy. Tentacles subulate. Foot extended in front; hinder part with a deep longitudinal groove. Teeth in many series, uniform, hook-like, the outer rather larger (fig. 31). Animals emit a quantity of purple fluid. 


\section{Scaldria.}

Shell turrited; spire with regular varices; aperture roundish; lip reflexed, forming varices.

1. S. clathrus, t. 127 .

2. S. psendoscalaris, t. 127 . f. 8 .

3. S. Trevelyana, Forbes \& Hanley, B. M. t. F.F. f. 1, 2, 3, figured as if it had a tapering rostrum! and distant lateral tentacles. -Adams, Gen. Moll. t. 23. f. 8.

Cirsotrema, Morch, has distant rounded varices, with thin intermediate concentric lamellæ.

C. varicosa, Adams, Gen. Moll. t. 23. f. 9.

Fig. 31.-Scalaria Turtoni.

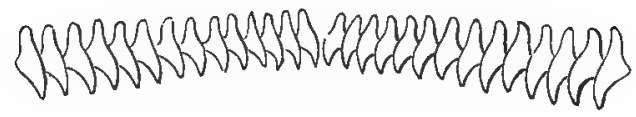

The foot of Scalaria Gronlandica is short, thick, nearly quadrangular. Head elongated, rounded superiorly, not separated from the neck by any distinct line. Tentacles two. Eyes small, at the outer base of the tentacles. Mouth rather large, rounded, corrugated. Operculum horny, strong, opake, of few whorls. It is sluggish in its movements, and feeds eagerly upon fresh beef, especially if somewhat macerated.

The teeth of Scalaria Trevelyana are numerous, in an angular cross line, and the prehensile collar is very distinct.-Alder.

The head of Scalaria pseudoscalaris is obtuse, rather prominent, with an elongated subcylindrical proboscis. The gill is single, pectinate. The foot oblong, truncated, and angulated in front.

The hinder half of the sole of the foot of Scalaria clathratulus is grooved longitudinally and medially by a deep central depression.Alder. The mantle forms a distinct fold opposite the lower angle of the mouth of the shell. The foot is varrow, obtusely triangular, and often carried considerably in advance of the head.-Forbes.

The shells of Scalaria elegans are collected by the Spaniards at St. Blas to form ear-rings; they are called Caracoles finos. The English species are also used as ornaments.

\section{Tribe II. Iniophthalma, Gray.}

Eyes sessile, on the back of the head, between, and often behind the base of the tentacles. Operculum horny, spiral or annular (p. 10).

In the young shell the first whorl is placed across the others, and this character is often to be observed on the apex of the adult shell. 
A. Ptenoglossa. Teeth in numerous longitudinal series (fig. 33).

\section{Fam. XXII. ACTEONID正.}

Shell spiral, ovate, external. Teeth numerous, uniform, in a diverging transverse series as in Bulla (fig. 33). Tentacles broad, depressed, united, and forming a shield on the head, notched in front. Eyes on the inner side of the base of the expanded tentacles. Foot moderate, dilated and partly reflexed on the sides. Mantle enclosed; "branchial plume single." Operculum horny, ovate, spiral ; few whorls, with a thin flap on the inner edge.

This family has many affinities to Bullida; indeed it may prove to be part of that family.-Phil. Moll. Sicil. ii. 143. Alder and others have placed Acteon in that family.

\section{Acteon.}

Shell thin, ovate, spirally striated; spire short, acute; mouth lanceolate, narrow, rounded, and entire in front; inner lip thin; pillar with a single oblique spiral fold. Operculum subspiral, horny. 1. A. Tornatilis, t. 128. f. 5 ; Forbes \& Hanley, B. M. t. V.V. f. 7.

The body of Acteon is spiral and compressed; the edge of the mantle free all round, slightly nicked in front, and with a slight fold on the right side. The head is surmounted by two very broad, thin,

Fig. 33.-Teeth of Acteon Tornatilis.

Fig. 32.-Acteon Tornatilis.
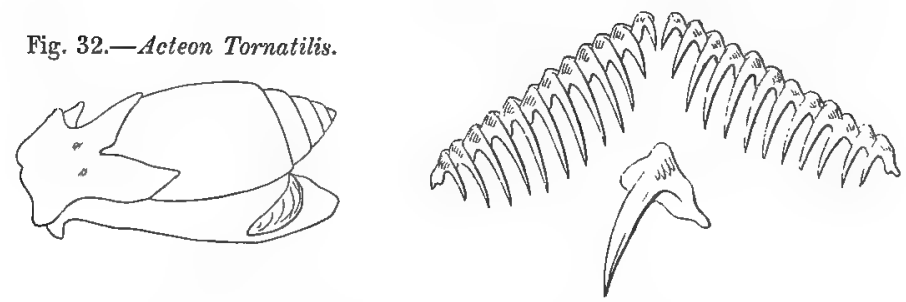

expanded, membranaceous tentacula, forming a kind of hood, and separated from each other by a longitudinal groove; each of them has a slit near the middle of its outer margin, the upper edge of the left being expanded and rounded, while that of the right is much larger, acute, and folded down. These tentacula bear some resemblance to the double fringed lips of Phasianella (see Cuv. Moll. t. 11. f. 2, 3). Head distinct. Eyes —? Mouth sunk in. Foot short, folded across near the anterior part when the animal is contracted, slightly nicked anteriorly and rounded behind. The animal is unisexual. The penis exserted, large, situated near the base of the right tentaculnm. Branchia pectinate. Operculum horny, exactly the same shape with the mouth of the shell, attached to the upper 
part of the back of the foot, short, truncated, sickle-shaped, thin and pellncid, formed of somewhat concentric striæ; the inner front edge is thickened, and the whole of the inner edge, together with the lip, is furnished with a thin membranaceous expansion, which is much broader at the two ends. The use of this thin edge is doubtless to enable the animal to adapt its operculum more exactly to the shape of the mouth of the shell. It has been observed that shells with a toothed columella never have opercula, but many instances may be adduced to the contrary. Trochus Pharaonis is not distinguished in this respect from the other shells of that genus, and the genera Turbinellus, Fasciolaria and Pyramidella are all furnished with opercula.-Gray, Spic. Zool. ii. 183. This description of the animal was from a specimen long kept in spirits. Mr. Alder calls the tentacula the disk.

"Tornatella. Animal Bulla est, et ab illo B. striata parum differt. Pes oblongus, testa parum longior, antice truncatus angulis recurvis uncinatis, postice obtusus, supra operculum parvum ; apertura longe minus, oblongum, corneum gerit, qui striis incrementi cum Murieum, \&c. operculo convenit. Caput depressum, sulco profundo a pedo divisum, cum tentaculis coalitum, antice paullo dilatatum, medio excisum, superne sulco mediano longitudinali divisum, postice in lobos duos acutos, lanceolatos, supra testam usque ad medium ejus reflexos terminatum. Oculi duo parvi in medio capite. Color animalis albus."-Phil. Sicil. ii. 143, 1844; Wiegm. Arch. 1841, 55. t. 5. f. 10 (and Chiaje, t. 77. f. 13).

The animal of this genus (Acteon) comes very near to that of Bulla, having a broad lobed disk in front, without tentacles. We find too that the branchial aperture is lateral, the cloak being closed across the front, and open only on the right side, which further confirms us in assigning it a place in this Order (Tectibranchiata). The operculum can scarcely be consiclered of more than generic importance.-Alder, Cat. Moll. N. 29.

\section{Solidula.}

Shell thick, solid, ovate, spirally grooved; spire conic, acute; aperture longitudinal, narrow, entire, and rounded in front; imner lip callous; pillar with two plaits, the anterior grooved and continued into the outer lip. Operculum transverse, elongate, curved, imbricate ; scar linear. Animal —_ ?

1. S. nævia.

\section{Monoptygma.}

Shell subulately turrited, spirally striated; apex simple, acute; aperture oval, larger than wide, rounded and entire in front; columella with a single oblique fold.

1. M. striata, Gray, P.Z. S. 1851, 222.

It differs from Acteon in being elongated, and in having an oblique fold instead of a transverse plait on the columella.-Adams. 
B. Tænioglossa. Teeth in seven longitudinal series, $3 \cdot 1 \cdot 3$. Tentacles cylindrical (p. 54).

\section{Fam. XXIII. CERITHIOPSID无.}

Eyes on the upper inner base of the tentacles. Tentacles close together in front, cylindrical. Proboscis —? Foot elongate, much produced and double-edged in front, tapering behind. "Teeth $3 \cdot 1 \cdot 3$; central large, bifid; lateral linear."-Alder, MSS. Operculum annular, nucleus apical.

\section{Cerithiopsis.}

Shell turrited; mouth ovate; canal short, open, rather bent up. Operculum ovate, triangular, apex acute.-Adams, t. 25 . f. $5 a$.

1. C. tubercularis, Forbes \& Hanley, B M. t. O.O. f. 1, 2; Adams, Gen. Moll. t. 25. f. 5.

Head rather broad and short, flanked by two obtusely subulate tentacles, widening slightly at their bases, with more slender flat tips. Eyes rather close together, towards the centre of the tentaclebase. Mouth inferior, furnished with a retractile proboscis. Tongue armed with teeth, which appear to resemble in their arrangement those of Trichotropis. Mantle not reflected, furnished with a rudimentary siphonal fold (not extended beyond the shell). Foot obloug, subquadrate in front, where it is furnished superiorly with a mentum, obtuse behind, grooved for half its length below, the groove terminating in a perforation. Operculigerous lobe well developed. Operculum corneous, of concentric elements; nucleus terminal. Shell like Cerithium.

Teeth of Cerithiopsis tubercularis $3 \cdot 1 \cdot 3$, in seventy cross rows; central tooth broad, ovate, with two small divergent apical teeth; lateral all similar, elongate, hooked at the tip. Operculum oblong, rather more angular at the hinder end; subannular nucleus small, on the front inner side.

The foot of Cerithiopsis is usually carried in advance of the tentacles; there is a distinct margined operculigerous lobe without wings or caudal appendages.

The Cerithiopsis inhabits quiet sheltered pools on the shores among the minor Algæ, and it is very lively. There can scarcely be a greater contrast than between it and Cerithium reticulatum, which has the entire aspect of an elongated Rissoa, whereas this is an undoubted Canalifer, with evident relations to Eulima and Chemnitzia. -Clark, 492.

Mr. Stimpson, from the examination of the animal, refers Cerithium terebrale and $C$. Emersonii, Gould, to the genus Cerithiopsis. -Stimpson, Test. N. Eng. 45.

Mr. Forbes refers this genus to the family Cancellariada with Trichotropis.-Brit. Moll. ii. 364. 
C. Gymnoglossa. Teeth none. Tentacula folded (p. 54, 56).

Fam. XXIV. PYRAMIDELLID $\mathbb{E}$.

Shell turrited; nucleus and apical whorls reversed, transverse. Mouth moderate; pillar-lip plaited. Operculum horny, spiral, of few whorls, with a thin flap on the inner side. Tentacula broad, folded. Eyes sessile, on the outer side of the base of the tentacles. Foot moderate. Mantle enclosed. Teeth none or rudimentary.

a. Shell free; pillar-lip plaited. Operculum spiral.

1. Овeliscus.

Shell turrited, spiral ; cavity marked with internal varices; mouth ovate; outer lip often toothed; pillar with three or four oblique plaits in front. Operculum half-ovate, subspiral, with a notch.Adams, Gen. Moll. t. 24. f. 5 a.

1. O. maculatus, t. 123. f. 13 .

2. O. ventricosus, t. 123 . f. 10,12 .

\section{Pyramidella.}

Shell turrited. Operculum narrow.-Adams, Gen. Moll. t. 24. f. $4 b, c$.

1. P. auris-catti, Adams, Gen. Moll. t. 24 . f. 4.

\section{Odostomia.}

Shell turrited; month ovate; pillar lip with a single oblique plait in front.

1. O. spiralis, t. 125 . f. 4 (" not correct," Alder), t. 128 a. f. 3 ; Forbes \& Hanley, B.M. t. F.F. f. 8, 9 .

2. O. interrupta, t. 128 a.f. 4 .

3. O. clavula, t. 128 a. f. 2.

The animal of Odostomia spiralis is white, and has the tentacles ear-shaped or longitudinally folded, with the eyes at the internal base. Characters as in the genus Chemnitzia. The figure given in the Annals of Nat. Hist. xiil. t. 8. f. 13, is deficient in not displaying this character ; from the minuteness and transparency of the animal, the folds of the tentacles can only be seen in a favourable light.Alder, Cat. Moll. N. 52, 1848.

Animal of Odostomia strong, depressed. Head broad. Tentacles ear-shaped, externally channeled in front; hinder lamella more or less produced on the nape; front one thin, often connate, with the opposite one before the eyes. Eyes large, immersed without bearer between the base of the tentacles. Proboscis retractile under the base of the tentacles when evolved, broader than the nape, as long or longer than the foot, round, attenuated at the end. Mouth minute, edentulous? Chin elevated, separate from the foot, broader above. 
Foot broad, depressed, truncated in front, sharp, angulated or nicked, vibrating, narrow in the middle, tongue-shaped behind. Operculigerous lobe moderate, with a conical appendage at each side. The mantle with a thin, tongue-shaped, channeled process on the right. -Lovèn, Moll. Scand. 18, 1846.

As the apex of the young shell of Odostomia in the egg is heterostroph, it might be supposed that the adult would be liable to be twisted in this manner, but this is not the case. Mr. Jeffrey has justly remarked (Ann.\&.Mag. Nat. Hist. ii. 1848, 333) : "Although I have examined many hundred specimens of Odostomice from almost every part of the kingdom, I have only once met with a reversed shell, and which I referred to the Turbo lavis of Walker (f. 35); but the specimen was unfortunately broken, after having been many years in my cabinet. I considered it to be a monstrosity of Odostomia pallida."

\section{b. Shell free; pillar-lip smooth.}

\section{Chemnitzia.}

Head broad, bilobed in front; proboscis elongate; tentacles flattened, tapering, triangular or ear-shaped; eyes on the inner side of their base; foot short, triangular, lanceolate, with a distinct fold or mentum in front. Shell turrited; whorls many, striated and crossribbed, opake; apex sinistral, heterostroph; aperture oblong or subquadrate; iip thin; pillar-lip straight. Operculum horny, subspiral.

1. C. rufa, Forbes \& Hanley, B. M. t. F.F. f. 4.

2. C. scalaris, Forbes \& Hanley, B. M. t. F.F. f. 5. Turbonilla s., Adams, Gen. Moll. t. 24. f. 6.

3. C. rufescens, Forbes $\&$ Hanley, B. M. t. F.F. f. 6.

4. C. MacAndrei, Forbes \& Hanley, B. M. t. F.F. f. 7. Eulimella Scillæ, Adams, Gen. Moll. t. 24. f. 8.

Animal of Chemnitzia nivea white; head short; tentacles triangular, very broad, with the eyes at nearly the middle of their bases; foot elongate, with an acuminated indentation at the anterior extremity.-Stimpson, Test. N. Eng. 40.

Chemnitzia MacAndrei and C. acicula have been referred to $E u$ lima. Professor E. Forbes has more recently proposed for them the genus Eulimella, but we prefer considering them to belong to Chemnitzia, from which they only differ in the more polished surface of their shell. The apical nucleus and the form of the aperture indicate their place in this genus, independently of the animal, which, according to our observations, is essentially the same in each.-Alder, Cat. Moll. N. 50.

Chemnitzia. "Animal illi Eulimarum simillimum, sed proboscidiferum; sic describitur: Animal corpore admodum spirali, pallio simplice, ecanaliculato; pede antice abrupte truncato, postice attenuato, exappendiculato, operculifero ; tentacula duo triangularia (triquetra), s. prismatica, basi coalita, oculis sessilibus, superne ad basim internam (?) positis, approximatis. Buccæ lahiales conlitæ, infra tenta- 
cula exserta, proboscidem abbreviatam, depressam, profunde emarginatam seu bilobam referentes. Operculum corneum, tenue, ovatum, integrum (paucispiratum? simplex ?)."-Philippi, Sicil. ii. 136.

Animal of Chemnitzia simillima white. Tentacles blunt, lanceolate, broad, set far apart. Foot oblong, truncated, tapering behind. Mentum two-lobed.-Forbes.

The retractile proboscis of the Chemnitzice is very rarely evolved. The orifice of the rostrum is not precisely in the position of the proboscidal fissure in Muricida ; it is not quite so low in the fork, though exactly under the tentacula at the point of the invasion of the neck, and its continuation the rostrum, by those organs.-Clark, 398, 399.

Eulima and Chemnitzia.-Lingual siphon very long, flat, unarmed, quite smooth ; the inner cylinder has the appearance of a shagreened, roughened portion, like the prehensile collar of Buccinum.-Clark.

Operculum of Chemnitzia horny or subtestaceous, suboval, subspiral; the lower area under the nucleus furnished with an apophysis.Clark.

The branchial plume of Chemnitzia Gulsonce is narrow, arcuated, of about 15-18 rather coarse opake strands, with the heart and auricle at the posterior end.

The rostrum of Chemnitzia plicata is long, presenting at its termination a subcircular or squarish flat disk; it issues from under the coalition of the tentacular membranes, and is attached to the foot by a bridle; the fissure of the retractile proboscis is at the upper basal portion of the rostrum just below the eyes.-Clark, Moll. 522, App.

The tentacula of Chemnitzia clavula are extraordinarily short and broad, in consequence of the auricular portions that spring from their external margin unfolding and forming a large, fine, arcuated membranaceous leaf.

Mr. Clark observes : Chemnitzia acuta shows in a marked manner that the rostrum or mentum is really the head of the animal; it is channeled from its termination to its base, at which point, between and just under the eyes, the fissure is evident, from which is evoluted a long proboscis. The anteal portion of the rostrum is without any sort of orifice, but it is probably a tentacular aid, and also one of progression.-Moll. 522 .

\section{Eulima.}

Shell turrited, thin, polished externally. Mouth ovate ; outer lip rather sinuous; pillar lip simple, rather thickened. Operculum half-ovate.-Adams, Gen. Moll. t. 25. f. 1 b. Tentacles elongate, nearly united at the base.

Animal creeps with the foot greatly in advance of the head, which is almost always concealed beneath the edge of the aperture of the shell, the tentacles alone protruding.

1. E. distorta, t. 125. f. 11 ; Forbes $\$$ Hanley, B. M. t. K.K. f. 4.

2. E. polita, t. 125 . f. 12 ; Forbes \& Hanley, B. M. t. K.K. f. 3.

3. E. grandis, Adams, Gen. Moll. t. 25. f. 1 . 
In Eulima polita the animal is white, except the tentacles and margin of the mentum, which are deep golden-yellow. The liver, as seen through the shell, is green in $\boldsymbol{E}$. distorta, and purplish in E. polita.-Alder, Cat. Moll. N. 47.

These are the prevailing colours of the genus, but the disposition of them is different in different species, and appears to be sufficiently permanent to be taken as a specific character.

The animal of Eulima distorta has two long subulate tentacles, with very large eyes at their posterior base. The foot is slender, much produced in front, and has a bilobed flap (mentum of Lovèn) on its upper surface. The body is yellow, beautifully variegated with carmine, which forms an irregular band on each side; the tentacles and foot white.

The animal of Eulima oleacea is white, hyaline. Tentacles almost joining each other at their bases, where on the exterior sides are the eyes, which may be seen through the shell when, as is usually the case, the head does not project beyond it. Foot short, broad, slightly produced at the anterior angle, the lobe above projecting rather beyond it.-Stimpson, Shells $N$. Eng. 40.

The proboscis of Eulima polita has' a very long unarmed lingual riband, without the least appearance of spinous processes.-Clark, Moll. 449.

The retractile proboscis of Eulima is very similar to that of Chemnitzia; it consists of two retractile tubes, an inner and an outer one, as in Murea undatus. Though the long flat tongue appears quite smooth, there is nevertheless, in the inner cylinder, the appearance of a shagreened, roughened portion, which may be tantamount to the denticular portion of the inner tube of Murex undatus.-Clark, Moll. 449.

The verge of Eulima polita springs under the right tentaculum; it is rather long, flat and falcate at the end; branchial plume single. The Eulime are extremely free and vivacious; they delight in swimming, and march with celerity._Clark, Moll. 450.

What has been called the mentum in Eulima is an integral part of the disk of the foot. Lovèn does not mention one.-Clark, 449.

\section{Nisso.}

The shell differs from Eutima in the axis being umbilicated. Operculum half-ovate-Adams, Gen. Moll. t. 25. f. 2 .

1. N. terebellum.

\section{Leiostraca.}

Shell subulate; whorls many, flat, polished; outer lip simple, acute; pillar lip smooth, axis imperforated. Mouth ovate, narrow. Operculum horny.

Tentacles two, long, subulate, close together at their base, with the eyes immediately behind them. Foot extended in front, with a bi- 
lobed flap on the upper surface in front. Head seldom protruded beyond the transparent shell.-Alder.

1. L. bilineata, Adams, Gen. Moll. t. 25. f. 3. Eulima b., Forbes \& Hanley, B. M. t. K.K. f. 5.

\section{Menestho.}

"Animal : Foot elongate, narrow. Mouth simple; lingual membrane none. Tentacles short, thick. Eyes small, at the inner base of the tentacles. Operculum few-whorled. Shell conical, turrited." -Moller.

1. M. albula, Moller, MSS., cop. Gray, Fig. Moll. t. 125. f. 2, \& Adams, Gen. Moll. t. 24. f. 10.

\section{ACLIS,}

Shell turrited; whorls many, convex, striated. Mouth oval or rounded; pillar lip without folds ; axis perforated or subperforated.

1. A. supernitida, Forbes \& Hanley, B. M. t. M.M. f. 5, \& Adams, Gen. Moll. t. 24. f. 9.

Animal of Aclis supernitida slender, head truncate. Tentacles slender, cylindrical, rather inflated at the tip, close at the base. Eyes immersed, basal, rather lateral. Proboscis long, strong, retractile. Tongue armless. Chin free. Foot very narrow, produced. Operculigerous lobe unequal, right side larger, three- or four-plicate, left side with a rounded lobe. Operculum — ?-Loven.

The animal of Aclis supernitida with an elongate produced mentum, rather enlarged, truncated at the end. Tentacles two, lateral, far back. Eyes on the inner side of the base of the tentacles, seen through the shell.

\section{Hyala.}

Shell subcylindrical ; whorls rounded, last very large ; axis imperforate; outer lip acute. Animal : muzzle bilobate. Tentacles subulate, flattened, blunt. Eyes small, basal, superior, and central. Foot broad, two-lobed in front. Operculum roundish, thin.

1. H. vitrea (Risso v.), Forbes \& Hanley, B. M. t. M.M. f. 6 ; cop. Adams, Gen. Moll, t. 34. f. 7 .

c. Shell living in holes in starfish or on spines of Echini. Operculum none?

\section{Stylina.}

Shell subglobose, thin, smooth, polished; whorls many; apex acuminated, produced, styliform; mouth rather large, subovate, rounded before; pillar lip thin, curved, smooth.

Tentacles slender, cylindrical, with the small immersed eyes at their external bases. Mantle thick, fleshy, reflexed on the last whorl of the shell. Foot large, long, tongue-shaped, produced into 
a conspicuous mentum in front. Tongue unarmed. A single branchial plume.

1. S. ovoidea, n. s. t. 126 a. f. 3 ; Adams, Gen. Moll. t. 25. f. 4 .

2. S. - n. s. t. 126 . f. 5.

3. S. Turtoni, Forbes \& Hanley, B. M. t. O.O. f. 5.

In the original description of the animal the contracted foot appears to have been described as the mantle partly covering the shell.-Sow. Genera, t.

The animal of Stylina Turtoni is white, with a rather large foot, without any operculum, a round head with two cylindrical tentacles, and minute eyes at the external or posterior base. No portion of the shell was covered with the fleshy part, but I am not certain that in a state of vigour the animal has no power of extending some part of the mantle or foot over it. The animal has much the appearance of an Eulima. It has no large anterior disk, like Natica. The remains of the animal examined under the microscope did not show any denticulated tongue.-Alder, Cat. Moll. Newc. 46.

Otolites of Stylina Turtoni circular, with a central dot. Gills? a single series of triangular lobes. No lingual band visible in the two specimens I have examined. Mouth breaks up into squarish angular fragments, not crystalline, perhaps horny.-Alder, MSS.

Like Eulima the shell is often curved. Some species appear to live attached to the spines of Echini, while others are only found imbedded in the substance of starfish.

The Stylina stylifera of Macgillivray is described from the shell of a young exotic Bulimus.-Jeffreys.

\section{Entoconcha.}

"Shell obovate, smooth; whorls very rapidly enlarging; spire short, very blunt, tip not produced; aperture transverse, semilunar, angulated above, rounded beneath, margin disunited; pillar edge straight; mouth nearly as long as broad. Operculum not spiral."

1. E. mirabilis, J. Müller, Berlin Acad. 1852 ; Zool. Arch. 1853, 102.

Living in Synapta digitata.

\section{Fam. XXV. ARCHITECTOMID E.}

Shell conical, depressed, having an umbilicated axis. Foot moderate, for walking. Tentacula near together, nearly united at their base, over the retractile trunk, grooved beneath. Gill-cavity divided by a longitudinal fold.

\section{Architectoma.}

Shell conical; whorls few, square. Operculum ovate, flat, fewwhorled.-Adams, Gen. Moll. t. 25. f. $6 a, b$. 
1. A. perspectira (Solarium p.), Quoy, t. 41. f. 5; Eydoux, t. 126.

f. 2 ; Adams, Gen. Moll. t. 25. f. 6 .

The foot of Architectama perspectiva is very large, broad, folded together on each side in the front half; the front edge truncated, double-edged, rather produced, acute on each side of the front. Tentacles two, conical, close together at the base, with a longitudinal groove on the under side to the apex. Eyes on the upper part of the outer side of their base. Proboscis very long, cylindrical, completely retractile. Teeth none?

\section{Torinia.}

Shell conical; whorls square. Operculum circular, elevated, conical, of many whorls.-Adams, Gen. Moll. t. 25. f. $7 a, b, c$.

1. T. cylindrica. Solarium variegata, Quoy, t. 41. f. 3; Adams, Gen. Moll.t. 25. f. 7.

The tentacles of Torinia straminea conical, rather thick, close together at the base. Foot small; angle of the front edge rather produced, conical. Operculum thick, horny, yellow, circular, as large as the mouth of the shell, concave externally, annular, formed of several concentric circles; the inner smaller, most distinct; the outer edge thinner; inner side convex, with a large central conical and more flexible thick yellow Fig. 34. process, half as long as the diameter of the operculum, with a rather acute tip (fig. 34).

\section{Bifrontia.}

Shell discoidaI; whorls square, last produced, separate. Operculum like Torinia.-Adams, Gen. Moll. t. 25. f. y b.

1. B. Zanclea (Omalaxis Z.), Adums, Gen. Moll. t. 25. f. 9 (shell and operculum only).

\section{Fam. XXVI. TYLODINAD虑.}

Shell conical, depressed; cavity very broad, simple. Animal like Odostomia. Teeth — ?

\section{Tylodina.}

1. T. punctata, t. 103 . f. 7.

2. 'T. citrina, t. 103 . f. 1 .

Lovèn describes the body of Tylodina Duebenii as oblong, without any rostrum. Chin deeply cut; lobes lanceolate. Tentacles earshaped. Gill dextral. Anus behind, subtubular. Foot strong, thick; sole ovate. Shell ovate, depressed, conical, obsoletely radiated; apex with two reversed sinistral whorls. Lovèn observes that this genus has the same alliance to Odostomia as Emarginula to Trochus. 


\section{Suborder III. Rostrifera, Gray.}

Head moderate, with a more or less elongated, produced, contractile, transversely annulated rostrum. Tentacles subulate, far apart on the sides of the base of the rostrum. Eyes on the outer side or behind the base of the tentacles. Teeth on an elongated, linear, lingual membrane, partly received in the visceral cavity, in seven series, $3 \cdot 1 \cdot 3$; the central and inner lateral fixed, with a broad base; the two outer lateral versatile, suberect; the upper edge lobed.

Phytophagous.

I. Platypoda. Foot depressed, expanded : for crawling.

$a$. Eyes pedicelled.

$b$. Eyes sessile, basal, exterior.

c. Eyes sessile, basal, interior and posterior.

II. Protopoda. Foot roundish, truncate or clavate.

III. Leptopoda. Foot compressed: for leaping.

$a$. Eyes pedicelled.

b. Eyes sessile.

IV. Heteropoda. Foot compressed, fin-like, with a small sucker.

\section{Platypoda, Gray.}

Foot depressed, expanded: for crawling.

I. Podophthalma. Eyes on the top of cylindrical peduncles, separate from and at the outer side of the base of the elongate subulate tentacles.

\section{Fam. I. AMPULLARIADA.}

Rostrum produced, divided into two elongated subulate lobes. Tentacles filiform. Eyes peduncled. Gill one, rudimentary. Mantle with a large pulmonary sac on each side. Foot and opercular mantle simple. Operculum annular, regular. Mantle with a more or less elongate siphon in front. Male organ on the edge of the mantle.

Shell subglobose. Periostraca hard, polished, olive. Mouth entire. Peristome continuous.

Fluviatile. Oviparous. Eggs globular, deposited in masses on plants, \&c.

The length of the peduncle of the eye in Ampullaria varies in different species; in some it is well marked; in others the eye appears to be only placed on a small tubercle at the base of the tentacles.

The Ampullariae live chiefly in marshes which are subject to inundation; they are never found in rapid running streams. They are generally abundant, and cover a large space of country. They live 
a long time out of water when the marshes dry up. They afford nourishment to the marsh birds, especially the large Rails.

Siphon not produced. Operculum horny, with shelly internal coat. Peristome thickened.

\section{Pachystoma.}

Shell subglobose; spire short. Peristome continuous, thickened on the edge within; nucleus subcentral. Operculum horny, with a shelly internal coat.-Adams, Gen. Moll. t. 37. f. $1 a, b$.

1. P. fasciata, t. 47. f. 3 ; Adams, Gen. Moll.t. 37.f. 1.

2. P. Cebensis, t. 47. f. $1,2 \& 4$.

\section{Asolene.}

Shell subglobose; spire short; aperture oval; inner lip slightly thickened; outer thin? Operculum horny, with an internal shelly coat; nucleus lateral, anterior; siphon not exposed.

1. A. Platre, t. $47^{*}$. f. 4.

Asolene Platce is found in small marshes on the sands near the La Plata, at the roots of water plants; its movements are very slow, and it seldom comes out of its shell.

$\$ \$$ Siphon of mantle elongate, produced. Operculum horny, simple. Peristome thin.

\section{Marisa.}

Shell discoidal, largely umbilicated. Peristome simple. Operculum horny (Adams, Grn. Moll. t. 37. f. 3). Siphon elongate.

1. M. cornu-arietis. Ampullaria c., Lamk.; Adams, Gen. Moll. t. 37. f. 3 .

\section{Ampullaria.}

Shell subglobose, perforated; mouth large. Peristome simple, thin. Operculum horny, dextral (Adams, Gen. Moll. f. $2 a, b$ ) (fig. 35). Siphon elongate.

1. A. zonata, t. $47^{*}$. f. 2 .

2. A. Rossii, t. $47^{*}$. f. 1 .

Fig. 35.-Operculum of

3. A. scalaris, t. $47^{* *}$. f. 2 ; Adams, Gen. Moll. t. 37. f. 2 .

4. A. Ureus, Troschel, Wiegm. Arch. 1845, 197.

t. 8 (anat. f. 3 , teeth).

5. A. canaliculata, t. $47 * *$. f. 1 .

6. A. insularum, t. 117 . f. 1 .

7. A. - t. 117. f. 2.

Ampullaria.

Lingual membrane of Ampullaria — ? linear elongate. Teeth $3 \cdot 1 \cdot 3$; central broad, short ; apex slightly recurved, with a strong central tooth and a small toothlet on each side; inner lateral tooth 
broad, the inner part of the upper edge slightly reflexed, entire; outer lateral teeth subulate, curved.

Lingual membrane of Ampullaria from Pernambuco broad, brown.

Fig. 36.-Ampullaria canaliculata.

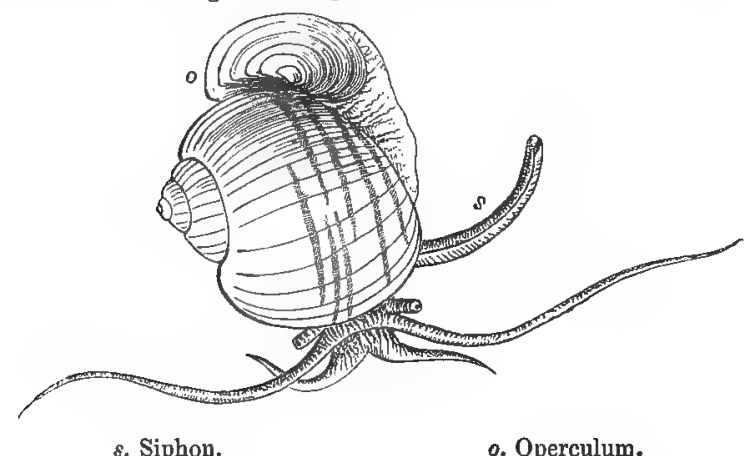

s. Siphon.

o. Operculum.

Teeth $3 \cdot 1 \cdot 3$; central broad, with seven teeth; the central larger, broad triangular or lance-shaped; lateral conical, smaller, outer smallest; inner lateral oblong trigonal, with a reflexed front edge, entire; two outer lateral compressed, subulate, curved, acute at the tip.

Fig. 37.-Teeth of Ampullaria.

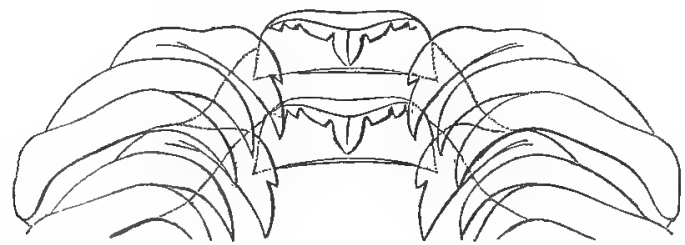

The animals of Ampullaria scalaris, A. canaliculata, and $A$. insularum have a very long exserted tapering siphon from the left side of the mantle, with a groove along its upper edge; $A$. Roissii and $A$. zonata a shorter truncated one, with a groove along its upper edge. Asolene Plate is without any appearance of this part. Their siphons differ from the siphon of the Zoophagous Mollusca in the edge being bent up and not down, leaving the groove along its upper and not its lower edge.

The gills of Ampullaria are formed of a series of triangular laminæ placed in a line down the right side of the branchial cavity, close by the side of the colon and ovarian tubes. A small mass of lamellæ on the outer left angle of the cavity; the rest of the cavity filled with a large fleshy bag open by a wide slit. Tentacles conical, elongate. Eyes on short tubercles, separate from but close to the outer base of the tentacles. Head short, the front of the side expanded into short, conical, tentacle-like lips. Foot simple, folded across 
when contracted. From the tentacles on each side to the base of the edge of the respiratory cavity is a continued broad flat plate, which is largest on the left side, and which appears to be bent up, so as to form a canal to conduct the water to the respiratory cavity. The one on the right side is folded, and gives origin to a fleshy ridge, which extends up the right side close to the side of the colon, and is continued to the top of the respiratory cavity. The penis is conical, elongate, near the tentacle, and enclosed in a bivalve sheath, with the thickened margin to the right side of the collar. They live a very long time out of water. Specimens have been brought alive from Egypt and India, kept dry in sawdust.

The Ampullarice appear to differ in size according to the soil on which they happen to live. In sandy places they are small and thin; where the soil is more muddy the specimens are larger.D'Orbigny.

The Ampullaria insularum of La Plata is found on the large aquatic plants in the marshes on the side of the river, especially such as have a muddy bottom. They lay their large red eggs in groups, in March. They live many months out of the water. They are eaten by the Rails and other water birds, who often break the operculum, the only vulnerable part, to get at the animal.

Ampullaria canaliculata is generally found on rushes and aquatic herbs; it also often glides on the surface of the water, shell downwards. The animal is generally expanded, but it contracts with the least touch. It walks slowly, its tentacles being in constant movement. In October its ovaries are filled with a mass of rose-coloured eggs; they are laid in November, on branches under water attached to a tree or bush out of the water. These eggs are a beautiful rose colour, with a whitish bloom. At the end of two or three days each group is closed; the eggs are then protected by a chalky pellicle, formed by exposure to the air. At the end of fifteen or twenty days, the young animals, which are of a pure rose colour, appear covering all the plants. If rain does not occur within this time, the eggs do not hatch, but the animals perish in the eggs from the drought. The young and old are eaten by the Wading birds, which often take the older ones to a branch of a tree and let them fall, so as to break the shell, and thus get at the animal; many shells so broken are to be seen at the roots of the trees.

\section{Pomella.}

Shell half-ovate, solid, striated, imperforate; mouth very large; inner lip concave. Peristome simple, thin. Operculum horny, dextral, on right margin (Adams, Gen. Moll. t. 37. f. $4 a, b$ ); inner lip coneave; shell striated.

\section{P. neritoides.}

The operculum of Pomella neritoides is thick, horny, as large as the mouth of the shell, with the nucleus on the middle of the inner straight edge. They are found at the mouth of the Rio Uruguay or Ampullaria River. They are most like a giant Neritina. 


\section{Lanistes.}

Shell sinistral, subdiscoidal, perforated; mouth ovate; lips simple. Operculum horny, sinistral, or with nucleus on left margin.-Adams, Gen. Moll.t. 37.f.5 $a, b$ (upside down). African.

1. L. Bolteniana.

2. L. ovum, Troschel, Naturg. 1845, t. 8.

The animal of Lanistes is very like the Ampullarice. The front of the head is bifid; the concave processes of the forehead and the tentacles are spirally twisted when contracted. There is a plate on each side of the body, forming a canal on the neck. The penis is contracted on the right side of the edge of the mantle. The air-bag is distinct. Operculum horny, with a subcentral nucleus. Teeth on lingual membrane $3 \cdot 1 \cdot 3$; the central and inner lateral curved, three-lobed; the two outer lateral subulate, hooked.-Erichson, Arch. 1845, t. 8. f. 6 .

\section{Meladomus.}

Shell ovate, simistral; spire conical; whorls convex; periostraca olive; mouth ovate; lips simple. Animal __ ? Operculum horny, sinistral ; nucleus subcentral, rather near the left margin.Adams, Gen. Moll. t. 37. f. $6 a, b$.

1. M. olivaceus.

II. Edriophthalma. Eyes sessile or nearly so, at the outer side of the base of the subulate tentacles.

A. Cryptocochlea, Gray. Mantle of adult animal expanded and often reflexed over the shell, which has a polished appearance.

\section{Fam. II. AMPHIPERASID $\approx$.}

Shell involute. Mouth linear; inner lip smooth. Lateral teeth on tongue-membrane; outer rugulose, broad, digitately lobed (fig. 38). Canal elongate, produced. Mantle lobes expanded, covering the sides of the shell, bearded externally.

The shell, when young, spirally striated; when adult, covered

Fig. 38.-Teeth of Amphiperas ovum.

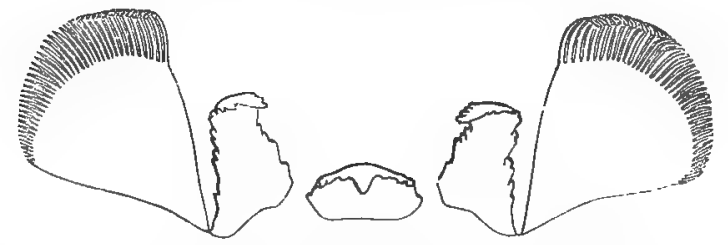

with a smooth enamel coat; the inner lip toothless, and the outer toothed or crenated; the anterior and posterior canal mostly elongated, straightish. 


\section{Amphiperas.}

Shell ovate, ventricose; the outer lip broad, inflexed, rounded, crenulated ; extremities short ; front of columella rounded ; mantleedge simple. Foot large, expanded.

1. A. ovum, t. 29 . f. 1,2 , t. 30.f. 3 , t. 105. f. 4 .

2. A. torile, t. 33. f. 3,5 .

3. A. dentatum, t. 86 a.f. 6 , t. 261 . f. 3 .

\section{Calporunus.}

Shell fusiform; outer lip inflexed, toothed; ends short, curved; hinder with a tooth on the inner side; front of columella expanded beneath.

$$
\text { * Outer lip broad. }
$$

1. C. verrucosus, t. 36 . f. 2 , t. 85 a. f. 5 .

** Outer lip inflexed, rounded, narrow, toothed.

2. C. adriaticus, t. 105. f. 7 .

*** Outer lip slightly inflexed, narrow, keeled externally, with edge shelving inwards.

3. C. pyriformis, Sow.

\section{Ultimus.}

Shell fusiform; outer lip thickened, inflexed, toothless ; extremities short ; front of the columella flattened; hinder part with a fold, obliterated by age. Rostrum moderate. Tentacles linear, subulate, elongate. Eyes subsessile, basal. Mantle lobes expanded over the shell, smooth externally. Siphon produced. Foot elongate, rather truncate in front, produced behind.

1. U. patula (Volva p.), Forbes \& Hanley, B.M. t. N.N. f. 1-4.

\section{Radius.}

Shell spindle-shaped; the outer lip thickened, slightly inflexed, toothless; the front of the columella rounded, the extremities more or less produced, elongate.

\section{* Extremities very long.}

1. R. volva, t. 86 a. f. 3 .

$$
\text { ** Extremities moderate. }
$$

2. R. spelta, t. 105. f. 6 .

The smaller Radii are found on Gorgoniz at the low-water mark of spring tides at Panama. The light-coloured specimens of Radius variabilis are found on cream-coloured Gorgoniæe, and the purple ones on Gorgoniæ of the same (purple) colour.-C. B. Adams, l. $c$. 256. 


\section{Fam. III. CYPR丑死.}

Shell ventricose, involute. Mouth linear; lips toothed. Canal recurved like a notch. Rostrum short. Tentacles elongate, subulate. Eyes external, basal. Mantle expanded on the sides. Gill with a siphon at each end, in a single series. Lateral teeth on tongue-membrane conical, curved. Shell of young smooth. Operculum none.

The individuals of the same species vary greatly in size, in the thickness of the base and margin, in the general form, and rarely in the size of the teeth; their most constant characters are the form of the front of the columella, the number of the teeth, and the general distribution of the colour. The great difference in size of the adults of the same species has been attempted to be explained by the theory that the animals shed their shells as the lobsters do their skin; but this is not the case; young shells may be found of all the various sizes. Individuals are to be found of most of the species which have had a coat of enamel (generally similar in colour to the margin) which has been deposited on their backs, after they have arrived at their full colour; sometimes this coat is blistery.

The young specimens, before the mouth of the shell is formed, have the mantle on the pillar side dilated and bearded, and of the outer side simple, with a slightly thickened edge. The foot is truncated. The tentacles subulate, far apart on each side of the trunk; eyes on small tubercles at the outside of the base of the tentacles. Foot simple, folded longitudinally when contracted; the lobes of the mantle often covered with tentacles.

The young shells (fig. 39) greatly resemble the shell of Bullina in general form, but they are distinguished from it by the inner lip not being thickened or elevated. The young shell of most of the species is smooth, but the young of Cyprcea pustulata is covered with regular, spiral, rather flat-tipped concentric ridges, with equal wide grooves between them; and the nucleus of $C y$ praa nigropunctata, which is only to be seen in the young shell, is finely, concentrically and spirally ridged, so as to be closely and acutely cancellated. The young shells under some particular circumstances have a ridge round the

Fig. 39.-Cypraa testudinaria. Young shell.

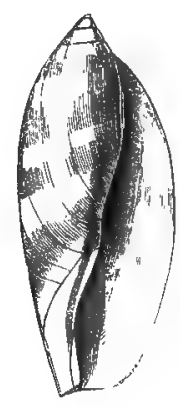
inner part of the outer lip, which is sharp, compressed, and strongly denticulated in front. These shells appear to have belonged to an animal which for some reason was prevented from forming a proper mouth to the shell.

The animal of $C$. arabica is black-brown, with a yellow edge to 
the foot; of $C$. carneola red, and white dotted; of $C$. felina pale, black dotted; of $C$. Talpa black, with small white specks; of $C$. caput serpentis brown, covered with red spotted tentacles.

\section{* Inner lip with a well-defined ridge in front.}

1. Cyprea.

Shell ovate, polished; spire bidden; lip toothed; anterior and posterior canal distinct, recurved; front of pillar lip smooth, broad, deeply impressed, edged with a single large oblique fold in front, separated from the teeth by a deep groove.

Fig. 40.-Teeth of Cyprea helvola.

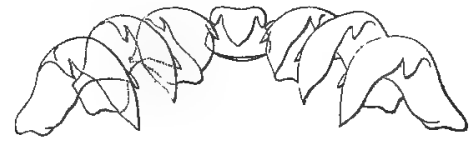

Central tooth of Cyprea helvola small, wider at the base; cutting edge with a large lobe in the middle, and a smaller one on each side; lateral teeth somewhat similar; first smaller, with long hooks; a tooth on the outside at the bend, and a small tooth on the inside near the end (fig. 40).-Loven.

a. Shell smooth; columellar pit transversely ridged; teeth of inner. lip generally long.

1. C. stercoraria, t. 34 . f. 8 , t. 35 . f. 4 .

2. C. Tigris, t. 30 . f. 1,2 , t. 32 . f. 1 ㅇ, t. 35. f. 6 ð .

3. C. Tigrina, t. 31 . f. 3 , t. 35 . f. 5 .

4. C. mauritiana, t. 31 .f. 1, t. 35. f. 2, t. 36. f. 5, young.

5. C. arabica, t. 33 . f. 6, t. 34 . f. 1, t. $83 \alpha$. f. 5 .

6. C. vitellus, t. 34 . f. 5 .

b. Shell smooth; columellar pit (nearly) smooth; teeth of inner lip short or indistinet.

7. C. Talpa, t. 31. f. $2=$ Adams, Gen. Moll. t. 28 . f. I.

8. C. Isabella, t. 36 . f. 3.

c. Shell : back warty (rarely smooth), base ridged.

9. C. nucleus, t. 34. f. 4 .

\section{d. Shell with transverse ribs.}

10. C. Childreni.

e. Shell with longitudinal and transverse ribs.

11. C. Adamsonii. 


\section{Aricia.}

Shell ovate, smooth, polished; spire hidden; lips toothed; canal recurved; front of pillar flat, or nearly so, and cross-ridged, with a distinct fold in front, separated from the teeth by a deep groove.

a. Margin of the shell pitted on the upper edge.

1. A. erosa, Fig. Moll.t. 33. f. 1, 2 ; Adams, Gen.Moll.t. 261.f. 2.

b. Margin entive; teeth of both lips extended more or less over the

2. A. annulus, t. 34 . f. 6 .

3. A. Moneta, t. 34. f. 9.

4. A. caput serpentis, t. 33. f. 4 .

5. A. Caurica, t. 261 . f. 1 .

6. A. variolaria, t. 34 . f. 3 .

7. A. rufa, t. 35 . f. 1-3.

8. A. cribraria, t. $34 . \mathrm{f}, 2$.

c. Margin entire; teeth of inner lip very small, forming a slight ridge; front of columellar lip slightly concave, produced, and toothed internally.

9. A. angustata.

\section{Naria.}

Shell ovate, polished; spire hidden; lips toothed; front of the columella narrow, dilated into a sharp-toothed ridge, with a distinct fold in front, separated from the teeth by a deep groove.

1. N. irrorata.

** Inner lip without a distinct fold in front.

4. Trivia.

Shell subglobose, cross-ribbed; aperture toothed; front of the pillar internally concave, ribbed, without any distinct fold in front. Rostrum short. Tentacles elongate, linear. Eyes basal, sessile. Mantle produced, nearly covering the shell, smooth externally. Foot elongate, truncated in front, elongated and much produced behind the shell. Siphon elongate, produced in front.

a. Mouth wide; outer lip slightly inflexed; shell equally ribbed.

1. T. australis, t. 34. f. 7 .

b. Mouth narrowish; outer lip wide; ribs of back subequal, linear.

2. T. europær, t. 36. f. 1 ; Sars, t. 36. f. 6 ; Forbes \& Hanley, B. M. t. N.N. f. 5, 7, cop. Arlums, Gen. Moll. t. 28. f. 5. 
c. Mouth narrowish; the outer lip arched; the ribs enlarged or 3. T. pulex. tubercular near the dorsal groove.

d. Mouth narrow; ribs tubercular; dorsal line distinct; front of 4. T. pustulata. columella smooth.

The branchial plume of Trivia europaea is a large, finely pectinated, half-moon-shaped Fig. 41.-Trivia europrea. plate of two segments, each appearing to have a branchial artery. The male organ is large, spatulate, folded.

Mr. Clark (Mollusca, 505) describes Trivia europcea "as having a long proboscis, which can be exserted, though it is rarely seen," and which has not been observed in the larger Cowries (Cypraa). Dr. Lovèn, who specially examined the mouth of $C$. helvola and $C$. europcea, describes the rostrum as short, prominent, and not retractile.

Central tooth of Trivia europaea longer than broad, cutting edge subtriangular, denticulate on each side, with a sharp lobe in the middle; lateral teeth dissimilar; the first at the tip with a long point, denticulate on each side; second and third simple, claw-like.-Lovèn (see fig. 41).

\section{LUPONIA.}

Shell pear-shaped, smooth, or cross-ribbed; mouth linear ; front end of the columellar lip crossed by several irregular ridges, without any distinct marginal one, internally narrow, flat.

1. J. Algoensis.

\section{Cypreovula.}

Shell pear-shaped, smooth, or cross-ribbed; mouth linear; spire hidden; front end of columella covered with regular cross ribs, like rest of base, internally produced into an acute-toothed ridge.

1. C. Capensis.

$$
\text { * Shell finely cross-ribbed. }
$$

2. C. umbilicata, Sow.

$$
\text { ** Shell smooth. }
$$

\section{Erato.}

Spire conical; apex submamillary, blunt; shell, when young, smooth; the adult with both lips finely crenulated; the columella concave, slightly radiately plaited or smooth, with two or three folds 
in front ; the anterior canal straight, the hinder indistinct. Rostrum moderate, annulate. Tentacles linear, elongate. Eyes sessile, basal. Mantle reflected over the shell, rugulose externally. Foot elongate, truncated and expanded in front, produced behind. Siphon elongate, produced in front.

This genus differs from Marginella in having a rostrum or proboscis, as shown by the figure cited.

\section{a. Shell smooth.}

1. E. Cypreola? t. 102 . f. 7.

2. E. lævis (Marginella 1.), Forbes \& Hanley, B. M. t. N.N. f. 8, 9, cop. Adams, Gen. Moll. t. 20. f. 1.

\section{b. Shell tubercular.}

3. E. scabriuscula.

Mr. Clark describes Erato Cypreola as having a retractile proboscis ! but the description is avowedly only compiled from Philippi, aided by memory !-See Mollusca, 506.

\section{Fam. IV. PEDICULARIADA.}

Rostrum wrinkled. Mantle enclosed, thickened on the edge, not produced into a siphon in front. Eyes sessile, lateral, basal. Foot small. Teeth $3 \cdot 1 \cdot 3$; lateral very long, deeply lobed. Operculum none. Shell irregular, ovate, subconvolute, covered with a radiately ridged callous coat; spire lateral, minute. Mouth very wide; outer lip sinuous ; inner lip callous, rounded, and covering part of the last whorl. Shell of young animal regular.-Ann. \& Mag. N. H. 1846, xviii. 428.

Parasitic on coral, forming a hole in its surface.

\section{Pedicularia.}

1. P. Sicula.

2. P. fimbriata, A. Adams.

Central tooth of Pedicularia Sicula depressed, subquadrate, cutting Fig. 42.-Teeth of Pedicularia Sicula.

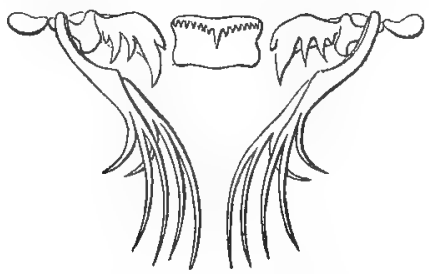

edge transverse, with one sharp point and denticulated; lateral teeth 
dissimilar ; first transverse, with four unequal sharp points; second and third bent back, similar, slender, elongated, slightly sigmoid, the tip cleft into three spines, the outer short, the inner longest; the limb with a transverse plate, which is curved and ovate (fig. 42).

The shell of Pedicularia has much the appearance of Concholepas, for it only differs from that genus in having no tooth-like process on the front of the outer lip, and in the edge of the outer lip being generally sinuous, and the inner or columellar lip being rounded, callous, and covering part of the left side of the last whorl. There is a small white shell in Mr. Cuming's Collection from the Philippines, which has similar characters, and is even more like the typical Concholepas.

Mr. A. Adams has thus described the shell, which he referred to a genus under the name of Coralliobia: "Like Concholepas, but no teeth on front of outer lip."-Ann. \& Mag. N. H. 1854, 70.

The form and disposition of the teeth at once separate the animal from Concholepas and the other Purpuridee.

Dr. Lovèn described the teeth of Pedicularia directly after Calyptraadce, and Dr. Philippi arranges it as the last genus of Calyptrceacea.-Handb. der Conch. 189.

\section{Fam. V. APORRHAID压.}

Outer edge of the mantle expanded, lobed or reflexed on the edge of the shell. Shell spiral when adult; outer lip expanded or revolute. Operculum annular.

\section{Aporrhais.}

Shell fusiform; aperture narrow; canal distinct; outer lip dilated, lobed. Operculum ovate.

1. A. pes-pelecani, t. 91.f. 1-4; Forbes $\&$ Hanley, B.M.t. F.F.f.3; ddams, Gen. Moll. t. 27. f. 5.

Central tooth of Aporrhais pes-pelecani narrow, above wider, convex ; cutting edge wide, with a central spine, denticulated on each side ; first lateral tooth almost transverse, upper margin folded,

Fig. 43.-Teeth of Aporrhais pes-pelecani.

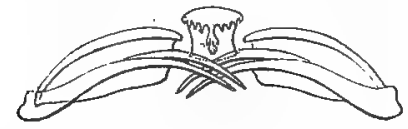

unarmed; second and third similar, claw-like, slender, elongated, simple, decussated with the opposite (fig. 43).

The Aporrhais pes-pelecani creeps slowly; but the organs do not appear adapted for progressive movement. It is shy, and whether 
the shell is placed with the aperture upwards or downwards, it does not usually commence creeping by pushing out the foot anteriorly,

Fig. 44.--Aporrhais pes-pelecani.

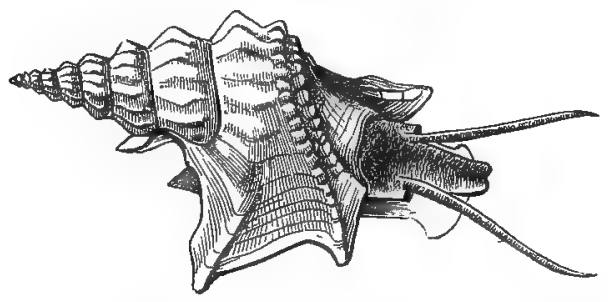

like other Gasteropods, but often twists the long neck and foot to the caudal extremity, and there fixing it, with a sudden spring effects the turning of the shell.-Clark, Moll. 474.

Branchial plume single, long, narrow, with about forty very short pectinations; above the plume there is a glandular substance resembling the mucous fillets of the Canalifera.-Clark, Moll. 472.

The shells of Aporrhais are subject to great variety with respect to the outer lip, which increases by age. Young shells have all the appearance of a Murex, without the least expansion of the lip, and all gradations are to be met with from that to the perfect shell.

The animal of the $A$.pes-pelecani has a long snout and two filiform tentacula of a pink colour, the former spotted with white. Eyes black, at the base of the tentacula beneath; sustentaculum short, white.

\section{Struthiolaria.}

Shell ovate; spire conic ; mouth ovate; canal short, indistinct; lips thickened, reflexed and rounded on the edge. Operculum ovate, acute.

a. Operculum ovate, acute, with a notch below the tip (fig. 45). 1. S. papillaris.

\section{Operculum: apex very acute, without any distinct notch.}

2. S. crenata.

Rostrum of Struthiolaria crenata elongateconic when alive, when contracted in spirits short, thick, annulated. Tentacles subulate, lateral; eyes small, on outer side of the base. Lingual membrane thin; teeth $3 \cdot 1 \cdot 3$; central subovate; apex truncated, reflexed, entire; lateral slender, subulate, curved; apex acute, entire, inner largest. Foot small, oblong. Operculum small, ovate; apex very acute, solid, transparent, with a broad notch or rather sinuation on the

Fig. 45. Operculim of Stru. thiolaria papillaris. inner side near the tip.

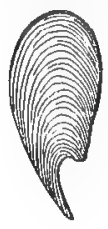




\section{Pelicaria.}

Shell spiral ; spire of adult covered with an enamel coat ; aperture ovate; outer lip sinuous, sharp-edged. Operculum like Struthiolaria?

1. P. vernis, t. 5.f. 3.t. 91.f. 6 ; Adams, Gen. Moll. t. 27. f. 6.

\section{Trichotropis.}

Shell top-shaped; whorls keeled, edged with a horny fringe; mouth ovate, angulated in front; outer lip simple, acute, angulated. Opereulum horny, ovate; apex sometimes curved; nucleus apical, small.-Adams, Gen. Moll. f. $6 a, b$.

\section{a. Spire conic; whorls contiguous.}

1. T. bicarinata, Sowerby, t. 24. f. 7 .

Operculum of Trichotropis bicarinata ovate; nucleus oblong, on the outer side of the front edge. Mantle enclosed, with two slight canals on the middle of the outer edge. Siphon not distinct, very small, smaller than the canal on outer lips. Foot oblong, rather truncated and double-edged in front. Tentacles subulate, blunt, lateral. Eyes sessile, rather above the outer hinder part of their base. Male organ small, behind base of right tentacle. Rostrum broad, short, annular, with a terminal perpendicular mouth. Lingual membrane short, broad, with broad lateral expansions. Teeth $3 \cdot 1 \cdot 3$; central three-toothed, acute, denticulated (?) ; inner lateral recurved at the tip, entire ; outer subulate, arched, simple.

These teeth differ considerably from those of Tropiphora borealis figured by Lovèn; and that author described the animal as having a long retractile proboscis, with the tentacles united by a membrane, which is certainly not the case in this species.

b. Spire very short; whorls subseparate. Separatista.

2. T. Blainvilliana, Petit, Journ. Conch. ii. 1852, t. 1. f. 5.

\section{Calcarella.}

Shell like a small Trichotropis bicarinata, but very thin, and the outer lip angularly produced.

1. C. spinosa, Soul. Journ. Conch. 1850, i. 217. t.

\section{Sinusigera.}

Shell turbinate, ovate, dextral, imperforate; whorls keeled; nucleus sinistral; aperture ovate, corniculate in front; outer lip with two claw-like lobes; the middle one a prolongation of the keel, the other nearer the canal; lips thickened, reflexed. Operculum thin.

Gregarious ; floating on the sea. 


\section{a. Cancellated.}

1. S. cancellata, $d$ Orb., in Sagra, Cuba, 1846, t. 23. f. 7, 9 .

\section{b. Smooth.}

2. S. microscopica, (Struthiolaria m.) Gray, Beechey's Foy. $_{\text {. }}$

The foot of Sinusigera Huxleyi is destitute of a float, with a very thin, small operculum. Mantle with a short respiratory siphon. The branchiæe are of two kinds, covered and naked; the covered gill is single, but of considerable length, beautifully pectinated and fringed with long cilia. The naked gills are four in number, similar in character to those of Macgillivrayia. Each gill is oval or elongated, with a thin, frilled and corrugated border, beset with long whip-like cilia. The lingual strap with central and lateral teeth, and two file-like triturating plates. Tentacles two on each side.-Macdonald, Proc. Roy. Soc. vii. 193, 1854.

Sinusigera was arranged by d'Orbigny (Moll. Cuba, 149) near Nassa, on account of its thickened outer lip. It is distinguished from the other Buccinida by the ringent mouth and three well-marked sinuses separated by prominent lobes. It was first described as a Struthiolaria by me from a specimen in the Paris Museum.

B. Cochlea. Mantle enclosed in the shell (p. 68).

a. Phaneropneumona. Gills vascular, branched, on the inner surface of the mantle. Terrestrial.

These differ from Pulmonata in the mantle being free from the nape, leaving the pulmonary cavity open. Animal unisexual. Operculum distinct, spiral, or annulated.

\section{Fam, VI. CYCLOPHORIDÆ.}

Gills vascular, branched. Shell free, conic. Mouth roundish or

Fig. 46.-Teeth of Cyclophorus Tuba.

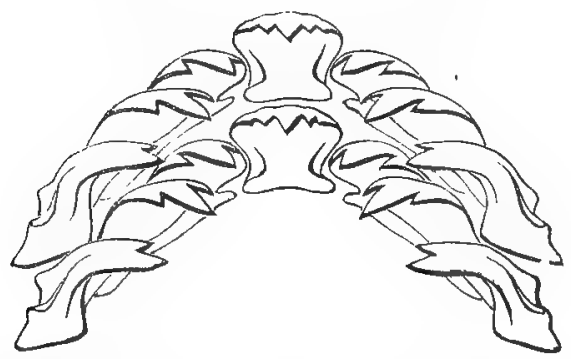

ovate. Eyes sessile, on the outer side of the base of the tentacles. Operculum spiral.

Terrestrial. 
Rossmäsler has examined the teeth of Cyclostomus elegans, $C$. sulcatus, C. (Leonia) ferrugineus, and C. (Tudora) mamillaris.Icon. iii. 28.

A. Operculum orbicular, often concave externally, of many very gradually enlarging whorls; nucleus central.

a. Cyclotina. Operculum thick, formed of two lamince, with a groove on the edge between them, the interior horny, the outer layer calcareous; the whorls usually furnished with a raised border on the outer edge, forming a spiral ridge or fringe.

\section{Cyclotus.}

Operculum thick, testaceous, outer surface rather concave; whorls numerous, very gradually enlarging, furnished with a thickened or raised border on the outer edge. Shell subturbinate, depressed or discoidal. Peristome continuous or joined by a callous margin, simple or double, straight or reflexed.

1. C. Inca, t. 311 .

2. C. ? trochiformis, t. 303. f. 11 .

3. C.? anguliferus, t. 303 . f. 9 .

4. C.? maculatus, t. 303 . f. 7 .

\section{Pterocyclos.}

Operculum subcartilaginous, many-whorled, spirally lamellated, concave inside. Shell broadly umbilicated, rather discoidal. Peristome generally double; the internal short, cut on the right margin; the external dilated above into a roof-shaped beak.

1. P. rupestris.

\section{Opisthoporus.}

Operculum calcareous, thick, many-whorled, formed of two laminæ with an intermediate hollow space and a groove round the exterior margin. Shell depressed, orbicular, broadly umbilicated; last whorl with a small, sutural, exserted tube behind the aperture. Peristome double, expanded.

1. 0 . biciliatus.

2. O. tubuliferus.

\section{Craspedopoma.}

Operculum horny, solid; whorls very narrow, with a central nucleus; external plate flat; internal deeply concave, furnished with a circular prominence on the penult whorl. Shell subturbinate, gaping; last whorl a little constricted anteriorly. Peristome continuous, simple, receiving the internal prominence of the operculum.

1. C. lucidum. 
b. Operculum horny, thin, without any external calcareous layer. Shell conical, depressed; last whorl rounded, without any groove or ridge round the front of the axis.

\section{Aulopoma.}

Operculum horny, with many whorls, Planorbis-shaped, composed of two plaits, between which it has a spiral channel, which is interiorly open on the last whorl. Shell turbinate-depressed, or discoidal ; the last whorl disjoined anteriorly. Peristome free, straight, continuous, immersed in the circular groove of the operculum.

1. A. helicinum.

\section{Cyclophorus.}

Operculum horny, thin, closely whorled, more or less concave externally. Shell globose-turbinate, depressed or discoidal. Peristome continuous, expanded or straight.

1. C. volvulus.

\section{Leptopoma.}

Operculum membranous, closely whorled, flat. Shell globose-turbinate or conical, narrowly umbilicated. Peristome simple (rarely double), reflexed (rarely straight), with distant margins, joined sometimes by a very thin callus.

1. L. multilabris, t. 311 . f. 8 .

\section{Alycaus.}

Operculum orbicular, rather shelly, obsoletely many-whorled. Shell conical or depressed; spire regular; last whorl distorted, compressed, much contracted behind the aperture; mouth circular. Peristome regularly reflected.

1. A. gibbus.

\section{Diplommatina.}

Operculum shelly, thin, orbicular; whorls few, with thin prominent lamellæ on their external edges. Shell scarcely rimate, thin, subovate; whorls convex, last subascendent; aperture nearly circular. Peristome interrupted, expanded.

1. D. folliculus.

Mr. Benson denies that this genus has an operculum, and thinks those described are adventitious; they were attached to the animal dried in the shell, and have been observed in two species. He also describes "the eyes on the posterior part of the tentacles at their base." Hence Mr. Adams has proposed it should be arranged with the Truncatellida. 
c. Pupinina. Operculum horny, thin, many-whorled, without any external calcareous layer. Shell oblong, elongate; last whorl with a fold or spiral ridge on the inner side in front of the axis, sometimes forming a groove in the inner lip.

\section{Megalomastoma.}

Operculum orbicular, thin, horny, many-whorled, rather flat Shell narrowly or scarcely perforate, oblong, turrited or Pupashaped; aperture rather circular, sometimes furnished with a slight lateral channel. Peristome double or simple, rather thickened, rarely straight.

1. M. brunnea, t. 311. f. 15 .

\section{Cataulus.}

Operculum orbicular, flat, horny, many-whorled, separable into many plates, forming a continuous spiral lamina like a corkscrew. Shell perforate, Pupa-shaped, not callous, furnished with a filiform basal keel; aperture entire, prolonged at its base by a rather circular channel. Peristome continuous, dilated at its lower extremity into the keel of the last whorl.

1. C. tortuosus.

\section{Pupinella.}

Operculum horny, many-whorled. Shell oval, covered with a thin horny periostraca ; aperture circular. Peristome reflexed, thickened, with a groove on the inner side of front near the axis.

1. P. pupiformis.

\section{Pupina.}

Operculum thin, membranous, narrow-whorled, rather flat. Shell Pupa-shaped, for the most part covered by a smooth callus. Peristome simple, thickened or reflected; columellar margin divided in the middle by a transverse channel; right margin forming a second channel at its insertion.

1. P. humilis.

\section{Registoma.}

Operculum orbicular, thin, horny, many-whorled. Shell ovate. polished, callous; aperture circular, rather entire. Peristome reflected; inner lip thin, simple; columellar margin slightly curved and channeled in the middle.

1. R. grandis.

\section{Callia.}

Operculum thin, membranous, narrow-whorled. Shell pupiform, covered with a smooth shining callus. Peristome subcontinuous, straight, scarcely thickened; columellar margin entire, above appressed-reflexed, altogether closing the perforation, which is conspicuous in young shells.

1. C. lubrica. 
B. Licinina. Operculum nearly orbicular, composed of a few gradually-increasing whorls; nucleus somewhat excentrical.

a. Operculum thick, testaceous.

\section{Jamaicia.}

Operculum shelly, externally convex, composed of a small number of obliquely-striate, rather coarse, sublamellar whorls. Shell umbilicate, globose-conical; aperture circular. Peristome simple or double, straight or reflected.

1. J. anomala.

\section{LrCrna.}

Operculum —_ ? Shell conical; last whorl usually produced out of the spiral line, straight: mouth circular. Peristome somewhat reflexed, expanded.

1. L. labia.

\section{Choanopoma.}

Operculum calcareous, nearly circular, with gradually-enlarging whorls, terminating externally in more or less prominent, thin lamellæ, with a subexcentrical nucleus. Shell globose-turbinate or turrited, often truncate; aperture rather oval or roundish. Peristome usually double, with the outer edge angularly expanded.

1. C. pulchra.

\section{b. Operculum thin, cartilaginous.}

\section{Adamsiella.}

Operculum orbicular, thin, rather cartilaginous; whorls few, enlarging gradually, with the outer edge rather detached; nucleus subcentral. Shell Pupa-shaped or oblong-turrited; aperture small, rather circular. Peristome for the most part double, more or less expanded or reflexed.

]. A. mirabilis.

C. Cyclostomina. Operculum ovate, composed of few whorls, more or less rapidly enlarging, with the nucleus excentrical.

a. Operculum thick, with an external shelly coat.

20. Lithidion.

"Operculum subcircular, shelly; whorls rather rapidly enlarged, with a strong, convex, subcentral keel and simple edges. Shell depressed, broadly umbilicated, open; aperture rather circular. Peristome simple, often thickened.

1. L. sulcatum. 


\section{1. Ототома.}

Operculum shelly, solid; whorls convex in the centre, with simple edges. Shell conically subglobose or depressed; aperture subovate. Peristome straight or slightly expanded, with the columellar margin for the most part dilated, covering part of the axis, or closing the umbilicus.

1. O. Listeri, t. 31 i. f. 10 .

\section{Cyclostomus.}

Operculum rather ovate, shelly, flat; whorls four to five, gradually increasing, with simple margins; nucleus excentric. Shell depressed, globose-turbinate or ovate-turrited; aperture ovate. Peristome simple, straight or expanded, often double.

1. C. elegans, t. 293. f. 1 , t. 311 . f. 5 ?, 9 ?, 14, 16, 17.

2. C. novæ hiberniæ, t. 311 . f. 13 .

Fig. 47.-Cyclastomus elegans.
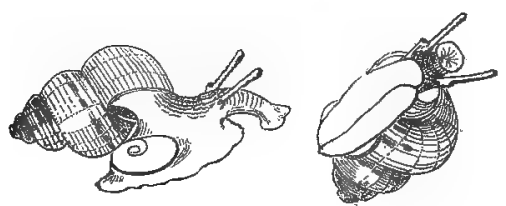

23. Tudora.

Operculum ovate, shelly, flat, of few whorls, which are enlarged rapidly and arcuately grooved or deeply striated obliquely, with the nucleus very excentrical. Shell ovate-oblong or turrited; aperture angularly ovate. Peristome expanded, simple or double.

1. T. ferruginea.

\section{LeONia.}

Operculum ovate, shelly, very convex externally, with a single whorl and the nucleus situated near the columellar margin. Shell ovate-conical; aperture ovate. Peristome simple, slightly reflexed.

1. L. mamillaris.

\section{Cistula.}

Operculum ovate, thin, cartilaginous, with a thin external shelly coat with few gradually increasing whorls, the margin of which is usually detached; nucleus excentrical. Shell globose-conic or ovate, or oblong-turrited, usually truncate; aperture ovate. Peristome simple, expanded or double.

1. C. catenata.

b. Operculum thin, horny; last whorl rounded in front.

\section{Chondropoma.}

Operculum ovate, subcartilaginous, flat; whorls few, rapidly in-

$$
\text { G } 2
$$


creasing, with the nucleus very excentric. Shell oblong-turrited, often truncated, sometimes globose-turbinated; aperture ovate. Peristome simple or more or less distinctly doubled, nearly straight, expanded or broadly reflexed.

1. C. pictum,

c. Pomatianina. Operculum thick, of two horny coats, concamerated within.

27. Pomatias.

Operculum cartilaginous, few-whorled, composed of two plates, concamerated within. Shell somewhat imperforate, conico-turrited or turrited, longitudinally striated or ribbed. Peristome nearly simple or double, the internal edge continuous, the external expanded or reflexed, often auriculated.

1. P. maculata, t. 311 . f. 19 .

d. Realiana. Operculum thin, horny; front of last whorl with a keel round the axis, and sometimes a notch in the front of the lip, like Pupiniana, but the operculum is ovate, few-whorled.

28. Liarea.

Operculum thin, few-whorled, horny. Shell turrited, rather smooth; aperture ovate. Peristome continuous, double.

1. L. Egea.

\section{Realia.}

Operculum thin, few-whorled, horny. Shell perforate or narrowly umbilicate, turrited, or globose-turbinate, keeled round the perforation; aperture ovate. Peristome straight or expanded, with distant margins.

1. R. rubens, t. 311 . f. 11 .

2. R. erosa, t. $311, f, 12$.

\section{Bourciera.}

Operculum ovate, rather solid, horny, of a few rapidly-increasing whorls. Shell Helicina-shaped; columella toothed beneath; aperture ovate. Peristome spreading.

1. B. helicinæformis.

\section{Fam. VII. OLIGYRADA.}

Eyes on outer side of the base of the tentacles. Gills vascular, free. Shell conical or subglobose ; aperture half-ovate. Operculum annular, not spiral, shelly, thick, or horny and thin, semi-ovate or rather triangular; nucleus subcentral, lateral.

Terrestrial.

The animal absorbs the septa between the upper whorls, as in Auriculida, Helicinida, Proserpina, Neritina, \&c. 


\section{Stoastoma.}

Operculum anuular, calcareous, externally very deeply concave, with lamellæ slightly and irregularly projecting from the surface. Shell globose-conic, depressed or discoidal; aperture semioval or nearly semicircular, angulated above and beneath. Peristome continuous, with the right margin arcuate, left margin nearly straight, sending off at its base a more or less distinct keel, which surrounds the more or less open perforation.

1. S. succineum.

$$
\text { * Shell smooth. Electrina. }
$$

2. S. pisum.

$$
\text { ** Shell spirally costate. }
$$

\section{Trochatella.}

Operculum annular, semioval, flat, pale, more or less solid. Shell top-shaped, or globose-conic; aperture semioval, rather triangular ; columella nearly flat, not sending backward any basal callus, sometimes uniting the margins of the peristome by a very thin deposit, which is not diffused.

1. T. pulchella.

\section{LUCIDELLA.}

Operculum membranaceous, semiovate, with the columellar margin scarcely thickened. Shell depressed, heliciform, not callous beneath ; aperture sinuate, rather triangular. Peristome thick, furnished with stout teeth.

1. L. aureola.

\section{Helí̉ina.}

Operculum semiovate, membranaceous or shelly. Shell heliciform, turbinate, globose or depressed, covered beneath with callus round the columella, which is rather straight and somewhat flattened; aperture triangular or semiovate, entire. Peristome simple, straight or thickened, often spreading broadly.

a. Shell smooth. Peristome more or less toothed internally.

1. H. depressa.

\section{b. Shell smooth. Peristome not toothed.}

2. H. neritella.

3. H. flammea, t. 311 . f. 3.

4. H. tæniata, t. 311 . f. 1 .

5. H. Sandwichensis, t. 303 . f. 10 .

6. H. oresignæ, t. 31 l. f. 6 .

7. H. zephirina, t. 311 . f. 2 .

8. H. variabilis, t. 290 . f. 9 , t. 311 . f. 7 .

9. H. occidentalis, t. 311 , f. 4 .

'Tongue-membrane of Helicina agglutinans rather broad, thin. 
Teeth large, brown, $3 \cdot 1 \cdot 3$; outer lateral slender, linear, thin, nearly straight, curved at the tip.

c. Shell with very close long spiral epidermal fringes. Schasicheila, Shutt.

10. H. alata.

\section{Alcadia.}

Operculum annular, rather solid, semiovate, furnished at its lower extremity with a tooth-like appendage. Shell heliciform, turbinate, subglobose or slightly depressed, for the most part hairy, covered with callus round the columella, which is flattened, nearly rectilinear. Periostraca often covered with lines of hairs. Aperture semiovate, rather triangular. Peristome more or less expanded, separated from the columella by a distinct, for the most part curved, slit.

1. A. major.

Fam. VIII. PROSERPINIDAE.

"Tentacles two, subulate. Eyes subsessile, on the outer side of their base." - Shuttleworth, 1854. Mantle more or less expanded over the shell? Shell spiral, depressed, polished; whorls rounded; spire Iow. Mouth lunate, cavity with spiral laminæ on the inner and outer lip. Peristome acute; axis covered with a callous deposit. Operculum none.-Bland.

Terrestrial. Mexico; Jamaica and Cuba.

The arimal, as in Stoastoma, Helicina, Neritina, Auricula, and some Helicida, absorbs the septa between the upper whorls of the spire.-Bland.

\section{Proserpina.}

Character of Family.

1. P. nitida.

b. Pseudopneumona. Gills in very numerous cross folds on the inner surface of the mantle. Eyes on the front side of the base of the tentacles. Operculum spiral (p. 78).

\section{Fam. IX. LITTORINID A.}

Shell spiral, free. Mouth of the shell entire. Mantle edgt simple. Foot moderate : for walking. Trunk produced, wrinkled not retractile. Jaws horny, distinct. Tentacula far apart on side of head. Gills : one, very large, occupying nearly the whole surfact of the cavity, and formed of numerous flat free plates. Teeth few central 1 ; lateral $3 \cdot 3$, converging. The opercular lobe is simple. not appendaged behind.

Marine. Amphibious. 


\section{a. Tentacles simple.}

* Eyes on elongated pedicels, united to the short tentacles. Operculum ovate, of few whorls.

\section{Assiminea.}

Eres on pedicels, united to the short tentacles.

1. A. Gravi, t. 51 . f. 8, t. 123. f. 6; Forbes \& Hanley, B. $\boldsymbol{M}$. t. H.H. f. 6 .

Central tooth of Assiminea Grayana (fig. 48) wider below the base, truncated in the middle, prominent on both sides, produced

Fig. 48.-Teeth of Assiminea Grayana.

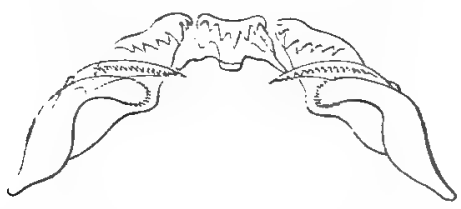

into a horn; cutting edge triangular, with from five to seven pointed lobes; first lateral tooth with seven teeth, the third tooth larger; second slender; scape narrow, claw-like, serrated on the outside; the third rounded at the tip, ciliato-denticulate.-Lovèn.

When the animal was first described in $1 \$ 21$, I observed that it differed from all others of the Order in the eres appearing to be placed at the end of the tentacles, but I believed they were placed on peduncles as long as the tentacles, the two being soldered together; for if the pedicels of the eres of this genus are minutely examined, they seem to be formed of two parts united by a suture; and Mr. Berkeler observes, that it would appear as if there were in reality no tentacula, but only the tubercles common to many mollusks at the base of the tentacles, a little more developed than usual.

The genus Assiminea is an instance of shells ver nearly allied in external appearance having very different animals. "The shell is not to be distinguished from the smaller Littorina.

** Eyes nearly sessile, on outer side near the base of the tentacles.

+ Operculum ovate, of few whorls.

\section{LitTorina.}

Eyes sessile, on base of tentacles. Shell ovate, solid, imperforated; spire short; aperture ovate; inner lip concave, outer simple. Littoreal.

1. L. littores t. 5l. f. 4 ; Forbes \&-Hanley, B. M. t. G.G. f. 3 ; Adans, Gen. Moll. t. 33. f. 1.

2. L. varia, t. 127 a. f. 2. 
3. L. canariensis, t. 125. f. 10.

4. L. serialis, t. 127 a. f. 3 .

5. L. patula, Forbes \& Hanley, B. M. t. G.G. f. 2.

6. L. Gaudichaudi, t. 127 a. f. 1 .

7. L. peruviana, t. 123 . f. 4.

8. L. Araucana, t. 123. f. 1.

9. L. flava, t. 123. f. 2.

10. L. diemensis, t. 51 . f. 3.

11. L. luteola, t. 51. f. 2.

12. L. scabra, t. 51 . f. 1 .

13. L. pyramidalis, t. 51. f. 6.

14. L. miliaris, t. 123. f. 5.

15. L. punctata, t. 51. f. 5, with a produced siphon? like a Buccinum!

The tentacles subulate, rather distant. The eyes rather prominent, on the outer base of the tentacles. Operculum horny, ovate, spiral, of a few very rapidly enlarging whorls. They inhabit the sea-coast between high and low water mark, where they are often left dry for many hours by the tide; and sometimes they crawl so bigh up the rock as only to be wetted by the spray. The pectinations of the branchial plume of nearly all the Littorince vary from forty-five to sixty; thin, long, slender, and close-set.

The branchial plume of Littorina littoralis is single, on the left side, with thirty-five to forty or more very fine, close-set pectinations; the neck is simple, without lobes.-Clark, 347.

The anterior folded jaws of $L$. littoralis are supported by the usual corneous plates.-Clark, 347.

The buccal mass of $L$. neritoides is supported by two thin, brown, corneous plates, from whence a very long, white, spiny tongue proceeds to the stomach, and there lies coiled as in L. littorea.-Clark.

Central tooth of Littorina littorea (fig. 49) subquadrate, convex above; cutting edge narrow, cordate-lobed in the middle, on both

Fig. 49.-Teeth of Littorina littorea.

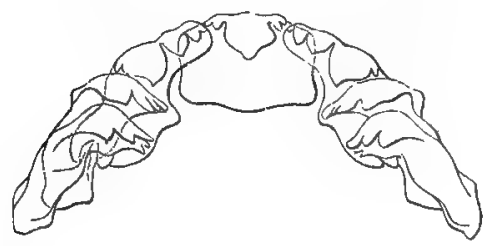

sides obtusely denticulate. Lateral teeth somewhat similar, thick, the tip unequally dentate-lobed, the first on the outside curved and prodisced.

In walking, Littorina littorea alternately advances first one and then the other side of the foot. 
Littorina littorea, L. retusa, L. petraa, and several others, are oviparous; the egg-masses of $L$. retusa are oval, almost three lines broad. Some species, as $L$.rudis and $L$.rugosa, are viviparous, the upper part of the body in the cavity of the shell being filled with living young at the end of summer.

The colour of the common English $L$. retusa agrees with the colour of the shell; thus the orange animals have orange shells, the dusky ones dusky shells. Other species, as $L$. vulgaris, appear to be more permanent in their colour; its animal is always varied with black lines.

Mr. W. Thompson obtained at Weymouth several examples of Littorina rudis in copulation with L. littoralis (Nerita l.); in every instance $L$. rudis was the male. He remarks, "From these instances, I infer $L$. palliata to be the hybrid progeny of $L$. mudis and a female L. littoralis. The only doubt in my mind as to this inference is, that I have not as yet found any specimens of $L$. palliata on this coast; but neither have I found any other shell that might in any way be considered as the produce of $L$. rudis and $L$. littoralis. I found in all eight couples: the probability of some being unfruitful, and the further probability of the hybrids not being prolific, will, I think, form just grounds for the rarity of the species." - Ann. \& Mag. Nat. Hist. 1852 , ii. 76 .

Littorina peruviana is abundant in the anfractuosities of rocks so high above the highest water mark, that they can be only wetted by the spray during tempests; if placed in sea water, they develope themselves and quickly search for means of escaping from it and reach some dry place. $L$. araucana lives on rocks near the high water line, and $L$. umbilicata is numerous in Peru near the low water mark.-D'Orbigny.

\section{Lithoglyphus.}

Eyes basal. Shell ovate, solid, covered with a brown periostraca ; mouth ovate; lips thick. Operculum ovate.-Adams, Gen. Moll. t. 35 . f. 1 a. Fluviatile.

1. L. piscium, t. 124 . f. 5.

2. L. Lapidum, t. 124. f. 4.

The snout of Lithoglyphus Lapidum and L. piscium is rather produced in front, as far or farther than the edge of the foot, annulated. above. The tentacles are subulate, with the eyes on a slight prominence at the hinder outer side of their base. Operculum horny.

Lithoglyphus piscium lives on stones in the little marshes of the river La Plata, and affords food to the Bagri or Siluri. Lithoglyphus peristomatus lives in deep water in the river Parana attached to stones; they live in large families, each shell supporting the oval eggs. They are only to be procured when the river is low.

Dr. Philippi has placed Lithoglyphus and Hydrobia with spiral opercula as subgenera of Paludina, and Paludomus with an annular operculum as a subgenus of Melania.-Handb. der Conch. 167, 168, 1853. 


\section{Hydrobia.}

Shell ovate ; spire conical ; mouth ovate; lips simple. Operculum ovate, of few whorls.

1. H. parvula, t. 123. f. 7 .

2. H.? subumbilicata, t. 123. f. 3 .

\section{Amnicola.}

Shell ovate, conic, perforated; whorls rounded; mouth roundish ovate; lips simple. Operculum oblong, of four or five rapidly enlarging whorls.-Adams, Gen. Moll. t. 35. f. 11 a.

1. A. porata.

Head of Amnicola protruding beyond the foot. Tentacles short, filiform, unequal; eyes at the outer side of the base. Foot elongated, rounded behind, with produced angles in front.

Living crawling on stones, sticks and aquatic plants in rivers and ponds, and often swimming in an inverted position on the surface of the water. The head precedes the animal as it walks. The tentacles are unequal in length. They are oviparous.

\section{Nematura.}

Shell oblong, compressed; spire elongate ; peristome continuous ; mouth roundish, contracted. Operculum ovate, thick, shelly; whorls three, rapidly enlarging.-Adams, Gen. Moll. t. 36. f. $5 a$, $b$. Fluviatile.

1. N. Deltæ, Adams, Gen. Moll. t. 36. f. 5 (shell only).

2. N. polita.

They live in rivers and streams in the East, and are found adhering to the under surface of dead floating leaves.

\section{Risella.}

Eyes rather above the base of the tentacles. Shell trochiform, imperforated; whorls angular, flattened in front; aperture rhombic, smooth internally. Operculum ovate.-Adams, Gen. Moll.t. 33.f.5 a.

Fig. 50.-Teeth of Risella melanostoma.

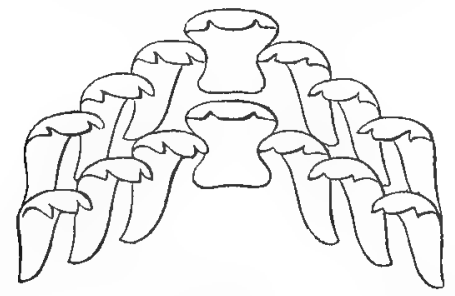

Lingual membrame narrow, elongate. Teeth very transparent, subsimilar, tridentate (fig. 50). 
1. R. melanostoma, t. 51, f, 11 .

2. R. aurata, t. 51 .f. 10 ; f. 14 , variety of preceding?

3. R. lutes, t. 51. f. 12 .

These mollusks appear to take the place of our periwinkles on the Australasian coast.

†† Operculum subcircular, of few rapidly enlarging whorts.

\section{Pagodus.}

Shell top-shaped, muricated, imperforate; whorls subangular in front; inner lip rather callous in front, outer striated internally. Operculum ovate, subcircular; whorls rapidly enlarging; edge thin;

1. P. verus, t. 82. f. 1, 4 ; ddams, Gen. Moll. t. 33. f. 2.

2. P. - , n. s. t. $126 a$. f. 4 .

The foot of Payodus verus is short, simple; side of the body quite simple. Mouth short, annulated, the lingual baud extremely long. -Quoy, t. 62.f. 31. Tentacles conical, distant at the base, with eyes or small tubercles on their outer bases. Penis large, club-shaped, placed a little below and behind the right tentacles, conical, covered with minute spicula at the tip, and with two large spinose prominences almost one-third down the hinder edge. Operculum suborbicular, thin, horny, of three or four rapidly enlarging whorls.

\section{+十 Operculum circular, many-whorled.}

\section{Echinella.}

Eyes —_ ? Shell top-shaped, tubercular, perforated; aperture ovate; inner lip arched, edentulous. Operculum annular, of many whorls.-Adams, Gen. Moll. t. 33. f. 3 a.

1. N. Cumingii.

\section{Modulus.}

Eyes half-way up the tentacles. Shell top-shaped or depressed, perforated; aperture oval ; inner lip deeply notched. Operculum circular, of many whorls.-Adams, Gen. Moll. t. 33. f. 4.

1. M. retusus. M. tectum, Adams, Gen. Moll. t. 33. f. 4.

2. M. trochiformis, t. 126 a. f. 1 .

3. M. lenticularis, ddams, t. 33. f. $4 a$ (shell only).

The teeth of Modulus lenticularis are in seren series, $3 \cdot I \cdot 3$; the central broad, denticulated; outer lateral curred, elongate.-Morch.

\section{b. Tentacles with a basal internal lobe. Eyes basal.}

\section{Fossar.}

Shell half-ovate, costate, perforated; mouth half-ovate ; lips thick, outer simple. Operculum orate.-Adams, Gen. Moll. t. 33 . f. 7 a. 1. F. ambigua, t. 51.f. 7, t. 125.f. 7 ; Adams, Gen. Moll. t. 33.f. 7. 
Head of Fossar ambigua proboscidiform, produced. Tentacles filiform, pointed, with an internal frontal lobe ; eyes not prominent, at the outer base of the tentacles. Foot moderate, rounded at each end. Operculum horny, semiorbicular, simple, not spiral. Shell semiglobose, umbilicated. Mouth large, semicircular; lip toothless, not calluus. Umbilicus open, outer lip acute, smooth within.Philippi.

\section{Fam. X, LACUNID E.}

Mantle enclosed, simple-edged. Trunk produced, wrinkled, not retractile. Jaws none. Tongue linear. Tentacles far apart. Gills single, of numerous strands. Operculigerous lobe expanded at the side, and furnished with two beards behind. Shell solid, spiral, free; aperture ovate; inner lip flattened, groored. Operculum spiral, horny, few-whorled.

\section{Lacuna.}

Shell conical or subglobose; spire short; mouth half-ovate; inner lip flattened, with a deep umbilical groove.

1. L. canalis, Wiegm. Arch. 1836, t. 8. f. 5.

2. L. vincta, Forbes \& Hanley, B. M. t. G.G. f. 4.

3. L. divaricata, Adams, Gen. Moll. t. 33. f. 6.

The Lacunce are robust; the head strong, thick; eyes nearly sessile; tentacula long, slender; male organ at the base of the right tentacula, strong, compressed, thick, long; operculigerous lobe with a styliform beard on each side; sole panduriform. Living on Fuci; on brown Fuci they are green, on red Fuci rose-coloured. The eggcases are worm-shaped, thick, curved into a semicircle. The young swimming, with a vibrating veil.-Lovèn, Ind. Moll. Scand. 22.

Lacuna pallidula is pale flesh-coloured. Rostrum very short; mouth orbicular, radiately plicated, emitting an elongated cylindrical proboscis. Tentacles lateral, elongate, filiform, tapering, slender, with the eyes on a short swollen tubercle on the outer side of their base; sides of body simple. Foot oblong, rounded before and behind. Opercular disk expanded, with a slight filiform process on each side behind. The foot is quite continuous, sometimes regularly gliding along in walking, and at others alternately moving first one side of the front margin and then the other. They are very impatient when in the water, and desirous of getting out of it, sometimes floating on the surface like Lymnec; very viscid. The gills are enclosed on the left side of the cavity. These animals differ from Littorince in the shape of the mouth, in having a proboscis, and in the hinder lobe of the opercular mantle. The proboscis has not been observed by any other malacologist, and I have not the means of verifying the fact at present; but the absence of jaws renders it probable they should be removed to the former order.

The operculigerous lobe of Lacuna pallidula is expanded laterally 
into minute wing-like processes, and at the terminal point is subcircularly scalloped out, the lateral margins forming usually four, sometimes three or four, very short caudal fillets, sometimes either rudimentary or quite obsolete. The single respiratory plume, branching from right to left, has 35 to 45 or more long slender pectinations ; the neck is simple and free from all lappets.-Clark.

Lacuna pallidula, L.vincta, and $L$. crassior have no jaws; the teeth are nearly alike in the three species, in from 45 to 60 cross rows; in $L$. crassior the central tooth is higher than in the others. 'The otolites are circular and simple.-Alder.

In Lacuna puteolus the lateral appendages of the operculigerous lobes are large, but the caudal flament very short, and often obsolete. L. pallidula has the lateral wing-like extension with two or four very short caudal lobes.-Clark.

The foot of Lacuna pallidula has a longitudinal fissure, and the progression is alternate as in Littorina; branchial plume single, of 35 to 45 or more long slender pectinations ; neck simple, without lappets. The verge elongate, simple, under the right tentaculum. Operculigerous lobe bifid behind.-Clark.

The central tooth of Lacuna canalis (fig. 51) is almost hexagonal ; cutting edge with five pointed lobes; first lateral tooth behind deeply notched between the two processes, the upper margin five- to six-

Fig. 51.-Teeth of Lacuna canalis.

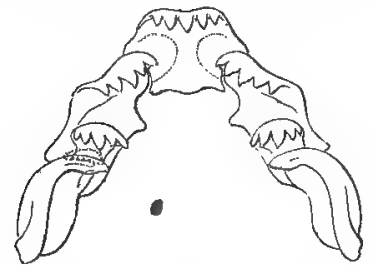

toothed; the second slender, subclavate, five-toothed; the third clawlike, the anterior margin somewhat toothed before the tip.-Lovèn.

The Lacune feed on Fucus, eating the surface of the frond or stem, often forming holes through the former and deep holes in the latter, into which many specimens often crowd themselves. 'They are also often found crowded together in the crevices among the roots of the plant. The animal has no filament on the end of the foot.

The Lacunce live among the roots of Laminaria and other marine plants, attached to stones and shells below the low tide level, but the Fuci are often found, dragged by the storms, on sandy beaches.

\section{Fam. XI. TRUNCATELLIDA.}

Shell spiral ; whorls gradually enlarging. Apex acute, deciduous. Aperture ovate. Peristome continuous. Muzzle broadly two-lobed. 
Jaws distinct. Tongue linear. Tentacles compressed, short, diverging. Eyes large, black, with a peculiar, very visible, prominent white pupil on the outer side of the hinder part of the base of the tentacles. Foot very short, rounded. Operculigerous lobe simple. Operculum horny, ovate, of few whorls. Walks with its foot, its dilated lips forming an intermediate loop.

\section{Truncatella.}

Character of the Family.

1. T. truncatula, t. 123 . f. 14, t. 125. f. 14 ; Forbes \& Hanley, B. M. t. F.F. f. 10 .

2. T. littorina, t. 125 . f. 6 .

3. T. atomus, t. 125 . f. 15 .

4. T. littorea, Forbes \& Hanley, B. M. t. M.M. f. 3.

Teeth of Truncatella Montagui $3 \cdot 1 \cdot 3$; the central rather narrow, with a recurved central tooth; lateral inner broad; inner upper edge with three broad denticles; central rather like inner, but narrower and more oblique; outer conical, compressed, curved; apex denticulated beneath.

The mantle of Truncatella Montagui is plain; rostrum annular, long, very broad, flat, nicked at the end, and auricled on each side. Jaws white. Branchial plume single, elongated, kidney-shaped. Tentacles short, flat, subtriangular. Eyes black, large, pupils white, on middle of tentacles. Foot thick, oval, very little extended.Clark, 383.

The eyes of Truncatella littorea white, with dilatable white pupils as in T. Montagui, near the tip of the broad, short tentacles. Foot thick, elongated, oval, and looped in its walk.

"Tentacula perbrevia ad latera capitis dispositis divergentia, oculos in latere superiore neque exteriore gerentia, caput in proboscidem bilobam, tentaculis longiorem productum. Pes admodum brevis, ellipticus, utrinque rotundatus, ex observatione cl. Lowe (Zool. Journ. v.) quam transcripsit Desh. (Ed. 2. Lamk. viii. 363) sulco mediano transverso divisus, quod ipse non vidi, sed erroneum putaverim, cum animal prorepens sicut Paludince parvæ, capite molem corporis falciatur." - Philippi, Sicil. ii. 133.

\section{Tovichia.}

Proboscis nicked. Tentacles blunt. Foot short, ovate, lobed on each side in front. Shell elongate, perforated, truncate; periostraca olive; mouth elliptical, oval. Peristome double or triple, continuous; left lip expanded, rather reflexed, slightly nicked. Operculum horny, ovate, subspiral.

1. T. ventricosa, Benson, Ann. \& Mag. Nat. Hist. 1851, 378. 
c. Gills of a few, twelve to fifteen, lamince in regular descending spiral series on the left side of the mantle-cavity. Operculum distinct. Mouth of shell contracted, moderate, roundish (pp. 78, 86).

* Operculum spiral.

Fam. XII. PLANAXIDA.

Rostrum elongate. Tentacles subulate. Eyes sessile, basal, exterior. "Gills in several lines," laminar. Mantle edge simple, with a recurved-siphon in front. Shell conical, solid, spirally striated; aperture oblong, with an anterior notch ; inner lip concave, flattened. Operculum ovate, subspiral.

Marine.

a. Planaxina. Opercular mantle simple. Amphibious.

\section{Planaxis.}

Shell conical; spire acute; mouth oblong; inner lip concave, simple; outer lip grooved within. Operculum ovate._Adams, Gen. Moll. t. 34. f. 2 a.

1. P. pyramidalis. P. sulcatus, Quoy, t. 24. f. 6.

2. P. nigra, Quoy, t. 24. f. 3, cop. Adams, t. 34. f. 2. On seashore on stones and plants, often left dry by the tide.

Lingual membrane of Planaxis sulcata with seven teeth, $3 \cdot 1 \cdot 3$; central with a recurved apex, three-dentate, central largest; inner lateral rather broad, with a recurved apex, rather oblique, and with a tooth on its outer edge; outer straight, one-third the width of the inner, with a slightly recurved apex.

\section{Quoyia.}

Shell conical, turrited, solid, spirally striated; mouth small, oblong, with a small notch in front; outer lip simple; pillar-lip thickened, rather flattened, concave, with a deep notch in the centre. Operculum horny, ovate, thin, subspiral.

1. Q. decollata, t. 24. f. 4, cop. Adams, t. 34.

The foot of Quoyia is small, ovate, folded across, and crumpled in front; body quite simple on the sides. Rostrum short, ringed. Tentacles slender, conical, far apart at the base; eyes on short tubercles at their outer base. Mantle simple, with a groove at the left angle, without any appearance (when in spirits) of a distinct siphon as in Planaxis. Operculum half-ovate, subspiral, of one and a half or two whorls; nucleus subapical.

The shells only differ from Planaxis in having a large groove on the hinder part of the inner lip, which is continued up the pillar, (and is equally to be observed in the young shell,) and in the very small size of the anterior canal. The operculum is said to have a 
notch to fit this groove, but this was not the case with our specimen, and was perhaps an accident in the one described.

They are amphibious, and are found in shallow pools at the roots of the mangroves, or adhering to stones far inland and exposed to the sun.

\section{b. Litiopina. "Opercular lobe bearded."-Eydoux. Pelagic, floating.}

\section{Litiopa.}

Shell thin, conical; spire acute; mouth ovate, nicked in front; outer lip simple, acute. Operculum horny. Mantle bearded.

1. I. bombyx, t. 24. f. 1, 2.

2. L. melastoma, t. 107. f. 3, cop. Adams, Gen. Moll. t. 34. f. 5.

Small animals are found on the Gulf weed, to which they attach themselves by means of a byssus which they secrete.

The operculum of Litiopa was overlooked by MM. Rang and Kiener. Prof. d'Orbigny $(C u b a, 148)$ states that he observed it in all the specimens given him by M. Rang, so that all the reflections made by $M$. Rang respecting its absence at once fall to the ground. He also observes that the two species described by the same author are only varieties, occasioned by difference of age, of the same kind, viz. $L$. bombyx of Kiener. The shells of the young animals are longitudinally grooved or costated.

\section{Fam. XIII. RISSOAD五.}

Rostrum produced, adherent to the front of the foot beneath. Jaws horny. Teeth $3 \cdot 1 \cdot 3$; outer lateral denticulated. Tentacles setaceous; eyes sessile, basal, external. Foot short, truncated in front; opercular mantle rather expanded, often furnished with one or two posterior processes. Operculum horny, spiral. Shell ovate, costated, white, covered with a thin periostraca. Mouth ovate, sim. ple, with a slight canal in front.

+ Operculum ovate, with an internal process on the front edge. Mouth subtruncate in front.

\section{Rissoina.}

Animal _—? Operculum semilunar, subspiral ; inner side with a longitudinal muscular impression and an elongated process before it as in Nerita. Shell turrited, ribbed or cancellated; spire pointed; aperture ovate, effused interiorly, slightly channeled in front; outer lip dilated anteriorl 5 , thickened internally.

1. R. Cumingii, Adams, Gen. Moll. t. 35. f. 1 (shell only).

2. R. Inca, d' Or.b. Amér. Mérid. t. 53. f. 11-16 (shell only).

These animals live, affixed to stones on rocks at the common low water line, on the coast of Peru. 
†† Operculum ovate, subspiral, simple.

2. Rissoa.

Foot with single dorsal posterior process. Shell ovate, solid; spire short, smooth or plaited; aperture ovate, rounded in front; outer lip more or less dilated, thickened externally. Operculum ovate.

1. R. auriscalpium, t. 125. f. 13 .

2. R. monodon, t. 125. f. 9 ; Adams, Gen. Moll. t. 35. f. 2.

3. R.? inconspicua, t. 125 . f. 5 .

4. R. abyssicola, Forbes $\&$ Hanley, B. M. t. J.J. f. 3, cop. Alvanea a., Adams, Gen. Moll. t. 35. f. 3.

5. R. Cingillus, Forbes \& Hanley, B.M. t. J.J. f. 4. Cingula c., Adams, Gen. Moll. t. 35. f. 8 .

6. R. parva, t. 123. f. 8 ; Forbes \& Hanley, B. M. t. J.J. f. 5.

7. R. labrosa, Forbes \& Hanley, B. M. t. J.J. f. 6.

8. R. rufilabris, Forbes \& Hanley, B.M. t. J.J. f. 7.

9. R. Ulvæ, Forbes \& Hanley, B. M. t. J.J. f. 8. Hydrobia U., Adams, Gen. Moll. t. 35. f. 10.

Fig. 52.-Teeth of Rissoa membranacea.

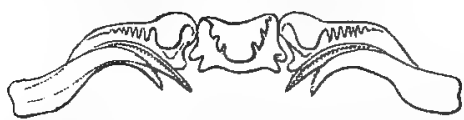

Central tooth of Rissoa membranacea subquadrate, the. base wide and somewhat projecting, with a short lateral process on each side; cutting edge longly recurved, the tip widely lobed and inciso-dentate on each side ; lateral teeth somewhat transverse, the first produced; margin before the strong lobe pectinate-dentate; second and third almost claw-like, the former serrated, the latter serrulated in front (fig. 52).

Animal of Rissoa striata whitish. The rostrum short, rather deeply bifid at the end. Tentacles rather long, subcylindrical, white; eyes black, very distinct, sessile, a little above the outer side of the base. Foot oblong, slender (interrupted ?), rather tapering behind, sides simple. Opercular mantle simple. Operculum ovate, horny.

Foot of Rissoa interrupta elongated, rather tapering behind, divided across in front by a transverse interruption, the front division about one-third the length of the rest, separation marked by a pellucid line; the hinder part whitish, with a transparent central longitudinal line. The foot very flexible, moving almost independently of the body. Rostrum short, divided into two parts by a central longitudinal slit, and not a radiated plait like Lacuna. Floats like Lymnea.

Teeth of Rissoa interrupta in forty or fifty rows, $3 \cdot 1 \cdot 3$; central transverse rounded, with three recurved apical dentations, and two on each side of the base. Lateral teeth : inner broad, its inner upper edge dentate, outer linear; second bifid at the tip, outer simple. Prehensile collar distinct.-Alder. 
Operculum of Rissoa costulata ovate, of two and a balf rapidly enlarging whorls; the hinder end subangular. Teeth $3 \cdot 1 \cdot 3$; central broad, apex recurved, with five denticulations, the central broadest; lateral inner broad; upper inner edge reflexed, toothed; middle similar, narrower ; outer linear, end reflexed, denticulated.

The branchial plume of Rissoa reticulata is composed of 12-15 single short strands. The mantle has a filamentary process at the angle of the aperture.-Clark, 364 .

The branchial plume of Rissoa parva consists of 15-18 minute ressels attached under and to the mantle and back of the neck. The operculigerous lobe dilates into subcircular lateral wings, bearing close at the junction of the foot and the body the subovate paucispiral operculum and a caudal cirrhus.-Clark, 356 .

Head of Rissoa violacea and $R$. Montagui simple, without appendices, emarginate. Tentacula subulate, nearly as long as the foot. Eyes at the outer base. Foot oblong, truncated in front, slender behind.

The tentacula of Rissoa proxima are flat, short, smooth, subclaviform, with long setæ. Eyes very large, on the subsemicircular lateral external basal excrescences. Fcot large, fleshy, grooved, and longly auriculated in front, and divided behind into two distinct tails. Opercular lobe small, without a caudal cirrhus. Operculum of four to five whorls, the last suddenly enlarged.-Clark, 368 .

Mantle of Rissoa unica is simple, with a filament like Rissoa near the sutural angle. Muzzle slender, rather long. Jaws and lingual riband distinct. Tentacles subulate, obtuse, smooth, with no connecting tentacular veil or any foldings or apical inflations as in Chemnitzia. Eyes central, basal. Foot slender, deeply labiated, longly auricled in front. Operculigerous lobe simple, without lateral expansion or terminal filament. Operculum ovate, paueispiral. When it walks, the eyes are usually under the margin of the shell. It has no malacological community with Aclis or Chemnitzia, but the muzzle is carried in nearly a similar position as in the latter genus. We must not be misled by the centrality of the eyes at the base of the tentacula, as the vertical cloven disk and corneous jaws, with the simple tentacula, demonstrate that it is merely a Rissoa. Mr. Clark considers Skenea planorbis as a discoidal, and Cerithium reticulatum and Aclis unica as turrited Rissoc.-Moll. 373.

$++\dagger$ Operculum subcircular, simple; whorls many, gradually enlarging. Aperture of shell circular, simple.

\section{Skinnea.}

Rostrum short, thick, nicked at the end. Tentacles subulate. Eyes basal, exterior. Foot elongate, truncate in front, tapering behind. Opercular mantle with a rounded wing on each side, produced lanceolate behind.-Lovèn. Operculum circular, of many whorls (Adams, Gen. Moll. t. 35. f. 9 a). 
1. S. planorbis, Forbes \& Hanley, B. M. t. G.G. f. 1, cop. Adams, Gen. Moll. t. 35. f. 9.

The shell of Skenea depressa is blackish when alive. Operculum horny, circular. Tentacula two, filiform, white, rather short; the eyes at their external base sessile. Mouth proboscidiform. Foot short, tapering posteriorly, with plain margins. The animal swims with great facility in a reversed position, and in structure appears to be almost identical with Rissoa. It is found on flat rocks between tide marks in Berwick Bay in great profusion.-Johnston, Proc. Berwo. N. $C l u b$, i. 273.

Dr. Lovèn also observes that the animal of Skenea depressa is like Rissoa ; the operculigerous lobe with a rounded wing on each side, produced and lanceolate behind; and Mr. Clark considers it a depressed species of that genus.

Jaws (or prehensile collar) of Skenea planorbis tubercular, distinct. Teeth are $3 \cdot 1 \cdot 3$, in about 20 or 30 rows ; central four-sided, rather broader than long; apex rounded, recurved, three-toothed, and with a tooth on each in front of the base; lateral subulate, compressed, rather broad at the base, slender and curved at the tip.-Alder.

Mantle of Skenea planorbis simple. Muzzle produced, vertically cloven. Jaws horny; tongue spinose. Tentacles short, flattish, not setose. Eyes large, black, external, basal. Foot long, slightly auricled. Operculigerous lobe much expanded, dilated into a subrotund form behind, like the sole, with a very obsolete beard. Operculum suborbicular, of many rapidly increasing whorls._Clarke, 373 .

Aperture of the shell of Skenea depressa is subcontinuous, circular. Operculum transparent, horny, pale yellow, orbicular, of a few rapidly enlarging whorls. Animal : Tentacles two, subcylindrical, filiform, blunt, transparent. Eyes distinct, a little above the outer base of the tentacles. Trunk short, protruded, apex nicked at the tip. Foot oblong, continuous, rather narrow, slightly truncated in front, and rather tapering behind. Opercular mantle nearly twice as wide as the foot, making a white fringe to the operculum, without any processes. Foot folded across when contracted : the places of the fold look sometimes as if the foot was interrupted there, and there is a central longitudinal transparent line in the hinder part of the fold.

\section{Fam. XIV. CAECID五.}

Shell subcylindrical, arched; apex subspiral, deciduous, the dorsal surface convex. Operculum horny, circular, spiral. Proboscis thick, truncate. Tentacles subulate, lateral. Eyes basal, exterior. Foot short, truncate in front, acute behind. Gills laminar? Jaws distinct. Teeth $3 \cdot 1 \cdot 3$; lateral subulate, curved.

The branchial leaflet of Cacum and Brochina is very minute, appearing like two, one larger than the other. Foot regular in shape, but singularly short both before and behind. 


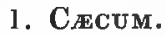

Operculum concave externally, smooth.

1. C. imperforatum, Forbes \& Hanley, B. M. t. K.K. f. 1, cop. Adams, Gen. Moll. t. 38. f. 6.

Animal of $C$. imperforatum cylindrical, arcuated. Mantle thick, fleshy. Head long, flat, assisting in locomotion. Mouth vertical. Tentacula short, thick, subcylindrical, setose, slightly clavate. Eyes very minute, sessile, in a line with and a short distance from their base. Neck slender, with two longitudinal ridges from eyes. Foot short, narrow, truncate in front. Gill on left side pale red; branchial leaflets two, one large, the other small, as in Gasteropodan Canalifera. Shell with convexity upwards. Operculum circular, horny, black-brown, concave without, with close spiral lines on back of foot.

$C$. trachea is the young of $C$. imperforatum, thrown off as the shell grows.

Animal marches with great vivacity, carrying the shell sometimes with the convexity upwards, resting on the posterior point or on one of the sides, frequently changing one for the other by suddenly withdrawing the head and body and turning on the side it wishes.

The foot of Cacum trachea is short, narrow, and truncate anteriorly, sloping behind to an obtusely pointed termination. Operculum strong, circular, corneous, of seven or eight close-set spiral whorls. The tentacles are elongate, diverging, thickened, and a little spread at the bases. The eyes have decidedly an external bias. The operculigerous lobe is certainly without a cirrhal appendage._Clark, Moll. 518, Append.

Mr. Alder was only able to examine the jaws and teeth of Cacum trachea very imperfectly; there are a number of elongated linear curved teeth, which appear like the outer lateral ones.

The animal of Cacum pulchellum of New England, found adhering to $V$ ermeti, agrees nearly with the English species $C$. trachea, as described by Mr. Clark. The head projects a little in advance of the foot, which is short. The muzzle is cleft and transversely wrinkled, and has two black spots above just in front of the tentacula, which are thick, curved, and covered with large vibrillæ. The eyes are conspicuous, black, oval, and situated at nearly the middle of the bases of the tentacula, a little towards the inner sides. The operculigerous lobe projects a little beyond the operculum. The operculum multispiral, of almost eight rolutions, corneous, and concave on the outer surface. The shell in its adult state is clavate, arcuated, contracted at both extremities, and having a somewhat angular appearance at its outer or dorsal outline, thick and strong, with strong rounded ribs, broader in front.

Mr. Stimpson observed, while keeping this species alive from April to November, that it presented three stages of growth: first, a slender, thin, arcuated form, with few distant ribs ; secondly, the anterior half of the former form left by the decadence of its posterior half, with a part of the growing adult shell; and thirdly, the adult shell, which is clavate, arcuate, contracted at both extremities, and 
having a somewhat angular appearance on the longer outer or dorsal outline. It is thick, strong, pale yellow, with about twenty-five strong rounded ribs, broader anteriorly. Thus the septa of the shell would appear to be thrice formed.-Stimpson, Shells N. Eng. 36, 1851 .

The apex of the shell of Cacum, according to Dr. Shuttleworth, is subspiral, the whorls being separated from each other, the tip gradually falling off. One of the species described by Stimpson is ovate, veatricose.

When examining Mr. Bean's cabinet in 1850, I noted Vermicularia incurva. It appears to be the young of Caeum; the apex is spiral, the straight part is slightly transversely annulated.

\section{Brochina.}

Operculum convex externally, with a succession of spiral terraces. 1. B. glabra.

Operculum of Brochina glabra shaped like that of Siliquaria, of five or seven coils rolled round a windlass, crenulated at the edges, mammillated above and below, and on the summit are numerous loculi, like those in the centre of Polystomella.-Clark, Moll. 326.

Mr. Clark considers the Cacidas as very nearly allied, if not identical with $V$ ermetus; that they are probably attached when young (?), and at lerigth become free, all other attached shells being free when first hatched; and lastly, that Skenea rota, which is free (!), is perhaps the young of C. glabrum.-Moll. 325 .

\section{Fam. XV. MELANIAD卌.}

Gills in a single series of a moderate number of cylindrical rigid plates. Mantle edge torn, with a more or less distinct siphon in front. Rostrum produced, annulated. Tentacula subulate. Eyes on the outer side of the base of the tentacles, sessile, or on short tubercles. Shell spiral, turrited, covered with an olive periostraca ; aperture ovate or circular. Operculum spiral.

Fluviatile.

a. Aperture of shell ovate, entire in front.

\section{Melania.}

Shell ovate or turrited; spire acute; mouth ovate, entire in front. Operculum ovate, of few whorls. Rostrum wrinkled, elongate, nicked. Tentacles filiform, with the eyes on the outer side of the base. Foot moderate, ovate, rather square in front. Often viviparous.

1. M. amarula, t. 127 a. f. 6; (Tiara a.), Adams, Gen. Moll. t. 31 . f. 3 .

2. M. setosa, t. 55. f. 2,11 . 
3. M. virgulata, t. i27 a. f. 8.

4. M. erythrostoma, t. 55. f. 3 .

5. M. truncatula, t. 55. f. 5, 12 .

6. M. uniformis, t. 55. f. 6 .

7. M. spinulosa, t. 55. f. 7 .

8. M. costata, t. 55. f. 8 .

9. M. granifera, t. 55. f. 9 .

10. M. molluccensis, t. 55. f. 10 .

11. M. glans (Melanella gi.), Adams, Gen. Moll. t. 31. f. 4.

12. M. hastata, Adams, Gen.Moll. t. 32. f. 1 ; Fig.Moll.t. 226 a.f.7.

The teeth of Melania — ? in seven series, $3 \cdot 1 \cdot 3$; the central with five reflexed, rounded denticles; the outer lateral teeth linear, with the end dilated and edged with rounded crenations.

\section{Melanatria.}

Shell subulate, nodulose; spire acute; aperture roundish ovate, produced in front; outer lip rather produced in front. Operculum subcircular, of few rapidly enlarging whorls.

1. M. fluminea.

2. M. variabilis, t. 127 a.f. 7. Melanoides indica, Adams, Gen. Moll. t. 31 . f. 5 .

3. M. Touranensis, Eydoux, Voy. Bon. t. 31. f. 47.

\section{Pachycheilus.}

Shell conical, smooth, solid; aperture ovate, roundish; pillar-lip thickened behind; outer lip thickened. Operculum subcircular; whorls three to four, very rapidly enlarging. - Adams, Gen. Moll. t. 31 . f. 7 .

1. P. lævissimus.

\section{Leptoxis.}

Shell ovate or subglobose, solid, subperforated; spire short; mouth ovate, rounded in front; inner lip callous, especially behind; outer lip sinuous. Operculum half-ovate, subspiral.-Adams, Gen. Moll. t. 22. f. 6 .

1. L. prærosa.

The Leptoxes are sedentary freshwater animals, living in very rapid streams attached to stones.

b. Aperture of shell with an indication of a canal in front.

\section{Ceriphasia.}

Shell fusiform, sulcated, covered with a dark green periostraca; whorls angulated in front; aperture small, produced in front, with a groove-like canal; outer lip sinuated behind. Operculum ovate, subspiral.

1. C. sulcata. C. canaliculata, Adams, Gen. Moll. t. 31 . f. 6. 
c. Aperture ovate, truncate in front.

6. Gyrostoma.

Shell ovate, turrited, grooved ; mouth oblong; inner lip thickened, callous behind; outer thin, with a deep posterior fissure; mouth ovate, subtruncate in front. Operculum half-ovate, subspiral.Adams, Gen. Moll. t. 32. f. 4.

1. G. ovoideum.

\section{Hemisinus.}

Shell ovate, turrited, smooth; mouth ovate, contracted, produced and truncated in front; outer lip simple, crenated. Operculum half-ovate, subspiral._Adams, Gen. Moll. t. 32. f. 2.

1. H. lineolatus.

\section{d. Aperture of shell with a distinct notch in front.}

\section{VIBEX.}

Shell turrited; whorls costate, tuberculated; mouth subcircular, produced, and broadly channeled in front; outer lip thin, sinuous. Operculum half-ovate, subspiral.-Adams, Gen. Moll. t. 32. f. 3.

1. V. aurita, t. 54. f. 8 .

2. V. Owenii, t. 54. f. 1.

3. V. celebensis, t. 55. f. 4.

\section{Faunus.}

Shell turrited, acute; whorls flat; lips thick, outer dilated, sinuated behind. Operculum half-ovate, subspiral.-Adams, Gen.Moll. t. 32 . f. 9 .

1. F. ater, t. 55. f. 1 .

Lingual membrane of Faunus ater elongate, transparent. Teeth $3 \cdot 1 \cdot 3$, very transparent; central rather far apart; apex recurved,

Fig. 53.-Teeth of Faunus ater.

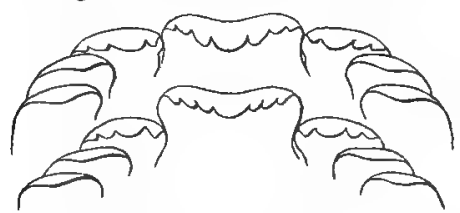

five or seven-toothed; the central lobe broad, rounded, the lateral small, rounded. Lateral teeth: inner oblong, inner part of apex recurved, lobed like central tooth; two outer elongate, very slender, subulate, nearly equal, curved at the end (fig. 53).

\section{Melanopsis.}

Shell ovate; spire conic, short, often plicate mouth elongate, 
oblong; inner lip thick, callous behind; outer simple, acute. Operculum half-ovate, subspiral; apex curved.-Adams, Gen, Moll. t. 32 . f. 8 .

1. M. costata.

Foot broad, truncate, ovate. Head proboscidiform. Tentacles setaceous. Eyes exterior, basal. Tongue linear, ribbon-like; apex at each side membranaceous. Teeth in seven series; central and inner lateral fixed; outer lateral versatile; central transverse, subquadrate, five-hooked; central hook very large ; the first lateral hook bipartite, rather six-hooked; the second hook the longest; the two or three lateral teeth subequal, with three hooks in front. Operculum horny, half-ovate; apex subspiral-_Rossmäsler, Icon. iii. t.68. f. 836 .

Central tooth of Melanopsis buccinoides transverse, subquadrate, somewhat prominent at the base in the middle, cutting edge trans-

Fig. 54.-Teeth of Melanopsis buccinoides.

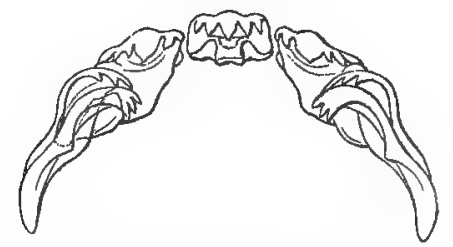

verse, with five pointed lobes; lateral teeth strong, first thick, with a short projecting process on the inside, the base produced on the outside, the upper margin unequally lobo-dentate, the second and third slender, somewhat similar, arcuate, impressed and thickened in the middle, the tip recurved and three-toothed (fig. 54).

\section{Chionelila.}

Shell fusiform, plicate; whorls with a compressed groove in front; month ovate; outer lip with a deep posterior sinus. Operculum half-ovate; apex subspiral.-Adams, Gen. Moll. t. 32 . f. $10 a, b$.

1. C. sinuata. Pleurotoma buccinoidea, Quoy, t. 90. f. 5 ; Adams, Gen. Moll. t. 32. f. 10.

\section{e. Aperture of shell with a straight canal in front.}

12. Io.

Shell fusiform; whorls angular, tubercular; mouth ovate, large, dilated in front; canal rather produced; outer lip simple. Operculum ovate; whorls three or four, very rapidly enlarging. - Adans, Gen. Moll. t. 31 . f. 8.

1. I. fluviatilis. 


\section{Fam. XVI. CERITHIAD压.}

Rostrum wrinkled, produced. Tongue linear. Teeth $3 \cdot 1 \cdot 3$. Tentacula lateral, subulate. Eyes on the outer side of the base. Gills in a single series of cylindrical, rigid plates. Foot short, broad. Operculum horny, spiral. Shell ovate, covered with a thin periostraca. Mouth ovate or subquadrate, more or less channeled in front; outer lip often expanded.

\section{* Operculum ovate.}

\section{Rhinoclavis.}

Shell ovate, turrited, with rudimentary varices; aperture ovate; canal straight, recurved; pillar lip thickened. Operculum ovate.Adams, t. 29. f. 7.

1. R. diemensis, t. 54. f. 5 .

2. R. vertagus, t. 54. f. 3 ; Adams, Gen. Moll. t. 30. f. 1. Operculum oblong, subannular.

3. R. aluco, t. 54 . f. 7 .

4. R. vulgatus, t.52. f. 5, t. 53. f. 6, 8, 9 ㅇ d, t. 173. f. 3 ; Adams, Gen. Moll. t. 29. f. 7. Operculum subspiral.

5. R. lemniscatus, t. 52 . f. 9 .

6. R. brevis, t. 52 . f. 8 .

T. R. morus, t. 52. f. 7.

8. R. Touranii, t. 127 a.f. 9.

** Operculum semicircular, of few rapidly enlarging whorls.

\section{Cerithium.}

Shell turrited; canal slightly recurved.

1. C. nodulosum, t. 52. f. 9 , t. 54. f. 6 .

2. C. læve, t. 52. f. 6 .

Teeth of Cerithium $3 \cdot 1 \cdot 3$, dark brown; central transverse with five denticulations, the central large, broad, the lateral close, smaller; inner lateral teeth small, oblong, with a sharp tooth on the inner edge ; outer lateral curved, subulate, acute.

Cerithium varicosum and $C$. Montagui are found in the brackish water at the mouth of the river Guayaquil.

Cerithium peruvianum lives under stones at the low water line on the coast of Arica, Peru.

Cerithium atratum and C. guaranianum are found in the Bay of Rio in sandy places near rocks at low water mark. 
*** Operculum circular, of many whorls. Shell turrited, dextral. Mouth subquadrangular, more or less channeled in front. Nape not crested. Tentacles lateral; veil none.

+ Canal distinct, recurved.

\section{Bittium.}

Shell turrited; whorls flattened; aperture ovate; canal moderate, distinct. Operculum circular; whorls rather large.-Adams, Gen. Moll. t. 30. f. 3 .

1. B. reticulatum, t. 54. f. 5, t. 127. f. 4 ; Forbes \& Hanley, B.M. t. I.I. f. 2, t. O.O. f. 3 (operculum); Adams, Gen. Moll. t. 30 . f. 3 .

2. B. diemenense, t. 55. f. 13.

The mantle of Bittium reticulatum is plain, forming a small anterior dilatation to correspond with the shell, not a regular siphon. Muzzle elongate, cloren vertically. , Jaws and lingual riband distinct. Tentacles short. Eyes external, sub-basal. Foot rather short, truncated; operculigerous lobe elongated, narrow before, broader behind. Operculum subcircular, few-whorled.-Clark.

Dr. Lovèn describes the operculigerous lobe of Bittium reticulatum as rather winged on each side, the hinder beard lanceolate, and asks if it is a Rissoa (Moll. Scand. 23). Mr. Clark, adopting the idea, considers it an elongated, turrited Rissoa.

Teeth of Bittium reticulatum $3 \cdot 1 \cdot 3$; the central subquadrangular, transverse (that is, rather broader than high), apex recurved, denticulated; lateral inner tooth rather broad, inner edge recurved, denticulated; outer tooth linear, bent rather like an $f$; the front of the apex (or upper third) denticulated. Operculum spiral, subcircular; whorls four, rapidly enlarging.

\section{Tympanotomus.}

Shell turrited; whorls flat, tubercular; mouth roundish; canal very short, curved; pillar tortuous ; outer lip sinuated, produced in front.

1. T. fuscatus, t. 53. f. 3 .

\section{Telescopium.}

Shell conical, turrited; whorls flat, last angular in front; mouth nearly four-sided; pillar twisted; canal short, curved; outer lip dilated, sinuous.-Adams, Gen. Moll. t. 31. f. 1.

1. T. fuscum, t. 54. f. 2, t. 127. f. 5, t. 267. f. 1.

Lingual membrane of Telescopium fuscum tender. Teeth $3 \cdot 1 \cdot 3$; central small, recurved (denticulated?); inner lateral broader, with a slightly recurved apex to the inner broader end; two outer lateral subulate, arched, incurved. 


\section{Pyrazus.}

Shell turrited; whorls rugose, granulated, variced; mouth subquadrate; canal short; pillar with a central prominence; lips continuous, outer dilated. Operculum circular, of many whorls.-Adams, Gen. Moll. t. 30. f. $6 a-8 a$.

1. P. palustris, t. 54. f. 4, t. 127. f. 6, t. 267. f. 2 ; Adams, Gen. Moll. t. 30. f. 8.

2. P. sulcatus, t. 52. f. 1 .

Fig. 55-Teeth of Pyrazus striatus.

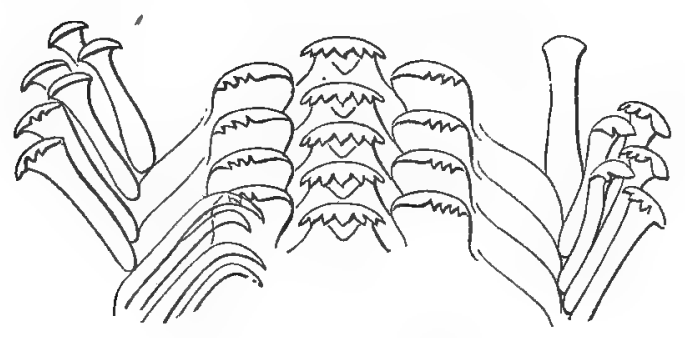

+ Canal produced.

7. Lampania.

Shell turrited; whorls waved; aperture ovate, nicked in front; inner lip thick; outer dilated, sinuous. Operculum circular, of many whorls.-Adams, Gen. Moll. t. 30. f. $5 a$.

1. L. zonalis.

Mangrove swamps.

\section{Potamides.}

Shell turrited ; whorls angulated ; mouth ovate, produced in front; outer lip thin, sinuated in the middle.

1. P. ebeninus, t. 52. f. 4 ; Adams, Gen. Moll. t. 30. f. 6.

\section{++ Canal indistinct, like a groove.}

\section{Cerithidea.}

Shell turrited; whorls flattish, waved and striated, subangular in front; mouth round; canal indistinct; outer lip dilated. Operculum circular.-Adams, Gen. Moll. t. 31. f. 2 a.

1. C. obtusa, t. 52. f. 2 , t. 127 a. f. 10 , t. 267 . f. 3 .

2. C. Kieneri, t. 267 . f. 4.

3. C. Carbonnieri, Adams, Gen. Moll. t. 31. f. 2.

Teeth of Cerithidea? obtusa $3 \cdot 1 \cdot 3$; central and inner lateral similar, with transverse, reflexed, subdentated apex; the inner lateral (central?) with elongated linear roots, oblique towards the 
centre; outer lateral elongate, with similar reflexed end; the end of the inner of the two denticulated. Most like Viviparus (fig. 56).

Fig. 56.-Teeth of Cerithidia.

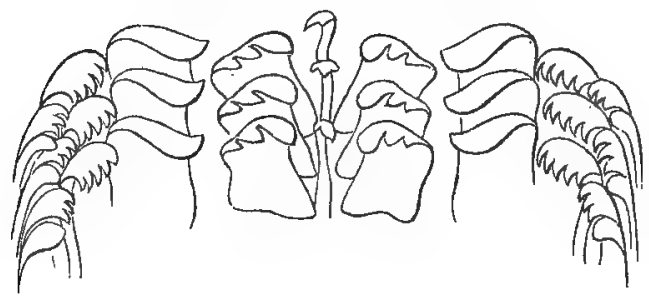

The Cerithidea are found generally in brackish water in mangruves, swamps, and the mouths of rivers. Sometimes they crawl on the leaves and stones in the neighbourhood, and sometimes they are found suspended by glutinous threads to boughs and the roots of the mangroves. Foot broad, suborbicular, expanded. Trunk elongate, subcylindrical, annulated. Tentacles short, with the eyes at the tips. Soc.

Rissoce are found similarly suspended.-See Gray, Proc. Zool.

**** Triphorina. Operculum circular, many-whorled. Shell turrited, sinistral. Mouth roundish, with a posterior tubular canal; anterior canal tubular. Tentacles united by a erested veil.

\section{Triphoris.}

Shell turrited. Operculum circular.

1. T. perversus, t. 53. f. 2 ; Adams, Gen. Moll. t. 30. f. 4.

Animal of Triphoris adversus slender. Head broad, short. Tentacula long, cylindrical, slender; apex subclavate, far apart at the base, connate by a sinuous veil. Eyes on very short tubercles at the base of the tentacula. Proboscis recondent? Chin distinct, rather free in front, vibrating. Operculigerous lobe simple. Siphon short. Operculum few-whorled, with a nearly central nucleus.Lovèn, Ind. Moll. Scand. 21.

Triphoris perversus does not form varices in the shell.-Philippi, 195.

The number of granular striæ increase with age in Triphoris perversus of the Mediterranean. The young has only two series of granules; when more advanced in age, a third, intermediate in position and smaller, is added; and in the full-grown shell the last whorl has four distinct series.-Hinds, Ann. \&Mag. N. H. xi. 17, 1842. 


\section{Fam. XVII. TURRITELLAD无.}

Muzzle short, contractile (not retractile), depressed, papillose on the edge; mouth inferior. Eye-pedicels fixed to the base of the tentacles. Lingual membrane minute, linear. Teeth $3 \cdot 1 \cdot 3$; central single, hooked, denticulated; inner lateral, first broader, recurved and serrulated above; two outer lateral similar, ligulate, angularly bent, serrulated on each side above.

Teeth $3 \cdot 1 \cdot 3$. Tentacles subulate. Eyes basal, external. Mantle fringed on the edge, slightly siphoned in front. Gill single, very long. Foot short, truncate; opercular mantle simple. Operculum horny, circular, spiral; whorls many, fringed on the edge. Shell turrited, imperforate, of many whorls; aperture subquadrate ; outer lip often rather produced.

Marine.

\section{$\S$ Mouth of shell subquadrate, simple in front.}

\section{Turritella.}

Shell turrited; whorls convex; mouth subquadrate; outer lip simple; mantle edge bearded; nape not crested. Operculum circular; edge of whorls striated, fringed.-Adams, Gen. Moll. t. 38. f. $1 a, b$.

1. T. communis, t. 53. f. 7 ; Forbes \& Hanley, B. M. t. J.J. f. 4 ; Adams, Gen. Moll. t. 38. f. 1.

2. T. triplicata, t. 128. f. 6 .

.3. T.? rosea, t. $53 . \mathrm{f}$. 1 .

Mantle of Turritella communis loose, ornamented at the upper part with a fringe of seven long and seven shorter strands, the longer ones foliaceous, fimbriated on both edges. Head: a small flat rounded muzzle resting on the foot like $\nabla$ ermetus. Tentacula elongate, subulate; eyes at the external tumid base. Foot very short in front and behind, truncate and scarcely auricled in front. Mouth with two horny plates and a short tongue. Branchial plume single, of long pectinations, which have connection with the fringe of the head; above them is a range of coarse strands, like the mucous fillets of Buccinum. On the back of the head and neck are two raised white sinuous longitudinal lines, running parallel to the branchial cavity. Operculum horny. They live in tenacious mud, mixed with shelly debris. I believe they live buried and fixed, and can only protrude the head and tentacula from the mass. They-have only a very slow progression, occasioned by the shortness of the foot.-Clark, Moll. $333 \& 518$.

Head of Turritella terebra, Mont., small, broad ; muzzle depressed, rather oval, papillose on the edge. Eye-bearers short, rather tumid. Tentacles slender. Foot short, strong, dilated in front, wedgeshaped, slit, shortened behind; operculigerous lobe simple. The right canal furuished with a lobe. Margin of the mantle formed with a reflexed pinnated fringe in three series. Operculum with a spiny edge.-Lovèn. 
"Subtentaculo Turritella triplicata dextro lobus oblongus, lobus lateralem Trochorum referens, alter lobus similis magis postice et inferius situs est. In cervice lobus transversus conspicitur margine crispato. Pallii margo fimbriatus, lobis latis incisis; in pagina interna cirri brevissimi tres adsunt. Affinitas magna cum Cerithiis in propatulo est." - Phil. Sicil. ii. 160. Very different from the descriptions of the animal of Turritella terebra, Philippi, Moll. Sicil. i. 191.

Fig. 57.-Teeth of Turritella ungulina.

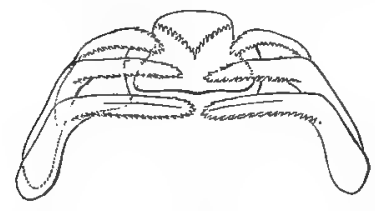

Central tooth of Turritella ungulina subquadrate, wider at the base, cutting edge triangular, denticulated; first lateral tooth with the tip recurved, serrulated on both sides; second and third similar, angularly hooked, strap-shaped, serrulated on both sides (fig. 57).

The animal of Turritella alternata, like Melania virginica, and in common with many freshwater shells, has the power of gliding along the surface of the sea with the shell downwards. The rostrum about one-third the length of the tentacula. Tentacles filiform, cylindrical, obtuse at the tip, nearly as long as the foot, white, brown ringed. Eyes not prominent, at the outer base of the teutacles. Foot longer than the aperture of the shell, rather acute behind, truncate a little convexly in front. The shell when taken from the water becomes cinereous white. Operculum horny, blackish.-Say.

\section{Zaria.}

Shell turrited, spixally ribbed; mouth ovate, subquadrate; outer lip simple.

1. Z. duplicata. Turritella d., Kiener, t. 128. f. 7 ; Adams, Gen. Moll. t. 38 . f. 3 .

\section{Torcula.}

Shell turrited; whorls subangular in front, with a deep sunken central groove; mouth subquadrate; outer lip with a deep roundish central sinus. Operculum - ? Animal —?

1. T. exoleta, Adams, Gen. Moll. t. 38. f. 2 (shell only).

\$ Mouth nearly circular, simple in front.

4. Eglisia.

Shell turrited, spirally ribbed; whorls rounded, with a deep sutural groove; mouth roundish; outer lip simple.

1. E. spirata, Adams, Gen. Moll. t. 38. f. 5 (shell only). 
\$§ Mouth of shell ovate, with an indistinct canal in front.

\section{Mesalia.}

Shell turrited, spirally ribbed; whorls convex ; mouth ovate, subcircular, with an indistinet canal in front; outer lip simple. Operculum circular; whorls many.-Adams, Gen. Moll. t. 38. f. 4 a.

1. M. brevialis, Adams, Gen. Moll. t. 38. f. 4 (shell only).

$$
\text { ** Operculum annular (p. 95). }
$$

\section{Fam. XVIII. BARLEEIAD正.}

Animal : Eyes exterior, basal. Tentacles short, broad, rounded at the tip, not setaceous. Rostrum simple. Foot nicked behind; opercular lobe simple, like Rissoella. "Operculum testaceous, subannular ; under surface with a raised rib and a long pointed testaceous apophysis proceeding from the nucleus," nearer the base than the centre. Shell conical, turbinate; whorls tumid, smooth or striated; aperture oval, entire, contracted behind, rounded in front ; outer lip acute, simple. Teeth —?

\section{Barleeta.}

Shell oval; whorls tumid, rapidly increasing; aperture oval, entire; outer margin sharp. Mantle enclosed, simple, without posterior filament. Rostrum very short. Mouth vertical. Jaws horny. Tongue spinose. Tentacles very short, broad, cylindrical ; eyes very large, black, on the outer side of the base. Foot elongate, narrow, oval, arched and double-tipped in front, rounded behind; operculigerous lobe small, expanded below. Operculum testaceous, suboval, subannular, with a central longitudinal furrow and a testaceous central apophysis.

1. B. rubra, Forbes \& Hanley, B. M. iii. t. 78. f. 4, 5, t. 80 . f. 3.

\section{HYDROCANA.}

Shell conical ; aperture roundish. Peristome simple, thin. Operculum oblong, subspiral, of half a whorl. Nucleus subapical, with a prominent process on the straight inner edge. Tentacles very short, conic, broad, close together over the base of the subcylindrical rostrum. Eyes on the middle of the upper part of the base of the tentacles.

1. H. Callaroensis, Pfeiffer, Küster Conch. t. 13. f. 28, 35. On stones in Dalmatia.

\section{Fam. XIX. VIVIPARID压.}

Trunk annulated, contractile. Teeth few, unequal; central 1, 
lateral $3 \cdot 3$, converging. Eyes sessile, or on very short tubercles on the outer side of the base of the tentacles. Tentacles subulate. Neck with a small lobe on each side. Male organ at the base of the right tentacle. Gill formed of three ranges of filaments. Mantle simple in front. Shell free, spiral, ovate, covered with a thin, transparent, or thick, hard, olive, polished periostraca; aperture ovate. Peristome continuous. Operculum annular.

Fluviatile.

The family has much the external appearance of the Apple-snails (Ampullariala), also river shells chiefly found in warm climates, and which likewise have an annular operculum; but these have pedicelled eyes, very long tentacles, and a long appendage to the forehead.

\section{\$ Operculum horny, thin.}

\section{Viviparus.}

Shell ovate, thin, banded. Periostraca thin, with hairy bands. Peristome thin. Operculum horny, nucleus near the middle of inner side.-Adams, Gen. Moll. t. 36. f. $1 a$.

1. V. vulgaris, t. 124. f. 3 ?, 6, 9; Forbes $\&$ Hanley, B. M.t. H.H. f. 2 .

2. V. bengalensis, t. 124. f. 2 .

3. V. ampullariformis, t. 127 a. f. 5.

4. V. decisus, t. 310. f. 10.

5. V. fasciatus, Adams, Gen. Moll. t. 36. f. 1.

The lingual band of Viviparus strong, slender, elongate. Teeth $3 \cdot 1 \cdot 3$ (fig. 58), laminal, longitudinal, subovate, apex recurved;

Fig. 58.-Teeth of Viviparus vulgaris.

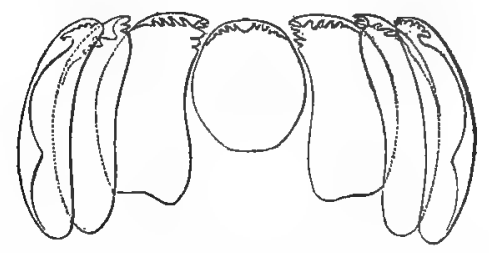

middle lobed, obtusely toothed on each side; lateral nearly similar, laminaceous, slightly curved; apical edged, denticulately lobed on each side; the inner shorter and broader, the outer winged on the outer edge.-Loven.

The gills of Paludina are formed of a series of triangular plates attached to and forming an oblique line down the left side of the branchial cavity. There is a similar ridge in the cavity to that in Ampullaria, but the ridge up the back of the neck runs more to the left, and there is a fat mass between it and the right side of the body. 
There is an appendage on each side of the head, arising from the back of the tentacles; that on the left side is small, on the right larger before; the hind portion forms a canal as in Ampullaria. The muscle of attachment is double, the left portion the smallest. Tentacles conical, with the eyes nearly at the base.

The American and European species are viviparous; the young are covered with spiral bands of hairs, varying in number in the kinds. There are only five lines in $\bar{V}$. fasciatus, and many close lines in $V$. achatina.

The Vivipari are sluggish, feeding upon living and decayed vegetable matter, preferring nearly stagnant waters or very sluggish rivers with a bottom of soft mud; the extension of the foot in front prevents them from taking food except when at rest. They are rarely found reversed; a reversed specimen of $V$. decisus was named $\vec{V}$. heterostropha by Kirtland.

The animal of Viviparus decisus of North America is yellow or bluish, with numerous orange spots on the head, tentacles and foot. Tentacles black-tipped; under side of the foot with light lines radiating from the centre to the edge. They live in ponds and muddy streams, usually concealed under the shelving banks or imbedded an inch or two among loose mud and roots. The apex of the shell is generally eroded; the young are excluded in a living state with three whorls to the shell.

Vivipamus ponderosus, which Deshayes considers an Ampullaria, and Say a Melania, has the true lorny operculum and the viviparous habit of Viviparus.

Lamarck, in his first work, confounded the Vivipari with the genus Cyclostoma, and Draparnaud has placed in his genus some marine species belonging to Littorina. Cuvier, overlooking the

Fig. 59.-Viviparus vulguris. Eggs with young and gills seen through the shell.

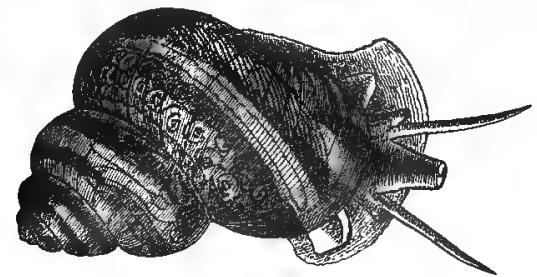

character of the operculum and some other peculiarities in the animal, confounds them with the animal of Littorina.

Férussac, overlooking the structure of the operculum of Vivipari and the number of series of gills, observes, "We are obliged to reunite the genera Paludina and Melania of Lamarck; their animals are perfectly similar, and their shells often so analogaus, that one is embarrassed to know which genus to refer them to.' We put with them also the genus Rissoa, which is operculated, but we do not know its animal."-Tabl. Syst. Moll. ii. xi. 


\section{Rivulina.}

Shell ovate, conical, smooth; upper whorls dotted or lined with brown. Peritreme continuous, with a slight depression behind the columella in place of an umbilicus. "Operculum like Paludina."

1. R. modicella, Lea, P.Z.S. 1850, 197.

2. R. zeylanica.

\section{Paludomus.}

Shell ovate, conical, solid, smooth, with granulated ribs. Operculum horny, annular; nucleus subcentral, near the front or inner edge.-Adams, Gen. Moll. t. 36. f. $2 a$.

In ponds and slow rivers.

1. P. conicus, Gray, P.Z.S. 1849.

2. P. ? spurcus, t. 127 a. f. 4 , edge of mantle festooned. Is it a Melania?

\section{Tinalia.}

Shell semiglobose, costate, nodulose. Mouth very large, ovate. Operculum horny, annular ; nucleus marginal, near the front of the outer edge.-Adams, Gen. Moll. t. 36. f. 3. Mountain streams.

1. T. aculeata.

\section{$\$$ Operculum horny, with an internal shelly coat. Oviparous.}

\section{Bithinia.}

Shell ovate, thin, with a thin periostraca; whorls convex. Peristome thickened internally, Operculum with a shelly internal coat; nucleus subcentral.

1. B. tentaculata, t. 124. f. 8; Forbes \& Hanley, B. M. t. H. H. f. 3 ; Adums, Gen. Moll. t. 36. f. 4.

2. B. viridis, t. 124. f. 7 .

3. B. Leachii, Forbes \& Hanley, B.M. t. H.H. f. 4.

4. $B$. sulcata $=$ Valvata sulcata .

M. Moquin-Tandon observes, Bithinia differs from Paludina thus : The head is narrow and does not exceed the plane of the foot; it has no jaws ; the eyes are perfectly sessile, rather behind the base of the tentacles; the tentacles are always equal; the gills are formed of folds placed in one series; the stomach is furnished with cartilaginous stylets; the male organ is bifid, always exterior, and situated behind and on the outside of the right tentacles, and it is destitute of the large glandular pouch which yields the red colour of the Paludince.-Petit, Journ. Conch. 1851, 245.

In Bithinia the gills consist of only a single series of transverse parallel flexuous folds attached to the surface of the branchial cavity, which are never visible externally ; the fold narrows at the two ends of the apparatus; the penis is placed on the base of the right tentacle, as in Paludina. 
The Bithinice are oviparous, their eggs being deposited in oblong groups, like the Lymnei or pond-snails, on the stems and leaves of freshwater plants.

d. Aills laminar, forming an oblique line across the mantle-cavity; lamina elongate, linear. Lingual band elongate, winged at the sides in front. Shell free, subspiral; mouth large, expanded; of young regularly spiral. Animal sedentary, rarely changing its place (pp. 78, 86, 95).

$$
\text { * Operculum none. }
$$

Fam. XX. CALYPTREADÆ.

Shell subspiral, depressed or subconic. The front of the body produced, depressed, rather dilated on the sides. Rostrum short, scarcely produced, depressed. Mouth erect, small, terminal. Tentacles subulate, short, at the base of the rostrum. Gills of rather short filaments. Foot small, expanded, well separated from the mantle. Lingual membrane elongate, winged on each side in front, the wings being united beneath. Teeth $3 \cdot 1 \cdot 3$; the central simple, recurved, toothed at the tip; the inner lateral broad, with a triangular toothed tip; the outer claw-like; the second lateral minutely toothed at the end.

The eggs are enclosed in a thin membranous bag in small groups under the foot of the animal. The shell in the egg is subglobular, of one or two gradually enlarging whorls, which rapidly enlarge as soon as the animal is hatched.

a. Crepidulina. Foot naked. Shell subspiral. Body and shell. depressed horizontally; apex of the shell sublateral, subposterior; inner plates of the shell horizontal.

\section{Crepidula.}

Shell obloug, convex; inner lip transverse, concave beneath.

1. C. costata, Fig. Moll. t. 58*. f. 2 .

2. C. maculata, t. $58^{*}$. f. 4 .

3. C. aculeata, Adams, Gen. Moll. t. 40 . f. 7, t. 58*. f. 5.

4. C. patagonica, t. 58*. f. 6 .

5. C. Adolphæi, t. 130. f. 4 (animal in shell the wrong way).

Central tooth of Crepidula unguiformis compressed ; cutting edge

Fig. 60.-Teeth of Crepidula unguiformis.

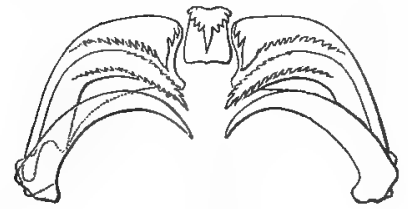

produced, triangular, with one sharp point, serrated on both sides; 
lateral teeth, first produced on the outside, the tip sharp-pointed and serrated on both sides, second and third somewhat similar, claw-like, the former more curved, the latter simple.

The foot of Crepidula is oblong, nearly the size and form of the concavity of the under side of the shell to the edge of the inmer lip; the rest of the chamber is occupied by the dilated head, which is rather expanded on the sides. The tentacles are linear, with the eyes on small tubercles on the outer side of the base, and the forehead is notched.

The species of these attached shells are very difficult to distinguish, from the various forms thev assume under different external circumstances. From the fact of each species assuming, under the same circumstances, a peculiar form, it has been thought that they must all be varieties of the same species; but I am inclined to think that most probably the species of each distinct locality are different, though each perhaps offering the same variations: thus, the Crepidula of the Mediterranean, of Peru, and the east coast of North America, though they may each present the four common varieties, may be four distinct species, the geographic character being perhaps the best distinctive mark.

In Sicily, Crepidula fornicata is always fixed on the outside and c. unguiformis on the inside of shells; the former is streaked with brown, and generally covered with $V$ ermeti, Flustrc, and other parasites; sometimes the edge of the shell is sinuous, from the irregular form of the body on which it was living, and hence called $C$. sinuosa by Turton. These characters have been used to distinguish the species, instead of proving they are only one, in different situations.

Crepidula fornicata, which is convex and coloured, M. Philippi (Moll. Sicil. i. 126) observes, in Sicily is always on the outer surface of the shell, while $C$. unguiformis, which is flat, white and smooth, is always attached to the internal surface of the shell; having collected 116 specimens in that situation, he gives this difference of habitat as a proof of their being distinct species, while I am inclined to regard it as a proof that the difference in the forms and colour depend on the part of the shell to which they happen to be attached.

Many of these flat, white specimens of Crepidula unguiformis have near the tip a more convex part, showing the form of the shell in its younger state, and this part is often streaked with brown like the convex variety. These specimens, combining the two varieties in the same individual, also prove that these animals sometimes do not take up the habitation on the inside of the shell, until they attain a certain size, as when they do so they suddenly change the form and colour of their shells.

On the other hand, Mr. Stimpson states that Crepidula fornicata sometimes occurs with $C$. unguiformis in the apertures of univalves, where it preserves its colour, convexity and other characters. - Shells of New Eng. 30. [I have never seen them in that situation.]

Crepidula fornicata varies in shape according to the body on which it rests; four or five different ages are frequently found riding upon each other. When growing on Pecten concentricus, it is found 
to have ribs corresponding to those of the Pecten. When found in the cavities of shells, it is white, flat, with a convex diaphragm; the younger specimens are rounded, but generally become elongated by age ; and it is otherwise very variable in shape, conforming itself to the position it occupies in the throat of the shell. When found among stones at the roots of sea-weed, it is generally of a small size, with a convex diaphragm.

Crepidula dilatata changes its form and character according to the body to which it happens to be fixed:-

1. If attached to a broad stone or other body, the shell is smooth, circular or ovate and moderately convex; it is then $C$. dilatata, C. peruviana, C. depressa, C. patula, C. lineolata, C. Adolphai, C. chilensis, and C. strigata.

2. On the contrary, if fixed to a small round stone, and the shells are obliged to group themselves on one another, it is then narrow, very convex, and $C$. nautiloides.

3. When the young shell happens to be in deeper water, and fixes itself between the roots of sea plants, it becomes irregular, thick, and of a uniform colour; it is then C. pallida.

4. If it happens to be fixed on the inside of a dead spiral shell, especially if that shell is inhabited by a Soldier crab, it becomes flat or even concave externally, and is of a white colour; it is then $C$. plana or C. unguiformis.

Crepidula patagonica and $C$. aculeata occur attached to stones on the coast of South America; the former often chooses situations much beaten by the waves.

Crepidula dilatata forms large rounded massive groups, the lower shell being attached to a stone or shell, and the others all placed on the back of it.

\section{Garnotia.}

Shell oval, convex, covered with a smooth periostraca; apex medial, posterior, distant from the base; inner lip deep within the cavity, shelving downwards in front.

1. G. solida, Hinds, Voy. Sulph. 53. t. 14. f. 7, 8. G. rostriformis, Gould, Exped. Shell, 14.

Living attached to the outside of shells.

b. Galerina. Foot naked. Shell subspiral. Body and shell conic, subspiral; apex of the shell superior, subcentral; inner plate of the shell subspiral, ascending obliquely.

\section{Galerus.}

Shell subconic; inner lip subspiral, oblique.

1. G. chinensis, t. 130. f. 1; Forbes \& Hanley, B. M.t. B.B. f. 8-13. (young shell spiral, f. 10,11); Adams, Gen. Moll.t. 40.f.6.

Central tooth of Galerus sinensis wider at the base; cutting edge triangular, serrated. Lateral teeth : first with the tip wide and 
serrated; second and third somewhat similar, claw-like, the former serrulate on the outside.

Galerus sinensis lays its spawn on stones and old shells. The spawn is enveloped in bundles of fimbriated, colourless membrane,

Fig. 61.-Teeth of Galerus sinensis.

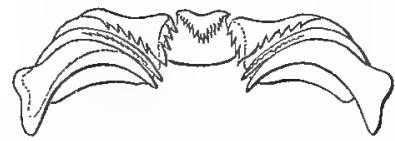

the edges of which appear white or yellow owing to the included germs (eggs). The fry have a helicoid shell, rather large eyes on the base of short, triangular tentacles, and large, ciliated necklobes.-Brit. Moll. 465 .

The shells of the young animal (which may be seen on the apex of the adult specimen) are spiral, with gradually enlarging whorls like a small Capulus.

Galerus chinensis varies in colour from white, hyaline, yellow, to reddish or dull violet; also in being more or less elevated, the crown more or less spiral, and the surface smooth or covered with small, arched, elevated scales; sometimes one side is smooth and the other very rough, or the middle smooth and the periphery scaly, or the centre scaly and the circumference smooth. The same variations occur in the species found in other seas.

Galerus sinensis, which was kept in confinement, swallowed a Goniodoris nodosa preserved in the same vessel.-Brit. Moll. 465.

\section{Trochita.}

Shell conical, spiral; whorls three or more; inner lip concave.

1. T. radians, t. 58*. f. 3 .

2. T. pileus, t. $58^{*}$. f. 1 .

3. T. occidentalis, n. s., t. 130. f. 2 ; Adams, Gen. Moll. t. 40. f. 5.

Trochita trochiformis: living attached to rocks or large detached stones on the coasts of Chili and Peru. They attach themselves very firmly, and do not change their place, covering their eggs which are enclosed under the shell. The animal is uniform pale yellow; the foot oblong, transverse, as if two-lobed in the middle in front; the tentacles long, with the eyes on the lower third of their length.

\section{Crucibulum.}

Shell subconic; inner lip very short, leaving a cup-shaped central cavity.

+ Internal cup small, at the end of a distinct shelly plate, showing it is the cavity in the axis, like the umbilicus in other. shells.

1. C. undulatum. 
H Internal cup large, nearly sessile, on the side of the cavity of the shell.

2. C. lignarium, t. 130. f. 2 ; ddams, Gen. Moll. t. 40. f. 4.

The Crucibula, like the Crepidula, are often grouped together, forming large masses, and one shell attached to the back of the other. They also assume the character of the surface of the shell to which they are attached; those on Pectens, \&c. being rayed.

In all the varieties of Crucibulum rugosum the foot is circular, becoming thicker as the shell is higher, yellowish above, spotted with black on the sides; the cephalic mass oblong, transverse, distinct. Tentacles elongate, acute, with the eyes in their middle. The buccal appendices separated into two very blunt, as if truncated lobes.

The place where the animal of Crucibutum imbricatum is fixed is often a little eroded.

The body of Crucibutum lignarium has a small roundish form, and is only slightly larger than the cup-like internal cavity of the shell ; the rest of the cavity of the shell within the mantle being occupied with the large head of the animal, which is oblong, transverse, and rounded on the sides behind the subulate tentacles, which have the eyes placed on their outer side rather above the base, and the forehead is divided into two truncated rounded lobes.

c. Calyptraina. Foot forming a shelly inferior plate. Shell conic, with a folded process under the apen.

\section{Calyptra.}

1. C. equestris, Owen, Trans. Zool. Soe.; Adams, Gen. Moll. t. 40. f. 3 (shell and base).

\section{Fam. XXI. CAPULID无.}

Shell conical, cup-shaped. Apex subspiral, small. Posterior cavity simple. The front of the body scarcely produced. The rostrum elongate, depressed, annulated. Lips produced into a long, hamate canal. Tentacles elongate, subulate, at the base of the rostrum, united by a short band continued over the base. Gill composed of elongated, slender filaments. Foot folded on itself, and often secreting a shelly plate or forming a cavity in the body to which it is attached. Egg-cases membranaceous, attached in a tuft on the front of the foot.

\section{* Foot simple or secreting a shelly plate.}

\section{Capulus.}

The foot naked, without any under shell.

1. C. ungaricus, t. 268. f. 12 ; Forbes \& Hanley, B. M. t. C.C. f. 5. 
Central tooth of Capulus ungaricus transverse, depressed; cutting

Fig. 62.-Teeth of Capulus ungaricus.

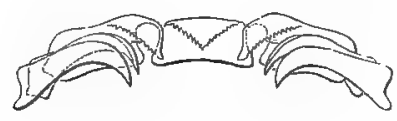

edge broadly triangular, minutely toothed; first lateral tooth drooping, serrulated; second and third somewhat similar, claw-like.

Capulus ungaricus carries its egg-cases in groups, until they are hatched, under the neck in front of the foot.

The branchial apparatus of Capulus ungaricus consists of a heart and one auricle, and a series of long, pale brown filaments, which spring from the base of the walls of the cervical cavity, and do not present a compact, plumose leaf. The foot is tough, coriaceous and circular, with an anterior puckered ruff or upper skin, or sort of mentum.-Clark, Moll. 265.

Prof. Forbes described the foot as broad, expanded, truncate in front and tapering behind.

The foot of Capulus is described as puckered in front, but the 'puckering' appears to be what is usually called the sole of the foot in other Gasteropods, contracted into that form. A somewhat similar modification of the foot is found in the genus Vermetus, where there is no appearance of any flat sole to the foot, but the end of the foot, which usually bears the operculum, is contracted, subcylindrical, truncated at the end, and closes the mouth of the cylindrical shelly tube; and in front, under the head, are two subulate processes which have been called tentacula, but which appear to be the lobes which are often found at the front end of the foot produced into this form. Some zoologists have objected to this explanation of the structure of the animal, but the discussion may be considered set at rest by the discovery of the animal of the genus Siliquaria (Phil. Moll. Sicil. t. 9. f. 24), which has nearly the same structure of the foot as the genus Vermetus; but here the foot is rather lengthened, and the front of it is marked with a short, narrow, flattened band, which is evidently the usual flat part of the foot which is found in a more expanded state in other Gasteropods.

Dr.Turton (Zool. Journ. ii. 566) remarks, "The Pileopsis ungarica may eventually be considered as a bivalve shell of the genus $H i p$ ponyx; as in removing a living specimen from an oyster, we observed a thin laminar under-valve, which is now in our cabinet. The horse-shoe-shaped muscular impressions are also exactly similar to those of the Hipponyx."

Mr. Clark thinks that the "rudimentary lamina," sometimes observed on the foot of the Capulus, "probably has its origin in a compressed mass of testaceous pulli in adherence to it."'-Moll. 263 .

In the Mediterranean they live attached to shells, zoophytes, and especially the red coral (Corallium nobile). 
Pilidium commodum of Middendorff (Reise, ii. 214.t. 17. f. 4, 11) appears to be a species of Velutina, or perhaps a subgenus allied to it, rather than belonging to this Family.

\section{Hipponyx.}

The foot secreting a testaceous valve, which is adherent by its outer surface to marine bodies.

1. H. radiata, t. 130. f. 6 .

2. H. foliata, t. 130. f. 5 .

The rostrum of Hipponyx subrufa rather elongate, depressed, brown, end transverse, lozenge-shaped. Month oblong, erect. Tentacles subulate, white, on the sides of the base of the rostrum, and with a belt continued over the upper surface of its base. Gills in a series of elongated filaments attached to the inner side of the mantle, forming an oblique line over the head.

Hipponyx barbata lives on stones and shells near low water mark, Panamá.-C. B. Adains.

Hipponyx granulata (Proc. Zool. Soc. 1853, 176. t. 20. f. 3) lives attached to the spines of a Cidaris on the west coast of Africa; it forms an oblong testaceous plate, with thickened edges, and the margin of the aperture is adapted to the semicylindrical surface of attachment. At first sight, this species has very much the appearance of a Pedicularia.-Adams.

** Foot forming a deep concavity in the surface of shells, with a horse-shoe-shaped ridge in the centre.

3. Amalthea.

1. A. conica, t. 130. f. 7.

In the young state, the shells of Amalthea conica are subspiral, of one and a half or two whorls, and transparent brown. Immediately they are hatched, they become conical and straight, and at length they thicken and the subspiral apex is worn away.

\section{Fam. XXII. VANICOROIDE.}

Shell semiovate, spiral. Mouth contracted. Muzzle produced, conical, wrinkled. Jaws two, horny, flat. Lingual membrane broad, short, "with two series of teeth, and prolonged behind." Tentacles prismate, fusiform, pointed; eyes on outer side of their base. Foot small, circular, produced in front, with a dilated membranaceous expansion on each side. Operculum horny, thin, ovate, subspiral, of very few indistinct whorls, striated. 


\section{VANICORO.}

Character of the Family.

1. V. Souleyetana, t. 128, f. 1.

2. V. cancellata, t. 103. f. 3 .

3. V. Deshayesiana, Recluz, Mag. Zool. 1845, t. 130. f. 20.

The body of $\boldsymbol{V}$. cancellata spiral. Trunk proboscis-like. Tentacles conical, simple, with the eyes on their outer bases. The foot is small, rounded, with an oblong expansion in front; a large triangular wing-like lobe on each side. The edge of the mantle is simple. The operculum very small, thin, just at the top of the foot.

Foot formed of two parts, separated by a deep cross groove ; the anterior very extensible, rounded in front and double-edged, truncated behind; the hinder portion smaller, rounded like a sucking disk, with a membranaceous expansion on each side, angularly produced in front. The operculum is placed behind and above the lateral lobes. Gills oblique, on the left side, and formed of a single series of triangular, partly free plates. Mantle edge simple, without any trace of siphon or membranaceous appendage.

e. Gills plumose, pinnate, exsertile, laminar, spiral, twisted (pp. 78, 86, 95, 115).

Fam. XXIII. VALVATIDE.

Gills plumose, exserted; laminæ pinnate, spirally twisted. Rostrum produced, short, prominent, truncated; the mouth terminal. Tentacles subulate. Operculum orbicular, spiral, of many whorls. Shell conic or discoidal. Periostraca thin, olive. Mouth round. Peristome continuous.

Fluviatile.

\section{Valvata.}

Shell conic or discoidal, umbilicated.

1. V. cristata, t. 6.f. 3, t. 126.f. 1, t. 126 a. f. 6 ; Forbes \& Hanley, B.M. t. H.H. f. 5 ; Adams, Gen.Moll.t. 36. f. 6.

2. V. planorbis, t. 126. f. 2 .

Fig. 63.-Teeth of Valvata piscinalis.

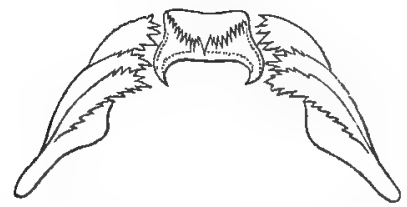

The lingual plate of Valvata piscinalis is elongate; the ceniral tooth subquadrate, base produced on both sides, incurved; cutting edge triangular, the middle cusp with a pectinated lobe on each 
side; lateral teeth somewhat similar, laminaceous, toothed on each side; the apical tooth larger than the rest (fig. 63).

Valvata piscinalis is androgynous ; the ovules very large at maturity. Penis exterior, on the side of the neck like Bithinia, but simple. Female orifice on back of neck, under mantle edge.-Moquin-Tandon, Journ. Conch. iii. 246. t. 9, f. 32.

The Valvate live in rivers. They are known from the Paludince by the whorls being more circular and not bent in any part by the proximate whorls. The gills are exserted when the animal is expanded, and are formed of an elongated tapering conical process, furnished on each side with a series of spirally-twisted laminæ placed opposite to each other. On the hinder part of the right side, near the suture of the whorls, is an exserted filiform member like a tentaculum, but rather shorter and thicker, which is called the branchial thread by Lamarck.

Valvata tricarinata is found in the small lakes of America, usually under stones, or sheltered by the deserted shell of some freshwater Unio. The shell is usually rendered somewhat opake by an earthy coating, but when removed it has a shining; pearly, emerald-green periostraca.

Valvata pupoides is very active. The head proboscidiform, half as long as the tentacles, two-lobed in front. Foot tongue-shaped, dilated into two acute angles in frout. Gills occasionally protruded to half the length of the right tentacle. Tentacles rather stout. The last whorl of the shell is nearly disjointed. They live in ponds, under stones and submerged sticks.

Mr. Lea remarks, "I observed a small apple-green globose object (the ova) passing from under the aperture of the shell. This was shortly followed by others, and soon a transparent mass became visible. This mass was passed slowly over the right side of the neck, under the pectiniform moveable branchiæ, until entirely discharged against the perpendicular sides of the vessel in which it was kept, and there the mass remained attached, the parent having abandoned it immediately."

III. Opisophthalma. Eyes sessile, on the back, between or rather behind the base of the tentacles.

A. Operculum spiral. Eyes near the base of the tentacles. Gills vascular?

Fam. XXIV. ACICULADA.

Tentacula subulate. Eyes on the head, rather behind and between the tentacula. Foot oblong. Gills vascular? Shell spiral, subturrited. Operculum horny, spiral, of few rapidly enlarging whorls. Foot divided across (allied to Truncatella and Auricula).

Terrestrial. 


\section{Acicula.}

Shell subimperforate, rather cylindrical. Peristome rather thickened, with subparallel margins joined by a thin callus. Operculum very thin, glassy, few-whorled.

1. A. fusca.

\section{Geomelania.}

Shell imperforate, turrited; aperture entire, effused. Peristome simple, expanded; the margins joined, the basal produced into a more or less developed tongue-shaped appendix. Animal like Acicula (A. Adams in P.Z.S. 1849, p. 169). Operculum membranaceous, pellucid, ovate, of a few rapidly enlarging whorls.

1. G. jamaicensis, Pfeiffer.

2. G. striata, t. 123, f. 1 .

B. Operculum annular; nucleus lateral, central. Eyes far back, behind the tentacles (p. 123).

Fam. XXV. RISSOELLID $\approx$.

Rostrum nicked, lobes elongate cylindrical, nearly as long as the tentacula. Central tooth broad, crenulated; inner lateral broad, crenated; outer small, hooked. Eyes far back. Operculum halfovate, annular; nucleus near the inner straight edge, with a central internal process.-Forbes \& Hanley, B. M. t. J.J. f. 1, 2.

\section{Rissoella.}

1. R. glabra, t. 125. f. 3 .

2. R. diaphana (Jeffreysia d.), Forbes \& Hanley, B. M. t. J.J. f. 1, cop. Adams, Gen. Moll. t. 34. f. 6.

3. R. opalina (Jeffreysia o.), Forbes \& Hanley, B. M. t. M.M. f. 2.

"Muzzle of Rissoella bifid in front. Tongue with five rows of teeth, $2 \cdot 1 \cdot 2$; central broad, crenulated ; inner lateral broad, crenulated; outer small, hooked. Tentacles two, lateral, subulate. Eyes large, prominent, placed on the back a considerable distance behind the tentacles. Foot oblong, notched and bilobed in front, with a central groove, and slightly rounded behind; operculigerous lobe small and rounded, without filament or appendages. Operculum horny, thin, ovate, annular ; nucleus in the middle of the straight inner edge, with a central internal rib ending in a projecting plate set at right angles with the disk under the nucleus." - Alder. Shell conical.

Teeth of Rissoella diaphana $3 \cdot 1 \cdot 3$, in eighteen rows; central broad, rounded above; apex curved, denticulated; lateral inner slender, subulate, curved, denticulated near the tip; outer broader, compressed, curved, denticulated near the end. Prehensile collar broad, triangular, with rows of numerous teeth. Operculum like R. opalina. 
Muzzle of Rissoella opalina produced, rounded, annulate. Tentacles four, in pairs close together at the base on each side. Eyes behind the base of the tentacles, only seen through the shell, as in Eulima. Teeth $3 \cdot 1 \cdot 3$, in twenty or thirty rows; central oblong; apex crenated; lateral inner, broad, denticulated above; outer narrower, curved, denticulated at the tip.

Dr. Philippi, not knowing that Rissoella and Jeffreysia are synonymous, arranges the former in Eulimacea (Moll. Sicil. p. 195), and the latter in Paludinacea (p. 172).

\section{Macglllivrayia.}

Animal ample. Tentacula four, very long, rather broad, linear, rugose (or ciliated ?). Lingual membrane with teeth, like Jeffreysia? Mantle produced into a long siphon. Foot very large, expanded, truncated in front, without lobes, with a float. Operculum semicircular, horny, thin, of concentric layers, with faint traces of a spiral structure at the central lateral nucleus, which is on the columellar side; from it there runs a straight rib or process, continued nearly to the outer margin, and indicated externally by a depression or groove. Shell spiral, dextral, globular, thin, corneous, transparent, slightly concentrically striated, imperforate; spire not produced, with a sinistral nucleus; aperture oblong, entire, angulated below. Peristome incomplete, thin, even-edged. Floating; gregarious ; furnished with a float like Ianthina?

1. M. pelagica, Forbes, l. c. 385. t. 3. f. 8 .

Hab. East coast of Australia, off Cape Byron.

Mr. Macdonald observes, "The disk of the foot in Macgillivrayia is broad, and connected by a narrow attachment to the body just beneath the neck; it carries an operculum behind, and is cleft by a notch in front. A raphe observable in the medial line, as well as indeed the whole character of this part of the organ, seems to shadow forth the transformation of the single foot of the Gasteropod into the wing-like expansion of the Pteropod. Lingual strap with well-marked central and lateral series of teeth, and dentated labial plates. It has a vesicular float like that of Ianthina; it consists of an aggregate of vesicles, varying both in number and size. It is exceedingly delicate. The gills are fixed to the body immediately behind the head, and not appended to the mantle; they are four in number and arranged in a cruciform manner round a central point."-Proc. Roy. Soc. vii. $191,1854$.

On further examination the author considers what are here called " naked gills" as probably auxiliary organs of natation, chiefly employed for prehension.-Proc. Roy. Soc. vii. 309, 1854. 


\section{Protopoda, Gray.}

Foot rudimentary, round, truncated or club-shaped. Shell attached, irregular. Operculum spiral or none (see p. 64).

Fam. I. VERMETID $Æ$.

Foot small, folded on itself. Body and shell rather irregularly twisted, attached by the outer surface of the shell. Egg in an oblong membranaceous sac. Shell of young subspiral, rather irregular.

a. Vermetina. Mantle and shell entire. Operculum single or wanting.

1. Siphonium.

Operculum large, smooth, circular, concave ; scar central, circular, rugose.

1. V. maximum, t. 56. f. 5, t. 128. f. 2 ; Adams, Gen. Moll. t. 38. f. 7 .

2. V. Tonganum, t. 56. f. 7 .

3. V. reticulatum, t. 56. f. 2.

4. V. carinatum, t. 56 . f. 1 .

5. V.?? - n. s. t. 82 . f. 1 .

\section{Vermetus.}

Operculum large, rather concave; whorls many, thin, with a thin produced external edge; scar central, circular, with close, regular, concentric grooves.-Adams, Gen. Moll. t. 38. f. $8 a, b$.

1. V. lumbricalis, Lamk.

2. V. Hindsii. Irregularly twisted, $B . M$.

The pointed end of Vermetus lumbricalis forms a spire of eight or ten closely connected whorls, upon each of which are two sharp elevated ridges. It generally lies in a horizontal direction, and is attached by one of its sides to some foreign body. The operculum is horny, circular, with a central nucleus and concentric rings.

The animal of Vermetus radicula of North America has the mantle fringed at its margin with short filaments. The branchial plume is very large and long, situated nearly over the middle of the back. The foot is very short and broad, dilated into rounded auricles anteriorly. The muzzle is broad, not cleft; the tongue small. The tentacles are short, conical, having the eyes at their external bases. An elevated ridge runs along the back, becomes flattened into a membrane at the head, and passes round under the right tentacle, forming a kind of canal, near which is the anus. The operculum is corneous, concentric, black and hard on the inner, and lamellated on the outer surface; it is surrounded by a thin membranous flexible portion about one-fourth its diameter ; thus it is enabled to close its shell perfectly at the aperture, and yet to retreat far into the narrowed whorls. The eggs are deposited in July. The egg-cases are soft, slightly cohering, in the form of an elongated cone bent into a 
half-circle; each contains from six to eight eggs in an advanced stage of development, enclosing young animals which had already commenced forming their shell. 'The shell of the young animal, before it escapes from the egg;, appears to be helicoid and reversed, thus showing some affinity, Mr. Stimpson thinks, with Pyramidellida.-Shells of New England, 38, 1851.

\section{Sptroglyphus.}

Operculum large, circular, convex externally, black, smooth, of numerous very close-pressed whorls; scar central, circular. Shell partly sunk into the surface of the shells to which they live attached.

1. S. corrodens, $d$ Orb. $C u b a$, t. 18 . f. 1,3 .

\section{Bivonia.} f. $1 a$.

Operculum rudimentary, small (spiral).-Adams, Gen. Moll. t. 39.

1. B. glomerata, t. 58. f. 4 ; Adams, Gen. Moll. t. 39. f. 1.

2. B. triquetra, t. 58 . f. 5 .

3. B. semisurrecta, t. 58. f. 1 .

4. B. subcancellata, Philippi, t. 58. f. 3.

\section{Serpuloides.}

Operculum none. Foot truncate, radiated at the tip ; front of foot produced into tentacula.

1. S. arenaria, t. 57. f. 2, t.58.f. 6 ; Adams, Gen. Moll.t. 39.f. 2.

2. S. inoperculata, t. 57. f. 1 .

3. S. dentifera, t. 56. f. 8 .

4. S. varians, t. 128 . f. 1.

Serpuloides varians lives at the bottom of pools on the rocks near Rio, which are only replenished at the highest tides, where the water is concentrated by the evaporation of a high temperature. The animal was generally expanded and agile, and at the least movement of the water it retreated into the bottom of its shell; when wounded it emitted a deep violet liquor.

\section{Lementina.}

Operculum none. Foot truncate, circular at top.

1. L. Cuvieri, t. 57. f. 3 (probably only a badly described and figured Serpuloides arenarius).

\section{Cladopoda.}

Operculum none. Foot elongate, front end simple, hinder extremity oblong, clavate or subtruncate.

1. C. grandis, t. 56. f. 9 ; Adams, Gen. Moll. t. 39. f. 3.

2. C. elegans, t. 56 . f. 4 .

3. C. nova zealandica, Quoy, t. 56. f. 6. 
b. Siliquariana. Mantle and shell with a longitudinal slit. Operculum many-whorled.

\section{Siliquaria.}

Operculum spiral, fringed. Foot end truncate, circular.-Adams, Gen. Moll. t. 39. f. 5 a, from Philippi.

1. S. anguina, t. 58. f. 2. Tenagoda a., Adams, Gen. Moll. t. 39. f. 5.

2. S. rosea, t. 56 . f. 3 .

Shell tubular, internally glassy, irregularly twisted; apex attenuate, sometimes spiral, with a longitudinal fissure running the whole length. Body cylindrical. Foot porrect, cylindrical, truncate in front, operculated. Head behind the foot, small, rounded. Tentacula two, lateral, cylindrical, obtuse, short. Mouth vertical, small. Eyes at the outer base of the tentacles. Mantle adnate to the belly, and back to the middle of the body, free with a longitudinal slit on the right side; right lobe narrow, hinder lobe much broader. Gills on the left lobe in a simple series of rather short threads, produced to the hinder part of the body. Rectum and oviduct parallel on the right side. Retractor muscle, as in other Gasteropods, fixing the body to the shell. Hinder part of body consisting of the small green liver and very large golden oviduct. Hermaphrodite.

\section{Leptopoda.}

Foot compressed : for leaping. Gills comb-like, distinct, on left side of mantle-cavity (see p. 64).

\section{Eyes pedicelled, with a small tentacle on the side.}

Fam. I. STROMBIDA.

Muzzle elongate, produced, annulated. Eyes on the top of thick, elongated peduncles, with the tentacles on the sides. Foot compressed, rather dilated in front, tapering behind. Siphon of mantle and canal of the shell elongate, straight, or rather bent to the left. The left side of the mantle of the adult more or less expanded or lobed. Shell solid, spiral, whorls compressed. Mouth linear. Operculum annular, horny, claw-like, serrated on the outer side (fig. 63).

a. Strombina. Tentacles on middle of eye-pedicels. Operculum claw-like. Mantle and outer lip of shell produced.

* Sinus in outer lip of shell separated from the canal by a broad

\section{Strombus.}

Shell : outer lip expanded, entire.

1. S. gigas, t. 80 . f. 2 , t. 81 . f. 4 , t. 83 . f. 1 . 
2. S. Pugilis, t. 81 . f. 3 .

3. S. Auris-Dianæe, t. 2. f. 1, and fig. 64.

4. S. Canarium (var. Isabella), t. 2. f. $4 \delta^{\star}, 3 q$, t. $81 a$ f. 1.

5. S. gibberulus, t. 81 . f. 1 .

6. S. Papilio, t. 81 . f. 2.

7. S. lentiginosus, t. 81 . f. 5 .

8. S. variabilis, t. 2. f. 2 .

9. S. Luhuanus, t. 2. f. 6 .

10. S. plicatus, t. 2. f. 5 .

11. S. vittatus, t. $84 a$. f. 5 ; Gen. Moll. t. 27. f. 1.

The foot of the Strombus is more or less rounded beneath, so that it can be of very little use for the animal to walk upon. There is a

Fig. 64.-Strombus Auris-Diance.

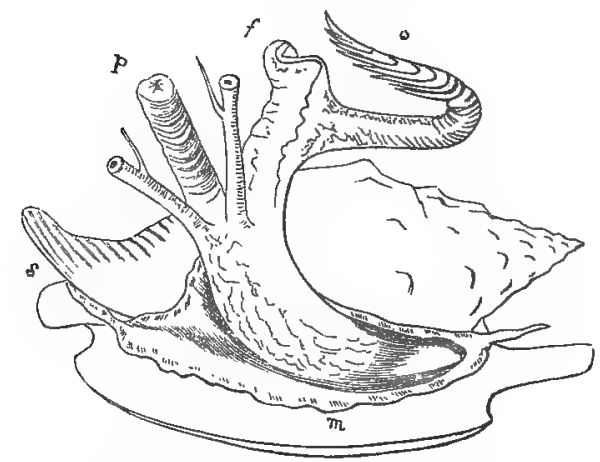

$\begin{aligned} p \text {, proboscis between eye-pedicels. } & f \text {, foot. } \\ m \text {, mantle edge. } & r \text {, siphon. }\end{aligned}$

groove in the females on the right side of the body, which is continued across the front edge of the foot. The crystalline lens of the eye is large, perfectly globular and horn-coloured, and easily extracted by pressing the end of the pedicel of the eye; the iris is well-marked and differently coloured in the different kinds of Strombs. The operculum is free for the greater part of its length, claw-shaped, and only marked with a small scar (fig. 65).

The young shells of Strombus yigas have the Fig. 65.--Operculum upper part of the cavity of the upper whorls nearly filled with a calcareous deposit of a rosy tint, and the same kind of deposit fills up the hinder angle of the cavity of the lower whorls.

Central tooth of Strombus foridus wider above, convex; cutting edge wide, with seven sharp points ; first lateral tooth with the upper margin convex, reflex, three-toothed; second and third of Strombus. similar, claw-like, simple, at the tips decussated with the opposite. 


\section{Pterocera.}

Shell : outer lip produced into tubular spines which sheath the lobes produced on the edge of the mantle when the animal arrives at adult age; in old specimens these lobes are retracted, and the sheaths then become solid spines.

1. P. truncata, t. 70. f. 5, t. 79 .

2. P. Lambis, t. 1. f. 2 \%, f. 1 우.

Quoy represents the teeth on the tongue of the sexes of Pterocera Lambis as different (see male, t. 49. f. 20) from those of the female (t.50.f. 8), the former having one, and the latter two lateral teeth on each side; the latter appears more correct, but he appears to have overlooked the interior lateral, and in the former the two internal lateral teeth.

** Sinus of the outer lip close and confuent with the canal.

\section{Fusus.}

Shell fusiform; outer lip dentated.

1. F. clavus, t. 80 .

2. F. subulatus, t. $84 a$. f. 6 . Gadius fusus, Adams, Gen. Moll. t. 27. f. 3 .

b. Seraphina. Tentacles, none? Operculum horny, claw-like, with three claws. Shell: outer lip simple. Shell truncated in front, without any distinct sinus or canal.

\section{Seraphys.}

Shell subcylindrical; spire conical. Mouth linear, truncated; inner lip smooth. Teeth —? Operculum three-clawed.-Adams, Gen. Moll. t. 27. f. $4 a$.

1. S. Terebellum, t. 82. f. 3, t. 84 a.f. 3 ; Adams, Gen. Moll.t. 27. f. 4 .

\section{Eyes sessile.}

\section{Fam. II. PHORID $\mathrm{A}$.}

Muzzle conical, produced. Eves sessile, on the outer side of the base of the subulate tentacles. "Foot small, dilated in front. Shell conical, depressed. Operculum large, subannular, horny (fig. 66). Teeth —?

\section{Phorus.}

Fig. 66.

Operculum triangular, annular; apex acute._- Operculum of Phorns. Adams, Gen. Moll. t. 40. f. $2 a$, $b$.

1. P. conchyliophorus.

2. P. solaroides (Xenophora s.), Adams, Gen. Moll. t. 40. f. 2 .

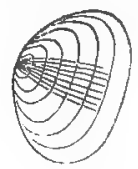




\section{Onustus.}

Shell conical, broadly umbilicated. Operculum triangular, radiately grooved; apex broadly truncated.-Adams, Gen. Moll. t. 40. f. $1 a, b ; D^{\prime} O r b$. Cuba, t. 19. f. 31 .

1. O. indicus, Adams, t. 122 a. f. 2.

2. O. javanicus, Adams, t. 122 a. f. 1 .

\section{Heteropoda.}

Foot compressed, erect, fin-like, often with a small flat disk on the hinder edge. Body and shell spiral or subspiral. Animal formed for floating, unisexual. Head distinct, with an elongate proboscis. Lingual membrane gradually wider behind, fat; central series one-toothed; lateral teeth three, flat, adpressed, transverse, bent, the first having a process attached to it, the rest simple, third shorter. Organs of generation on right side. Gills on the inner edge of the left side of the front of the mantle, not regularly comb-like, but tufted, as in Pleurobranchus (see p. 64).

\section{Fam. I. PTEROTRACHEID王.}

Body elongate, transparent, naked. Pedal fin of the males with a small posterior disk, of females simple. Gills and other vital organs in a small prominent bag, naked, or covered with a thin subspiral shell. Teeth $3 \cdot 1 \cdot 3$; lateral elongate, unequal, arched, acute. Operculum none.

\section{a. Viscera in a small elliptic sac. Shell none.}

\section{Anops.}

Tentacula none. Eyes none. Head indistinct. Shell none. 1. A. Peronii, t. 62. f. 2.

\section{Pterotrachea.}

Tentacula none. Eyes two. Body elongate, cordate behind. Tail conical, keeled. "Gills pectinate on the hinder part of the back."-Gegenbaur. Shell none.

1. P. coronata, t. 156 . f. 1 , t. 157 . f. 1, t. 158 . f. 3, t. 159. f. 1. P. aculeata, t. 158. f. 5, t. 158. f. 1, 2 (tail only). Firola Cuviera, t. 155. f. 7 , t. 160 . f. 4 . F. Peronia, t. 160. f. 8. F. gibbosa, t. 160. f. 2. F. Forskalia, t. 160.f.3. F. junior, t. 62 . f. 6, t. 156. f. 2.

2. P. Frederica, t. 157. f. 2, t. 160. f. 5.

3. P. Hippocampus, t. 155. f. 5.

4. P. mutica, t. 160 . f. 1 . P. hyalina, t. 55. f. 2.

5. P. pulmonata, t. 158, f, 4 . 
6. P. Edwardsii, t. 159. f. 2.

7. P. hyalina, t. 157 . f. 3 , var. preceding?

8. P. Lesueurii, t. 159. f. 4, var, preceding?

9. P. Keraudrenii, t. 238. f. 2.

10. P. Quoyana, t. 62 . f. 1 .

11. P. ? ? t. 87. f. 2 .

\section{Firoloida.}

Tentacles two. Body cylindrical, truncate behind. Tail very short. "Gills none."-Gegenbaur.

1. F. aculeata, t. 155 . f. 9 .

2. F. Blainvilleana, t. 155 . f. 1 .

3. F. Desmarestia, t. 155. f. 8, t. 238. f. 1 .

4. F. Eydouxii, t. 238 . f. 3 .

5. F. —?, t. 155 . f. 3 .

\section{Cerophora.}

Tentacula two, elongate. Eyes two. Shell none.

1. C. Lesueurii, t. 62 . f. 4 .

2. C. Gaimardii, t. 62 , f, 3 .

b. Shell cartilaginous, covering the viscera.

\section{Cardiapoda.}

Tentacula two. Shell cartilaginous, regularly involute.

1. C. pedunculata, t. 62 . f. 5 .

2. C. carinata, t. 62 . f. 7 .

3. C. caudina, t. 155 . f. 8 , t. 239 . f. 3 ; t. 155. f. 4 ?

4. C. placenta, t. 239 . f. 1 .

5. C. - ? , t. 156 . f. 3 .

c. Shell thin, glassy, covering the viscera.

6. Carinaria.

Tentacula two. Shell glassy, thin (fig. 67).

Fig. 67.-Carinaria Mediterranea.

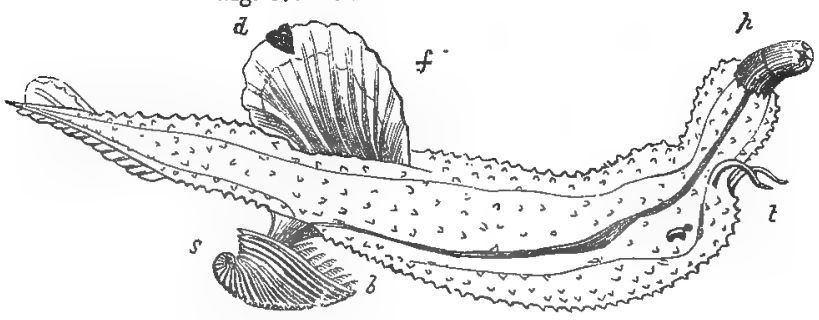

$p$, proboscis. $\quad t$, tentacula. $\quad b$, branchiæ. $\quad \forall$, shell. $\quad f$, foot. $d$, disk. 
1. C. Mediterranea, t. 63. f. 1. Pterotrachea Lophyra, t. 63. f. 3, t. 161.f. 2. C. cymbium, t. 161.f. 1. . C. vitrea, t.154. f. 2. Pterotrachea, t. 159. f. 3, without shell.

2. C. Gaudichaudi, t. 239. f. 4 .

3. C. punctata, t. 1 l. f. 3,4 .

4. C. australis, t. 62 . f. $l$.

5. C. —?, n. s., t. 239. f. 2.

Lateral tooth of Carinaria Mediterranea wide, base.on both sides

Fig. 68.-Teeth of Carinaria Mediterranea.

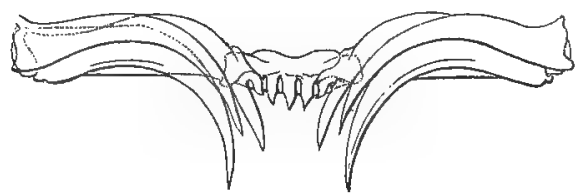

produced and winged, cutting edge three-pointed; lateral teeth nearly equal, process of the first spiniform, bent (fig. 68).

\section{Fam. II. ATLANTID五.}

Body spiral, enclosed in a shell. The pedal fin of both sexes with a small posterior disk. Tentacles two. Teeth seven-rowed, $3 \cdot 1 \cdot 3$; central lateral conical, curved, acute. Shell thin, involute, keeled. Operculum calcareous.

\section{Oxygyrus.}

Shell cartilaginous, keeled; nucleus involute, sulcated, chalky. Operculum annular.

1. O. Keraudrenii, t. 117. f. 3, operculum oblong, kidney-shaped; t. 129. f. 2 , t. 117. f. 1, operculum triangular, broad; t. $117 \mathrm{c}$. f. 3 , t. 240 . f. 2 . Ladas Keraudrenii, t. 117 c. f. 6.

2. O. Rangii, t. 240. f. $1 \& 4$, operculum roundish, trigonal.

The central tooth (Oxygyrus Rangii) rather broad, the base on

Fig. 69.-Teeth of Oxygyrus Rangii.

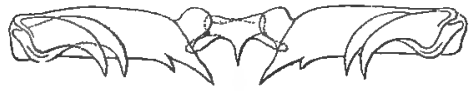

each side rather produced, the apex one-spined; the lateral teeth unequal, the first very large, broad, with an acute spine below the tip, the second and third shorter, curved, entire (fig. 69). - Lovèn. 


\section{Atranta.}

Shell shelly, transparent, keeled; nucleus spiral, smooth. Operculum spiral; last whorl very large.

1. A. Peronii, t. 117 c. f. 1 (not correct), t. 117 b. f. 5 (operculum incorrect), t. 117 b. f. 2 \& 6, t. 240. f. 6 . A. Keraudrenii, t. $117 b$. f. 4.

2. A. Lamanoni, t. 240. f. 3.

3. A. inclinata, t. 241 . f. 1 .

4. A. brunnea, t. 242 . f. 5.

5. A. inflata, t. 241 , f. 3.

6. A. Gaudichandi, t. 24l. f. 4.

7. A. Lesueurii, t. 241. f. 6.

8. A. —? (A. bossue), t. 240 . f. 5 .

9. A. depressa, t. 242, f. 4.

10. A. Quoyii, t. 242. f. 1.

11. A. rosea, t. 241 . f. 2.

12. A. helicinoidea, t. 242. f. 2.

13. A. involuta, t. 242 . f. 3.

14. A. turriculata, t. 242 . f. 6 .

15. A. ? ?, n. s., t. 117 c. f. 2,7 .

The central tooth of Atlanta Lesueurii rather broad, with an acute recurved process on each side of the base; the apex three. spined, the middle largest; the lateral teeth subequal, the first with a large process behind, armed with a short spine.--Loven.

The larva of dtlanta in the early state is oblong, with a ring of cilia round the more truncated end; then the foot and operculum and the eyes are developed on one side of the disk, and when more perfect, it has a broad fin divided into four narrow lobes in front, and two broader ones behind, broad, strongly ciliated on the edges. See Gegenbaur, Pteropoden, t. 8. f. 1-18.

\section{Steira.}

1. S. Lamanoni, Eschsch. Isis, 1825, 734. t. 5. f. 3

Most probably a badly observed Atlanta. 


\section{Order II. Scutibranchiata.}

Gills consisting of two series of lamellæ, forming one or two series over the back of the neck or under the edge of the mantle round the foot. Animal hermaphrodite, self-impregnating? Shell spiral or symmetrical, conical. Rectum often traversing the heart.

\section{SynOPSIS OF SUBORDERS.}

I. Riphidoglossa. Teeth transparent, glass-like, in numerous longitudinal series; the central $5 \cdot 1 \cdot 5$, variable in form; lateral very numerous, more slender, curved at the tip.

I. Scutibranchia. Gills in a spiral line on the left side of the gillcavity. Body, shell and operculum spiral. Eyes pedicelled.

* Sides of the foot without any fringe or tentacles. Shell not pearly. Central teeth unequal.

** Sides of the foot with a fringe furnished with beards. Shell pearly. Central teeth equal, similar.

II. Schismatobranchia. Gills in two plumes on left side of the gill-cavity, on each side of mantle-slit. Body and shell spiral. Foot fringed and bearded. Eyes pedicelled. Central teeth very unequal, large, dissimilar.

ili. Dicranobranchia. Gills in two symmetrical dorsal plumes. Body and shell not spiral. Foot slightly bearded. Eyes subsessile. Central teeth of two kinds, inner small, similar, outer large, dissimilar.

II. Heteroglossa. Teeth pellucid, in five to eight longitudinal series, variable in form, the larger ones with opake black tips. Foot without any lateral fringe. Shell symmetrical.

IV. Cirrhobranchia. Gills tufted, on back of neck. Body elongate-conical. Shell tubular, with an apical opening.

V. Cervicobranchia. Gills lamellar, in a single series on the side of the gill-cavity on the back of the neck. Shell conical, symmetrical.

VI. Cyclobranchia. Gills lamellar, on the inmer surface of the mantle, forming a more or less complete ring just beneath the margin. Shell conical, symmetrical.

VII. Polyplacophora. Gills in two lamellar series on each side of the hinder part of the under side of the mantle-edge. Shell formed of eight imbricate valves. 
I. Riphidoglossa. Teeth transparent, glass-like, in very numerous longitudinal series; central $5 \cdot 1 \cdot 5$, variable in form; lateral very numerous, subsimilar, more slender, curved at the tip, the inner ones on each side largest. Rectum traversing the heart.

\section{Suborder I. Scumibranchia.}

Gills in a spiral line on the left side of the gill-cavity. Body and shell spiral. Eyes pedicelled, at the outer side of the base of the tentacles.

A. Sides of the foot without any membranaceous fringe, with beards on its upper surface. Shell not pearly within. The second and fifth central teeth on each side large.

\section{Fam. I. NERITINID压.}

Shell bemispherical, flat beneath ; spire lateral ; inner lip flattened, transverse; outer arched. Operculum with a process on the inner side under the nucleus, forming a kind of hinge with the inner lip of the shell.

Tentacles elongate, subulate. Foot oblong. Teeth : the central $4 \cdot 1 \cdot 4$, very unequal; the outer teeth large, broad, dark; the lateral teeth very numerous, slender, hooked (fig. 70).

a. Operculum horny, with a shelly coat on each side; edge channeled (fig. 71).

\section{Nerita.}

Shell thick, hemispherical; inner lip acute, often toothed; aperture moderate or semicircular.

Fig. 70.-Teeth of Nerita peloronta.

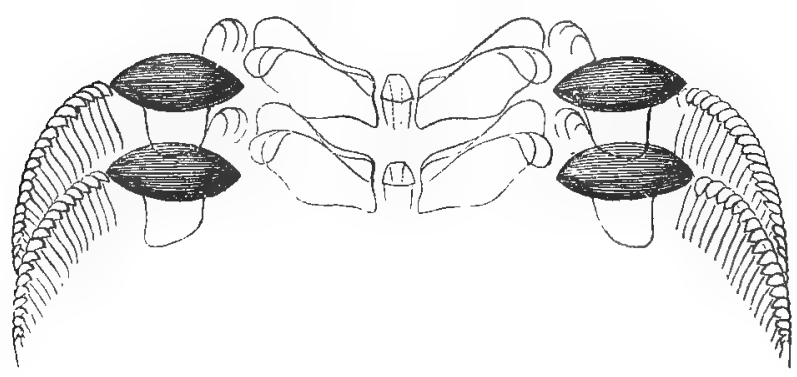


1. N. plicata, t. 45. f. 6 .

2. N. albicella, t. 45 . f. 5 .

3. N. exuvia, t. 44. f. 7.

4. N. Dunar, t. 44. f. 5,6 .

5. N. ascensionis, t. 44 . f. 4.

6. N. versicolor, t. 44 . f. 2,3 .

7. N. punctata, t. 44 . f. 1 .

8. N. polita, t. 45 . f. 8 .

9. N. lineata, t. 265 . f. 4.

Fig. 71.-Operculum of Nerita.

Nerita scabricosta lives on rocks between high water and threequarter tide-level, collected in the crevices. The young are commonly seen crawling above high-water mark where the rocks and stones are wet with the spray.-C. B. Adams.

\section{Puperita.}

Operculum shelly, with two apophyses, the anterior tubercular, the hinder subspiral, ear-shaped. Marine.

1. P. Pupa, Rossmäsler, Icon. iii. 35. f. 4, operculum.

b. Operculum solid, shelly, with a thin flexible edge.

\section{NeritelLA.}

Shell thin, hemispherical, smooth ; inner lip transverse, smooth or denticulated. Operculum as large as mouth of shell, with a simple, oblique, lanceolate, ear-shaped apophysis (fig. 72).

1. N. fluviatilis, Forbes \& Hanley, B.M. t. H.H. f. 1.

2. N. pulligera, t. 45 . f. 4.

3. N. reticulata, t. 45 . f. 1 .

4. N. brevispina, t. 45. f. 2.

5. N. communis, t. 45 . f. 3 .

6. N. strigillata, t. 45 . f. 7 .

7. N. amphibia, t. 45 . f. 9 .

8. N. virginea, t. 128 . f. 3 .

9. N. Georgiana, t. 106 a. f. 3.

10. N. Gaimardi, t. $106 a$. f. 2.

11. N. Michaudi, t. $106^{*}$. f. 1 .

12. N. picea, t. $106^{*}$. f. 4 .

13. N. vestita, t. $106 \alpha$. f. 5 .

14. N. Goldii, t. 106 a. f. 7 .

15. N. indica, t. 106 a. f. 8.

16. N. rugosa, t. $106 a$. f. 6.

17. N. tahitensis, t. $106 a$. f. 10.

18. N. Nuttallii, t. $106 a$. f. 9.

Operculum of Neritella fluviatilis with a single, oblique, lanceolate, ear-shaped apophysis.-CRossm. Icon. iii. 34, fig.

Tongue of Neritella fuviatilis with nine longitudinal series of 
teeth, with many (about sixty) series of very slender, declivated hooks; the central tooth minute, subquadrate; the first lateral large,

Fig. 73.-Teeth of Neritella fluviatilis.

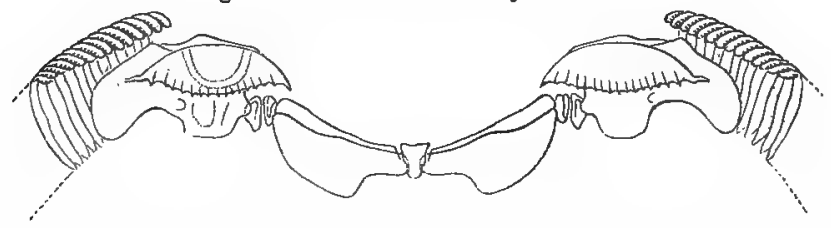

subtrigonal, scapula-shaped, with the front edge rather short, replicate; the second and third minute, between the first and fourth; the fourth very large, coloured, irregular hood-shaped, with an oddshaped base transversely produced externally into a fulcrum.-Rossm. Icon. iii. 34, fig.

Central tooth of Neritella fuviatilis minute, unarmed, body subquadrate, narrowed at the base, produced; lateral teeth three; of which

Fig. 74.-Teeth of Neritella crepidularia.

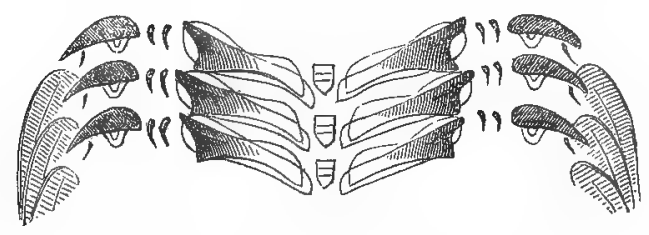

the first is very large, laminaceous, transverse, subtriangular ; upper margin rather straight, folded back, flat, the lower outwardly rounded, interiorly notehed; second and third minute, suboval, laminaceous; middle keel thicker, flexuous: lateral series of teeth about sixty; the first by far the larger, very irregular in shape, scape short, thick, furnished on the inside with a tubercle, head very large, transverse, capped, convex, anterior margin radiato-denticulated, along with the scape emitting a large wing which is rounded and recurved; other lateral teeth equal, with a suboval hook denticulated behind; scape produced on the inside (fig. 74).

Dr. Shuttleworth believes that the erosion of the apex of some of the fluviatile Neritellce is caused by the animal's filing off the apices by its teeth, the mark of the teeth being left on the surface of the erosion. This is particularly the case with the specimens which live in streams in granitic countries, and he suspects that the animals supply themselves with the calcareous matter to form their shells from this source; the body of the Neritella being withdrawn from the tip of the shell as the shell is enlarged in size.

Neritella picta is strictly marine : on sticks and stones in a grove of trees a little above half-tide level; also in dirty places on rocks at a little below half-tide level (C. B. Adams); but according to $\mathrm{Mr}$. Cuming, on a mud-bank partially overflowed with fresh water! 


\section{Catilulus.}

Shell half-ovate or oblong; apex small, subposterior; inner lip small, arched; aperture very large. Operculum small, rudimentary (fig. 75).

1. C. porcellanus, t. 46 . f. $5,6,12,34$.

"Mantle of Catillus very broad and very ex- Fig. 75.-Operculum tensible, like the Patella ; between the foot and the mantle is a keel where the gills are in the Patella. When kept in a vessel of water they come to the surface to respire. The operculum is placed on a large membrane resembling a mantle." of Catillus. -Van Hasselt, Bull. Sci. Nat. iii. 86.

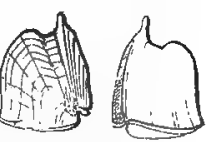

Central teeth of Catillus moderately broad; second large, trans-

Fig. 76.-Teeth of Catillus, from Ceylon.

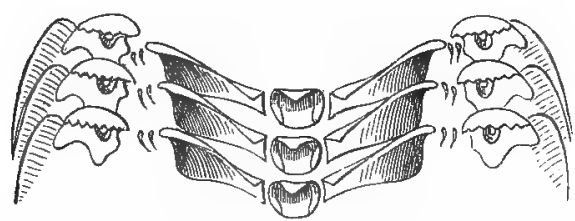

verse; third and fourth very small, conical, rudimentary; fifth oblong, with a transverse, toothed crest; lateral teeth numerous, hair-like (fig. 76).

B. Sides of the foot with a continuous fringe, with three or four elongated tentacles on its upper surface, often continued, and forming one or two lappets on the forehead between the tentacles. Shell generally pearly within. The central teeth sinall, subequal in size, often rather different in form.

* Rostrum not produced. Proboscis? retractile, surrounded by an expanded veil.

Fam. II. ROTELLADF.

Mouth small, rounded, sunken at the base of the veil. Proboscis short, cylindrical, retractile. Tongue-membrane linear-elongate. Teeth like Trochus. Tentacles linear; right free, simple, with a compressed lobe on its inner side; left tentacles with a large membranaceous expansion folded over the mouth and then back to the left side of the head, and continued by a slight ridge to the lateral fringe. Lateral fringe distinct, with three tentacles on each side, produced on the front of the right side into a large, oblong, fleshy lobe, which probably covers the base of the shell, and forms the callosity over the axis (see $A n n$. \& Mag. N.H. 1853, xii. 179). 


\section{Rotella.}

Shell orbicular, depressed, polished; porcellaneous axis callous; mouth circular, with a columnar groove.

I. R. lineolata, t. 38. f. 7,8 , t. 107. f. 6 .

Littoral, burying themselves in the sand left by the sea at low water.

Foot of Rotella lineolata truncated in front; when contracted, in spirits, with a deep central groove, and with the side edges folded down in front; lateral fringe with three tentacles on each side; the front one on the right side, near the eye, produced into an oblong fleshy lobe which partly covers the base of the shell, and probably forms the callosity. Tentacles two, subulate; right larger, free, with an oblong, compressed lobe on its hinder side, with a very indistinct indication of an eye on the inner side of the end; hence probably a modified eye-pedicel. The left tentacles smaller, partly attached to the upper side of the left eye-pedicel, which is cylindrical, with a large membranaceous expansion attached to the whole length of the side, which is fringed with small beards on the edge, and folded to the right over the mouth towards the right tentacles, and then folded back and continued by a slightly elevated ridge with the front edge of the left lateral fringe. Muzzle none. Mouth circular, sunken, under the base of the curious-shaped veil. Proboscis short, retractile. Lingual membrane elongate, with numerous setaceous teeth suddenly bent; the innermost series dilated beneath the bend and the end, and finely denticulated near the tip; denticulated hooks at the tip in oblique series on each side, without any central teeth.

According to Dr. Lovèn, the central tooth of Rotella lineolata is longitudinally subrectangular, unarmed; lateral six on each side, of which four are gradually a little longer, and are almost of the same shape as the central one; fifth and sixth elongated, keeled, the former linear, bent, the latter subfusiform; lateral series of teeth nearly equal in size, with an oval hook, in the imner ones denticulated behind at the flexure, in the middle one on all sides; scape arcuate, produced under the hook.

"Animal of Rotella opake white. Foot large, flexible, edge often playing up against the shell, with a lobe on the side of the mantle partly clinging to the shell, but not enveloping it. Mouth a curious siphon-slit next the outer lip of the shell, and filled with cilia. Tentacles four; one of these, bearing the eyes, forms an edge to the slit; the other bearing the eyes, and two other tentacles, free their whole length, the latter having roots inside the siphon. Cilia of siphon tipped with black; sometimes they gather against the sides, so that you see a tube with a black rim, but usually they are rayed.

" The Rotella live where they are left dry at least two hours each tide, just buried in the sand; when placed in water they did not move about much, only raised up their siphons, so I conclude that they feed on the minute living things brought to them by the water." -Fairbank, Ann. Lye. N. York, 1853, p. 35. 
The description of the animal by Mr. Fairbank (Ann. Lyc. New Fork, vi. 35) is not correct; and those given by Quoy and Gaimard (Voy. Astrol. cop. Fig. Moll. t. 38. f. 7, 8) and Kiener (Conch.t. 1, cop. Fig. Moll. t. 107. f. 6) are evidently from some species of Trochus.

\section{Protina.}

Shell smooth, subconical; spire depressed; axis covered with a smooth callus; columella ending in a simple point. Operculum horny. Animal —?

1. P. tæniata, Gray in Wood, Cat. Supp. t. 5. f. 12.

\section{ISANDA.}

Shell orbiculately conical, polished; whorls rounded; pillar-edge crenated; axis umbilicated. Operculum orbicular, of many whorls. Animal —?

1. I. coronata, Adams, Gen. Moll. t. 46. f. 2.

\section{Camitia.}

Shell orbicular, depressed, polished, imperforated; whorls rounded; pillar-edge callous; pillar-lip spirally twisted in front. Operculum ? ? Animal $\longrightarrow$ ?

1. C. pulcherrima, Adams, Gen. Moll. t. 46. f. 8 .

\section{Cḧ́ŕsóstomà.}

Shell subglobose, solid, polished, very slightly perforated; whorls few, rounded ; pillar-edge callous. Operculum —? Animal —? 1. C. paradoxum.

\section{** Rostrum short, produced, truncated, not retractile.}

Eyes most often free, the fringe generally above the rostrum, and continued to the sides of the foot, fimbriated, furnished with a series of little beards. Tentacles often covered with a series of papillæ. Gill-bearing lobe simple. Lingual membrane long, strong, linear, in great measure received into the visceral cavity. Teeth : central series many; lateral teeth very numerous, hooked, in a series, gradually growing more slender and more simple.

Trochina, Lovén.

\section{Fam. III. TURBINIDE.}

Operculum horny, with a solid, external, convex, calcareous coat. Frontal appendages two, between the tentacula, lobed. 
a. Turbina. Body cylindrical. Aperture of shell and operculum subcircular. Shell top-shaped; front of whorls convex.

* Operculum without spiral ridges.

\section{Sarmaticus.}

Operculum externally covered with numerous separate, flat-topped tubercles. Shell top-shaped, thick, imperforate; outer lip with a submarginal black line of animal matter.

1. S. Classicarius. Turbo Sarmaticus, Linn. Operculum thin; tubercles separate.

2. S. natalensis. Turbo n., Krauss. Operculum thick; tubercles crowded.

\section{Turbo.}

Operculum externally convex and granular (fig. 77). Shell topshaped, imperforated or perforated, covered with a periostraca; spire conical; aperture circular; outer lip simple, rather produced in front.

1. T. araucanus, t. 108. f. 3.

2. T. radiatus, t. 107 a. f. 2 .

3. T. chrysostoma, t. 41 . f. 6 .

4. T. marmoratus, t. 37 . f. 1 .

5. T. tuberculosus, t. 38. f. 5 .

6. T. smaragdus, t. 38 . f. I.

Fig. 77.-Inside of operculum of Turbo.

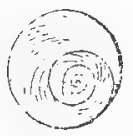

Tongue of Turbo elongate, linear, pale brown. Teeth $00 \cdot 5 \cdot 1 \cdot 5 \cdot 00$, in doubly arched series, the inner ones in a concave line, the outer

Fig. 78.-Teeth of Turbo — ? (Antarctic Expedition).

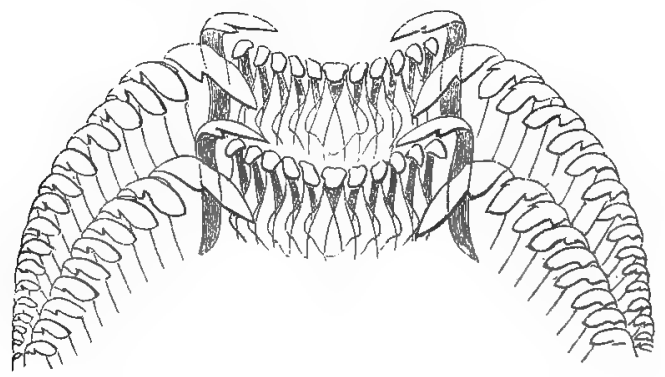

in a convex cross line; central tooth linear, dark red, rather dilated and truncated at the tip; inner lateral teeth elongate, ending in an elongated compressed hook; outer lateral teeth elongate, ending in an elongated hook, the inner one large, and gradually diminishing in size to the outer edge (fig: 78). 
** Operculum with one or more spiral ribs.

3. Marmorostoma.

Operculum with an indistinct subcentral rib, surrounded by a broad flat margin. Shell turbinate, solid, deeply perforated; spire low; aperture circular; inner lip flattened and produced in front.

1. M. undulatum, t. 38 . f. 2,3 , t. 60 . f. $9-14$.

2. M. versicolor, t. 38 . f. 4,6 .

\section{AmYXA.}

Operculum with an indistinct, broad, subcentral rib, with a narrow, flat edge. Shell top-shaped, solid, imperforate; aperture ovate; pillar-lip with a curved groove; throat grooved.

1. A. niger, t. 108. f. 1. Prisogaster n., Adams, Gen. Moll. t. 43. f. 6.

\section{Modelia.}

Operculum with a convex, subcentral granular rib, and a sharpedged submarginal keel. Shell top-shaped, imperforated, thin, granular; spire conical; aperture subcircular.

1. M. granosus. Turbo g., Martyn.

\section{Callopoma.}

Operculum with a broad central and three or five submarginal spiral ribs; outer ribs toothed. Shell top-shaped, thick, imperforate; spire conical ; aperture circular; inner lip grooved, produced in front.

1. C. fluctuosum. Turbo fl., Gray. Opercular ribs five.

2. C. saxosum. Turbo s., Gray. Opercular ribs three.

\section{Ninella.}

Operculum concave externally, and edged with two raised spiral ribs and a thin edge. Shell top-shaped, depressed, rugose, deeply umbilicated; aperture circular, with an oblong concavity near the pillar.

1. N. lamellosa. Turbo 1., Brod.

2. N. torquata, t. 39. f. 2.

\section{Coluonia.}

Operculum circular, of many gradually enlarging whorls, with a convex external rib and central pit. Shell top-shaped, solid, spirally striated, imperforate; aperture circular, contracted; inner lip rather callous.

1. C. marginata. Delphinula m, Lamk.

2. C. striata, Gray. Shell red, white-marbled, striated. Africa. 
b. Imperatorina. Body subquadrate. Aperture of shell subquadrate. Operculum oblong or ovate, solid, convex. Shell topshaped; front of whorls flattened.

\section{Uvanilua.}

Operculum flat, with two distinct convex radiating ribs, lower one straight and nearly parallel to the edge, upper arched, subcentral; axis imperforate, callous. Shell top-shaped, imperforate, with mar ginal spines.

1. U. olivaceus. Trochus o., Gray.

2. U. unguis. Trochus u., Gray.

3. U. fimbriatus, t. 38. f. 9.

\section{Calcar.}

Operculum thick, with a slight convexity over the axis; outer edge thin; axis perforated. Shell top-shaped, imperforated; whorls keeled, with spiny scales.

1. C. magnus, Chemn. Trochus Calcar, Linn.

2. C. stellaris, t. 39 . f. 4 .

\section{Pomaulax.}

Operculum flat, with three convex radiating ribs; upper submarginal; axis perforated. Shell trochiform, imperforated; whorls nodulose behind.

1. P. undosus. Trochus u., Gray.

2. P. japonicus. Trochus j., Dunker.

\section{Guildfordia.}

Operculum flat, with a very slight ridge near the arched or outer margin. Shell depressed, with elongated marginal spines ; outer lip sinuous; axis covered with a callus.

1. G. triumphans. Trochus Guildfordiæ, Gray.

2. G. heliophorus, t. 40 . f. 1 .

\section{Pachypoma.}

Operculum oblong, subquadrangular, very convex externally. Shell top-shaped, imperforated; pillar-lip rather truncated in front.

1. P. inæqualis. Trochus i., Martyn. Trochus gibberulus, Chemn.

2. P. cælatus. Trochus c., Gmelin.

\section{Liтнорома.}

Operculum ovate, thick, thicker at the end, with a broad thin margin on outer edge. Shell top-shaped, imperforated; whorls nodulose; aperture subcircular.

1. L. tuber.' Trochus t., Linn. 
15. IMPERATOR.

Operculum thin, flat, rather thinner on edge. Shell : whorls keeled, with hollow compressed spines.

1. I. solaris.

\section{6. Соокіа.}

Operculum ovate, with a slight tubercle over the axis, and a single subcentral arched rib. Shell top-shaped, rugose, imperforated, concave over the axis.

1. C. nobilis, t. 40. f. 2 .

\section{Bolma.}

Operculum ovate, suborbicular, convex, with a subcentral tubercle over the axis, and a broad submarginal spiral rib. Shell top-shaped, rugose; aperture circular.

1. B. rugosa, t. 43. f. 6 , t. 107 f. 1,5, t. 108 . f. 5 .

c. Eutropiana. Body of animal, aperture and operculum ovate.

18. Eutropia.

Shell ovate; spire conical; whorls smooth, polished; aperture oval; pillar smooth; outer lip thin, simple. Operculum ovate, externally convex, smooth.

1. E. australis, t. 41 f. 1,2 .

2. E. pulla. Phasianella p., Forbes \& Hanley, B. M. t. D.D. f. 5, frontal lobes slender.

Central tooth of Eutropia pulla transversely ovate, produced in the middle at the base; cutting part not recurved, entire; lateral teeth

Fig. 79.-Teeth of Eutropia pulla.

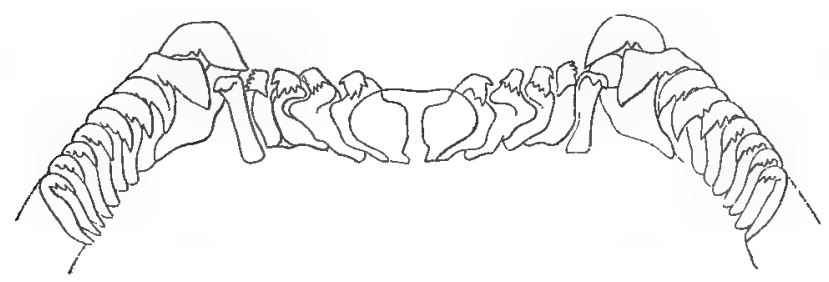

five on each side, oblique, the four inner imbricated; cuttingedge recurved with three to four points, in the fourth at the side, and furnished with a process winged outwardly, in the third and fourth obsolete, fifth sublinear, clavate. Lateral series of teeth on 
each side about seventy, the first by far the longest, gradually diminishing, hooked, pointed, denticulated behind at the bend, in the first externally hollowed, in the last obsolete; scape of the first wide, winged within, in the remainder simple, the middle produced within.

The neck-lappets of Eutropia pulla subcircular membranes; the right is the largest, margined with twelve or fifteen distinct cirrhi of almost equal length, and fimbriating the sides; the left has only eight or ten cirrhi. The operculigerous lobe is almost coextensive with the foot; it is furnished with three densely ciliated, flattish, pointed vibracula on each side; the middle ones are very short and inconspicuous; each bifid. The branchial plume is single, arcuated, with numerous close-set transverse vessels at the anterior end, which are long at their commencement and taper gradually to near the pericardium, as in Littorince. The lateral vibracula two or four, long, setose. Neck-lappet scalloped, with six or nine dentations or cirrhi, more developed on the pillar side. It walks like Cyclostoma elegans and some Littorine, by one-half of the longitudinal area bounded by a central incised line being extended and fixed; the other half is then brought up, and in like manner fixed, while the first half makes a progression, and so on. Thus half the foot is alternately in motion, giving the animal a lateral oscillatory progress._Clark, Moll. 321 .

\section{Fam. IV. LIOTIAD正.}

Operculum horny, with an external calcareous coat formed of numerous separate, pearl-like, shelly particles placed in spiral lines. Shell discoidal, white, spirally grooved or concentrically ridged. Aperture orbicular, more or less pearly within.

\section{a. Body of animal and whorls cylindrical, rounded.}

\section{Liotia.}

Shell variced; axis perforated or umbilicated; aperture circular ; throat pearly; lips thick.

1. L. granulosa. Delphinula g., Dunker.

2. L. Kraussii. Solarium cancellatum, Krauss.

3. L. cancellata. Delph. c., Gray=D. Cobiensis, Reeve.

The head of Liotia pulcherrima is proboscidiform; the tentacles subulate; the eyes on conspicuous peduncles at their outer bases; there are no intertentacular lobes, but a conical lobe on each side of the head external to the eye-peduncles; lateral membrane of the foot undulated, and furnished behind with three cirrhi. The operculum is arctispiral; the volutions being very narrow, numerous, and covered with a calcareous deposit which is articulated at regular intervals, giving the upper surface of the operculum a tessellated ap- 
pearance. The periphery is ornamented with radiating horny fibres. -Adams, P.Z.S. 1850 , p. 50. t. 8. f. 21 .

\section{Lippistes.}

Shell subdiscoidal; mouth round; lips scarcely reflexed.

1. L. cancellata. Cyclostrema c., Leach.

2. L. evoluta. Delph. e., Reeve.

b. Body and whorls compressed, subquadrate, flattened in front.

\section{ADEORBIS.}

Shell suborbicular, white, umbilicated; whorls spirally ribbed; aperture subquadrate, ovate, very oblique. Peristome continuous, simple; throat pearly. Operculum orbicular, shelly, circular, flat, elosely multispiral, with a frosted surface.

1. A. subcarinatus. Trochus s., Montague.

\section{Fam. V. TROCHID A.}

Operculum horny, of many gradually enlarging. whorls, not covered with a calcareous coat (fig. 80). No frontal fringe between the tentacula. Rostrum produced.
A. Operculum circular, many-whorled (fig. 80) (p. 158).

a. Shell top-shaped; aperture of shell contracted, quadrangular; whorls compressed, subquadrate, fat in front. Trochina. (Page 155.)

\$ Axis of shell imperforated, slightly concave in front.

\section{Pyramis.}

Shell conical, imperforated, flat in front; aperture subquadrangular, wider than long; pillar short, spirally twisted, and acute in front.

1. P. obeliscus, t. 39. f. 3.

\section{Cardinalia.}

Shell conical, imperforated, flat in front; aperture four-sided; pillar-lip simple above, without any groove, and ending in a simple point in front.

1. C. elata, t. 61 . f. 22,26 . 
$\$ \$$ Axis of shell imperforated, conically concave in front.

\section{Trochus.}

Pillar-lip twisted, simple; axial cavity smooth; throat smooth.

* Axial cavity moderate, smooth, conical.

1. T. niloticus, t. 43 , f. 1 .

2. T. asper.

$$
\text { ** Axial cavity very deep, conical. }
$$

*** Axial cavity very deep and wide, open. Infundibulum.

3. T. concavus.

\section{Rochia.}

Pillar-lip twisted, simple; axial cavity deep, -narrow, smooth, with a strong fold on the pillar-lip, and a deep sinus behind, near the whorl.

1. R. acutangula.

\section{Pracia.}

Pillar-lip twisted, simple; axial cavity deep, narrow, with a distinct narrow, central, spiral rib; throat striated.

1. P. elegantula. Trochus e., Gray.

\section{Anthora.}

Pillar-lip twisted, simple; axial cavity moderate, narrow, with several opake subspiral ridges.

1. A. tuberculata. Polydonta t., Gray.

\section{Polydonta.}

Pillar-lip two- or three-twisted; throat sulcated.

$$
\text { * Axial cavity smooth or slightly ridged. }
$$

1. P.? tiaratum, t. 64 . f. 6,11 .

2. P. sandwichense, t. $107 a$. f. 5. Frontal appendage distinct, lobed!

$$
\text { ** Axial cavity with regular spiral ridges. }
$$

\section{P. Hanleyanum.}

Lingual membrane of Polydonta umbilicatum linear elongate, transparent: Teeth $00 \cdot 5 \cdot 1 \cdot 5 \cdot 00$; central tooth small, laminar, longer than broad, rather contracted above, square below; apex rounded, slightly recurved; inner lateral teeth $5 \cdot 5$, similar, equal, lineal, rather oblique, with a rather large, thickened, rounded, slightly recurved apex; outer lateral teeth very numerous, hair-like, linear, equal, similar, with the apex recurved. 
8. Clanculus.

Pillar-lip and throat toothed; forehead with a toothed crest on each side near the tentacula?

* Outer lip of adult with a large tooth.

1. C. Pharaonis, t. 42 . f. 3 .

2. C. patagonicus, t. 48 . f. 2 .

3. C.? Isabellæ, t. 108. f. 4.

4. C. limbatus, t. 63 . f. 1,6 .

5. C. Maugeri.

** Outer lip of adult smooth.

6. C. articulatus.

$\$ \S$ Axis of shell imperforated and fat in front.

9. Ziziphinus.

Shell top-shaped; aperture quadrangular; throat smooth.

* Whorls flat in front.

1. Z. vulgaris, t. 43 . f. 3 , t. 107. f. 2 ?; Forbes \& Hanley, B. $M$. t. E.E. f. 1 .

2. Z. erythroleucos, t. 107. f. 3 .

3. Z. conulus?, t. 107. f. 2.

4. Z. granulatus ?, t. 43. f. 2 ; Forbes \& Hanley, B. M. t. D.D.f. 4.

5. Z. diaphanus, t. 64. f. 1-5.

6. Z. alabastrites, Forbes \& Hanley, B. M. t. E.E. f. 2.

** Whorls rather rounder and convex in front.

7. Z. tenuis.

8. Z. punctulatus.

9. Z. Tigris.

The branchial plume of the Ziziphini is acutely pointed in front, increasing in breadth behind to its arrival at the region of the pericardium. It is usually long, tapering like a leaf to a fine point, and composed of one or more rows of short, close-set strands, accompanied in some species, we think, by the rudiments of mucous fillets. The male organ of Ziziphinus is a narrow, white, tough, gently arcuated and subulate filament, lining or attached from base to point to one side of the branchial leaf. The orifice of the ovary is placed below the rectum.-Clark, Moll. 318, 319 .

Central tooth of Ziziphinus vulgaris laminaceous, lanceolate; three parts at the base oval, suddenly wider, tip recurved, sharp, serrulated on both sides; lateral teeth on each side five, imbricated, and shaped like the half of the central one; the last somewhat different in shape; lateral series of teeth sixty and upwards on each side; the first by far the stoutest, wide, the base dilated behind, the hook toothed 
below with tubercles, the remaining teeth slender, with a compressed hook, pointed; in the inner one toothed below, serrulated on both

Fig. 81.-Teeth of Ziziphinus vulgaris.

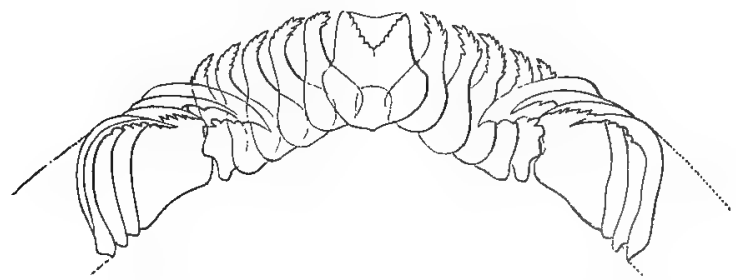

sides, in the middle ones pectinated on each side, in the last obsolete; scape slender, simple, furnished before the base with an external spur-shaped process (fig. 81).

Lingual membrane of Ziziphinus vulgaris elongate, linear, transparent. Teeth $00 \cdot 1 \cdot 5 \cdot 1 \cdot 00$; central square, about as long as broad; apex rounded, very slightly recurved; inner lateral teeth $5 \cdot 5$, thin, half-ovate; apex rounded, recurved; central lateral teeth strong, claw-like, compressed, curved, acute; outer lateral teeth very numerous, hair-like, sinuous, subequal, innermost rather largest, curved at the tip.

Lateral vibracula of Ziziphinus vulgaris $4 \cdot 4$, the neck-lappets on each side large, subrotund, symmetrical, plain on the edges; headlappets none.

The head-lappets of Ziziphinus Montagui are each split into five short, flattish cilia, fimbriated at the sides; neck-lappets plain, that on right side largest, and often rolling itself up like a branchial fold.

Muzzle of Ziziphinus granulatus elongate; mouth with a pair of oval, horny laminæe, and a very short lingual riband passing to the cesophagus ; head-lobes very small, lateral; neck-lappets two, similar, large, pendent, and sinuated; lateral vibracula four on each side, partially retractile into a tubular sheath, and in constant motion.-Clark, Moll. 305.

\section{Thalotia.}

Shell conical, turrited, solid, granulated; axis imperforated ; aperture longer than wide; pillar-lip subtruncate, tubercular; outer lip thickened and crenulated within. Operculum many-whorled.Adams, Gen. Moll. 420. t. 48. f. l.

Australia; New Zealand.

1. T. conica. 
$\$ \S \S \S$ Axis of shell perforated or umbilicated, more or less completely covered with a callous deposit; inner edge of whorls simple.

\section{$\uparrow$ Pillar-lip regularly arched.}

\section{Oxystele.}

Shell top-shaped, solid, smooth; axis perforated, covered with a callous deposit; aperture square; pillar flattened, gradually blending into the thin outer lip.

1. O. merula, t. 42 . f. 8.

2. O. cærulescens. Photinula c., Adams, Gen. Moll. t. 48. f. 9 a, operculum.

Some of the species of this genus are very like species of Labio.

\section{Trochiscus.}

Shell subdiscoidal, covered with a periostraca; axis umbilicated, open ; aperture nearly circular ; inner lip thin, flattened, rather produced in front, gradually blending into the outer lip. Operculum horny, of many gradually enlarging whorls, with a thin, free, raised external edge.

1. T. Norrisii.

Trochiscus is very nearly allied to Gibbula. Trochus oculus from Australia appears to be the same in a semi-fossil state.

\section{Gibbula.}

Shell depressed, conical, solid; axis perforated, more or less open ; aperture subrhomboidal; pillar arched gradually. Operculum of many gradually enlarging whorls.

\section{* Axial cavity moderate.}

1. G. cineraria, t. 42 . f. 5, 6 ; Forbes \& Hanley, B. M. t. D.D. f. 1 .

2. G. —?, t. 42 . f. 9 .

3. G. ? ?. t. 42 . f. 2 .

4. G.?? -?, t. 42 . f. 4.

5. G. —?, t. 42 . f. 1 .

6. G. - ? t. t. 5l.f. $1,2$.

7. G. tumida. Trochus t., Forbes \& Hanley, B. M. t. D.D. f. 2.

8. G. magus. Trochus m., Forbes \& Hanley, B. M. t. D.D. f. 3.

9. G. pulligo.

10. G. lævis.

The species of this genus gradually pass into Omphatius.

Central teeth of Gibbula magus broad, lanceolate; apex lanceolate, denticulated on each side; four or five inner lateral linear-lanceolate, 
arched, curved, denticulated on each side; outer central strong; lateral teeth numerous, hair-like, innermost rather larger.

The mantle of Gibbula magus shows an incomplete, tubular, branchial fold; head-lappets two, suboval, approximating; large, long, fimbriated on the edges, hanging over the head; lateral vibracula $3 \cdot 3$, fimbriated; neck-lappets large, suboval, the columellar one two- or three-lobed, the dextral one plain; operculum of five or seven spiral turns.-Clark, Moll. 311.

The two head-lappets of Gibbula cineraria almost coalesce, forming a crenated veil ; the neck-lappets are suboval and well-developed, that on the pillar side with three or four thick, subcylindrical, pendent fillets from the lower edge, the other plain; lateral vibracula $3 \cdot 3$, sheathed at the base; operculum serrated on the edge.-Clark, 312 .

Teeth of Gibbula cineraria numerous, in curved cross lines; central elongate; inner lateral $5 \cdot 5$, rather oblique, with a transverse hook at the apex, gradually larger externally; outer one with large hooks ; outer lateral numerous, hair-like, hooked.

Central tooth of Gibbula cineraria heart-shaped, produced at the base in the middle, above contracted by a short neck on both sides, rounded and winged, forming a transverse oval head; cutting edge transverse, denticulated; lateral teeth on each side five, imbricated, shaped like the half of the central one, but towards the sides gradually changing in shape; the neck wider, cutting edge oblique, and furnished with a plate directed inwards, in the last the plate is large and subquadrate. Lateral series of teeth on each side about nimety, slender, with a plain hook, linear, gradually diminishing, in the last

Fig. 82-Teeth of Gibbula cineraria.

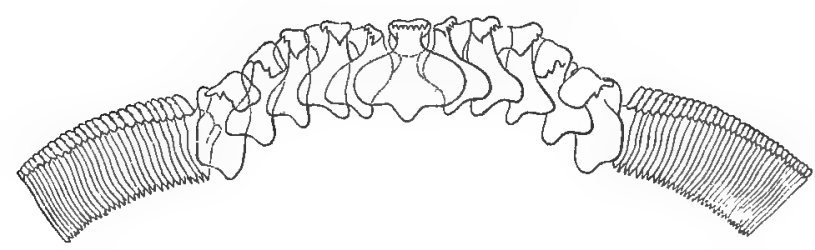

obsolete, in the inner ones denticulated only at the base, in the middle ones on all sides; scape compressed, in the first furnished behind with a wing, in the middle ones simple, produced under the hook, slightly bent towards the base, attenuated, in the last laminaceous (fig. 82).

The head-lappets of Gibbula umbilicata are small, very anterior, distinctly separated, and fringed with six short cilia; the neck-lappets are large, the pillar one fringerl, the other plain, sinuated; lateral vibracula $3 \cdot 3$, sheathed; operculum multispiral.

The two head-lappets of Gibbula tumida are small, delicately denticulated; the neck-lappets are lurge and discordant, the pillar one gently scalloped; the right one is largest, plain-edged; tentacula 
setose ; the lateral vibracula are $3 \cdot 3$, setose, half-retractile; branchial plume minute; operculum multispiral.

The mantle of Gibbula lineata is even, but the pillar-lappet often forms a branchial fold; head-lappets two, small, suboval, lateral; the neck-lappets are only a continuation of the operculigerous lobes, the one on the pillar side breaking into eight or ten dentations, the outer one plain.-Clark, Moll. 309 .

\section{Margarita.}

Shell subglobose, thin, polished or striated; axis umbilicated, open ; aperture nearly circular; pillar-lip ending in a point; throat iridescent. Operculum of many rather gradually enlarging whorls.

1. M. helicina, Adams, Gen. Moll.t. 49. f. 60, operculum; Forbes \&. Hanley, B. M. t. C.C. f. 4.

lingual membrane of Margarita antarctica linear, transparent, rather dilated in front. Teeth $00 \cdot 5 \cdot 1 \cdot 5 \cdot 00$; central tooth elon-

Fig. 83.-Teeth of Margarita antarctica.

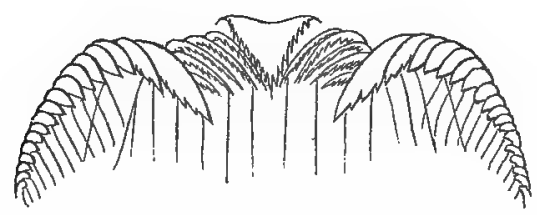

gate, dilated in front; upper edge concave, very transparent; inner lateral $3 \cdot 3$ or $5 \cdot 5$, linear, bristle-like, arched, acute, rather far apart ; middle lateral strong, transparent, with a strong transparent apical hook; outer lateral very numerous, crowded, slender, hooked at the end (fig. 83).

The skin of Margarita is reticulated. Tentacles hispid, with very minute tubercles, channeled above, with a minute internal lobe. Eyepedicel free, short, united by a frontal reil. Foot with a large anterior lobe and lateral beards, grooved above behind.-Lovèn.

Prehensile collar of Margarita helicina distinct. Teeth $00 \cdot 6 \cdot 1 \cdot 6 \cdot 00$; the central thirteen subsimilar, strap-shaped ; apex recurved, denticulated, the middle one rather the broadest; lateral numerous, subulate, recurved at the tip.-Alder.

\section{+† Pillar-lip slightly twisted in front.}

\section{Tegula.}

Shell elongate, top-shaped; axis imperforate, covered with a callous deposit; pillar spirally twisted, ending in a large prominent tubercle in front.

1. T. pellis-serpentis.

The axis of this shell is rarely perforated. 
†t十 Pillar-lip with a small notch in front, forming a slight tooth.

\section{Chlorostoma.}

Shell top-shaped, smooth, solid; axis umbilicated or perforated, more or less completely covered with a callous deposit; aperture oblique; pillar-lip arched, with a slight notch, forming a small tooth in front; outer lip angular behind. Operculum horny, manywhorled.

1. C. atrum, Adams, Gen. Moll. 428. t. 49. f. I $a$, operculum.

Some specimens of the species of this genus are perforated, or even umbilicated, when the type is imperforated.

\section{Omphalius.}

Shell top-shaped, granulated, solid; axis perforated, open; inner edge of whorls sharply keeled; aperture subquadrate; pillar-lip with a notch, forming one tooth and sometimes more teeth in front. Operculum circular, flat, many-whorled.-Adams, Gen. Moll. 429. t. 49 . f. $2 a$.

$$
\text { * Shell conical, granulated; outer lip contracted. }
$$

1. O. quadricostatus.

2. O. Byronianus.

3. $\mathrm{O}$, aureotinctus.

4. O. maculatostriatus.

5. O. lividomaculatus.

$$
\text { ** Shell conical; outer lip extended. }
$$

6. O. excavatus.

$$
\text { *** Shell depressed, smooth. }
$$

7. O. roseus.

$$
\text { **** Shell conical, elevated, tubercular. }
$$

8. 0 . declivis.

\section{Monilia.}

Shell depressed, subconic, thick, spirally striated; axis perforated, open; inner edge of whorls with a striated callous band; aperture round; pillar-lip arched, with a notch in front forming one or more small tubercles. Operculum of a few gradually enlarging whorls.Adams, Gren. Moll. t. 49. f. $3 a$.

1. M. callifera.

\section{§§§ Axis umbilicated; inner edge of whorls crenated.}

\section{Philippia.}

Shell conical, umbilicated; whorls compressed, subquadrate, with 
two external ribs; inner edge with two crenated ribs; axis umbilicated. Operculum homy, cblong, circular; whorls five or six, rapidly enlarging.-Adams, Gen. Moll. t. 25. f. $8 a, b$.

1. P. lutea. Solarium 1., Philippi, Moll. Sicil. i. 174; Adams, Gen. Moll. t. 25. f. 8, shell and operculum only.

"Animal exactly like Trochus." " "Operculum very thin, of many whorls, with a central calcareous nucleus on the inner side."Philippi.

b. Shell subglobose; aperture contracted; whorls subcylindrical, rounded in front. Monodontina. (Page 147.)

+ Pillar twisted, with a more or less distinct tooth in front.

20. Monodonta.

Shell conic, ovate, solid, grooved and granulated; axis imperforated or covered; aperture ovate; pillar-lip with two strong opake tubercles; outer lip grooved; throat pearly ; lateral beards $4 \cdot 4$. Operculum with many gradually enlarging whorls.

1. M. ? Osilin, t. 43. f. 7, 8.

2. M. tæniata, t. 63 . f. 15,17 .

3. M. canalifera, t. 64 . f. $26,29$.

\section{Turcica.}

Shell conical, thin, granular ; axis imperforated; aperture longer than wide; pillar thick, spirally twisted behind, blunt and prominent in front; outer lip thin, simple. Operculum —? Animal - ? 1. T. monilifera, Adams, Gen. Moll. 423, t. 48. f. 3.

\section{Labio.}

Shell conical, ovate, solid, grooved, and often granulated; axis perforated, at length covered; aperture roundish; pillar-lip thick, rounded, with a slight prominence or tubercle in front. Operculum horny, many-whorled.

1. L. fragaroides, t. 42 . f. 7.

2. L. - ?, t. 108 . f. 6 .

3. L. constrictus, t. 63 . f. $23,27$.

4. L. striolatus, t. 63. f. 18, 22 .

5. L. zelandicus, t. 64. f. 12,15 .

6. L. cingulatus, t. 64 . f. $16,20$.

The lingual membrane and teeth of Labio crassus are like those of Gibbula umbilicata. See figure of “Tongue," Osler, Phil. Trans. 1832, t. 14. f. '2. 


\section{†十 Pillar regularly arched.}

\section{Livona.}

Shell subglobose; axis umbilicated, with a notched callus near the mouth; aperture circular. Operculum horny. Animal: lateral beards numerous.

$$
\text { * shell umbilicated. }
$$

1. L. Pica, t. 41. f. 7 .

** Shell not umbilicated, rarely perforated. Chrysostoma.

2. L. paradoxa.

In the British Museum there is a specimen of L.paradoxa, tubercular and perforated, nearly like $L$. Pica.

c. Shell depressed; aperture contracted; whorls cylindrical, more or less separated. Angarina. (Pages 147, 155.)

\section{Angarus.}

Shell top-shaped or discoidal, umbilicated; whorls rounded, scaly or spinal; aperture circular, entire; peristome continuous, with a canal on hinder edge. Operculum orbicular, horny.

1. A. Delphinus, t. 43. f. 4, 5, t. 107. f. 7 .

2. A. niger, t. $107 a$. f. 1 .

Kiener (Icon. t. 1. f. 1) represents the eyes on short pedicels; the sides of the body not fringed; the operculum orbicular, horny, of many gradually enlarging whorls.

\section{Vitrinella.}

Shell top-shaped, thin, transparent; whorls circular ; axis umbilicated ; aperture circular ; peristome continuous, thin, simple. Operculum horny.

1. V. valvatoides, Adams, Gen. Moll. t. 49. f. 7.

The head of Vitrinella divisa is rather long, broad, with horny jaws and a lingual riband. Tentacula long, flattish, and obliquely ciliated. Eyes large, black, lateral, on the basal rounded inflation; no distinct pedicels. Head-lobes none. Neck-lappets two; the right narrowish, flat, semiserrated; the one on pillar side shorter, more oval, and plain. Foot subtruncate, subauriculated in front. Operculigerous lobe plain; lateral vibracula $3 \cdot 3$, obliquely ciliated. Operculum of six or eight spiral turns.-Clark, Moll. 315.

Operculum of Vitrinella divisa spiral, circular, of many very gradually enlarging whorls. Teeth : central 6 or 8 ; lateral numerous, hair-like.

Tentacles of Vitrinella divisa linear, ciliated. Neck with a lobe on each side, that on the left short and simple, on the right elongate, 
serrated. Foot very narrow, with a long beard on each side in front ; lateral fringe with three ciliated beards on each side. Operculum orbicular, horny, of six or eight whorls. Penis on right side in front of neck-lobe; vent further back on same side.

The right neck-lappet of Trochus is always larger than the left, which, bowever, is also bifid, but plain, and never ornamented, fringed or serrated, as is sometimes seen on the right one, as for instance in Vitrinella divisa._Clark, Moll. 516.

The male organ of Vitrinella Cutleriana is a rather long, flat, smooth filament, horizontally exserted, close under the right tentaculum.-Clark, Moll. 319.

The animal of Vitrinella Cutleriana only differs from that of $V$. serpuloides in the cilia on the tentacula and vibracula being more sparse, and the foot less auriculated in front. The operculum of three or four lax whorls._Clark, Moll. 316.

The animal and operculum of Vitrinella nitens are equally similar to the other two.-Clark, Moll. 316.

\section{Valvatella.}

Shell conic; whorls rounded, with laminar periostraca, axis $\mathrm{m}$ perforate; aperture circular; peristome simple. Operculum circular, horny, many whorls.

1. V. Grœnlandica.

d. Shell subturrited, smooth, polished; aperture subovate, rather elongate; whorls laterally compressed; pearly coat greenish; axis imperforate. Canthiridina. (Pages 147, 155.)

\section{Canthiridus.}

Shell ovate, conical; spire conic; whorls slightly keeled; pillar with a small tooth in front; outer lip entire; throat smooth. Operculum circular.

1. C. iris.

2. C. purpuratus. Operculum circular, of many whorls.

3. C. Zealandicus. Operculum circular, of many whorls.

\section{Elenchus.}

Shell conical, turrited, smooth, polished; whorls rounded; axis imperforated; aperture ovate, longer than wide; throat pearly; pillar-lip with a tooth in front; outer lip thickened and grooved internally. Operculum circular.

1. E. irisidontes, t. 125. f. 8. Operculum circular, smooth.

Teeth $00 \cdot 5 \cdot 1 \cdot 5 \cdot 00$; the fifth or outer central teeth large; the hooks denticulated; the lateral teeth hooked, the first denticulated (fig. 84). 
Fig. 84.-Teeth of Elenchus (Australia).

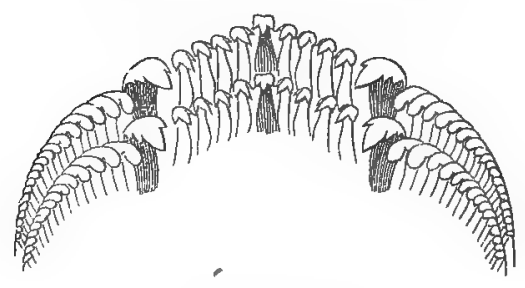

29. Bankiva.

Shell turrited, porcellaneous, smooth, polished; inner coat iridescent ; axis imperforated ; aperture ovate, longer than wide ; pillarlip twisted, truncated in front; outer lip acute; throat porcellaneous. Operculum ——? Animal _-?

1. B. varians, Adams, Gen. Moll. 425. t. 48. f. 6 .

B. Operculum ovate, few-whorled. Shell subglobose, solid (p. 147).

30. Aradasta.

Shell top-shaped; whorls rounded, granulately ridged; axis perforated, sometimes masked; mouth ovate; pillar with a small tooth in front; outer lip thick, blunt, internally crenated; throat more or less pearly. Operculum ovate, suborbicular, of few rapidly enlarging whorls; lateral filaments $(4 \cdot 4)$ elongate.

1. A. canaliculata. Trochus c., Quoy, Voy. Astrol. t. 64. f. 21, 23.

2. A. denigrata, Adams, Gen. Moll. t. 47. f. $6 a$, operculum.

31. Otavia appears chiefly to differ in the outer lip having a distinct, thickened, marginal varix. The animal and operculum are nnknown.

\section{Fam. VI. STOMATELLID压.}

Foot large, fleshy, developed posteriorly. Shell more or less earshaped, of a few rapidly enlarging whorls; aperture open, expanded. Frontal lobes between the tentacula two, distinct, lobed. Mantle and shell entire; sides without filaments. Gill single, lateral. Operculum horny, whorls many, gradually enlarging; sometimes wanting.

a. Operculum distinct. Animal retractile into shell.

\section{Stomatelia.}

Shell suborbicular, depressed, spirally grooved; spire conic; whorls rounded; aperture wider than long. Animal spiral, retractile 
into the shell; frontal lobes triangular, fringed on the edge. Foot round, enclosed; lateral membrane very wide, fringed on the edge. Operculum horny, thin, circular, many-whorled.

1. S. maculata, t. 109 . f. 1,3 .

2. S. sulcifera, Adams, Gen. Moll. t. 49. f. 8 b, c, operculum.

\section{b. Operculum none. Animal larger than shell, produced behind.}

\section{Stomatia.}

Shell subspiral, oblong; whorls keeled or tubercular, plicate near the sutures; spire prominent; aperture wider than long, pearly within; frontal lobes digitated; foot very large, tubercular, produced behind; lateral membrane fringed, with a fringed crest under the eyes on the left, and a slight projecting fold on the right side, leading to the respiratory cavity. Operculum none.

I. S. rubra, Adams, Gen. Moll. 436. t. 49. f. 9.

The animal of Stomatia and Gena has, like Harpa, the habit of throwing off the hinder part of the foot when frightened, or placed alive in spirits.

\section{Microtis.}

Shell suborbicular, spiral, depressed, with two tuberculated ridges; spire slightly prominent; aperture very large, wider than long, pearly within ; pillar-edge spiral, visible to apex of spire. Living on sand within tide line. Animal like Stomatia, but with a deep anterior fissure for the head, and the front edge bilobed. Operculum none.

1. M. tuberculata, Adams, P. Z. S. 1850,36 . t. 8. f. 8-12; Gen. Moll. t. 50. f. 1.

\section{Gena.}

Shell oblong, elongate, ear-shaped, subspiral; spire flattened, nearly obsolete; aperture large, oblong. Animal uval, depressed; frontal lobes plumose. Foot very large, tubercular, produced behind. Lateral membrane not fringed, more or less extended, and partially covering the shell. Operculum none.

1. G. lutea, t. 109. f. 5 .

2. G. nigra, t. 109. f. 4 .

The foot elongated behind, the shell granulated above; when the animal is put in spirits, the hinder part of the foot suddenly contracts into a subglobular form, and separates by a transverse section from the rest of the foot.

Lingual membrane of Gena elegans linear elongate, rather dilated in front, transparent. Teeth $00 \cdot 5 \cdot 1 \cdot 5 \cdot 00$, placed in a rather arched series; central tooth narrow, elongate, contracted, and very narrow in the upper part; apex small, triangular, reflexed, denticulated on the edge; inner lateral teeth $5 \cdot 5$, linear elongate, placed 
obliquely ; apex small, triangular, reflexed, denticulated on the edge ; outer lateral teeth very numerous, hair-like, curved at the end (fig. 85).

Fig. 85.-Teeth of Gena elegans.

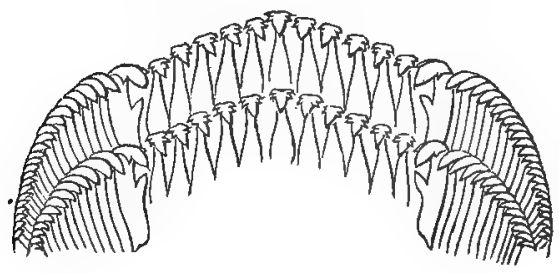

5. BRodERIPIA.

Shell shield-shaped, oblong ovate, flattened; apex posterior, subinvolute, not spiral ; aperture very large, ovate, within iridescent, pearly, Animal —? Operculum -?

1. B. rosea, Adams, Gen. Moll. t. 50. f. 3.

\section{Suborder II. Schismatobranchia.}

Gills in the form of two plumes on the left side of the gill-cavity, one on each side of the slit on the mantle. Body and shell spiral. Eyes peduncled. Sides of the foot tubercular, bearded above. Central teeth large, very unequal, dissimilar (p. 136).

\section{Fam. VII. SCISSURELLIDE.}

Mantle-slit in front. Gills —? Sides with very long slender beards. Tentacles subulate, elongate, ciliated or serrated. Teeth ? Foot narrow, truncate in front, tapering behind. Operculum horny. Shell spiral; whorls keeled, with a slit in front of the keel, which is gradually filled up as the shell enlarges.

This family, though it contains only a single recent genus, of small size, has many fossil representatives of considerable size and diversity of form.

Fig. 86.-Animal of Scissu-

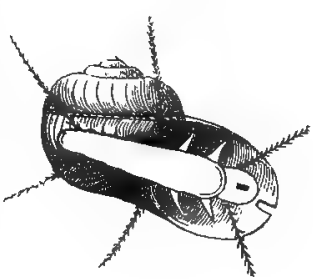

\section{Scissurella.}

Shell depressed, spiral, transparent, widely umbilicated; spire short; whorls keeled, with a narrow, subposterior slit at the end of 
the keel; aperture suborbicular. Operculum circular, horny, thin, subspiral.

1. S. lævigata, $D^{\prime} O r b$.

\section{Fam. VIII. HALIOTIDA.}

Operculum none; frontal lobes none? Mantle with a slit, and shell with a series of holes on pillar side. Gills two, separate on pillar side. Shell ear-shaped, with a series of holes over the mantleslit, pearly within; adductor muscle single, central.'

a. Foot moderate, not produced, and grooved behind. Shell rugose.

\section{Haliotis.}

Shell ear-shaped, oblong, with a spiral ridge on the left side, with holes in front which are gradually filled up behind as new ones are formed in front.

1. H. tuberculata, t. 109. f. 2, $2 a, 6$, t. 110. f. 5, 7 ; Forbes \& Hanley, B. M. t. C.C. f. 3 .

Central tooth of Haliotis tuberculata small, depressed at the base, rounded and produced, above covered with a convex plate which is wider and unarmed; inner one on each side single, transverse; beam-

Fig. 87.-Teeth of Haliotis tuberculata.

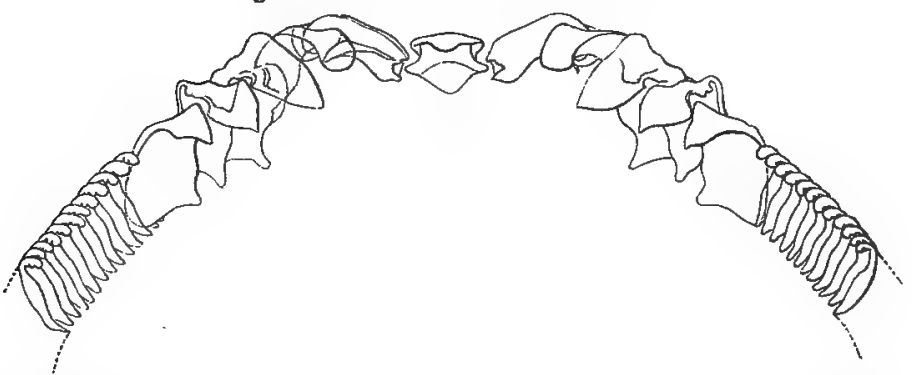

like, deeply notched on the inside, rounded on the outside, furnished behind beyond the middle with a spire; lateral series of teeth aboüt seventy ; first four by far the largest, wide and misshapen; hook of the first rounded, of the second and third lanceolate, at the flexure notched or denticulated, of the fourth short and triangular; the others somewhat equal in size, with an oval hook, denticulated behind at the bend (fig. 87).

Haliotis, in common with Fissurella, has a double symmetrical branchial plume, two auricles, and a ventricle embracing the rectum, which terminates between the roots of the branchiæ. No operculum. 
The Trochi have only one auricle and one branchial leaf, a heart not in contact with the intestine, and the rectum far removed from it, at the front of the right side. An operculum.-Clark.

Ear-shells (Haliotis) are found as far north as Kamtschatka: one lives in deep water near Fort Simpson, Columbia. - Sir George Simpson. And as far south as New Zealand, where they are used for food.

\section{Padollus.}

Shell ear-shaped, subcircular, with two parallel spiral ridges; the outer perforated in front as in Haliotis; the other simple.

1. P. tricostalis.

\section{b. Foot very large; hinder part much produced, and furnished} with a deep longitudinal groove. Shell polished.

\section{Teinotis.}

Shell depressed, elongate, ear-shaped, polished, with a single spiral ridge pierced with holes in front; spire small; aperture much longer than broad. Foot very large, thick, much produced behind, and furnished with a deep longitudinal groove above; lateral fringe produced to the end of the groove.

1. T. Asinina, Adams, Gen. Moll. 442. t. 50. f. 6 .

\section{Suborder III. Dicranobranchia.}

Gills, two symmetrical plumes on the back of the neck, with the vent between them. Body and shell symmetrical, Central teeth unequal, middle one small, similar, outer lateral large, dissimilar. Sides of the foot tubercular, obscurely bearded on its upper edge. Eyes slightly tubercled or sessile. Operculum none (p. 160).

\section{Fam. IX. FISSURELLIDAE.}

Foot dilated; upper side with a series of short tentacles. Body and shell short, broad, conic. Gills two, separate, symmetrical.

a. Vent anterior. Shell external, or partly covered with the mantle, entire, truncated in front.

\section{Scutus.}

Shell depressed, oblong, smooth or striated, truncated in front; edge smooth.

1. S. Unguis. Parmophorus australis, Quoy, t. 111.

2. S. elegans. P. australis, Rüppell, t. $43^{*}$. f. $6,7$. 
Tongue of Scutus linear elongate, broad, brown. Teeth $00 \cdot 5 \cdot 1 \cdot 5 \cdot 00$; central very broad, transverse; inner lateral linear, narrow ; upper part narrow, recurved ; central lateral strong, large ;

Fig. 88.-Teeth of Seutus australis.

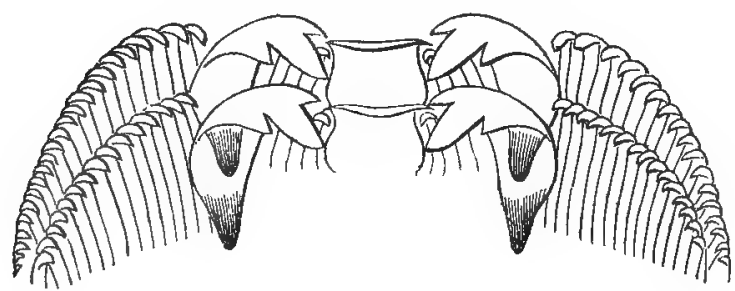

apex hooked, transparent; external lateral numerous, linear, with a small, transparent, apical hook (fig. 88).

\section{Tugalia.}

Shell oblong, narrowed in front; back elevated, cancellated; apex posterior and recurved; aperture crenulated on the edge, deeply sinuated in front.

1. T. elegans.

b. Vent anterior. Shell exposed or partly covered with the mantle, with a slit in the front margin.

\section{Emarginula.}

\section{* Mantle enclosed.}

1. E. fissura, Miuller, t. 70. f. 4, 9, t. 113. f. 5. Var. rosea, Forbes, B. M. t. B.B. f. 1, 2,3 .

2. E. elongata, t. 110 . f. 3.

3. E. crassa, Forbes \& Hanley, B. M. t. C.C. f. 1.

** Mantle much expanded, partly covering the shell.

4. E. Cuvieri, t. 114. f. 8.

The young of Emarginula fissura have a very minute, recurved, spiral shell, with rapidly enlarging and finely striated whorls without any slit.--Lovèn.

Central tooth of Emarginula crassa laminaceous, flat, obliquely subquadrate, wider at the base, the cutting edge smooth ; four lateral imbricated, laminaceous, oblong, first and second truncated above, third and fourth apiculate, and furnished outside with a longitudinal bent crest. Lateral series of teeth about sixty; first by far the largest and thickest, the hook lobe-bearing behind; scape within with a prominent tubercle, base within sharply produced, furnished 
outside with a condyle, to which corresponds the trapezoidal cavity of the apical minute bone; other teeth equal in shape; hook ovatelanceolate, serrulated.-Lovèn.

\section{Hemitoma.}

Shell conical, compressed, cancellated or tuberculated; vertex inclined towards the posterior margin; aperture large, with fold on the front edge.

1. H. emarginata.

2. H, octoradiata.

\section{Chyprdina.}

Shell ovate, conical, radiately ribbed; vertex acute, central, not recurved; aperture crenulated on the edge; muscular scar fungiform; anal groove and emargination very small, indistinct.

1. C. notata.

\section{c. Vent anterior? Shell none.}

\section{Deridobranchus.}

"Body like an Emarginula, without any shell. Front of the mantle plaited, covering two pectinated gills. Upper tentacles none, lower two. Eyes at the base of the lower tentacles."

D. Argus, Ebr. Orbicular, orange, very finely cinnabar-dotted; the larger dots with an orange ring, and a transverse, curved, hyaline band. Red Sea.

d. Vent dorsal, subapical. Mantle and shell with a sitit or perforation near the tip.

$\uparrow$ Shell exposed. Anal slit subapical, guarded by a shelly channel within.

\section{Puncturella.}

Shell conical, cancellated, radiately ribbed ; apex elevated, recurved, obliquely spiral; a linear perforation in front of the apex in the line of an elevated rib; aperture crenulated on the edge; cavity with a vaulted plate over the anterior perforation; muscular scar crescentic. Head proboscis-shaped; tentacles subulate; eyes on protuberances on the outer base; mantle-edge simple, produced into a tube emitted through the subapical slit; branchial plumes two; anal siphon prominent; lateral fringe of cirrhi interrupted behind.

1. P. Noachina, Forbes \& Hanley, B. M. t. B.B. f. 4, 5, 6 . 
†† Shell more or less exposed. Anal slit simple within.

\section{Rimula.}

Shell conical, cancellated and radiately ribbed; apex elevated, recurved, entire, a linear perforation on the upper part of the front side, half-way between the margin and vertex; mouth crenulated on the edge; cavity simple, without any shelly plate; muscular scar crescentic, interrupted in front. Living in sandy mud.

1. R. exquisita, A. Adams, P. Z. S. 1851, 226.

2. R. conica, $D^{\prime}$ Orb. Amér. Mérid. t. 78. f. 10, shell only.

\section{Macroschisma.}

Animal narrow, elongate, with the shell near the hinder end. Shell oblong, elongate, radiately striated, elevated, and subtruncate in front; apex anterior; anal aperture large, elongate, on the front slope of the shell.

1. M. maxima, A. Adams, t. 51. f. 5.

"The shell is on the hinder end of a very elongated body, like 'Testacellus, not wider than the shell."-Cuming.

Fissuridea (pileus) has a subconic, cap-like shell, with the apex near the hinder margin, and a narrow perforation.

\section{Fissurella.}

Shell conical, radiately ribbed; apex subanterior or central ; anal perforation oblong, subapical ; aperture wide, oblong; cavity simple ; mantle enclosed, bearded on the edge ; anal siphon short, projecting.

1. F. costata, t. $43^{*}$. f. 1-4.

2. F. radiosa, t. $43^{*}$. f. 5 , t. 113 , f. 1 .

3. F. græca?, t. 112. f. 1, t. 113. f. 6, 7 ; young, t. 113. f. 4 . F. reticulata, Forbes \& Hanley, B. M. t. B.B. f. 7 .

4. F. patagonica, t. 113. f. 2 .

5. F. maxima, t. 113 . f. 3 .

The shell of the young animal is entire, subspiral, with a perforation in front of the subspiral apex, which is at length destroyed by the extension backwards of the anal perforation.

Fig. 89.-Teeth of Fissurella.

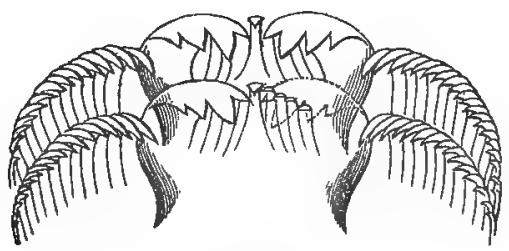

Lingual membrane of Fissurella elongate, broad, linear. Teeth : 
central series $1 \cdot 5 \cdot 1 \cdot 5 \cdot 1$; central small, laminal, narrow at top, wide below; inner lateral $4 \cdot 4$, linear, similar, subequal, oblique; apex rounded, slightly recurved; central lateral very large, versatile, capable of covering the inner lateral, conical, claw-like, transparent, curved, acute at the tip, with a large notch at the inner side near the base; outer lateral very numerous, hair-like, transparent; apex bent, hooked (fig. 89).

\section{Cuypidelta.}

Mantle partly covered by the edge of the shell, double-edged; edges fringed and crenated; anal siphon fringed, exposed; foot large, fleshy, with a few beads on the front part of the sides. Shell ovate, shield-shaped, radiately rugose ; front edge sinuous, subtruncated; anal perforation elongate, subanterior.

1. C. pustula.

\section{Capiluna.}

Mantle partly reflexed on the edge of the shell, bearded on the edge; anal siphon projecting. Shell oblong, cancellated; apex subcentral; anal perforation large, oblong; aperture expanded, crenulated on the edge; inner edge of the anal perforation callous, and rather produced behind.

1. C. Cuvieri, t. 110. f. 6.

This genus differs from Lucapina in the shell not being permanently covered by the mantle.

\section{$++\dagger$ shell permanently covered by the mantle; edge rounded, crenated.}

\section{Fissurellidata.}

Mantle large, thickened on the edge; foot very large, elongate. Shell depressed, oval, slightly radiated; anal perforation very large, subcentral ; aperture open, with a smooth margin, thickened on the inner edge.

l. F. hiatula.

2. F. megatrema, t. 112 . f. 2 .

\section{Lucapina.}

Mantle large, thin. Shell oblong; depressed, cancellated; apex subcentral; anal perforation large, simple; aperture expanded; edge crenulated.

1. L. cancellata.

2. L. crenulata. 
+十+t Shell permanently covered by the mantle; edge acute, double-grooved.

\section{Pupillia.}

Mantle very large, covering the foot, smooth; foot granulated. Shell conical, smooth; anal perforation very large, subcentral ; aperture ovate; margin entire, with a sharp, white, thinned edge.

1. P. apertura, t. 269. f. 5. Pupillaea aperta, Krauss.

II. Heteroglossa. Teeth pellucid, in five to eight longitudinal series, variable in form, the larger ones with opake black tips. Foot without any lateral fringe. Shell symmetrical. (See p. 136.)

\section{Suborder IV. Cirrhobranchia.}

Gills two, symmetrical, tufted on the back of the neck. Body elongate-conical. Shell conical, tubular, with an apical opening. Lingual membrane wide, ovate; central series one-toothed; lateral series with one tooth; limb laminated (p. 162).

\section{Fam. X. DENTALIAD五.}

Foot small, conical; sides simple, Budy and shell elongate-conical ; apex pierced.

Body cylindrical, conical. Gills : two, symmetrical, sublateral, and somewhat post-centrally situated organs, having their bases fixed on and hanging from the concave surfaces of the animal, with their points vertically parallel to the bases; they are united at their inner surfaces by a bridle of branchial strands arranged symmetrically. Heart at the ariterior end of the branchial cavity. Vent at the base of the branchial cavity under the mantle, about the middle of the shell. Head rudimentary. Tentacles and eyes none. Lips bearded. Mantle circular, thick, fleshy, and covering the foot in front, thin posteriorly, and attached to the shell near its hinder extremity. Foot central, conical, with two symmetrical side-lobes mounted on a long pedicel, grooved on both surfaces, centrally hollowed out, the cavity communicating with the stomach. Sexes probably united. Stomach with a strong anterior gizzard. Lingual membrane broad, ovate, with three longitudinal series of teeth, the central dentated, lateral broad.

They live on foraminifera and small bivalves. The symmetrical, subventral position of the branchiæ, the posterior flow of water to them, and the resemblance of the foot to that of some bivalves, combined with the similar character of its action, appear in a striking manner to show its connexion with the Conchifera.-Clark, Ann. Nat. Hist. ser. 2. iv. 328.

M. Deshayes (Mém. Soc. Hist. Nat. Paris, 1828) regards the 
gills of Mr. Clark as part of the liver, and the salivary glands as the gills; and M. de Blainville has formed them into an order, under the name of Cirrhobranchia.

The animal is formed like the shell, round, and tapering gradually to the posterior extremity : it is smooth, whitish, and closely inrested with a thin pellucid membrane, beneath which two strong, satiny, ligamentous muscles are seen lying along the ventral surface, adhering closely, and each of them divided into a broad and narrow slip. The collar is very thick and fleshy, and makes a complete circle, through which the foot is pushed at pleasure. The foot forms the anterior portion of the body; it is cylindrical, thick, fleshy, pointed with a conical process, and cleft above; and in the groove we see the mouth in the shape of a compressed process, projecting forwards, and with its edge fringed with short tentacular papillæ. Johnston, Trans. Berw. Nat. Club, ii. 39.

They live buried in the sand or sandy mud in from ten to one hundred fathoms. The gills are pale green. The hinder termination of the shell, when perfect, is tapering, with a short notch on the dorsal or arched side of the shell; or if it is truncated, then it is furnished with a lateral, tubular projection, rather broadly fissured on the dorsal edges.

\section{Dentalium.}

Shell tubular, tapering, curved; apex truncated, with a simple perforation; aperture circular.

1. D.? semistriolatum, Linn. Trans. t, 115. f. 4; Chiaje, t. 115. f. 3.

When the apex of the shell is broken off, it is reproduced by a spurlike process on the edge.

\section{Entalis.}

Shell conical, elongate; apex truncated, with a longitudinal fissure on the dorsal or hinder margin; mouth circular.

1. E. vulgaris, t. 115 . f. 2 , t. 116 .

Central tooth of Entalis vulgaris subsemicircular, oblique, flat;

Fig. 90.-Teeth of Entalis vulgaris.

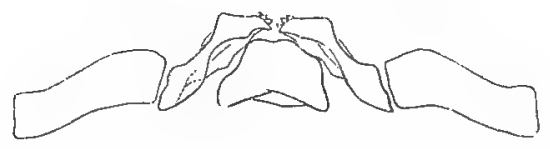

base somewhat straight; margin waving; cutting edge unarmed; lateral tooth with a compressed angular scape; hook with an inflexed, blunt angle; apical margin denticulated in front; limb with a large, bent, rhomboidal lamina, elongated (fig. 90).

The young have the apex of the shell slightly inflated, with a rather oblique oval aperture. The shell of the younger specimens is more arched near the top; the older specimens become trun- 
cated, and there is often a small, central, prominent tube, like an internal shell formed within the old one. This state has been called a species, Dentalium labiatum, Brown.

\section{Suborder V. Cervicobranchia.}

Gill single on the left side of the gill-cavity on the back of the neck. Shell conical, symmetrical. Teeth in a few longitudinal series, forming arched cross series of two or three pairs of teeth (p. 167).

\section{Fam. XI. TECTURID㞼.}

Teeth in six longitudinal series, the two inner close, uniform, the two lateral on each side in an oblique cross line, inner one often larger. Gill single, on the side of the back of the neck.

* Mantle edge bearded or simple, without any lamince on the inner surface near the margin.

\section{NAcella.}

Shell ovate, conical, thin; apex subanterior, near the front margin; mouth simple. Teeth in six longitudinal series and in arched cross series, the two inner close, the two others lower down and parallel to each other.

1. N. mytiloides.

\section{Tectura.}

Shell conical, convex; apex subanterior; margin even, simple. Gill one, placed on the left side of the head, prominent externally.

1. T. parva, t. 70. f. 7, t. $110^{*}$. f. 7 .

?2. T. tessellata, t. 70 . f. 6 .

3. T. testudinalis, t. 268. f. 2 (t. a. a. f. 2).

4. T. cassis, t. 114 . f. 8.

5. T. flammea, t. 114, f. 5.

6. T. fragilis, t. 114*. f. 7 .

7. T. striata, t. $114^{*}$. f. 6 .

8. T. stellaris, t. $114 *$. f. 4.

9. T. conica, t. $114^{*}$. f. 2 .

10. T. punctata, t. $114^{*}$. f. 3 .

11. T. —?, t. $110^{*}$. f. 9 .

12. T. zebrina, t. $70^{*}$. f. 7.

The arcuated branchial plume of Tectura parva issues from the back of the neck; in a state of quiescence it does not appear long, but can be greatly extended and contracted, like a pair of ladies' cross-barred forceps; it is composed of a pectinated leaf of almost 
horizontal, compact, rather short, blunt strands: the artery and branchial veiu are easily observed; the plume gradually curves and tapers from its origin to a pointed termination, and is of the palest uniform hyaline drab; it may often be seen exserted and vibrating like a tentaculum in all directions; the anus is under the plume.

The foot serves as a nidus for the membranous vesicular envelope when the young are expelled from the matrix, and when the embryos have left it is discharged, as in Ianthina.-Clark, Moll. 263.

Head of Tectura parva large, with a sharp edge in front and on the sides. Tentacles subulate. Eyes - ? ? Foot simple, without any lines. Mantle edge simple, under side smooth. Gill triangular, end free?

Fig. 91.-Teeth of Tectura parva.

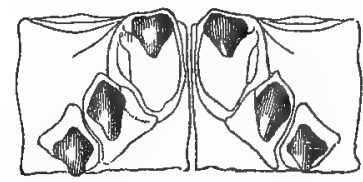

The teeth of Tectura parva are square, entire, in a diagonal series; tips conical (fig. 91).

The teeth of Tectura testudinalis are square, with the anterior outer angle retuse and produced; teeth two on each side, the anterior long, slender, furnished with a hook at the inner angle; posterior almost transverse, with a double cutting edge, the inner much the larger and subtriangular.

The mantle of Tectura scutum (Lottia punctata, Gray) is thin, with a rounded thickened edge, without any appearance of beards in the specimen preserved in spirits. Gills triangular, elongate, from the left side of the hinder.part of the gill-cavity, free the whole of its length, and formed of regular transverse laminæ united by a continuous margin on each side.

The lingual membrane of Tectura Wiltoni, from the Cape of Good Hope, is elongate, linear, dark brown, with a transverse paler line between each set of teeth. Teeth $3 \cdot 3$, brown; apex opake black, in oblique lines, conical, acute, curved ; the inner close together, curved forwards; the middle and outer lateral curved outwards; the outer lateral bifid, as if formed of two cones.

The teeth of Tectura apicina, also from the Cape of Good Hope, are similar in all respects to $T$. Wiltoni, but the middle lateral teeth are smaller and slenderer above; the two outer lateral are threelobed, the two apical lobes being nearly equal, and the one at the upper part of the base smaller.

The lingual membrane of T'ectura —— ?, from Magellan Straits, is elongate, linear, narrow, brown. Teeth $2 \cdot 2$, brown; apex conical, curved, claw-like, acute, opake black ; inner close together, with the hook bent outwards; apex when worn truncated; outer far apart, with the hook bent inwards towards the centre, when worn truncated.

The lingual membrane of Tecturu, no. 266, is linear, very narrow, 
transparent. Teeth $2 \cdot 2$, small, transparent; apex black, opake ; the

- inner close together, with elongated oblong roots and small rounded apices; the outer larger, with short broad oblong roots, and a transverse three-hooked crown.

The mantle of a Tectura (like T. testudinalis), from the Sandwich Islands, is thin-edged, narrow, thickened, rounded, with a series of minute rather close tubercles on the margin ; inner surface and sides of the body smooth, without any larainæ. Gills elongate, tapering;, acute, free the whole length, and prominent. Lingual membrane elongate, rather narrow. Teeth black, conic, curved, in alternate bands of two and four series; the intermediate ones with only two teeth much the largest.

The mantle of M. d'Orbigny's specimen of Patella Petrei, which is only a variety of Tectura zebrina, is simple, with a series of rather distant, subcylindrical, fleshy beards, placed in a regular raised line a little within the edge of the under side, continued over the head. Gills small, elongate, simple, tapering to a fine point in front, arising from the hinder part of the left side of the mantle-cavity, and free the greater part of its length, formed of close-set regular transverse laminæ, edged on each side by a fleshy band. Vent and aperture of generation each prominent on separate tubercles on the right side of the base of the mantle-cavity. Eyes very small, lateral, exterior. Tentacles subulate. Foot quite simple and smooth on the sides. Rostrum broad; mouth oblong, transverse; lips discoid, slightly fringed.

In the same bottle was a small specimen of the Patella zebrina of D'Orbigny, with exactly the same animal, but it was soft, from the weakness of the spirit, and the submarginal beards were not so distinctly developed.

The delicate brittle Tectura (Patelloida) depicta, which lives on the surface of Zosteras at San Diego, California, is almost linear, being compressed at the sides, and at least four times as long as wide. -Hinds, Voy. Sulph. 35.

** Mantle with a series of lamina just within the edge beneath.

\section{Scurria.}

The mantle the size of the shell, simple, on the edge with a series of half-oblong rather distant fleshy laminæ just within the edge, continued over the head and behind. Foot oblong, smooth, and without any appendages on the sides. Tentacles subulate. Eyes on the outer side of the swelling at their base. Rostrum short; mouth oblong, transverse; lip finely striated. Gill elongate, tapering, on the left side of the gill-cavity over the back of the head; the end free, floating, formed of very numerous, close, transverse laminæ, with a large transparent vessel on the left margin. Tongue-membrane linear. Teeth yellow, $3 \cdot 3$ ?

Lives in holes in the roots of Fuci, like the Patina carulea, D'Orb.

1. S. mitra, t. 114. f. 1 .

The gill of Scurria mitra is triangular, on the left side of the back. 
Inner side of the mantle edge quite distinct from the gills of other Patella, with a series of transverse waved membranous laminæ, continued round the edge over the head. Foot simple.

\section{Fam. XII. GADINIAD庄.}

Gill single, placed obliquely across the back of the neck. Tentacula expanded, forming a funnel-shaped expansion. Eyes sessile. Shell conical; muscular impression horseshoe-shaped, marginal, with a groove (for the vent) in the front of the right side of the scar. Teeth - ?

\section{Gadinia.}

1. G. Garnoti, Wiegmann, Arch. 1839, t.3.f. 3; Adams, Gen.Moll. t. . f. 4 .

\section{Fam. XIII. LEPETID丑.}

Tooth : central single, with two hook-like teeth on each side. Gills none? or two pinnate on the back of the neck?

\section{LEPETA.}

Eyes none.

1. L. cæca, Müller, t. . Propilidium ancyloide, Forbes, t. 268. f. 4 (t. a. a. f. 4$)$.

The teeth of Lepeta caca are square, subquadrate, anteriorly rounded and winged; central tooth at the base widely cordate, cutting edge three-lobed, middle lobe longer, subspatulate, side lobes shorter, kidney-shaped; lateral teeth two on each side, laminaceous, shortly hooked, the inner one winged on the outside and produced behind into a style (fig. 92).

Fig. 92.-Teeth of Lepeta cceca.

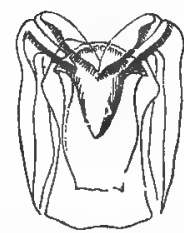

The edge of the foot of Lepeta Franklini is quite simple, without any fringe. Mantle edge simple, with a small thickened ridge on the under side near the margin. Gills __? Tentacles far apart, setaceous. Eyes none in specimen in spirits.

\section{Iothia.}

Gill none round the foot.

1. Iothia fulva. Patella fulva, Müller, t. 70. f. 5. Pilidium fulrum, Forbes, t. 268. f. 3 (t. a. a. f. 3).

The teeth of Iothia fulva are square, elongate, in front angularly winged on each side; central tooth elougated at the base, cutting 
edge entire, strong, arrow-shaped, the middle point strong, with a minute basal one on each side; lateral teeth elongated, hooked; hook long, lanceolate, outer margin ciliated.

\section{Suborder VI. Cyclobranchia.}

Gill lamellar, on the inner surface of the mantle, forming a more or less complete ring just beneath the margin. Side of foot with a sunken groove. Shell conical, symmetrical. Teeth in ten or eleven longitudinal series; the two inner close together, the three lateral series close and lower down, forming an arched or double cross series (p. 169).

Fam. XIV. PATELLID

Shell simple, conical; apex subanterior. Aperture ovate or oblong. The gills are only an elongated branchial plume springing from the neck, and ought not to be looked on as a pair of symmetrical subsemicircular laminæ, as in the Cyclobranchiate Chitons.

M. Cuvier and most other naturalists consider the laminæ placed round the edge of the under side of the mantle as gills, but M. de Blainville doubts this being the case, and considers some vessels which he has observed on the inner surface of the mantle over the back of the neck as the true gills of these animals, and he has accordingly formed them into a family under the name of Retifera.

I have not been able to observe any peculiar vascular structure in the part indicated; and as the laminæ round the edge of the mantle exactly agree in texture with the laminæe similarly disposed in Phyllidia and Chiton, which M. de Blainville considers as gills, I have little doubt but that the latter are true gills.

According to M. Rang, they seldom change their place on the rock, and then only in the night.

These animals are very abundant on the rocks, and our English species is much sought after for food and as bait by the fishermen and others who live on the coast: and the large species which are so abundant at the Cape of Good Hope are collected by the English soldiers and by the Hottentots to make soup of.

Adanson speaks of the beauty and delicacy of form of the fringe of tentacula which surrounds the edge of the margin of the mantle of the animal of this genus. In the species which he mentioned there were three rows of them, each containing above 200 tentacula.

Adanson observed some minute globes on the surface of the foot of one of the species of this genus, which he believed to answer as a sucker to attach the animal to the rocks (Senegal, p. 30). 
1. Patella.

Gill continued over the head of the animal.

1. P. compressa, t. 70. f. 1 .

2. P. granularis, t. 70. f. 2 .

3. P. scutellaris, t. 70. f. 3.

4. P. cærulea, t. 70. f. 8.

5. P. vulgata, t. 70. f. 10, t. $70^{*}$. f. 1, 2?, 6?, t. $110^{*}$.f. 1-8; Forbes \& Hanley, B. M. t. C.C. f. 1 .

6. P. pyramidata, t. $70 \%$. f. 3 .

7. P. crenata, t. 110 . f. 2 .

8. P. Howei, t. 110 . f. 1 .

9. P. Testudo.

Central teeth of Patella vulgata on each side three, two of which are equal and linear, the base elongated, flat, behind produced on the inside, winged on the outside, longer, tip recurved, with a claw-like hook, simple, keeled, black; the third, posterior, wider, at the base rounded and produced on the outside, with an oblique recurved cutting edge, armed with three divaricating teeth ; teeth of lateral series linear, flat, with a very short hook (fig. 93).See Osler, Phil. Trans. 1832, t. 14.

How some Patella vulgata exist is a mystery ; they are often fixed for months, perhaps

Fig. 93.

Teeth of Patella vulgata.

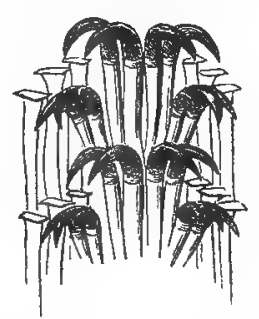
years, on rocks, at altitudes where they can rarely, if at all, be aspersed by the sea, and are debarred access to marine vegetables; their recorded descents from high levels, and periodical exits from, and returns to, the identical hollows they have made, after feeding on algæ, have almost a fabulous complexion; zones of sand fifty yards wide often intervene between them and such food, and their exceedingly slow locomotion is opposed to such manourres.-Clark, Moll. 261 .

The gills of Patella vulgata form a continued row within the margin of the mantle, but interrupted on the right side, where the blood enters the gills. The foot is divided longitudinally into two equal parts, the milt and eggs occupying the right side of the foot. They often move from place to place, as may be observed by the trail they leave in the slight coating of mud left on the rocks by the water as the tide falls. The younger animals appear to be most active. When attached to soft rocks, as chalk, it forms a cavity which is divided into two divisions by a cross ridge; the hinder division is the deepest, and there is no lunate ridge, as is formed by the animal of the genus Hipponyx (Fool's-cap).

The mantle of $\boldsymbol{P}$ atella with black rays, from the Sandwich Islands, is simple, with a crowded series of laminæ on the under side of the mantle near the union with the foot, interrupted over the head. 
Lingual membrane very narrow. Teeth in arched cross series, blacktipped.

Head, tentacles, sides of feet and edge of mantle of Patella compressa deep violet-blue; foot violet-grey; gill yellow. Cape of Good Hope, living on the stems of Fuci (not seen on the shores).

The Messrs. Adams have formed a subgenus, Cymbula, for Patella compressa, which is only a variety of form, produced by the situation where it lives, of Patella miniata, arranged by them with the true Patella. Specimens with the two species combined in the same individual are not very rare. The subgenus Scutellastera of the same anthors, I fear, is not more distinct.

The edge of the mantle of Patella oculus is deeply lobed, substellate like the shell.

The edge of the mantle of Patella testudinaria is fringed with a series of minute tentacula.

The gills of Patella Testudo are, like those of P. vulgata, united over the head.

Patella insessa, with a small horny brown shell with three or four white markings on the apex, is always found imbedded in the fronds of a Laminaria at California, often so deeply that it must be cut out with a knife.-Hinds, Voy. Sulph. 53.

\section{Olana.}

Shell ovate, depressed, narrowed and produced in front; apex obtuse, subcentral ; aperture broad, narrowed in front. Foot ovate. Head rather produced. Tentacula short. Mantle much produced and attenuated in front. Gills not interrupted over the head. Mus. Paris.

1. O. cochlear.

** Gills interrupted over the head.

\section{Patina.}

Gills interrupted over the head. Shell oblong, smooth, pearly within; aperture simple.

1. P. cærulea, t. 70. f. 4, t. 268 . f. 1.

They live imbedded in holes they form in the roots of the larger Fuci or Laminaria, or on the frond; when in the former situation, they are thick, with a curved base; when in the latter, thin and flatbased.

Central teeth of Patina pellucida on each side three, of which two are nearly equal, elongated at the base, flat, jointed in the middle, behind within curved and produced; the inner one more slender, linear, with the tip claw-like, hooked, the outer one broadish ; outer margin produced in front, tip wide, subtriangular, hooked; the third, posterior, somewhat rectangular, furnished with an oblique cutting 
edge, flat and bluntly trifid; teeth of lateral series three, shortly hooked (fig. 94).

Fig. 94.-Teeth of Patina pellucida.

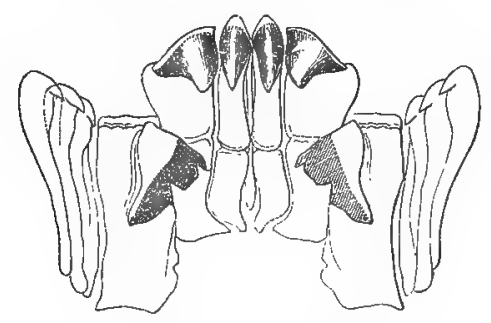

The sides of the foot of Patina pellucida are furnished with a slight lobulated fringe edging the upper margin. The edge of the mantle with a series of minute tentacles, just within which are placed the series of gills formed of close, large, triangular transverse leaves; the series is interrupted over the head; the mouth edged with expanded lips. The tentacles are far apart, with the eyes at their outer base. The mantle with 50 to 65 equidistant, slender, acute, tentacular filaments: floating beyond the edge between its margin and the body is placed the branchial cordon of 80 to 100 subtriangular plates, so extremely close-set as to present the appearance of thread-like filaments without depth, diminishing gradually anteally until they are interrupted by the head.-Clark, Moll. 258.

\section{Helcion.}

Shell half-ovate, radiately ribbed; apex submarginal, anterior; aperture ovate; edge crenated. Gill interrupted over the head, of small and filiform strands.

1. H. pectinatus.

\section{Suborder VII. Polyplacophora.}

Gills in two lamellar series, one on each side of the hinder part of the body under the mantle edge. Shells 8 , forming a linear imbricate series on the middle of the back. Lingual membrane long, linear; central series with many teeth, middle one unlike the rest, outer lateral one on each side very large, with a black opake hook; lateral teeth several, forming jointed unarmed lamellæ; one erect, hooked (p. 173). 
Fam. XV. CHITONID $A$.

Shells of 8 valves, forming an imbricate series on the middle of the back. Valves with a more or less wide plate of insertion sunken into the mantle, with a deep lateral notch on each side; the anterior and posterior valves often with other notches on the terminal edges. Gills conic, lamellar, in two series, one on each side the hinder part of the body.

Many anatomists have proposed to separate these animals from the Mollusea, by forming them into a distinct subclass, and have considered them more nearly allied to the Annelides !; but I cannot see the slightest grounds for such a separation; and the observation of the development from the eggs by Lovén has entirely disproved any affinity to them. They chiefly differ from other Mollusca in the shells not being developed on the embryo until some time after they are hatched.

The eggs are loosely united in clusters, on stones. Each egg is enclosed in a thick, vesicular, folded envelope. The embryo in the egg is oval (fig. $95 a$ ), without any trace of shell, divided by a circular indentation into two nearly equal parts, close to which are attached the cirri, by means of which the movements of the embryo are effected. In the middle of the upper part there is a tuft of very fine filaments which scarcely exhibit any movement. The lower half has two dark points (eyes), one on each side close to the indentation.

The young, when hatched, swim round the cluster of eggs, and are more elongated ; the front part is finely ciliated, and the anterior tuft of filaments occasionally vibrates; the hinder part extends more rapidly, and becomes conic (figs, $b \& c$ ). The back is marked with seven cross furrows; between these the first rudiments of the shell. make their appearance in the form of close granulations. The animal bends frequently, is quite soft, can only swim, but soon after this begins to crawl (fig. c), and by a circular indentation the mantle is separated from the foot. The eyes are seen more distinctly to be situated on the ventral side, and are indistinctly visible from above (fig. $d$ ).

The front portion of the animal is sprinkled with acute tubercles, principally on the upper surface. There is no trace of the mouth. The furrows of the mantle become more distinctly separated, and its margin more closely set with acute tubercles. The first shell appears in the form of narrow bands with irregular margins; they are seven in number; the three or four anterior are equal in breadth; the hinder diminish rapidly. The anterior filaments disappear.

The animal sometimes swims and sometimes crawls (figs. $d \& e$ ). The front portion developes into the head, haring a mouth, with curved folds in front. The eyes are situated on the sides on distinct protuberances, and consist of pigment spots and lenses (fig.e). The foot has not yet assumed its full size. The gills are not yet visible. 
The mantle advances over the head. The front shelly valve has advanced over the eye (fig. $f$ ). The flat tuberculated surface in front of the valves is gradually diminished, and the eighth valve is produced behind the seventh.

Fig. 95.-Development of (Chiton) Leptochiton cinereus : after Lovén.
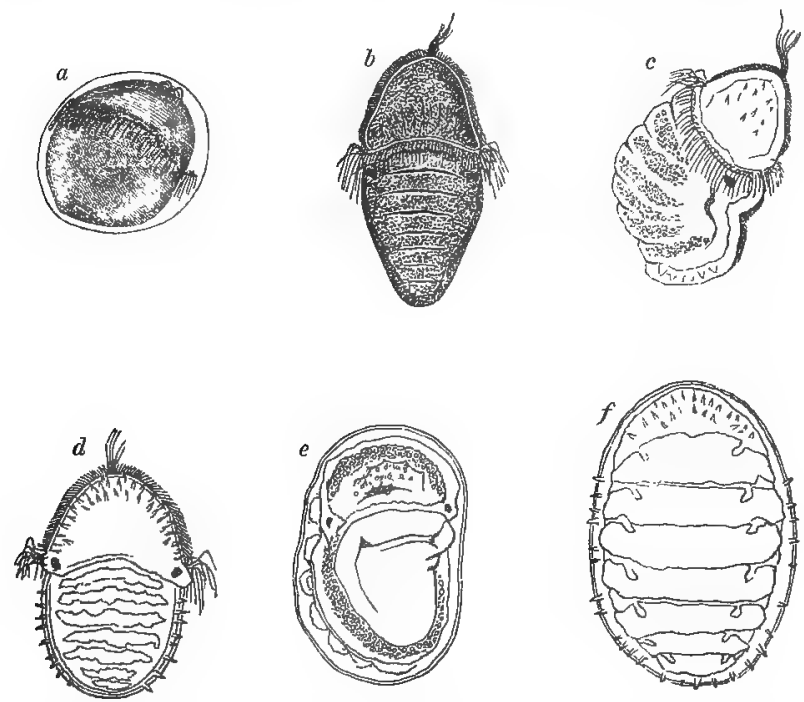

a. Embryo in the egg.

b. Dorsal view of young Chiton, showing the commencement of the divisions.

c. Lateral view of the same.

$d$. Dorsal view of young Chiton further advanced, with the seven irregular valves deposited in the segments.

$e$. The same from beneath, showing the foot, with the eyes on the side of the head.

$f$. Dorsal view of a still older Chiton, showing the diminished tubercular front portion.

The valves are at first short, with an irregular wavy outline, but they increase in thickness and size by the addition of layers on the under surface; and as they increase, two deep notches are formed in the front of the outer sides, which are well marked in the adult shells (fig. $f$ ).

Loven regards the circle of cirri as analogous to the cirri on the veil of the young of other Gasteropods and Acephala, but in Chiton the veil is not developed into a broad extensile sail, and he compares the anterior portion, having the tuft of filaments, to the pearshaped body which usually carries the flagellum in the marine Ace- 
phala. The veil is often absent in other Mollusca, or only appears as oral or labial tentacles.

The valves are not formed by four united joints; and still less do they support the opinion that the hinder valve is the true shell, analogous to Patella, and the anterior valves supplementary on it.

It has been the habit of conchologists to keep the valves of this genus attached to the dry mantle of the animal, and to regard them as a single shell; but it should be recollected that the separate valves are the analogues of the only parts of the molluscous animals which are usually kept in cabinets and studied by conchologists.

It has been objected that the character derived from the form of the plate of insertion of the valves can only be seen by the destruction of the specimens as they are usually kept in cabinets, but they can generally be seen from the under side, or through the substance of the mantle; when this is not the case, the form of the plate of insertion can be easily developed by paring away the under surface of the mantle, so as to show part of the edge of the valves, without injury to the specimen; and they may be easily made more visible throngh the inner side of the mantle by being soaked for a few hours in a weak solution of caustic potash; but care should be taken that the specimen is not left too long in soak, nor the solution be too strong, otherwise the margin will be dissolved.

The form of the plate of insertion may also be easily predicted by inspecting the inner surface of the valves, for the notches in the margin leave an impressed line from the vertex of the valve, as they are gradually filled up by the growth of the valve.

The valves are best separated from the coriaceous skin of the body, called the mantle, by soaking them in a strong solution of caustic potash; as then the plates of insertion are cleaned, and not broken, which they are likely to be if they are taken by force from the mantle.

The number of notches in the plates of insertion is sometimes, but very rarely, liable to variation. In one specimen of Chiton Bowenii in the Museum Collection, the plate of insertion of the last valve but one has two notches on one side, but the normal single notch of the genus on the other.

"A Chiton has a carapace like an isopod Crustacean, a dorsal vessel like an Annelid, bilateral symmetrical reproductive viscera like an acephalous Mollusk, a head and foot like a patelloid Gasteropod, a posterior anus like the Fissurellide, and branchiæ like those of the brachyurous Crustacea! Such manifold affinities at once unite and sever this odd group from several most dissimilar classes." $-D r . T$. Williams, Ann. \& Mag. Nat. Hist. xvi. 408 (1855):- 
A. Mantles without any pores, furnished with fascicles of bristles or spines on the sides.

a. The exposed part of the valves broad, band-like, transverse, closely imbricate one on the other. The plates of insertion moderate, of the anterior and the posterior valve divided into several lobes more or less pectinated on the edge.

* Margin covered with uniform scales, entire behind.

\section{Chiton.}

Margin covered with regularly disposed, imbricate, smooth, polished scales; valves thick; the plates of insertion pectinately lobed, of the central valve with a single subcentral notch, of the hinder valve broad, distinctly lobed and pectinated; the hinder valve entire; apex superior, subcentral (fig. 96). The gill occupying nearly the whole length of the sides of the foot.

+ Scales of the margin moderatesized.

1. Ch. striatus, Sow. Ill.f. 3, 41 . Chiloe.

2. Ch. Cumingï, Sow. Ill. f. 32 , 51. Chili.

3. Ch. albolineatus, Sow. Ill. f. 39. Mexico.

4. Ch. squamosus. West Indies.

5. Ch. sulcatus, Sow. Ill. f. 12.

6. Ch. granosus. Chili.

7. Ch. glaucus.

8. Ch. granulosus. Conception.

9. Ch. Siculus.

10. Ch. liratus, Sow. Ill. f. 126.

11. Ch. foveolatus, Sow. $\pi l$. f. 60 .

12. Ch.excavatus, Sow.Ill.f. 131 .

13. Ch. fasciatus, Sow. Ill.f. 153.

14. Ch. australis, Sow. Ill. f. 46.

15. Ch. Stokesii, Sow. Ill. f. 24.

16. Ch. virgulatus, Sow.Ill.f. 132.

17. Ch. patulus, Sow. Ill. f. 134.

18. Ch. marmoratus, Sow. Ill. f. 148 .

19. Ch. articulatus, Sow.Ill.f. 18.

20. Ch. læevigatus, Sow.Ill.f. 18*.

Fig. 96.-Valves of Chiton olivaceus.
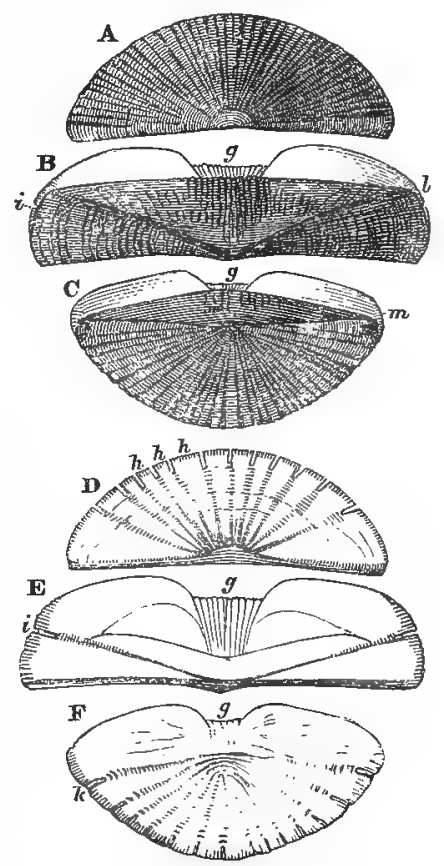

A, anterior, B, middle, and C, terminal valves. $\mathrm{D}, \mathrm{E}, \mathrm{F}$, inner surface of same valves. $g$, the small lobes in the middle of the anterior margin between the wings. $h, i, \& k$, notches in margin of insertion. $l \& m$, confines of central area. 
22. Ch. Inca, t. 208 . f. 2 .

23. Ch. pellis serpentis, t. 189. f. 6, t. 208. f. 6 .

24. Ch. ? ?, t. 209. f. 1 .

25. Ch. ? ?, t. 209. f. 3 .

26. Ch. Tehuelcha, t. 207. f. 3 .

27. Ch. Isabella, t. 207. f. 1 .

28. Ch.? Islandica, t. 154. f. 5 .

\section{t十 Scales of the mantle small.}

29. Ch. Bowenii, Sow. Ill. f. 37. Magellan Straits.

\section{Enoplochiton.}

Mantle covered with oblong, unequal, elongated scales; valves broad, exposed, thick; lateral area distinct; plate of insertion of anterior valve lobed, of middle valve with a central nick, of the hinder valve entire, rounded; the hinder valve with a produced terminal apex. The valves become much eroded (fig. 97).

1. E. niger. Coquimbo.

\section{Radsta.}

Margin covered with regularly disposed imbricated smooth scales; margins of insertion of the central valves pectinately divided, and each furnished with two notches, of anterior and hinder valve broad, lobed and pectinated; posterior valve entire ; apex superior, subcentral.

1. R. Barnesii. Coquimbo.

\section{Callochiton,}

Margin covered with imbricate scales; the valves keeled, the plates of insertion rather short, thick; of the terminal valves divided into many, and of the central valves into four bifid lobes; the hinder valve entire. Gills on hinder half of the foot.

+ Margin with lanceolate, elongate, erect, closely pressed scales.

1. C. lævis, Zool. Journ. v. t. 5. f. 1.

+† Margin with ovate, imbricate scales.

2. C. evanidus, Sow. Ill. f. 139.

Fig. 97.-Valves of Enoplochiton niger.
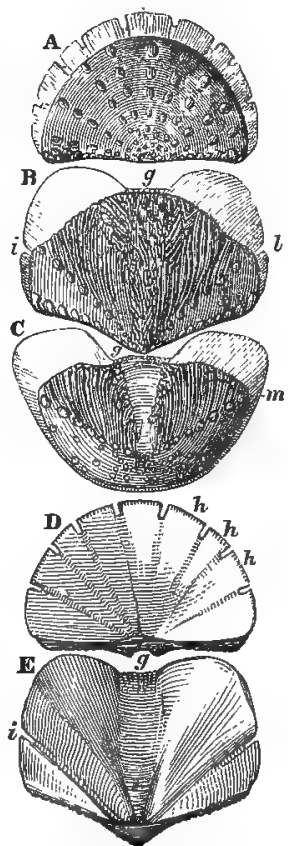

$A$, anterior valve; $D$, inner surface. $B$, middle valve; $\mathrm{E}$, inner surface. $\mathrm{C}$, terminal valve. $g$, antero-central area. $h \& i$, notches in margin of insertion. $l \&$ $m$, confines of central area.

3. C. fuliginatus, A. Adams, Gen. Moll. t. 53. f. 2. 
Central tooth of Callochiton lavis linear, somewhat narrower in the middle, cutting edge transverse, smoothish, convex above; first side one scarcely larger, like a broad turned claw; second very large, with a subclavate scape, hollowed on the outside, hook minute, wide, three-toothed; lateral teeth 5, irregular, trapezoid, sixth erect, between the second and third, subtriangular; upper margin widely reflexed, striolated.

\section{IschNOCHITON.}

Margin covered with very small imbricate scales; valves thin; the plates of insertion very thin, smooth-edged, of the central valves each with a single notch; posterior valve entire. Gills nearly as long as the side of the foot.

+ Scales of the mantle transversely grooved.

1. I. textilis.

2. I. limaciformis, A. Adams, Gen. Moll, t. 53. f. 3. West Indies.

3. I. Magdaliensis.

4. I. altus. Philippines.

+† Scales of the mantle minute, granular.

5. I. marginatus, Zool. Journ. จ. t. 5.

\section{LEPTOCHITON.}

Margin covered with granular scales, with a series of spines on the edge; valves rounded, thin; the plates of insertion rudimentary, without any notches either in the terminal or central valves; the hinder valve entire. Gill short, on the hinder part of the side of the foot.

1. L. cinereus.

2. I. Cajetanus.

3. L. asellus, A. Adams, Gen. Moll. t. 53. f. 4.

Central tooth of Leptochiton cinereus elongated, base oval, neck slender, cutting edge transverse, wider, smoothish, convex above ; first

Fig. 98.-Teeth of Leptochiton cinereus.

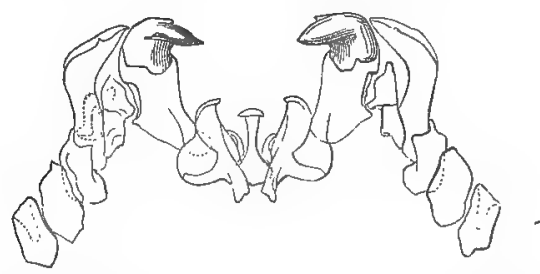

lateral somewhat larger, slightly hooked, furnished on each side with a large rounded wing, in the dorsal cavity recciving the produced base of the second largest tooth; scape thick, notched outside ; hook black, 
opake at the bend, with a spine in front; lateral teeth 5 on each side, of irregular shape, trapezoid, arranged obliquely, the sixth erect between the second and third, hooked, slightly bent, upper margin reflexed and cut (fig. 98).

Mr. Clark, who has very imperfectly observed the development of this species, erroneously says it shows no metamorphosis.

\section{** Mantle covered with imbricate scales, slit behind.}

\section{Lorica.}

Mantle very densely covered with small smooth ovate imbricate scales, the hinder edge slit; valves broad, transverse; plates of insertion of the front few-lobed, of the hinder deeply emarginate and obsoletely lobed; the hinder valve with a produced acute posterior marginal apex, and notched on its hinder edge. Gills - ?

1. L. Cimolia, Adams, Gen. Moll. t. 54. f. 5, shell only.

\section{Schizochiton.}

Mantle broad, deeply notched behind, covered with small chafflike scales; valves elongate, subcordate, narrow; lateral area short, distinctly defined; the hinder valve large, with a subposterior superior apex, and a deep notch on its hinder lower edge, and the plate of insertion small, with a few oblique notches, scarcely pectinated. Gills occupying the hinder half of the side of the foot.

1. S. incisus, Adams, Gen. Moll. t. 55. f. 6. Philippines.

\section{*** Margin covered with uniform calcareous thiek bristles like spines, entire behind.}

\section{Acanthopleura.}

Margin covered with elongate shelly bristles; valves thin, broad, close, keeled; lateral area distinct; plates of insertion pectinated, of the central valves with a single lobe on each side, of the hinder valve regular, well developed; last valve entire.

1. A. Peruviana, Sow. Ill. f. 44. Peru.

2. A. bicolor. West Indies.

3. A. Hennahi, Sow. Ill. f. 33.

4. A. Watsonii, Sow. Ill. f. $81,82,130$.

5. A. Hanleyi.

\section{Mavgeria.}

Margin covered with elongate shelly spines or bristles; valves broad, thick, close; lateral area rather indistinct; plates of insertion pectinated, of central valves with a single notch on each valve, of hinder valve narrow, rather irregular. Gills as long as the sides of the foot. 
+ Margin bristly; lateral area of valves distinct.

1. M. nobilis. New Zealand.

+† Margin spinose or spinulose; lateral area of valves rather indistinct.

2. M. picea, Sow. Ill. f. 147. West Indies.

3. M. spinigera, Sow. Ill. f. 68. Peru.

4. M. Owenii. Gambia.

5. M. spinosa, Sow. Ill. f. 151. Australia.

6. M. brevispinosa, A. Adams, Gen. Moll.t. 54.f. 1; Sow.Ill.f. 136. Island of Johanna.

7. M. magnifica, Sow. Ill. f. 52.

\section{Corephium.}

Mantle with shelly spines; valves broad, exposed; plates of insertion of the anterior valve lobed and pectinated, of central valves with a single nick, of hinder valve distinct, slightly denticulated, with one small central slit, not lobed on the sides; hinder valve oblong, with a subcentral, subposterior, not produced apex.

1. C. echinatum, Sow. Ill. f. 47 .

2. C. —?, Cuvier, t. 154. f. 6 .

3. C.? asellus, Forbes \& Hanley, t. A.A. f. 5.

4. C.? rubrum, Forbes \& Hanley, t. A.A. f. 6.

\section{ONYthochiton.}

Mantle covered with shelly spines, bristles or chaff-like scales; valves broad, exposed, thick; plates of insertion of anterior valve lobed, of middle valves one-nicked on each side, of the hinder valve rounded, entire; posterior valve with a produced terminal apex.

1. O. Gaimardi.

2. O. hirtosus.

3. O. undulatus. Van Diemen's Land.

\section{Molpalia.}

Mantle moderately broad, spinulose; front edge often expanded and produced, narrow behind (and slightly notched?) ; exposed part of the valves broad, transverse, depressed; plates of insertion moderate, of the front valve lobed, pectinate, of the hinder valve expanded like those of the lateral valve, and two-lobed; the hinder valve with a rounded lobe on the hinder edge.

+ Mantle moderately wide in front.

1. M. Hindsii, A. Adams, Gen. Moll. t. 54. f. 7.

2. M. Simpsoni.

3. M. Blainvillii.

†† Mantle very wide, expanded in frout. 
**** Margin bald, smooth, covered with a hard shining skin beneath, entive behind.

\section{Tonicia.}

Margin naked, smooth; valves broad, transverse, keeled, close together; margin of insertion pectinately toothed, of central valves with a notch on each side. Gills occupying the greater part of the sides.

1. T. atrata, Sow. Ill. f. 57, 58. Falkland Islands.

2. T. elegans, A. Adams, Gen.Moll. t. 53, f. 5 ; Sow. Ill. f. $73,74$. Conception Bay.

3. T. rubra.

4. T. fulva, Sow. IIl. f. 53. Cadiz.

5. T. lineata, Sow. Ill. f. 77.

6. T. Swainsonii, Sow. Ill. f. 5. Peru.

7. T. cerasina.

8. T. lævigata.

9. T. lyrata.

10. T. Grayii, Sow. Ill. f. 8, 16.

11. T. castanea, Sow. Ill. f. 114, 115, 116. Cape of Good Hope.

12. T. fastigiata, Sow. Ill. f. 11 . California.

\section{Fannyia.}

Mantle broad, smooth; valves moderate, subcordate, rounded and far apart on the sides; lobes of insertion wide, denticulated, of the central valve with a single lobe on each side.

1. F. dispuncta, Zool. Journ. t. 77. f. 5.

This genus forms a passage to the genera which have only a small part of the valves exposed.

b. The exposed part of the valves small; the plate of insertion very broad, of the anterior valve divided by deep grooves into several lobes.

\section{Katharina.}

Body convex. Mantle smooth, naked; exposed part of the valves small, cordate; plates of insertion very broad, large; of the anterior valve divided into several deep grooves above, and slit on the edge; of the last three-lobed. Gills on each side of the foot.

1. K. tunicata, Middend. Ross. Chit. t. 10. f. 1, 2.

2. K. Douglasiæ.

c. The valves entirely covered by the mantle, appearing only to consist of the plates of insertion; the front part of the front valves five-lobed.

\section{Cryptochiton.}

Mantles covered with numerops close, uniform tufts of calcareous 
spicula; valves entirely hidden, consisting wholly of the plate of insertion; anterior valve divided into five pectinated lobes. Gills extending the whole length of the side.

1. C. amiculatus.

2. C. Stelleri, Middend. Mal. Ross.t. 1.f. 1, 2 ; Adams, Gen. Moll. t. 55. f. 1 .

Central teeth of Cryptochiton Stelleri (see Middend. Malac. Ross. i. 141.t. 3. f. $10,11,12$, t. 5. f. 9) small, squarish; inner lateral elongate, erect, curved, linear, three-toothed at the tip; the others flat, four-sided, elongate; inner smaller, gradually larger towards the outer series, which are largest, transverse, obscurely toothed on the front edge.

B. The mantle with nine pores on each side, the two front on the front margin of the anterior valves, and each of the others at the hinder edge of the side of each valve, all furnished with a tuft of spicula or bristles.

a. Mantle bald, spinulose beneath, the pores of the mantle furnished with subulate fexible bristles; the exposed part of the valves broad.

\section{Plaxiphora.}

Mantle with scattered tufts of bristles, and with a series of nime tufts of larger bristles on each side; valves broad, exposed, thin; the plate of insertion of anterior valve lobed, of middle valve with a notch on each side, of the hinder valve entire, smooth, rounded; the hinder valves with a produced subposterior apex.

1. Pl. Carmichaeli = Chiton albidus, Ch. raripilosus, Ch. costatus, Blainv., Ch. biramosus, Quoy, Ch. setiger, Ch. Fremblii, and Ch. setosus, Sow. Terra del Fuego.

b. Mantle spinulose, with the pores furnished with tufts of bristlelike calcareous spines; exposed part of valves moderately large.

\section{Hanleya.}

Body depressed. Mantle spinulose; lateral tufts of spines small; exposed part of valve broader than long; margin of insertion of the valves entire, of anterior and posterior valves very narrow.

1. H. debilis = Chiton Manleyi, Thorpe.

\section{Acanthochetes.}

Body oblong elongate, rather depressed. Mantle spinulose, tuft of spines generally large, often iridescent; exposed part of valves moderately broad cordate, as long as broad. Gills occupying twothirds of the hinder part of the sides of the foot. 
1. A. fascicularis, t. 154 . f. 2 , t. 207. f. 6, t. 209. f. 2.

2. A. Garnotii, t. 207 . f. 5.

3. A. polychetus.

4. A. roseus.

5. A. Lesueurii.

6. A. scaber.

7. A. violaceus, t. 208 . f. 3 .

8. A. hastatus.

9. A. hirundiniformis.

10. A. strigatus.

11. A. Zelandicus, t. 207. f. 2 .

12. A. — ?, t. 154. f. 4 .

M. de Blainville observes, that the valves of this genus are always without any trace of the lateral area (Dict. Sci. Nat. xxxvi. 537), but this must have arisen from his having only examined worn specimens.

\section{Chitonellus.}

Body elongate, subcylindrical, back convex. Mantle covered with short crowded calcareous spines, and the lateral pores small, with short crowded calcareous spines; exposed part of the front valve oblong, square, broad, often worn, of the hinder ones narrow, lanceolate; the plates of insertion large, of first valve bilobed, of lateral and hinder valves produced in front and scarcely notched on either side. Gills occupying about one-third of the hinder side of the foot.

1. Ch. fasciatus, t. 208. f. 5 .

2. Ch. larviformis, t. 208. f. 4.

3. Ch. lævis.

4. Ch. striatus.

Lingual membrane of Chitonellus linear. Central tooth linear;

Fig. 99.-Teeth of Chitonellus from Tasmania.

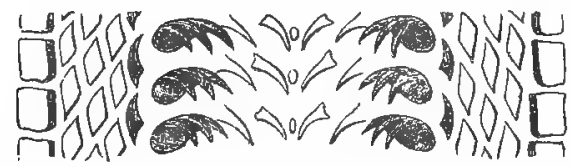

inner lateral small, linear, twice as long as broad, diverging; outer lateral large, with a large black convex apex, with three teeth on the inner edge; no external lateral teeth (fig. 99).

c. Mantle covered with furfuraceous scales, the pores with tufts of hair-like spines; exposed part of the valve small, broad.

22. Amicula.

Body ovate, ronvex; back convex. Mantle covered with furfurnccous scales; the pores with a tuft of yellowish hair-like spines; 
exposed part of the valves small, subcordate, as broad as long. Gills

1. A. vestita, Adams, Gen. Moll. t. 55. f. 2.

"The valves of Chitonellus Emersonianus are covered with a thin membrane coated with a dirty scurfy epidermis, which is easily rubbed off. Margin broad, thick, resembling macerated calf-skin, coated like the rest of the surface, and having two ranges of small tufts of yellowish hairs, two on each of the intermediate, and six or eight around the terminal valves."-Gould, Moll. Mass. 152. f. 19.

d. The mantle smooth; pores with a tuft of small spines; exposed part of valves very small, linear.

\section{Cryptoconchus.}

Body oblong, rather convex. Mantle smooth; back flattish or concave in the centre; the pores on the upper part of the sides of the back, each containing a tuft of short spicula; exposed part of the valves linear, much longer than broad, the plate of insertion of the front valve slightly crenated in front. Gills on the hinder half of the sides of the foot.

1. C. porosus, t. 207. f. 4, t. 208 . f. 1 .

\section{$A P P E N D I X$ to Scutimanchiata.}

At page 136, before Suborder I. Scutibranchia, $a d d-$

Suborder I*. Pseudobranchia.

Gills in form of branched vessel on the inner surface of the mantle. Body and shell spiral. The lateral central teeth large, irregular. Operculum none. Terrestrial.

These differ from Pulmonata in the mantle being free from the nape, leaving the pulmonary cavity open, and in the animal being unisexual. They differ from Phaneropneumona (p. 78), with which they have hitherto been united, in the teeth being truly Riphidoglossal.

Fam. I*. PROSERPINAD A (Erase from p. 86).

Muzzle short, annulated. Tentacles lateral, subulate, short, distant. Eyes sessile, on the outer side of the base of the tentacles; sides simple, without any membranaceous fringe or lateral beards. The lateral central teeth large, irregular, lobed or dentated. Foot moderate, truncated in front, acute and keeled above behind, with a concavity in the front part for the base of the shell, lined with an extension of the mantle. Operculum none. Shell spiral, depressed; 
whorls close-pressed, more or less covered with a polished coat; aperture lunate, with a fold forming a slight truncate canal at the columnar angle. Peristome simple, acute; throat and inner lip with spiral laminæ; axis covered with a callous deposit; the septa between the upper whorls absorbed.

\section{Proserpina (see p. 86).}

Shell polished all over. (Mantle expanded and reflexed over the upper and under part of the shell ?)

1. P. nitida.

\section{Ceres.}

Shell rugose and covered with a periostraca above, smooth and polished and covered with a thin callous coat beneath. Mantle free from the back of the neck, with a thick double-edged collar, the outer edge rather reflexed. The front part of the upper surface of the foot near the axis of the shell is depressed into a rather expanded concavity which is lined with an extension of the mantle, having a raised edge near the margin of the concavity. This raised edge is evidently a continuation of the edge of the mantle of the body, sinuated at the columnar and outer upper angle of the mouth of the shell. It is more developed and crumpled up, in the specimens in spirits, on the left side of the concavity; and there is little doubt, in the living state, that this extension of the mantle is expanded out and deposits the polished callous coat of the under surface of the shell and the callosity over the axis; hence the larger size of the left side of the extension.

1. C. Salleana. Spire convex; whorls granulated above.

2. C. eolina. Spire flat; whorls with oblique diverging raised lines.

Lingual membrane of Ceres Salleana broad, elongate, with numerous longitudinal series of teeth. Teeth $00 \cdot 5 \cdot 1 \cdot 5 \cdot 00$ (fig. 100);

Fig. 100.-Teeth of Ceres Salleana.

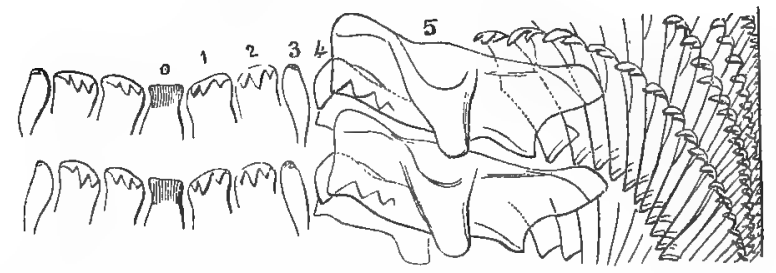

the central tooth oblong, distinct, with a broad simple reflexed tip; the first and second lateral teeth rather broader than the central one, with a three-toothed recurved tip; the third narrow, elongate, with a slightly recurved end; the fourth and fifth much larger, oblong and irregular-shaped; the fourth about half as wide as the fifth, with three or four dentations on the inner side of the upper edge; the 
fifth very large, broad, with a large subcentral reflexed lobe; the lateral teeth are very numerous, subequal, similar, compressed, transparent, with a recurved tip, those of the inner teeth of the series being bifid.

The following Figures were accidentally omitted in their right places.

Fig. 101.-Lingual teeth of Emarginula crassa (p. 163).

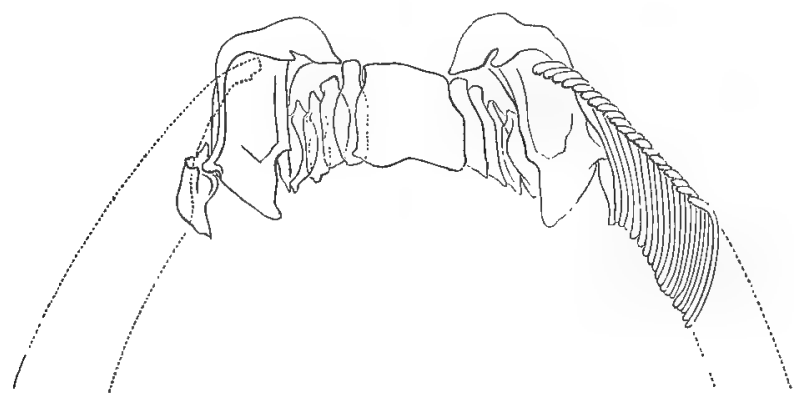

Fig. 102.

Teeth of Tectura testudinalis (p. 169).

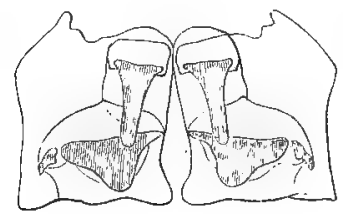

Fig. 103.

Teeth of Lepeta caca* (p. 172).

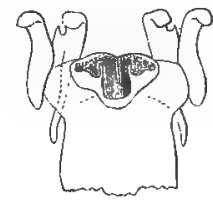

Fig. 104.-Teeth of Patella vulgata (p. 174).

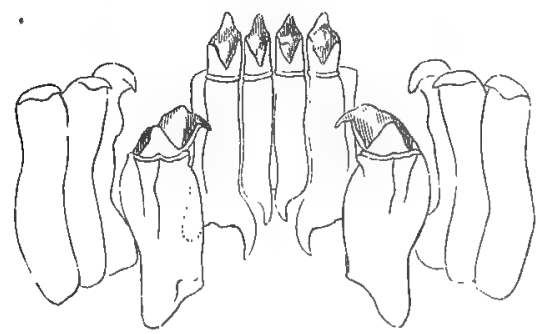

* The figure 92 under this name at p. 172 should be Iothia fulva, and referred to in the description of that genus. 


\section{Subclass II. HETEROBRANCHIATA, Gray.}

Respiratory organs variously formed. Gill exposed, or only slightly covered by a fold of the mantle, or in the form of a lunglike cavity. Hermaphrodite, with reciprocal impregnation (p. 3),

Heterobranchiata, Gray, 1840.

Opisthobranchiata et Pulmonata, M.-Edw. 1846.

\section{Order III. Pleurobranchiata.}

Gill forming a tuft on the side of the back under a fold of the mantle. Shell spiral. Adult and larva shell-bearing; larvæ furnished with deciduous cephalic fins. Animal hermaphrodite, with reciprocal impregnation. Animal and foot elongate, for walking.

A. Organs of generation far apart, united by a groove. Tectibranchia, Rang.

a. The tentacles broad, forming a more or less expanded frontal disk. Bullinina.

"The head-lobe in the Bullide is in fact nothing else than the dorsal and labial tentacles fused into one continuous mass. This Cuvier asserted long ago, and it can very easily be proved on anatomical grounds. The nerves which supply the oral and dorsal tentacles in the Gasteropods go to this lobe, the former to the anterior, the latter to the posterior portion of it (the olfactory nerves to the upper part of it, hence it is the organ of scent)."-Hancock, Ann. \& Mag. Nat. Hist. 1852, 188.

"In Bulla hydatis the olfactory organ is most highly developed, and is perfectly similar in structure to that observed in fishes, and shows the analogy that exists between the dorsal tentacle of Doris and the olfactory organs of this higher type of form. It is composed of a central stem, bearing numerous considerably elevated lateral laminæ. Mr. W. Clark, who described it (Ann. \& Mag. Nat. Hist. 1850 , vi. 100), erroneously considers these "leaflets" salivary glands." --Hancock, Ann. \& Mag. Nat. Hist. 1852, 190.

\section{\$ Teeth in two or four longitudinal series.}

\section{Fam. I. PHILINIDE.}

Teeth in two (or rarely four) longitudinal series, large, hooked, sometimes with a series of smaller similar teeth on the outer side. Head-disk sqüare, broad.

$$
\text { * Shell none. }
$$

\section{1. ? GASTEROPTERON.}

Head-disk triangular ; eyes sessile, subcentral ; body ovate, shell- 
less ; gill exposed; foot oblong; transverse, very large, sides foldec on the back. Teeth ——? Shell none.

"Mouth a linear longitudinal slit; genital pore in front and ven" behind; the gill composed of many plumules, partly covered by $\varepsilon$ fold of the mantle."-Philippi, Moll. Sicil. 97.

1. G. Meckelii, t. $60^{*}$. f. 8 ; t. 131.f. 1. (Clio amata), t. 132. f. 1-10

\section{Posterobranchat.}

Head-disk short, truncated behind. Eyes none. Body and mantle oblong, shell-less, convex, with a triangular bifid posterior process. Foot very broad, oblong, rounded. Teeth —? Shell none.

1. P. maculata, t. 168. f. 2.

The animal requires re-examination. M. d'Orbigny ealls what I have here considered the head-disk and the body, the front and hinder portion of the foot, which, he says, unlike any other mollusk, is divided transversely in half into two very distinct portions. If the above theory is correct, the foot is spotted, and the upper part of the body is one-coloured; but the foot of sereral Aplysia is spotted and variegated.

Messrs. Adams have referred this genus to the Bullida, but they have taken the front part of the mantle (of $\mathbf{M}$. d'Orbigny) for a cephalic disk, though $\mathbf{M}$. d'Orbigny particularly described the mantle as being continuous, and have made their figure to agree with this theory, representing it as divided into two distinct portions (see Gen. Moll. t. 58. f. 5).

\section{** Shell distinct, covered. Gill on right side.}

\section{Doridium.}

Head-disk ovate, truncate behind. Eyes none? Body depressed, truncated behind. Mantle large, oblong, shorter than the expanded foot. Shell covered, thin, flat, triangular,

1. D. marmoratum, t.131.f. 2,3. Eidothea marmorata, Risso (Eur. Mérid.t. 1. f. 17).

2. D. Meckelii, t. 132. f. 1, $1 a$.

\section{Philine.}

Head-disk trapeziform, elongate. Eyes none. Mantle moderate, bluntly notched behind. Foot broad; side lobes large and fleshy, reflexed, edging the head and front of the mantle. Shell concealed, thin, fragile, ovate, convolute; spire small; aperture very large, open.

1. P. aperta, t. 60 . f. 5, t. $60^{*}$.f. 2 , t. 132.f. 6 , t. 175. f. 6 ; Forbes $\&$ Hanley, B.M. t. V.V. f. 1 .

2. P. —, n. s., t. 175. f. 5. Borneo.

3. P. - n. s., t. 132. f. 4. West Indies. 
4. P. granulosa, t. $60 *$. f. 4 .

5. P. Catena, Forbes \& Hanley, B.M. t. V.V. f. 4.

6. P. punctata, Forbes \& Hanley, B.M. t. V.V. f. 5.

7. P. scabra, Forbes \& Hanley, B.M.

$$
\text { t. V.V.f. } 1 .
$$

The young animal (Philine aperta) is covered with a spiral shell furnished with vibratile swimming veils and an operculum. The eggs are numerous, in a very long spiral series, contained in an ovate hydrophanous gelatinous egg-capsule (fig. 105).-Lovén.

Lingual membrane of Philine aperta very narrow, very thin, transparent. Teeth two on each cross series, close together at the base, elongated, arched, nearly in half a circle, brown, compressed, scimitar-shaped; inner edge very finely denticulated; teeth transparent (fig. 106).

Fig. 106. -Teeth of Philine aperta.
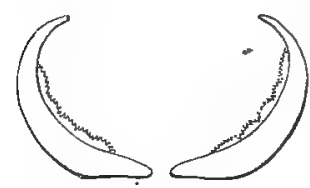

Lateral teeth of Philine scabra two, erect, claw-like, the inmer by far the larger, lobed within, serrulated; outer minute, unarmed (fig. 107).-Lovén.

\section{Hirundella.}

Head-lobe oblong, elongate. Eyes none. Mantle oblong, narrow, produced into two elongated tails behind. Foot large, dilated on the sides, reflexed, and embracing the head and mantle. Shell concealed, flat, thin, scarcely involute.

1. H. hirundinaria, t. 60 . f. 1 .

\section{*** Shell distinct, exposed.}

\section{Cryptophthalmus.}

Head small, narrowed behind. Eyes under the free edge of the disk. Mantle covering the base of the shell. Foot large, elongate ; sides reflexed, subcylindrical, covering the mantle, and with a posterior branchial aperture. Teeth — ? Shell partly exposed, horny, fragile, scarcely involute.

1. C. smaragdina, t. 60. f. 3, 4, 5, 6. Var. Rüppell, t. $60^{*}$. f. 9 .

This may be allied to Bulla. 


\section{Xanthonella.}

Head disk small, broad in front, narrow, bifid behind. Eyes sessile, in middle of disk. Mantle covering the edge of the shell. Foot elongate, oblong; sides reflexed, rounded, enclosing the body, leaving a posterior branchial opening. Shell partly exposed, thin, horny, scarcely involute, without any spire.

l. X. lutea, t. 59. f. 8.

\section{Glauconilla.}

Head disk moderate, acute in front, truncate behind. Eyes in middle of disk. Mantle enclosed. Foot oblong, broad; sides bent up, enclosing part of the shell. Teeth ——? Shell exposed, oval, depressed, thick, green; apex with the rudimentary spine forming a cup-like disk behind.

l. G. viridis, t. 59. f. 5

2. G. glauca, t. 59 , f. 3 .

3. G. Adamsii, t. 178. f. 1 .

\section{Scaphander.}

Head disk large, elongate, subquadrate. Eyes none. Mantle enclosed. Foot short, rather broad, with narrow reflexed sides. Teeth in two lơngitudinal series. Shell exterual, ovate, convolute, striated; spire small, concealed; aperture large, narrow behind.

1. S. lignarius. Bulla 1., t. $60^{*}$. f. 5 ; Forbes \&. Hanley, B.M. t. V.V. f. 5 .

2. ? S. - ? t. 132 . f. 3.

Lateral tooth of Scaphander lignarius single, claw-like, crenulated on the posterior margin before the tip; on the outside winged with a crest on the basal part (fig. 108).-Loven.

Fig. 108.-Teeth of Scaphander lignarius.

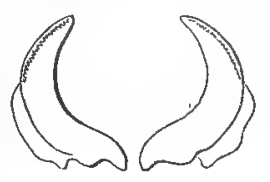

\section{§ Teeth in three longitudinal series (fig. 109).}

\section{Fam. II. AMPHISPHYRAD压.}

Teeth in three longitudinal series, forming straight cross series; the central tooth broad, square; the lateral curved, bent down.

\section{Amphisphyra.}

Animal enclosed in the shell, thick, broad. Head broad, short, transverse. Tentacles short, conical, far apart, lateral. Eyes minute, immersed, remote, posterior. Lips tumid, forming an inflated vertical mouth, impressed in front. Foot shorter than the shell, subquadrate, dilated in front, truncate, divided into two lobes by a medial slit behind; edge of mantle thickened. Shell bubble-like, 
thin, ovate ; apex truncate; spire depressed, with a prominent mammillary first whorl.

I. A. pellucida.

2. A. globosa.

3. A. hyalina, Forbes \& Hanley, B.M. t. Q.Q. f. 2. Teeth, t. 22. f. 2 C. Adams, Gen. Moll. t. 56. f. 8.

Central tooth of Amphisphyra globosa broad, subrectangular; cutting edge transverse, serrulated; lateral tooth one, clawlike, slender, expanded at the base, winged on the outside (fig. 102).-Loven.

Fig. 109.-Teeth of Amphisphyra globosa.

As in Kissoella the eyes are placed far back, so as to be only seen through the transparent shell.

\section{$\$ \S \S$ Teeth in thirteen longitudinal series, in straight cross lines} (fig. 110).

\section{Fam. III. BULLINAD E.}

Teeth : central distinct, lateral $6 \cdot 6$; inner ones large, with a strong hooked point; outer ones uniform, small. Head disk broad, entire or nicked behind. Foot short. Shell exposed.

\section{Bullina.}

Animal short, broad. Head depressed, subquadrate, truncated in front. Tentacles broad, flattened, free, recumbent, transverse. Eyes under their base. Foot very short, ovate, quadrate. Mantle edge thickened, closing the hinder part of the aperture. Teeth $4 \cdot 1 \cdot 1 \cdot 1 \cdot 4$; central broad, pectinate; inner lateral large, curved; rest small. "Prehensile collar distinct," Alder. Shell cylindrical or fusiform. Columella callous or plaited.

* Frontal disk elongate, truncated behind. Cyclina.

1. B. cylindracea, Forbes \& Hanley, B.M. t. V.V. f. 3 ; Adams, Gen. Moll. t. 56. f. 6.

2. B. ? , t. 178 . f. 4 .

\section{** Frontal disk short, deeply notched behind. Tornatina.}

3. B. truncata, Forbes \& Harley, B.M. t. V.V. f. 4 ; Adams, Gen. Moll. t. 56. f. 9 .

Central tooth of Bullina alba small, Fig. 110.-Teeth of Bullina alla. compressed, erect, above wider; cutting: edge slightly produced, serrulated; lateral teeth 6 , first very large, base on both sides produced, with a sharp

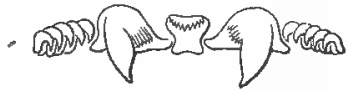
strong point deflected and toothed on the inside, the other teeth minute, bent and claw-like (fig. 110).-Lovén. 
§\$§ Teeth in very numerous close longitudinal series, forming oblique cross series (fig. 111).

\section{Fam. IV. BULLIDA.}

Teeth : central one, distinct; lateral numerous, uniform, in an augular series. Tentacular frontal disk expanded, nicked behind. Shell distinct, exposed.

* Manitle with a long process emitted through a slit in the suture. of the shell. Head dish narrow. Eyes none. Spire convex.

\section{Akrra.}

Head disk elongate, narrow, simple. Eyes none. Mantle enclosed, fringed on the edge. Foot very large ; sides dilated, rounded, folded back in repose. Shell subcylindrical, convolute, thin, elastic ; spire short; suture channeled, notched on the edge.

1. A. bullata, t. $60 *$. f. 6,7 . Forbes $\&$ Hanley, B.M.t.V.V. f. 6. 2. A. ? ? n. s., t. 178, f. 2. Borneo.

Central tooth of Akera bullata minute, erect, base wider, produced on each side; head swollen, impressed above, cutting edge deflected, one-pointed, on each side crested and toothed; lateral teeth about twenty-one, with a long hook, the middle ones longest, the first

Fig. 111.-Teeth of Akera bullata.

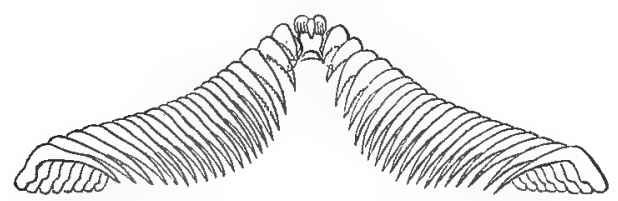

shortly winged on the inside, serrulated, the following gradually more and more slender (fig. 111).-Lovén.

\section{** Mantle simple behind. Head disk broad. Eyes distinct.} Spire of shell minute, sunk; suture simple.

\section{Bulla.}

Head disk broad, sometimes nicked and expanded behind. Eyes subcentral. Mantle enclosed, with a thick posterior lobe. Foot oblong, short; front part of sides bent up. Shell ovate, solid, coloured, involute; spire very small, sunk or hidden.

1. B. Cranchii, Forbes \& Hanley, B.M. t. V.V. f. 2.

2. B. ampulla, t. 178 . f. 3 .

3. B. ovoidea, t. 59 . f. 4.

4. B. glauca, t. $59 . \mathrm{f}, 3$.

5. B. striata, t. 60 . f. 2 , t. 175 . f. 4 . 
6. B. Columni, t. 59. f. 1 .

7. B. Hydatiuella, t. $60^{*}$. f. 3 .

\section{Haminea.}

Head disk large, elongate, naked behind. Eyes subcentral. Mantle edge reflexed on shell behind. Foot elongate; sides expanded, reflexed on shell. Shell ovate, thin, horny, striated; spire very small, sunken.

1. H. hydatis?, t. 60 . f. 1, -2 , t. $60^{*}$, f. 2 .

2. H. ?, t. 132 . f. 4 .

3. H.? ? ? t. 178 . f. 5 .

4. H. hydatis, Forbes \& Hanley, B.M. t. Q.Q. f. 3.

Teeth of Haminea hydatis in very numerous longitudinal series, of uniform similar conical acute glassy teeth in close angular cross series.

"The branchial plume of Bulla hydatis is a single, regular, crescentshaped plume of 18 or 20 short, coarse strands, having the artery in the centre, lying in a crypt transversely between the vulva and the anus, floating free, except where under the mantle it is fixed to its roof and to the back of the animal. The heart is at the base of the branchiæ."-Clark, Moll. p. 280.

\section{Fam. V. AMPLUSTRID $Æ$.}

Teeth : central none; lateral numerous, uniform. Frontal disk produced into ear-like tentacular lobes. Front of aperture of shell more or less channeled. Operculum none.

\section{Amplustrum.}

Shell ovate, imperforated, solid, smooth; spire distinct, conical, blunt; aperture oblong; with a broad canal in front.

1. A. aplustre, t. 59. f. 2 , t. 175. f. 1 .

\section{Bullinula.}

Shell ovate, solid, perforated, transversely grooved and dotted; spire conical, blunt; aperture linear, ovate, broadly channeled in front.

1. B. undata, t. 59. f. 6 .

2. B. ? , t. ] 32 . f. 5 .

\section{Hydatina.}

Shell involute, ovate, thin ; axis perforated ; spire flattened ; aperture entire in front.

1. H. Physis, t. 59. f. 7, t. 175. f. 2, 3, t. 262 . f. 1 . 
Central tooth of Hydatina Physis wanting; lateral teeth about thirteen, somewhat equal, thick, hooked, reduced in front and at the base; marginal teeth $4 \cdot 5$, unequal (fig. 112).-Lovén.

Fig. 112.-Teeth of Hydatina Physis.

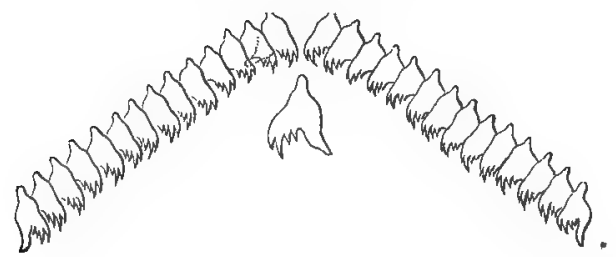

The genus Atlas, Lesueur, has been referred to this family. It is said to be the larva of Siphunculus. See J. Müller, Entwick. der Echinod. 36, and Busch, in Arch. Naturg. 1854, 333.

b. Tentacles slit externally, ear-like, separate. Head produced. Teeth in very numerous longitudinal series, forming angular cross lines, all similar (p.191).

$\dagger$ Shell internal or none (p. 201).

Fam. VI. APLYSIAD正.

Shell internal, rudimentary; nucleus globular, spiral. Teeth in many longitudinal series; central 1, distinct ; lateral nụmerous, similar. Tentacula separate, ear-like.

* Sides of foot dilated, covering the back, not expanded for swimming. Shell hard, calcareous, covered by the mantle.

\section{Dolabelita.}

Animal elongate, obliquely truncated behind; sides of foot inflexed. Shell calcareous, triangular, convex; 'apex callous. Periostraca hard.

+ Body warty. Shell broad.

1. D. callosa, t. 137. f. 2. D. Rumphii, t. 134. f. 1, t. 135.

2. D. — ? t. 133.

3. D. —?, n. s., t. 207. f. 2. Ceylon.

†† Body smooth. Shell broad.

4. D. ecaudata, t. 136. f. 2.

5. D. Tongensis (Aplysia de Tonga), t. 137. f. 1.

㠹 Body and shell elongate.

6. D. temnida, t. 136. f. 1, t. 270 . f. 1 . 


\section{Dolabrifera.}

Body tapering behind. Shell calcareous, trapeziform; apex produced.

1. D. Dolabrifera, t. 149. f. 1 .

2. D. ascifera, t. 149. f. 3 .

3. D. Oahouensis, t. 220 . f. 5 .

** Sides of foot dilated, free for swimming. Shell subcartilaginous, covered by the mantle.

\section{Aplysia.}

Body elongate, conical behind. Shell subcartilaginous, ovate; apex acute.

1. A. depilans, t. 138.f. 1, t. 142.f. 1, 2, jun.? Esmia Grifrithsiæ, t. 268. f. 13. Young from eggs, t. 154. f. 1 .

2. A. virescens, t. 61 . f. 3 .

3. A. punctata, t. 139 . f. 1, t. 140. f. 1, t. 146. f. 2 , t. 177. f. 5 .

4. A. Lepus, t. 146. f. 3 .

5. A. marginata, t. 146. f. 1 .

6. A. ocellata, t. 148 .

7. A. rosea, t. 138. f. 2.

8. A. Lessonii, t. 139. f. 2 .

9, A. Brasiliana, t. 140. f. '2.

10. A. Keraudrenii, t. 141 , f. 2 .

11. A. fusca, t. 141. f. 1.

12. A. maculata, t. $142 *$. f. 1 .

13. A. hybrida, Forbes \& Hanley, B. M. t. F.F. f. I.

14. A. fasciata, t. $142 *$. f. 3 .

15. A. Inca, t. $61^{*}$. f. 2 , t. 144. f. 1 .

16. A. dactylomela, t. 144. f. 2.

17. A. protea, t. 144. f. 1 .

18. A. Camelus, t. 145. f. 1.

19. A. alba, t. 145. f. 2.

20. A. Sicula, t. 147. f. 3.

21. A. nigra, t. 147. f. 1.

22. A. Sorex, t. 149. f. 8.

23. A. Ferussacii, t. 149. f. 7 .

24. A. longicornis, t. I49. f. 4 .

25. A. marmorata, t. 149 . f. 6 .

26. A. lurida, t. $61^{*}$. f. 1 .

27. A. Rangiana, t. $61 *$ f. 3.

28. A. Julienna, t. 61..f. 1 .

29. A. Tigrinella. A. Tigrina, t. $61 *$ *. f. 4.

30. A. petalifera, t. 149. f. 5 .

31. A. linguifera, t. 149. f.' 2 .

32. A. Argus, t. 143. f. 2 , t. 270 . f. $3,4$.

33. A. Brugnatelli, t. $142^{*}$. f. 4 .

34. A. Webbii, t. $142^{*}$. f. 2 .

35. A. depressa, t. 147. f. 4. 
36. A. Dumortieri, t. 147. f. 3 .

37. A. limacina, t. 151. f. 2.

38. A. Rissoana. Dolabella Lepus, Risso, l'Europ. Merid. t. .f. . 39. A. Neapolitana, t. 3. f. 2.

Lingual membrane of Aplysia depilans broad, short, brown. Teeth brown, many on each diverging cross series; central tooth

Fig. 113.-Teeth of Aplysia punctata.

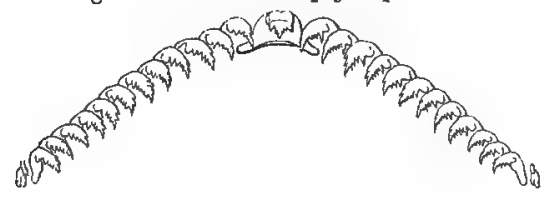

distinct and truncated, triangular, dilated beneath, with an arched front edge ; apex truncated, reflexed ; reflexed part subcordate, dark, with three large toothlets in front; lateral teeth $12 \cdot 12$, in an oblique line, rather elongate, oblique, with the tip recurved, with three rounded lobes on its lower edge; the crown of the anterior teeth worn, so as to leave the reflexed and lobed part.

Central tooth of Aplysia punctata with the base on each side expanded; apex recurved, with one sharp point lobed on both sides; lateral teeth about thirteen, minute, claw-like, denticulated, lobed and toothed at the bend; outer ones misshapen (fig. 113).-Lovén.

\section{*** Sides not dilated. Foot narrow. Shell none.}

\section{Notarchus.}

Animal ovate; hinder tentacles simple. Foot linear, narrow. Shell none.

1. N. Cuvieri, t. 53. f. 3, t. 152. f. 3 , t. 153 . f. 1,3 .

2. N. gelatinosus, t. 61. f. 2 , t. 153. f. 2 .

3. N. punctatus, t. 153. f. 5 .

4. N. ocellatus, t. 152 . f. 2 .

5. ? N. (Bursiris) griseus, t. 198. f. 8.

\section{Bursatelila.}

Animal globular, bearded; hinder tentacles branched. Shell none.

1. B. Leachii, t. 150, t. 153. f. 4 .

2. B. laciniatus, t. 152 . f. 1 .

3. R Pleii, t. 151.f. 1 .

\section{Aclesia.}

Animal elongate, tapered behind, bearded. Tentacles linear, papillary. Lips elongate, dilated on the sides.

1. A. longicauda, t. 151. f. 4 .

2. A. undata, t 152 . f. 5 . 
3. A. citrina, t. i5l. f. 6 .

4. A. viridis, t. 151 . f. 7.

5. A. rufa, t. 61 . f. 5 .

6. A. striata, t. 61.f. 3 .

7. A. cirrigera, t. $6 \mathrm{l}$. f. 1 .

8. A. ocellata, t. 179 . f. 2 .

9. A. Fuclorus, t. 179. f. I.

†† Shell external (p. 198).

Fam. VII. LOPHOCERCID A.

Body elongate. Head produced. Tentacula two, ear-like. Eyes ? Gill regular, pectinate. Male organ on right side of nape, near tentacle; female —? Mantle enclosed. Tail conical. Shell exterior, convolute. Teeth in numerous longitudinal series; central 1 , distinct; lateral numerous, similar, in an angular cross series.

\section{LOPHOCERCUS.}

Shell convolute; spire rudimentary, subcentral.

1. L. Sieboldii, t. 176. f. 3 ; Souleyet, Journ. de Conch. 1850, 225. t. 10. f. $1,2,3,15,17$.

The tongue is exactly like that of Acteon in form and structure. —Souleyet, Journ. de Conch. 1850, 228. t. 10. f. 9. Gill pectinate, on left side of the mantle lobes.

Mantle of Lophocercus enclosed. Foot elongate, produced and attenuated behind; the sides of the front expanded, bent up, and covering the sides of the shell. Eyes sessile, behind the base of the tentacles. The aperture of the male organs at the hinder part of the base of the right tentacles; of the female on the edge of the branchial cavity (united by a groove?). Gill a transverse series of simple isolated leaves, attached to the upper inner surface of the respiratory cavity.

\section{LOBIGER.}

Shell spiral, ovate; spire small, apical.

1. L. Philippi, t. 176. f. 1 ; Souleyet, Journ, de Conch. 1850, 223. t. 10 . f. 14,18 .

B. Organs of generation close together in one tubercle (p. I91).

$\S$ Teeth in numerous longitudinal series, uniform (p. 204).

Fam. VIII. PLEUROBRANCHID $A$.

Animal rounded, convex. Head not produced, hidden under the edge of the mantle. Tentacles two, close, slit on the outer side; frontal veil more or less produced between the base of the tentacles 
and the mouth. Proboscis retractile. Foot large, expanded. Shell enclosed in the mantle, rudimentary or none.

\section{* Mantle distinct. Shell distinct.}

1. Preurobranchus.

Mantle oblong, margining the foot, entire in front; frontal veil moderate, rounded. Shell large, oblong, horny.

\section{+ Shell oblong; horny.}

1. P. Peronii, t. 167. f. 1 (in spirits), 6 (alive), 8.

2. P. plumula, t. 167 . f. 4 ; Forbes \& Hanley, B. M. t. X.X. f. 1 .

3. P. perforatus, t. 171 . f. 4 .

4. P. aurantiacus, t. 167. f. $3,5,9$, t. 174. f. 1 .

5. P. De Haanii, t. 167. f. 2.

6. P. brevifrons, t. 171 . f. 3 .

7. P. —?, t. 169. f. 1 .

8. P. Patagonicus, t. 171 . f. 1.

9. P. cornutus, t. 174. f. 2.

10. P. punctatus, Quoy, Voy. Ast. t. 22. f. $15,19$.

11. P. tuberculatus.

12. P. stellatus.

13. P. ocellatus.

14. P. ? ?, t. 3. f. 2 , t. 166. f. 1, t. 169. f. 5 .

15. P. Blainvillii, t. 172. f. 1 .

16. P. mammillatus, t. 174 . f. 4 ,

\section{†† Shell narrow; shelly?}

17. P. oblongus, t. 170, t. 173. f. 1.

The branchia of Pleurobranchus plumula consists of a gently arcuated stem; having on each side 20 to 25 oblique rami sloping posteriorly, which are finely ciliated, to beat the water to extract the air; the two sets of strands fall together from each side of the stem, forming when expanded an elegant plumose rouleau, tapering gently from its origin to a conical, though obtuse, posterior termination, and for a third of its length floating free.-Clark, Moll. p. 271.

\section{Susania.}

Mantle very large, broadly margining the foot, vesicular, deeply notched in front; frontal veil between the base of the tentacles and mouth, large, oblong. Foot oblong, rather narrow. Shell rery small. Teeth very numerous, in close oblique series; no central tooth.

1. S. testudinaria, Phil. Moll. Sicil. t. 20, 2 l, f, 1.

2. S. Forskalii, t. 169 . f. 4 .

3. S. tuberculata, t. 172. f. 2 .

4. S. reticulata, t. 169. f. 3. Perhaps all one species. 
The lingual membrane of $\boldsymbol{S}$. testudinaria is broad, short, with very numerous close longitudinal series of slender, curved, acute, subulate teeth, placed in close oblique cross rows, without any central series.

\section{Oscanius.}

Mantle expanded, irregular. Foot very large, expanded. Shell thin, membranaceous, silvery.

1. O. membranaceus, t. 103. f. 12 ; Forbes \& Hanley, Brit. Moll. t. X.X. f. 2.

2. O. Lesueurii, t. 166 . f. 2.

3. O. dilatipes, Adams, Gen. Moll. t. 60. f. 5 .

The branchial plume of Oscanius membranaceus is composed of two gently arcuated leaves, tapering from their bases to a pointed extremity; each leaf consists of about twenty-five linear vessels or processes, resembling a twisted cord with a longitudinal depression in its centre, which is the branchial artery, and crossed on each side by transverse lines; these cord-like fillets are closely packed together and taper to their terminations, which float free. The two portions of the plume fold on each other, with fine short cilia on each of the striæ, to beat the water and eliminate air therefrom.Clark, Moll. p. 269.

\section{** Mantle indistinctly edged. Shell none.}

\section{NeDA.}

Mantle small, indistinct. Foot broad, dilated, rounded behind; lateral appendage dilated, cut on the sides, arcuate.

1. N. luniceps, t. 167. f. 2 ; Adams, Gen. Moll.t. 61.f. 1 .

\section{Pleurobranchate.}

Mantle small, indistinct. Foot narrow, oblong; lateral appendages forming a narrow veil. "Eyes small, at the hinder base of the hinder tentacles." - Chiaje.

1. P. Meckeli, t. 168. f. 1, 3, t. 173. f. 2, 3 (from life), t. 220 . f. 3 (young).

2. P. maculata, t. 22. f. 12.

The proboscis in the living animal is always retracted, but when languid, or in spirits, generally exserted, thick and truncated. The lingual membrane broad, dark brown, longitudinally folded, with very numerous, crowded, longitudinal series of elongate, subulate, slightly curved, acute, transparent teeth, in crowded oblique cross series.

Fam. IX. TYLODINADÆ (from p. 63), add-

Shell exterior, thin, with a thick periostraca; apex subcentral; nucleus globular, spiral, sinistral. Misscular sear ring-like, with a 
broad angular sinus on the hinder part of the right side. Mouth like Pleurobranchus. Lingual membrane broad. Teeth in many longitudinal series, forming angular cross lines. Gill pinnate, like Pleurobranchus. The animal and shell evidently intermediate between Pleurobranchide and Umbrellade.

\section{Fam. X. UMBRELLAD E.}

Body suborbicular. Head not produced. Tentacles two, slit on the outer side. Mouth sunk in the groove, with a retractile proboscis. Teeth in numerous longitudinal series, similar. The foot large, thick, including the viscera, deeply notched in front. Mantle enclosed. Shell external, conical, calcareous. Muscular scar ringlike, submarginal.

\section{UMBRELLA.}

1. U. umbellata, t. 163 . f. $1,2,4$, t. 165 .

2. U. Mediterranea, t. 163. f. 3, t. 164 .

Lingual membrane of Umbrella Mediterranea broad, longitudinally plaited. Teeth in numerous oblique cross lines, each containing very many small, closely pressed, compressed, sharp-edged, transparent teeth.

Foot of Umbrella Mediterranea very large, thick, including the viscera, flat.beneath, scarcely elevated above, deeply notched in front, and externally covered with large, irregular, rounded tubercles. The mantle small, enclosed under the shell, finely toothed on the edge. Gill on the right side, continued behind nearly to the left side, formed of many compressed, elongate, pinnatifid leaves connected at the base. Vent prominent, behind the end of the gill. Tentacles two, placed above the fissure of the foot, contractile, oblong, linear, longitudinally slit externally. Eyes small, on the inner side of their base. The orifices of generation in the anterior fissure, below the tentacles, surrounded with some lips; and, below the opening of the mouth, furnished with many lips, the outer of which is called, by Blainville and Della Chiaje, the "buccal tentacles." - Philippi, Moll. Sicil. t. 7. f. $11,11 a$.

De Blainville erroneously describes the organs of two sexes in the same individual, the oviduct in the front part of the right side, with a short groove to the root of the male organ, which is at the base of the hinder right tentacle.

\$ Teeth in three (or seven?) longitudinal series. Body elongate, covered with a mantle. Tentacles none? (p. 201).

Fam. XI. RUNCINAD旡.

Body elongate, lanceolate. Mantle distinct. Gizzard testaceous. 
Tentacles none? Eyes lateral. Teeth in three longitudinal series; central broad, dentate; lateral conical, versatile? Vent centrally posterior, beneath the edge of the mantle, and accompanied by a few slightly pinnate branchiæ. Generative organs on right side. "External appearance of Pelta."-Quatrefages.

\section{Runcina.}

Body elongate, smooth, depressed. Mantle oblong, rounded, covering the head in front, as broad as, and parallel with, the foot on the sides, rather shorter than the foot, and slightly produced and recurved behind. Gill formed of three small plumes, placed under the hinder part of the cloak a little to the right of a central tubular anus. Mouth beneath the mantle, linear, T-shaped, covered with spines. Eyes two, on the sides of the front of the mantle. Organs of generation on the right side. Tongue strap-shaped. "Gizzard a little behind the tongue, consisting of four portions, each bearing six denticulated teeth."-Alder, t. 4.f. 6. Foot elongate, truncated, rounded on the sides in front, rather produced, and tapering behind.

1. R. Hancocki, Forbes \& Hanley, B.M. t. C.C.C. f. 2. Limapontia, Ann. \& Mag. Nat. Hist. xviii. 289. t. 4.

Lingual membrane of Runcina Hancocki white, broad. Teeth $1 \cdot 1 \cdot 1$ ?, transparent; central broad, trausverse; apex recurved, with a broad, three-toothed denticle on each side the middle line; lateral conical, broad at the base, acute, and curved at the tip; prehensile collar large, rugese, with roundishtipped tubercles (fig. 114).

Mantle of Runcina Hancocki separated

Fig. 114.--Teeth of Runcina Hancocki.

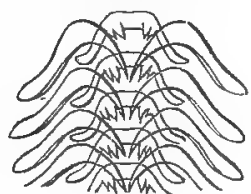

from the foot by a very distinct groove, truncated in front, raised on each side of the front, and paler edgéd; hinder end rounded, pale at the tip. Gills laminar; leaves rounded, subimbricate, on the right side of the hinder part of the mantle-groove. Foot pale, distinct, simple-edged, pale beneath. On bleached Laurentiæ in shallow water, Weymouth.

Mantle rather coriaceous, the front portion containing the eyes, and separated from the hinder portion of the mantle by a paler band, regarded as the frontal disk of the Bullida?

\section{Order IV. Gy m о BRANCHI A}

Gill exposed or contractile into cavities on the surface of the mantle. Adult animal without any shell. Larva shell-bearing, furnished with deciduous cephalic fins. Animal hermaphrodite, with reciprocal impregnation. 


\section{Synopsis of Suborders.}

I. Pygobranchia. Gills on the middle of the hinder part of the back, surrounding the vent, plurnose or branched. Skin spiculose.

II. Inferobranchia. Gills on the under side of the expanded mantle, lamellar.

III. Polybranchia. Gills on the upper surface of the mantle, lamellar or plumose.

IV. Cerabranchia. Gills on the upper surface of the mantle, fusiform, papillary, simple or branched.

V. Pracobranchia. Gills on the upper surface of the mantle, lamellar or venose, spread over the surface.

VI. Percibranchia. Gills none distinct, the function being performed by the skin.

\section{Suborder I. Pygobranchia.}

Gills on the middle of the hinder part of the back, surrounding the vent, plumose or branched. Skin spiculose.

The skin of the Doride is tough and coriaceous, and is of a spongy or cellular structure within the mantle in all the British species examined, stiffened with numerous imbedded spicula having a more or less symmetrical arrangement. Spicula are also observed on the foot, on the tentacles, and on the root of the branchial plumes. The under surface of the foot, the upper surface of the cloak, the branchial plumes, and the dorsal tentacles, are covered with vibratile cilia.-Hancock \& Embleton, Phil. Trans. 1852, 243.

Professor Ehrenberg observes, "In tota Doridinorum familia maxillæ desunt; in hac forma palatum denticulorum densa fascia fusca armatum est, denticuli vero non seriatim dispositi sunt."-Symb. Phys. Moll. i.

A. Body convex. Mantle large, margining the foot, without marginal appendages. Dorsal tentacles two, retractile into cavities. Oral tentacles two, or wanting (p. 211).

a. Lingual membrane narrow. Teeth in two principal longitudinal series, and sometimes two smaller series (p. 208).

Fam. I. ONCHIDORIDA.

Body convex. Mantle large, margining the foot. Dorsal tentacles laminated. Head veiled. Branchiæ non-retractile. Lingual membrane narrow, with two longitudinal rows of teeth, and sometimes one or two lateral rows of smaller teeth on each side. 


\section{ONCHIDORIS.}

Body depressed. Mantle large, strengthened with spicula. Dorsal tentacles laminated. Head veiled, distinct. Oral tentacles none. Gills simply pinnate, set in an open circle, non-retractile. Lingual membrane narrow, with two rows of large, and two of small rudimentary ones.

1. O. Leachii, t. 67. f. 9,15, t. 214. f. 1, t. 268. f. 7.

2. O. muricata, t. 67 . f. 5 .

3. O. diaphana, t. 217. f. I.

4. O. pusilla, t. 217 . f. 2.

5. O. sanguinea, t. 223. f. 5 .

6. O. ? ?. t. 233. f. 4 .

7. O. sparsa, t. $271 . f$.

In Onchidoris Leachii the cloak is armed with moderate-sized spicula. The spawn is cup-shaped, of few coils. 'The tongue with two large spines and two or more rudimentary ones; usually a simple central plate.-Alder.

O. depressa has a very flat body, with large spicula symmetrically arranged. Spawn in many narrow coils. Tongue with two large broad spines and two rudimentary ones; no central plate.-Alder.

\section{Acanthodoris.}

Body convex. Mantle with soft conical tubercles. Dorsal tentacles larninated, retractile within marginated cavities; oral tentacles leaf-shaped, united into a veil. Gills united at the base, nonretractile. Tongue narrow, with two large denticulated spines and six or eight rudimentary ones; no central plate; a spinose buccal collar, with rudimentary under-jaw.-Alder.

1. A. pilosa, t.67.f.6,10. Doris sublæevis, t.231.f.9. D. Flemingii, t. $67 . \mathrm{f} .11$.

2. A. lævis, t. 69. f. 6, t. 2]4. f. 6 .

Branchial plumes of Acanthodoris pilosa with a double row on each plume stem of irregularly globular hollow bodies, with elastic walls separating the inner and outer channels of the stem from each other, forming a white star-like centre to the gills. Found from coralline zone to half-way between low- and high-water mark.-Hancock \& Emb. Phil. Trans. 1852.

\section{ViliLiersia.}

"Mantle with a continuous calcareous shield, pierced with holes for the tentacula, gills and vent." - D'Orb. Teeth - ?

1. V. scutigera, t. 213. f. 1. 
b. Lingual membrane broad. Teeth in many longitudinal series (p. 206).

Fam. II. DORIDIDÆ.

Teeth in many longitudinal series, in each cross series nearly similar; the inner often smaller. Body convex. Mantle large, convex, covering the head and margining the foot, without any marginal appendages. Dorsal tentacles two, retractile within cavities; oral tentacles two, various or wanting.

Lingual membrane broad, flat or channeled, received within the throat; central series often toothless; lateral series of teeth sometimes very numerous.

"We are inclined to think these denticles are siliceous in composition, as they resist the action of the stronger mineral acids, as do those of Eolis, which, although they possess the same hardness, transparency and polish; are in some measure affected by hydrofluoric acid."-Hancock \& Embleton, Phil. Trans. 1852, 211.

* Gills retractile into a common cavity. Tentacula dorsal, distinet.

\section{Glossodoris.}

Mantle largely tubercular. Dorsal tentacles conical, laminated, partially retractile, and protected by leaf-like appendages ; oral tentacles linear or tubercular. Gills linear, simply pinnate. Lingual spines simple, uniform; no central spine.

1. G. verrucosa, t. 65 . f. 1 , 't. 236 . f. 1 .

2. G. Bertholeti, t. 218. f. 1.

3. G. D'Orbignii, t. 216 . f. 2

\section{Chromodoris.}

Body subquadrangular. Mantle narrow, exposing the foot, smooth. Dorsal tentacles laminated, retractile within plain or marginated. cavities; oral tentacles conical or tubercular. Gills linear, simply pinnate, retractile? Tongue - ?

1. C. magnifica, t, 64. f. 2, t. 67. f. 17 .

\section{ACTINODORIS.}

Mantle large, flat, tubercular. Gills strap-shaped, cut or forked at the tip, retractile into a common carity. Teeth - ?

1. A. flammulata, t. 234. f. 2.

2. A. scabra, t. 66 . f. 1 .

3. A. cruenta, t. 66 . f. 3,4 .

4. A. maculosa, t. 66 . f. 5 .

5. A. fumosa, t. 216 . f. $1=$ Doris Incii, t. 226 . f. 1.

6. A. sordida, t. 213 . f. 3.

7. A: punctata, t. 64 . f. 5 .

8. A. Mauritiana, t. 234 . f. 1 . 
9. A. Krusensternii, t. 230 . f. 5 .

10. A. Tilesii, t. 230 . f. 4.

11. A. tuberculosa, t. 65 . f. 4.

\section{Asteronotus.}

Mantle very large, flat, coriaceous. Dorsal tentacula laminated; conical; oral tentacula leaf-shaped. Gills each with several pinnate rays branching from a footstalk. Lingual spines _- ?

1. A. cruenta. Doris c., t. 226. f. 2. Torres Straits.

\section{Actinocyclus.}

Mantle large, flat. Tentacles two only, laminate. Gills in front of the vent, not surrounding it. Lingual spines - ?

1. A. velutinus, Ehrenb.

\section{Atagema.}

Mantle large, keeled on the back. Dorsal tentacles laminated, truncated. Gills very small, at the end of a dorsal sac. Teeth _-? Lingual spines —?

1. A. carinata, t. 64. f. 11 .

\section{Dendrodoris.}

Mantle more or less tubercular. Gills large, 4- or 5-lobed; lobes doubly pinnate; vent rather behind the gills.

1. D. tuberculata, t. 68. f. 1, 8, t. 229. f. 6, t. 231. f. 11, t. 233 . f. 1 .

2. D. limbata, t. 67 . f. 13 , t. 68 . f. 3, t. 236 . f. 4,6 .

3. D. setigera, t. 229. f. 5 .

4. D. glandifera, t. 229 . f. 8, t. 236 . f. 5 .

\section{Doris.}

Mantle convex, tubercular. Gills arborescent, retractile; vent in centre of gills.

1. D. Argo, t. 64 . f. 12 , t. 65 . f. 2 , t. 229 . f. 7 , t. 233 . f. 3.

2. D. Johnstonii, t. 67 . f. 4 , t. 215 . f. 1 .

3. D. obvelata, t. 67 . f. 7 , t. 225 . f. 1 .

4. D. flammea, t. 215 . f. 3 .

5. D. planata, t. 225 . f. 2.

6. D. testudinaria, t. 23 . f. 2 , t. 68 . f. 2 .

7. D. Semele, t. 69 . f. 8.

8. D. punctata, t. 67 . f. 7 .

9. D. aurea, t. 230 . $f$.

10. D. violacea, t. 224 . f. 1.

11. D. venosa, t. 64 . f. 8.

12. D. impudica, t. 64 . f. 13.

13. D. limacina, t. 64. f. 6 . Gill on middle of back. 
14. D. tomentosa, t. 231 . f. 8.

15. D. coccinea, t. 271 . f. 1 ; Forbes \& Hanley, B.M. t. V.V. f. 2.

16. D. nigricans, t. 229 . f. 1 .

17. D. - ?, t. 230 . f. 1 .

18. D. albolimbata, t. 213 . f. 2 .

19. D. tenera, t. 214. f. 5 .

20. D. luteo-rosea, t. 229 . f. 4.

21. D. punctata, t. 218. f. 2 .

22. D. —?, t. 233 . f. 1 .

23. D. candida, t. 269. f. 4. Gill on middle of back.

Central tooth of Doris obvelata minute, erect, base expanded, apex rounded, cutting edge bent down, crested and denticulated; lateral teeth on both sides about 20 , each of them a bent hook serrulated on the lower margin, scape shorter; teeth in the middle of the series the largest (fig. 115).

Fig. 115.-Teeth of Doris obvelata.

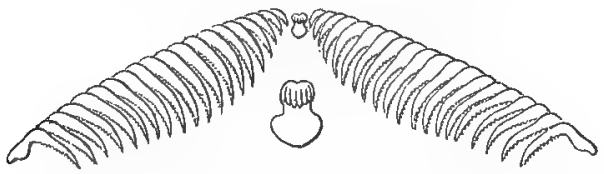

"The dorsal tentacles of $D$. tuberculata conical ; oral tentacles tubercular; cloak with hard spiculose tubercles. Lingual spines simple, uniform; no central spine."-_Lovén.

"The dorsal tentacles of $D$. Zetlandica conical; oral tentacles tubercular; cloak with soft tubercles. Lingual spines long, linear, obtuse, denticulated; no central spine.

" In D. Johnstonii the dorsal tentacles clavate; oral tentacles linear. Lingual spines of two forms; no central spine.

"The dorsal tentacles of $D$. repanda linear; oral tentacles angular, flattened. Lingual spines denticulated; a small central spine. Mouth with a spinous collar." - Alder.

** Gills set separately round the vent, and each retractile into its proper cavity.

\section{Hexabranchus.}

Mantle very large, flat, waved on the edge. Dorsal tentacles laminated, kneed, retractile within marginated cavities; oral tentacles large, ovate, waved on the edge. Gill tree-like, in a ring. Teeth

1. H. pretextus, t. 237 .

2. H. sanguineus, t. 68 . f. 4 .

3. H. laciniatus, t. 65 . f. 3 , t. 230 . f. 2 .

4. H. marginalis, t. 221 . f. 2 , t. 224 . f. 2 .

5. H. Sandwichensis, t. 235 .

6. H. Adamsii, t. 219 . f. 1. 
10. Heptabranchus.

Gills tree-like, in a broad lunate series. Teeth - ?

1. H. Burnettii, t. 219 . f. 2.

B. Body more or less compressed. Mantle small, sometimes obsolete, often furnished with marginal beards. Tentacles variable. Jaws sometimes distinct (p. 206).

a. Lingual membrane narrow, with four longitudinal series of teeth (pp. $213 \& 214)$.

Fam. III. GONIODORID $\mathrm{A}$.

Body angular, depressed. Mantle small or obsolete, with waved or scalloped edges, spiculose. Dorsal tentacles laminated, non-retractile; oral tentacles flattened. Gills not retractile. Lingual membrane narrow. Tongue with four longitudinal series of spines; no central series; buccal collar spinose.

\section{* Mantle edge simple.}

\section{Goniodoris.}

Body depressed; cloak distinct, with a waved or scalloped edge. Dorsal tentacles laminated; oral tentacles flattened. Lingual membrane narrow, with four series of plates, the two medial each with a large central spine; no central plate; buccal collar spinose.-Alder. Gill lanceolate, pinnate, non-retractile.

1. G. nodosa, t. 69 . f. 10 , t. 227. f. 1 , t. 231 . f. 3,5 , t. 268.f. 9 ; Forbes \&. Hanley, B.M. t. V.V. f. 3.

2. G. margimata, t. 223. f. 3 .

3. G. castanea, t. 220 . f. 2 , t. 222 . f. 1 .

4. G. pulcherrima, t. 232. f. 1 .

5. G. Villefranca, t. 232 . f. 2 .

6. G. elegantula, t. 231. f. 7 .

7. G. purpurea, t. 234 . f. 4 .

8. G. picta, t. 213 . f. 4 , t. 23 L. f. 17.

9. G. cærulea, t. 229 . f. 2 , t. 231 . f. 10 .

10. G. albescens, t. 229 . f. 3.

11. G. marmorata, t. 64. f. 14.

12. G. Webbii, t. 232 . f. 5 .

13. G. impudica, t. 232 . f. 4 .

14. G. tinctorum, t. 69 . f. 5 .

15. G. obsoleta, t. 69 . f. 4 .

16. G. pallida, t. 69 . f. 3 .

17. G. infuscata, t. 69 . f. 2 .

18. G. pulchella, t. 66 . f. 2 .

19. G. atromarginata, t. 64 . f. 4,10 , t. 180 . f.

20. G. lemniscata, t. 223 . f. 6 . 
21. G. reticulata, t. 64 . f. 7 .

22. G. elegans, t. 64 . f. 9.

23. G. lineata, t. 220 . f. 4 .

\section{Brachychlanis.}

Body prismatic. Mantle small, slightly margined. Tentacle in front of mantle. Teeth - ?

1. B. pantherina, Ehrenb.

** Mantle edge bearded.

\section{Idalia.}

Body oblong, convex, smooth. Head much produced in front, plain, thick. Mantle very small and indistinct, margined with a semicircle of beards, largest in front of the tentacles. Tentacles two; dorsal linear, laminated, with a simple appendage in front, but distinct from them. Gills simply pinnate, non-retractile. Lingual membrane narrow, with four series of spines, the two central series larger; no central spine; buccal collar spinose.

1. I. elegans, t. 199 . f. 10.

2. I. cirrigera, t. 231 . f. 1,4 .

3. I. aspera, t. $215 . \mathrm{f}, 2$.

4. I. quadricornis, t. 223 . f. 2.

5. I. dubia, t. 232 . f. 6 .

6. I. Lessonii, t. 204. f. 9 , t. 274 . f. 3 .

7. I. inæqualis, Forbes $\&$ Hanley, B.M. t. V.V. f. 4.

Ceratodoris eolida, t. 67. f. 5, is supposed by Mr. Alder to be a young Idalia.

"The centre of the back of I. elegans with filaments. Lingual spines next the centre falcate, and smooth, or minutely denticulated; extermal spines short ; spinose collar complete.'-Alder.

"The centre of the back of $I$. asper $a$ without filaments. Lingual spines next the centre recurved and strongly denticulated; external spines much hooked; spinose collar incompletely bilobed."-Alder.

Fig. 116.-Teeth of Idalia eirrigera.

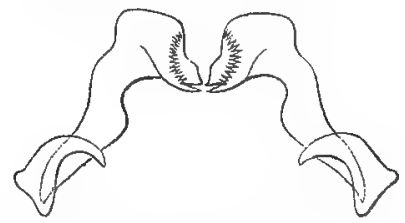

"Central tooth of Idalia cirrigera none; lateral teeth two, first very large, scape produced on both sides, longest on the outside, tip clavate, armed with an incurved sharp point, serrated on the inside (fig. 116)."-Lovén. 


\section{Ancula.}

Head produced at the sides into tentacular processes. Body elongate, slug-like, smooth ; forehead simple, without any veil. Mantle obsolete, forming a semicircular ridge of simple or clavate beards, surrounding the plumose non-retractile gills, round the vent. Tentacles two, clavate, laminated, with filiform non-retractile styliform appendages on the base. Lingual membrane with four series of spines, the two next the medial line large and broad, with the inner edge denticulated; no central spine; buccal collar spinose.

1. A. cristata, t. 204. f. 4, t. 222. f. 2 ; Forbes \& Hanley, B.M. t. .f. .

b. Lingual membrane narrow, with twelve or sixteen series of teeth (p. 211 ).

\section{Fam. IV. POLYCERAD五.}

Body limaciform, smooth. Mantle obsolete. Tentacles two, laminated, retractile or non-retractile. Gills non-retractile, with lateral appendages. Lingual membrane rather narrow, with twelve to sixteen series of teeth, two next to the centre on each side large; no central series. Jaws lateral, corneous.

\section{* Tentacles non-retractile.}

\section{Polycera.}

Mantle indistinct, forming a dilated veil, bearing tentacular filaments, and a ridge bearing a row of tubercles on each side of the back; branchial plumes simply pinnate, with a linear branchial appendage on each side. Frontal appendage simple.

1. P. quadrilineata, t. 64 . f. 3, t. 223. f. 1. Var. 1. t. 204. f. 1 . Var. 2. t. 204.f. 3, t. 205.f. 5; Forbes \& Hanley, B.M.t. Y.Y. f. 5 .

2. P. lineata, t. 232. f. 3 .

3. P. typica, t. 204. f. 2.

4. P. cornuta, t. 64 . f. 1 .

5. P. ornata, t. 204 . f. 8.

6. P. citrina, t. 204. f. $6=$ P.Lessonii, D'Orb.Mag.Zool.vii.t. 105; Alder \& Haneock, Monog. t. $24=$ P. modesta, Lovén.

\section{Palio.}

Mantle indistinct, forming a short bilobate veil, tuberculated on the edge, and a ridge bearing a row of tubercles on each side of the back; branchial plumes branched, with more than one tubercular branchial appendage on each side.

1. P. ocellata, t. 227, f. 2 . 


\section{** Tentacles retractile.}

\section{Thecacera.}

Body limaciform, smooth. Mantle obsolete; forehead with a slight plain veil. Tentacles two, broadly laminated, retractile; sheaths moderate, smooth-edged; branchial plumes non-retractile, with a single row of small tubercles round the branchial region. Lingual membrane with twelve or fourteen plates, the two inner plates on each side with a bicuspid spine; no central plate; lateral jaws small, comeous.

l. T. pennigera, t. 236 . f. 3 .

2. T. virescens, Alder \& Hancock, Ann. \& Mag. Nat. Hist. 1851, viii. 290.

c. Lingual menbrane broad, with many series of teeth (p. 213).

Fam. V. TRIOPIDA.

Lingual membrane broad. Teeth in numerous longitudinal rows, equal, or the two inner of each side larger; no central plate? Body depressed. Mantle obsolete, covering the head with linear or subclavate marginal beards. Dorsal tentacles within retractile; sheaths laminated. Gills not retractile.

* Dorsal tentacles laminated. Teeth unequal.

\section{TrROPA.}

Body depressed. Mantle small, covering the head, with marginal appendages. Dorsal tentacles laminated, with slight sheaths; oral tentacles cylindrical. Branchiæ not retractile. Lingual membrane rather broad. Teeth numerous, two innermost with large spines; central plate none or square.

1. T. claviger, t. 67 . f. 1, 2, t. 274. f. 1 ; Forbes \& Hanley, B.M. t. A.A.A.f. 1. Var. T. plumosa, t. 231. f. 2 .

"Central tooth of Triopa claviger none; lateral teeth 8; frst slender, elongated, curved; second wide, hooked, bimucronated at the tip; the others squarish, laminaceous, lying upon each other."Lovén.

"Central tooth of Triopa lacer laminaceous, flat, squarish, ob-

Fig. 117.-Teeth of Triopa lacer.

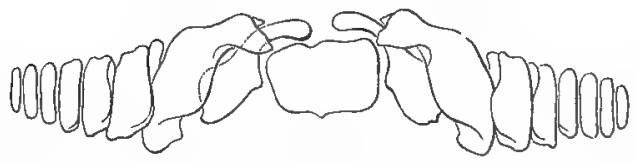

lique; lateral teeth 8 , dissimilar; the first elongated, from an oval 
base produced into an arched neck, unarmed, the tip rounded; second very large, stout, tip clavate, bimucronate, scape inflated; third and following gradually smaller, simple, somewhat rectangular (fg.117)."'

-Lovén.

\section{Euplocamus.}

Body rather depressed; cloak small, covering the head; the edge surrounded with branched appendages. Dorsal tentacles laminated, sheathed; oral tentacles in form of oval lobes. Branchiæ non-retractile. Lingual membrane broad. Teeth numerous, elongate, the three innermost on each side with large broad spines; no central plate; buccal collar spinose.

1. E. crocea, t. 67 . f. 3 , t. 231 . f. 15.

2. E. frondosa, t. 231. f. 1.

3. E. lacunosa, t. 231 . f. 6 .

\section{Plocamoceros.}

Body limaciform. Mantle obsolete, forming an expanded veil over the head, with branched appendages, and two or three tubercles on each side of the back. Dorsal tentacles laminated; oral tentacles flat. Branchiæ branched, non-retractile; a fin-shaped keeled ridge down the hinder part of the back of the tail. Tongue _-? Jaws

1. P. ocellatus, t. 69. f. 1 .

2. P. (Peplidia) Maderæ.

** Dorsal tentacles linear, smooth. Teeth simple, uniform.

\section{4. ÆGIRUS.}

Body convex, covered with tubercles; cloak indistinct, forming a veil over the head and a tubercular ridge on each side. Dorsal tentacles two, linear, smooth, with wide sheaths. Branchial plumes nonretractile. Lingual membrane broad, with numerous simple curved lateral spines; no central plate; an upper corneous jaw.

1. Ar. punctilucens, t. 204. f. 9, t. 231. f. 12, t. 274. f. 2 ; Forbes \& Hanley, B.M. t. A.A.A. f. 2.

2. E. Lessonii, t. 204 . f. 9.

"Central tooth of Egirus punctilucens wanting; lateral teeth about 17 , simple, each forming a bent hook."-Lovén.

\section{Fam. VI. CERATOSOMID无.}

Lingual membrane broad. Teeth conical, spinose, in numerous similar longitudinal rows; no central series. Buccal collar spinose. Cloak indistinct, simple. Dorsal tentacles laminated, sheathed, not retractile. Gills plunose, retractile into a cavity. Body compressed, elevated. 
1. Ceratosoma.

Back produced into a conical prominence behind. Tentacles in mantle. Gills plumose, retractile into a cavity. Mouth subretractile. Teeth in many lines, diverging from the centre.

1. C. trilobata, t. 67 . f. 14 , t. 214 . f. 7 .

\section{Suborder II. InFERobranchia.}

Gills on the under side of the expanded mantle, lamellar.

\section{Fam. VII. PHYLLIDIAD无.}

Dorsal tentacles laminated, retractile within cavities in the cloak. Labial palpi close, conical, small. Gills in the form of radiating folds on the under side, within the edge of the mantle, surrounding the body, interrupted only by the head. Vent medial, postero-dorsal. Cloak large, spinulose, covering the whole body, tuberculated or pustulated. Jaws and tongue none.

\section{Phyllidia.}

Vent dorsal, in the middle of the hinder part of the back.

1. P. ocellata, t. 312 . f. 8 .

2. P. trilineata, t. 312 . f. $3,4,6,7$.

3. P. albo-nigra, t. 312 . f. 2.

4. P. annulata, Gray, Ann. \& Mag. Nat. Hist. 1853, 221.

\section{Fryeria.}

Vent in the middle of the hinder part, in the groove between the mantle and the foot.

1. F. pustulosa, t. 312. f. 1, 5 .

\section{HYPOBRANCHIATA.}

Vent —— Gills —?

1. H. fusca, t. 220 . f. 1 .

Fam. VIII. DIPHYLLIDIADÆ.

Mantle large, bent up on the sides. Dorsal tentacles two, simple, situated in front of the cloak, with a veil above the head. Gills in folds on the under side of the edge of the mantle, which is bent up. Jaws horny. Anus lateral. Digestive organs with a rudimentary gastro-hepatic system. 


\section{Diphyllidia.}

Cloak exposing the head, coriaceous. Tentacles laminated, longitudinally approximated, partially retractile within a common cavity. Veil reflected. Branchiæ of two kinds, the anterior longitudinally folded, the posterior transversely. Tongue broad, with numerous longitudinal series of simple lateral teeth, and a denticulated central tooth. Jaws horny.

1. D. lineata, t. 204. f. 1, t. 205. f. 1, 2, 3, 4; Forbes \& Hanley, B.M. t. K.K.K. f. 1 .

2. D. verrucosa, t. 205 . f. 6 .

3. D. ocellata, t. 205 . f. 5 .

4. D. pustulosa, t. 204. f. 2.

"Central tooth of Diphyllidia lineata wide, convex in front, excavated behind at the base and produced on both sides; cutting edge with one sharp point, left side smoothish, right side crested and denticulated; lateral teeth 30, claw-like, serrated on the lower margin (fig. 118)."'-Lovén.

Fig. 118.-Teeth of Diphyllidia lineata.

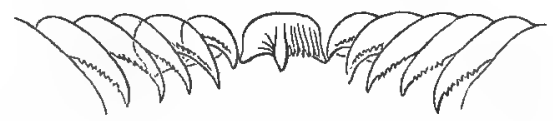

Lingual membrane of Diphyllidia lineata broad, folded in the middle, rounded in front. Teeth $30 \cdot 1 \cdot 30$; central broad, convex in front, hinder base excavated and produced on each side, onecuspid, each side fnely denticulated; lateral claw-like, uniform, equal, thick, apex attenuated, lower edge crenulated. Jaws two, horny, similar.

\section{Suborder III. Polybianchia.}

Gills on the upper surface of the mantle, lamellar or plumose.

A. Tongue-membrane broad, with many longitudinal series of teeth, forming oblique cross rows (p. 219).

\section{Fam. IX. TRITONIADA.}

Body subquadrilateral. Cloak small. Veil large, projecting in front of the head. Liver central. Gills on the sides of the back, lamellar, arranged on the pallial ridge. Teeth in many (21 or 29) longitudinal series. Tentacula two, retractile within the sheath. Vent lateral. Jaws horny, large.

\section{Tritonia.}

Body prismatic, often thick and firm. ITead with digitated veil. Tentacles two, ramose, filamentous, retractile within the plain tubular 
sheath. Gills ramose, plumose, in a single series along a ridge edging the back. Lingual membrane broad, with numerous series of simple or denticulated spines, a tricuspid central series, and a broad plate on each side of it. Jaws very large, horny.

\section{* Frontal tentacula tufted.}

1. T. Hombergii, t. 211 .f. 2 , t. 212. f. $3,5,9$; Forbes $\&$ Hanley, B.M. t. A.A.A. f. 3 .

2. T. acuminata, $t$. 212 . f. 8.

3. T. quadrilateralis, t. 212 . f. 7 .

4. T. decaphylla, t. 198 . f. 11 .

5. T. Costæ, t. 209 . f. 3.

6. T. rubra, t. 212 . f. 3 .

7. T. glamæ, t. 21 1. f. 4, t. 227 . f. l, 2.

8. T. cvanobranchiata, t. 211 . f. 3.

9. T. Thethydea, t. 211 , f. 1 .

** Frontal tentacula simple. Candiella.

10. T. plebeia, t. 209 . f. 2 , t. 212 . f. 4.

11. T. lineata, Alder, Monog. v. t. 4.

12. T. (Duvaucelia) gracilis, Risso, Europ. Mérid.

\section{Fam. X. SCYLLAIDA.}

Body compressed. Cloak produced into lateral lobes bearing the branchial plumes. Anus lateral. Mouth with jaws. Liver central.

\section{Scyllata.}

Body elongate, compressed. Foot linear. Back convex, with two large wing-lobes bearing small gills scattered on their inner surface; forehead with a slight veil. Tentacles : two dorsal with lamellated clubs, retractile; sheaths large. Lingual membrane broad, with a central and numerous series of spinose teeth, all denticulated. Teeth $24 \cdot 1 \cdot 24$. Jaws large, horny. Gizzard armed. Oceanic; living attached by its narrow foot to floating seareed.

I. S. pelagica, t. 203. f. 1, 3 ; Forbes \& Hanley, B.M. t. A.A.A. f. 5 .

2. S. Ghomfodensis, t. 203 . f. 4.

3. S. Quoyii, t. 203. f. 5.

4. S. Hookeri, t. 203. f. 6.

"Central tooth of Scyllaca pelagica compressed, elongated above, cutting edge one-pointed, on each side four to five crested small teeth; lateral teeth on each side 24 , in front moderately produced, slightly curved, claw-like, on each side denticulated, base produced into an obtuse process."-Lovén. 
B. Lingual membrane none. Jaws none (p. 217).

Fam. XI. TETHYAD里.

Body depressed. Mantle indistinct. Veil bearded on the edge, very large, funnel-shaped. Tentacles two, dorsal; branchial plumes alternating with papillæ along the back. Anus lateral, dorsal. Jaws none. Lingual membrane none.

\section{Tetryys.}

Body depressed. Mouth tubular, surrounded by a large funnelshaped veil, fringed on the edge. Tentacles two, retractile, laminated; sheath retractile. Foot large. Gills numerous, branched, alternating with papillæ on each side of the back. Teeth none. Jaws noue. Pelagic; attached to floating plants.

1. T. leporina, t. 210 . f. 1, 2 :

\section{Suborder IV. Cerabranchia.}

Gills on the upper surface of the mantle, fusiform, papillary, simple or branched.

\section{A. Lingual membrane broad, with numerous longitudinal series of teeth (p. 221).}

Reproductive organs with a single external orifice. Liver diffused, and a single central gastro-hepatic vessel. The posterior vessel of the gastro-hepatic system below the ovary.

\section{Fam. XII. DENDRONOTIDA.}

Frontal veil small. Tentacles two, dorsal, laminated and retractile within sheaths. Branchiæ branched or papillose, in a single series along the sides of the back. Vent lateral. Jaws distinct. Lingual membrane broad, with many series of teeth.

\section{Dendronotus.}

Body compressed, elongate, prismatic. Mantle obsolete; frontal veil with branched appendages. Tentacles clavate, laminate, with branched tubular sheath. Gills ramose, in a single series down each side of the back. Foot linear. Lingual membrane rather narrow, with several $(10 \cdot 1 \cdot] 0)$ series of teeth, the central broad, the lateral narrow, all denticulated.

1. D. arborescens, t. 212. f. 1, 6, t. 214. f. 4, t. 225. f. 1, t. 228.

f. 2. Forbes \& Hanley, B.M. t. Z.Z. f. 5 .

2. D. pulchella, Alder \& Hanc. Ann. Nat. Hist. ix. 33.

3. D. felina, Alder \& Hane. Ann. Nat. Hist. ix. 33. 
"Central tooth of Dendronotus arborescens strong, nearly flat, in front truncated, cutting edge triangular, selrulated; lateral teeth 10 ,

Fig. 119.-Teeth of Dendronotus arborescens.

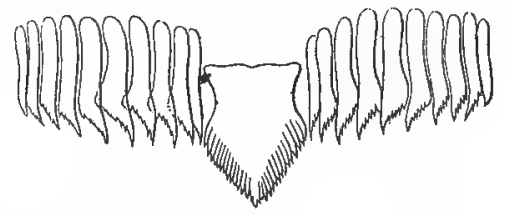

plate-like, adpressed, sublinear, in front extending into a long blunt style, behind slightly arched, obliquely pointed, cutting edge serrulated on the outside, base somewhat produced."-Lovén.

\section{Bornelila.}

Body compressed; cloak obsolete; front of the head with two stellated or fimbriated appendages. Tentacles two, retractile within branched sheaths. Branchiæ plumose, arranged on plain branched pedicels. Tongue - ?

I. B. Adamsii, t. 176 . f. 6 .

\section{Lomanotus.}

Body subquadrilateral, lanceolate, smooth. Head with a veil. Tentacles two, clavate, lamellar, retractile within a sheath. Gills papillose or foliaceous, in a nearly contimuous line on the waved edge of the mantle on the sides of the back. Lingual membrane broad, with numerous series of denticulated spines; no central series. Jaws horny.

]. L. Genei, t. 221 . f. 2.

2. L. marmoratus, t. 221 , f. I Forbes \& Hanley, B.M. t. Z.Z. f. 3.

3. L. flavidus. Eumenes flavida, Alder \& Hanc. Ann. Nat. Hist. xviii. 293.

\section{Fam. XIII. PROCTONOTID正.}

Body depressed. Mantle indistinct. Tentacles four; dorsal pair not retractile, simple or laminated, not sheathed; oral pair small. Gills fusiform, arranged on an obsolete pallial ridge on the sides of the back and in front of the head. Vent postero-dorsal. Jaws horny, strong.

\section{Proctonotus.}

Body ovate, oblong, depressed, pointed behind; forehead with a small distinct veil. Tentacles four ; dorsal simple, linear, not laminated; oral clongate. Gills papillose, ovate, on the edge of the 
sides of the back, and continuous above in front of the head. Vent central, in hinder half of the back. Genital orifice on right side. Jaws plain, horny. Lingual membrane broad, with numerous series of smooth spines.

1. P. mucroniferus, t. 197.f. 1. Forbes \& Hanley, B.M. t. Z.L. f. 2. 2. P.? pilosus (Zephrina pilosa), t. 199. f. 1.

\section{JANus.}

Body ovate, oblong, pointed behind; forehead with a small veil. Tentacles four; dorsal laminated, connected by an arcuated crest; oral tentacles with or without a veil. Gills ovate, on the prominent edges of the back and continuous above the head. Vent central, in hinder part of back. Jaws horny, denticulated; genital orifices on the right side. Lingual membrane broad, with numerous series of simple spines; central series distinct.

1. J. Spinolæ, t. 200. f. 2. Antiopa splendida, Forbes \& Hanley, B.M. t. B.B.B.f. 6.

B. Lingual membrane narrow, with a single central (or very rarely two lateral) series of teeth (p. 219).

a. Reproductive organs with a single external orifice. Liver diffused, and a single central gastro-hepatic vessel.

$\S$ The posterior vessel of the gastro-hepatic system below the ovary.

Fam. XIV. HEROIDÆ.

Mantle obsolete ; frontal veil rather large, plain, produced at the sides. Tentacles two, linear, simple, not retractile. Branchiæ branched or umbellated. Lingual membrane with a central series of large denticulated spines, and two series of simple lateral teeth. Jaws corneous.

\section{Hero.}

Body slender. Foot broadish. Cloak adnate. Tentacles simple, unprotected, contractile. Branchiæe lateral, a simple series on each side, branched like a shrub; labial veil ample, produced on both sides into an oblong lobe.

1. H. formosa.

2. H. fimbriata.

\section{2. ? GeLLina.}

Gill clavate, simple. Teeth —?

1. G. affinis, t. 199. f. 9 . 
3. ? NerEa.

Teeth …?

1. N. punctata, t. 203. f. 2 .

\section{Fam. XV. DOTONIDA.}

Mantle obsolete. "Tentacles two, simple, sheathed at the base, retractile. Gills clavate, compound, muricated or tuberculated, set in a single series on each side of the back. Vent lateral, dorsal. Jaws none.

\section{Doтo.}

Body elongate, subprismatic; forehead with a small simple veil. Tentacles two, dorsal, linear, retractile, with short wide trumpetshaped sheaths. Gills ovate, clavate, with whorls of tubercles, deciduous, in a simple series along each side of the back. Foot linear. Lingual band narrow, with a single central series of large spines.

1. D. fragilis, t. 198. f. 3, 5, 7 ; Forbes \& Hanley, B.M.t.A.A.A. f. $4 *$.

2. D. coronata, t. 198. f. 1, t. 199. f. 8, t. 208. f. 2 ; Voy. Bonite, t. 24*, anat.; Forbes \& Hanley, B.M. t. A.A.A.f. 4.

\section{Melibe.}

Frontal veil large, funnel-shaped, fringed internally. Tentacles small, retractile within long narrow trumpet-shaped sheaths. Branchiæ ovate, tuberculated. Lingual membrane - ?

1. M. rosea, Rang, Man. t. 3. f. 3 .

\section{Fam. XVI. GLAUCID}

Body elongate. Tentacles four, linear, simple, non-retractile. Gill fusiform, arranged in a palmate form on extended footstalks. Anus lateral. Penis spiral, lateral. Jaws distinct. Lingual membrane narrow, with a single series of teeth.

\section{Graucus.}

Head indistinct. Tentacles short. Branchiæ compressed, tapering, arranged on broad flattened footstalks. Foot very narrow, rounded in front. Lingual membrane narrow, with a single central series of plates, bearing a long stout spine and marginal denticles.

1. G. radiatus.

2. G. Atlanticus, t. 201. f. 3, t. 202. f. 4 ; Voy. Bonite, t. 24*. f. $9-11$, t. $24 * *$.

3. G. Draco, t. 202. f. 6 . 
4. G. Forsteri, t. 202. f. 3.

5. G. Eucharis, t. 201. f. 1, 6; Voy. Bonite, t. $24,24 *$, anat.

6. G. Pacificus, t. 201 . f. 4 , t. 202. f. 1, 2, 7.

Laniogerus Elfortii, t. 231. f. 13, is supposed to be only a Glaucus which has lost its gills ; t. 201 . f. $2 \& 5$, from Dr. J. Hooker's MSS., are probably the same.

"Central tooth of Glaucus hexapterygius strong, plate-like, adpressed, base in front on each side produced into a long horn; cutting edge one-pointed, pectinated on each side (fig. 120)." -Lovén.
Fig. 120. - Teeth of Glaucus hexapterygius.

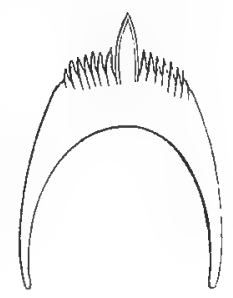

$\$ \$$ The hinder vessel of the gastro-hepatic system above the ovary.

\section{Fam. XVII. EOLIDID $\#$.}

Mantle obsolete. Tentacles four, non-retractile, variable. Gills simple, papillose or linear. Vent lateral. Jaws distinct. The posterior vessel of the gastro-hepatic system above the ovary.

\section{Calma.}

Body depressed, rather broad. Tentacles small, simple, linear. Branchiæ linear, fusiform, clustered on cylindrical footstalks. Foot broad; anterior angles acute. Lingual membrane small, narrow, with a single series of spines.

1. C. glaucoides.

\section{Flabelitina.}

Body linear, slender. Tentacles four; dorsal laminated; oral elongate. Gills linear or fusiform, clustered on footstalks. Foot narrow; anterior angles much produced. Lingual membrane with a central spine with marginal denticles, and two separate plain lateral spines. Spawn in many coils.

1. F. affinis, t. 198. f. 13.

2. F. punctata, t. 206 . f. 2.

3. F. pedata, t. 195. f. 9 .

4. F. Drummondii, t. 273 . f. $1=$ E. tenuibranchialis and E. curta, Alder \& Hancock.

5. F. Cuvieri, t. 195. f. 1, 10.

6. F. Bostoniensis, t. 196. f. 3.

\section{Facelina.}

Body rather slender. Dorsal tentacles laminated; oral tentacles long. Branchiæ linear or fusiform, clustered. Foot narrow, with the anterior angles acute and much produced. Lingual membrane 
with a single central series of large spines, denticulated on the edge. Spawn in many undulating coils.

1. F. coronata, t. 191 . f. 4 , t. 206 . f. 1.

2. F. annulicornis, t. 205. f. 5 .

3. F. minima, t. 205 . f. 4 .

4. F. crassicornis, t. 195. f. 5 .

5. F. subrosacea, t. 195 . f. 4 .

\section{Coryphella.}

Body slender. Dorsal tentacles simple. Branchiæ linear or fusiform, clustered. Foot narrow, with the anterior angle much produced. Lingual membrane with the central series of plates with a large central spine and marginal denticles, and two separate lateral spines, denticulated on the inner margin. Spawn in many undulating coils.

1. C. Landsburgii, t. 273. f. 3 .

2. C. rufobranchialis, t. 273. f, 2 = E. Embletoni, Johnston.

3. C. pellucida, t. 200 . f. 1 .

\section{Favorinus.}

Body slender. Dorsal tentacles with a bulbous swelling; oral tentacles long. Branchiæ linear, flattened, in distant transverse rows; the anterior ones double. Foot narrow, with the anterior angles much produced. Lingual membrane with a single series of plates with a single smooth spine. Spawn of many plain narrow coils.

1. F. albus, t. 192, f. 2 .

\section{Phidiana.}

Body stout. Dorsal tentacles clavate, perfoliate. Labial feelers very large, subulate. Gill in close cross rows. Sides of the foot rounded. Lingual membrane —?

\section{* Foot rounded in front.}

1. P. Patagonica, t. 191. f. 3.

2. P. Inca, t. 191. f. 1, 2, t. 194. f. 8.

3. P. longicauda, t. 194. f. 11 .

4. P. Northumbrica, t. 208. f. 1.

** Foot subulate ir front.

5. P.? cærulescens, t. 194. f. 4.

\section{Eolidia.}

Body depressed, rather broad. Tentacles linear, simple. Branchiæe rather flattened, set in numerous close cross rows. Foot broad; anterior angles acute. Tongue with a single series of broad uniformly pectinated teeth. 
* Front of foot angular.

1. E. papillosa, t. 195. f. 43 , t. 197. f. 6 , t. 268 . f. 8 ; Forbes $\&$. Hanley, B.M. t. B.B.B. f. 1 .

2. E. limacina, t. 194. f. 2.

3. E. Scacchiana, t. 194. f. 5 .

4. E. Cuvieri, t. 195. f. 6 ; Voy. Bonite, t. $24 \beta$.

5. E. ? diversa, t. 196. f. 4 .

6. E. salmonacea, t. 196. f. 5 .

7. E. ? ?, t. 205 . f. 8 .

8. E. Histrix, t. 205. f. 1.

9. E. Peachii, Alder \&. Hanc. Amr. Nat. Hist. i. 190.

I0. E. glauca, t. 272. f. 1 .

11. E. paradoxa, t. 194. f. 7 .

** Foot subulate in front.

The lingual plate of $\boldsymbol{E}$. papillosa has a Fig. 121.-Teeth of Eolidia single pectinated arch; of $E$.glauca a double branchialis.

pectinated arch.-Alder.

Central tooth of Eolidia branchialis wide, plate-like, short, adpressed, arcuated backwards, cutting edge equally pectinated (fig. 121).

\section{Cuthona.}

Body depressed. Head much produced at the sides. Tentacles single, linear. Branchiæ clavate, in close-set rows. Foot broad, rounded in front. Lingual membrane with a single series of plates, with a large spine and marginal denticles.

1. C. nana, t. 272 . f. 2 .

\section{Cavolina.}

Body rather slender. Tentacles linear, simple. Branchiæ linear, generally in rather distant transverse rows. Foot narrow, with the anterior angles rounded. Lingual membrane with a single series of denticulated plates, with the central spine not prominent. Spawn slightly coiled.

1. C. aurantiaca, Alder \& Hancock.

\section{* Front of foot produced, subulate.}

2. ?C. ? exigua, Forbes \& Hanley, B.M. t. B.B.B. f. 4.

3. C. lineata, Alder \& Hanc. Mon.t. 16.

4. C. elegans, Alder \& Banc. Mon. t. 17. f. 2, 3, 4.

5. C. smaragdina, Alder \& Hanc. Mon. t. 17. f. I.

6. C. gracilis, Alder \& Hanc. Ann. Nat. Hist. xiii. I 66.

7. C. peregrina, t. 194. f. $9($ ?), t. 198. f. 14 , t. 205. f. 10.

8. C. longicornis, t. 195 . f. 8 .

9. C. annulata, t. 194 . f. 3. 
10. C. viridis, t. 199. f. 11 ; Forbes \& Hanley, B.M. t. B.B.B. f. 3.

11. C. angulata, t. 200 . f. 3 .

12. C. concinna, t. 192. f. 1 .

** Front of foot subangular.

13. C. olivacea, t. 192 . f. 3 , t. 197. f. 2.

14. C. purpurascens, t. 198. f. 10 .

15. C. cærulea, t. 195 . f. 2.

16. C. pallida, t. 207. f. s..

17. C. amœna, t. 206 . f. 3.

18. C. arenicola, t. 207 . f. 1 .

19. C. Farrani, t. 195. f. 1, t. 199. f. 5.

20. C. rubra, t. 194. f. 1 .

21. C.? Lottini, t. 194. f. 10.

22. C. natans, t. 194 . f. 6 .

23. C.? pinnata, t. 195. f. 3 .

24. C. bella, t. 195 . f. 7 .

25. C.? gymnota, t. 196. f. 2 .

26. C. L? E. Cuvieri, t. 204. f. 4 ; Voy. Bonite, t. 24 A, B, anat.

The branchire of $C$. aurantiaca are in rather close, and of $C$. vipidis in rather distant rows.

\section{Galvina.}

Body stoutish. Tentacles linear, slender ; oral pair short. Branchiæ in rather distant rows, fusiform, inflated. Foot with anterior angles rounded. Lingual membrane with a series of plates with large denticles and short central spine, and two separate plain lateral spines.

1. G. tricolor, t. 193. f. 2, t. 198. f. 4. Branchiæ much inflated.

2. G. angulata, t. 207. f. 2. Branchiæ not much inflated.

\section{Tergipes.}

Body slender. Tentacles subulate, simple. Labial feelers very short. Gills fusiform, inflated, in a single lateral series on each side of the back. Foot narrow, square in front. Lingual membrane with a single series of plates, with a stout central spine and delicate marginal denticles.

1. 'T. laciniatus, t. 198. f. 2 , t. 205 . f. 3,5 .

2. T. Lamarckii, t. 198. f. I2.

3. T. despectus, t. 193. f. 3 .

4. T. - ?, t. 205. f. 2,7 .

5. T. adspersus, Nordm. Mem. Acad. Peters. t. 1. f. 3, 4.

6. T. Edwardsii, Nordm. Mem. Acad. Peters. t. 1. f. 1, 2.

\section{Embletonia.}

Body elongate, slender; forehcad with a flat lobe on each side. 
Mantle indistinct. Tentacles two, sublateral, linear ; oral pair flattened into two lateral lobes. Gills subcylindrical, simple, in a single or double, in part alternating series down each side of the back. Lingual membrane with a single series of plates bearing a central spine and lateral denticles. Orifices on the right side.

1. E. pulchra, Alder \& Hanc. Monog. t. 38. Pterochilus pulcher, Ann. \& Mag. Nat. Hist. xiv. 329.

2. E. minuta, Forbes \& Hanley, B.M. t. B.B.B. f. 5.

\section{Calliopata.}

Gills in lateral series. Tentacles none. Labial feelers elongate, subulate. Front of foot angular.

1. C. bellula, t. 194. f. 5 .

b. Reproductive organs with two external orifices. Body with two posterior latero-gastro-hepatic vessels (p. 221 ).

Fam. XVIII. FIONID

Tentacles four, simple. Branchire papillose, numerous. Vent latero-dorsal. Mouth with jaws. Lingual membrane with a single series of plates.

\section{Fiona.}

Body elongate. Tentacles four, linear; sheaths none, subdorsal; anterior pair similar to oral tentacles of Eolis, but behind the lips. Lingual membrane with a single series of plates, with a short central spine and marginal denticles. Jaws horny. Stomach __? Gills : papillæe irregularly scattered on a subpallial expansion on the sides of the back and meeting behind; a produced membranous margin or fringe on the inner side of each papilla. Vent on right side of the back; orifice of reproduction separate, below the right tentacles.

1. F. nobilis, Alnler \& Hanc. in Brit. Moll. 589.

\section{Fan. XIX. HERM EID.E.}

Tentacles two, dorsal. Branchiæ papillose. Vent dorsal. Jaws none. Lingual membrane with a single longitudinal series of teeth or plates.

\section{Hermat.}

Body elongated, lanceolate. Mantle indistinct. Tentacles two, dorsal, ear-like, involute, grooved externally. Gills fusiform or linear elongate, papillose, on each side of the back. Vent in middle of the 
front of the back before the heart; orifices beneath the right tentacle. Jaws none. ILingual membrane with a single series of plates with a large broad spine.

* Tentacles with both margins terminating at the sides of the head. Body cylindrical.

1. H. bifida, t. 198. f. 6 .

** Tentacles with the anterior margins continuous with the sides of the head, forming a subveil.' Body with the sides depressed and slightly expanded.

2. H. dendritica, t. 205. f. 9, t. 272. f. 3 ; Forbes \& Hanley, B.M. t. Z.Z. f. 1 .

\section{Stiliger.}

Tentacles two, simple. Branchiæ fusiform, arranged in transverse rows on the sides of the back. Anus in front of the heart. Lingual membrane with a single series of plates bearing a stout spine.

1. S. ornatus, t. 194. f. 4.

\section{Alderia.}

Body ovate oblong, rather convex. Mantle indistinct. Tentacles rudimentary or none. Head produced into a lobe on each side. Jaws none. Gills papillose, in cross rows on the sides of the back. Vent central, subposterior; orifices on the right side. Jaws - ? Lingual membrane with a single series of plates, bearing a large central spine.

1. A. modesta, Forbes \& Hanley, B.M. t. C.C.C. f. 1.

\section{Suborder V, Placobranchia.}

Gills on the upper surface of the mantle, lamellar or venose, spread over the surface. Tongue with a single series of teeth.

Fam. XX. ELXSIADAE.

Tentacles two or four. Body limaciform, furnished with two lateral expansions or folds bent up over the back. Gastro-hepatic system much branched. Anus latero-dorsal, in front of the heart. Jaws none. Lingual membrane with a single central series of spinebearing plates.

$\$$ Tentacula distinct, ear-shaped.

1. Elysia.

Body depressed, ovate, with the lateral expansions produced beyond the hinder end of the body and uniting along the mesial line; sur- 
face of body entirely clothed with vibratile cilia. Head distinct. Tentacles two, ear-like. Eyes distant, behind the tentacles. Vent central, subposterior; orifice on right side. Foot narrow. Lingual membrane with a single series of plates, with a large central spine and a spinose buccal collar.-.See $\bar{V}$ oy. Bonite, t. 24 D, anat.

1. E. timida, t. 18. f. 8,9 , t. 180 . f. 12 .

2. E. fusca, t. 180 . f. 10,11 .

3. E. viridis, t. 18 . f. $1-5,7$, t. 146 . f. 4 , t. 176. f. 2,5, t. 180 . f. 14, t. 199. f. 2 ; Forbes \& Hanley, B.M. t. C.C.C. f. 3.

4. E. elegans, t. 199. f. 4.

5. E. australis, t. 180. f. 6 .

\section{Placobranchus.}

Tentacles four. Back with two lateral membranous expansions, having their upper surface covered with folds. Lingual membrane

1. P. ocellatus, t. 176. f. 4 .

\section{Suborder VI. Pellibranchia.}

Gills: none distinct, the function being performed by the skin. Tongue with a single series of teeth.

\section{Fam. XXI. LIMAPONTIADAE.}

Tentacles two or wanting. Body depressed. Back without appendages. Anus dorsal, posterior. Jaws none. A spinose buccal collar. Lingual membrane with a single series of large spines.

\section{$\S$ Tentacles crest-like.}

\section{l. Limapontia.}

Body oblong, depressed in front, elevated and rounded behind. Head distinct, arched and keeled on the sides. Tentacles wanting; eyes at their hinder ends. Back plain, without appendages. Vent dorsal, subposterior.

1. L. nigra, t. 177 . f. 3,4 ; Forbes $\&$ Hanley, B.M. t. C.C.C. f. 4. 2. L. cærulea, t. 199 . f. 7 .

\section{Actaonia.}

Body oblong. Head large, distinct. Tentacles: two flattened lobes at the sides of the head, prolonged behind into points. Eyes behind the tentacles. Sides of the back with a tubercular ridge in the region of the anus. Vent dorsal, subposterior. Lingual menbrane with a single central series of plates with a large broad spine. A spinal buccal collar. 
I. A. corrugata, t. 177.f. 2 ; Forbes \& Hanley,B.M. t. C.C.C. f. 5.

2. A. senestra, t. 199 . f. 4 .

\section{$\S \S$ Tentacles linear.}

3. Ictis.

"Body oblong; back elevated; head slightly angulated, bearing two linear tentacles on the dorsal aspect, behind and exterior to which are the eyes; vent a little behind the centre of the back." Teeth 1. I. Cocksii, t. 177.f. 1 ; Forbes \& Hanley, B.M. t. C.C.C.f. 6.

\section{Fucola.}

\section{Teeth - ?}

1. F. rubra, t. 180. f. 13.

\section{Pelta.}

Teeth - ?

1. P. coronata, t. 199. f. 6 .

\section{Fam. XXII. PHYLLIRRHOID床.}

Tentacles two, dorsal, linear, elongate, retractile. Head distinct. Tail compressed, truncated. Mouth with jaws. Body compressed. Lingual membrane with a single central series of plates with numerous denticles. Vent lateral.-See Leuckart, Arch. Naturg. 1853, 243, and Krohn, Arch. Naturg. 1853, 278.

\section{l. Phyllirrhö̈.}

Tentacles elongate, subulate, spirally twisterl; body vertically compressed; gills, none external; jaws distinct.

1. P. bucephala, t. 12. f. 4, t. 15. f. 6 ; Voy. Bonite, t. 24, anat.

2. P. Lichtensteinii, t. 153. f. 4 .

3. P. amboinensis, t. 153. f. 3.

4. P. roseum, t. 153. f. 2.

5. P. punctulatum, t. 153 . f. 1 .

6. P. rubrum, t. 153. f. 5. 




\section{CATALOGUES}

of

\section{'THE ZOOLOGICAL COLLECTION}

IN

\section{THE BRITISH MUSEUM.}

\section{VERTEBRATA.}

List of Mammalia. By Dr. J. E. Gray, F.R.S., F.L.S. \&zc. 1843. $2 s .6$.

Catalogue of the Mammalia. By Dr. J. E. GrAy, F.R.S. \&c.

Part 1. Cetacea. 12mo, 1850. 4s., with Plates.

Part 2. Seals. 12mo, 1850. 1s. 6d., with Woodcuts.

Part 3. Hoofed Quadrupeds. Section I. (Ungulata furcipeda). 12mo. 1852, with Plates of Genera, $12 \mathrm{~s}$.

This work contains the description of the genera and species, and figures of the chief characters of the genera.

List of Mammalia and Birds of Nepaul, presented by B. $\mathbf{H}$. Hodgson, Esq., to the British Museum. By Dr. J. E. GraY and G. R. GRAY. 12mo. 1846. 2s.

List of Genera of Birds. By G. R. GRAX, F.L.S. 12mo, 1855. 4s. List of Birds. By G. R. GRaY, F.L.S., F.Z.S. \&c.

Part 1. Raptorial. Edition 1, 1844 ; edition 2, 1848. $3 s$.

Part 2. Passeres. Section I. Fissirostres. 1848. $2 s$.

Part 3. Gallinæ, Grallæ and Anseres. 1844. 2s. (Out of Print.)

Part 3. Section I. Ramphastidx. 1855. $6 d$.

Part 4. Columbæ. 1856. 1s. 9d.

List of British Birds. By G. R. Gray, F.L.S. \&c. 12mo. 1850. 4 s,

List of the Eggs of British Birds. By G. R. GRAY, F.L.S. \&c. 12mo. 1852. $2 s .6 d$.

Catalogue of Shield Reptiles. By Dr. J. E. Grax, F.R.S. \&c.

Part 1. Testudinata. 4to. 1855. £1:10s. With figures of all the new species, and of the skulls of the different genera.

Catalogue of Reptiles. By Dr. J. E. Gray, F.R.S., V.P.Z.S. \&c. Part 1. Tortoises, Crocodiles and Amphisbrenians. 1844. 1s, Part 2. Lizards. 1845. 3s. $6 d$.

Part 3. Snakes (Crotalidæ, Viperidæ, Hydridœ and Boidæ). 12mo. 1849, 2s. 6d. 
Catalogue of Amphibia. By Dr. J. E. GraY, F.R.S., V.P.Z.S. Part 2, Batrachia Gradientia. 12mo, 1850. 2s.6d. With Plates of the Skulls and Teeth.

Catalogue of Fish. By Dr. J. E. Gray, F.R.S.,F.L.S.,V.P.Z.S. Part 1. Cartilaginous Fish. 12mo, 1851. 3s. With two Plates.

These Catalogues of Reptiles, Amphibia, and Fish, contain the characters of all the genera and species at present known; the latter are illustrated with figures of the genera.

Catalogue of Fish, collected and described by L. T. Gronow. 12mo. 1854. 3s. 6d.

Catalogue of Lophobranehiate Fish. By Dr. J. J. Ka up. $12 \mathrm{mo.}$ 1856. 2s. With Plates.

Catalogue of Fish. By Dr. J. J. Kaup. 8vo. With many Plates. Part 1. Apodes, \&c. 1856. 10s.

List of British Fish ; with Synonyma. By A.WHite, F.L.S. \&c. $12 \mathrm{mo}$. 1851. 3s.

List of Osteological Specimens. By Dr. J. E. Gray, F.R.S. \&c. and G. R. GRAY, F.L.S. 12mo. 1847. $2 s$.

\section{ANNULOSA.}

Catalogue of Lepidoptera. By G. R. GRAY, F.L.S., F.Z.S.

Part 1. Papilionidæ, with coloured figures of the new species. 4to. 1852. £ $1: 5 s$.

List of Lepidopterous Insects.

Part 1. Papilionidæ, \&c. 12mo. 2nd edit. 1856. By G. R. GraY, F.L.S.

Part 2. Erycinidæ, \&c. 12mo. 1847. 9d. By E. DoubleDAX, F.L.S.

Part 3. Appendix to Papilionidæ, Erycinidæ, \&c. 1848. 9d.

List of Lepidopterous Insects, with descriptions of new species. By Francis Walker, F.L.S.

Part 1. Lepidoptera Heterocera. 12mo. 1854. 4s.

Part 2. 1854. 4s. 6d.

Part 3. 1855. 3s.

Part 4. 1855. 3s.

Part 5. 1855. 4s.

Part 6, 1855, 3s, 6d.

Part 7. 1856. 4s. 6d. Part 8. 1856. 3s. 6d. Part 9. 1856. 4s. Part 10, 1857. 3s. 6d. Part 11. 1857. 3s. 6d. 
List of British Lepidoptera; with Synonyma. By J. F. STEPHens, F.L.S., and H. T. Stainton, M.E.S.

Part 1. 12mo. Ed. 2. 1856. 2s. Part 3. 1853. 9d.

Part 2. 1852. 2s.

Part 4. 1854. 3s.

List of Hymenopterous Insects. By F. WALKER, F.L.S.

Part 1. Chalcididx. 12mo. 1846. 1s. $6 d$.

Part 2. Additions to Chalcididæ. 1848. $2 s$.

Catalogue of Hymenopterous Insects. By F. Sмiтн, M.E.S.

Part 1. Andrenidæ, \&c. 12mo. 1853. 6s., with Plates.

Part 2. Apidæ. 1854. 6s., with Plates.

Part 3. Mutillidæ and Pompilidæ. 1855, 6s., with Plates.

Part 4. Crabronidæ, \&c. 1856. 6s., with Plates.

Part 5. Vespidæ. 1857. 6s., with Plates.

Catalogue of British Hymenoptera. By F. SMITH, M.E.S.

Part 1. Apidæ. 12mo. 1855. 6s.

Catalogue of British Ichneumonidx. By Thomas Desvignes, M.E.S. 12mo. 1856. 1s. $y d$.

List of British Aculeate Hymenoptera; with Synonyma, and the description of some new species. By F. Sмгтн. 1851. $2 s$.

Catalogue of Dipterous Insects. By F. WALKER, F.L.S.

Part 1. 12mo. 1848. Part 4. 1849. 6s.

3s. 6d. Part 5. Supplement I. 1854. 4s. 6d.

Part 2. 1849. 3s. 6d. Part 6. Supplement II. 1854. 3s.

Part 3. 1849. 3s. Part 7. Supplement1II.1855.3s.6d.

Catalogue of Homopterous Insects. By F. WALKER, F.L.S. With Plates.

Part 1. 12mo. 1850. 3s. 6d. Part 3. 185l. 3s. 6d.

Part 2. 1850. 5s. Part 4. 1852. 4s.

Catalogue of Neuropterous Insects. By F. WALKER, F.L.S.

Part 1. 12mo. 1852. 2s.6d. Part 3. 1853. 1s. 6d.

Part 2. 1853, 3s.6d. Part 4. 1853. ls.

Catalogue of Hemipterous Insects. By W. S.Dallas, F.L.S.\&c. With Plates, Part 1. 12mo. 1851. 7s. Part 2. 1852. $4 s$.

The Catalogues of Hymenopterous, Dipterous, Homopterous and Hemipterous Insects contain the description of the species in the Museum which appeared to be undescribed.

Catalogue of British Bruchidæ, Curculionidæ, \&c. Вy ЈонN WALTON, F.L.S. $12 \mathrm{mo}$. 1856.

Catalogiue of Cassididæ. By Professor Boheman. 12mo. 1856. 3s. 
Nomenclature of Coleopterous Insects (with characters of new species).

Part 1. Cetoniadx. 12mo. 1817. 1s. By A. Whiте, F.L.S. \&c.

Part 2. Hydrocanthari. 1847. 1s. 3d. By A. Whire, F.L.S.

Part 3. Buprestidæ. 1848. 1s. By A. Whjte, F.L.S.

Part 4. Cleridx. 1849. $1 s .8 d$. By A. Whrte, F.L.S.

Part 5. Cucujidæ. 1851. 6d. By F. Sмrтh, M.E.S.

Part 6. Passalidæ. 1852. 8d. By F. Smith, M.E.S.

Part 7. Longicomaia. By A. Whrter, F.L.S. With Plates. Part 1. 1853. 2s.6d. Part2. 1855. 3s, 6d.

List of Myriapoda. By G. NEwPorT, F.R.S. \&c. 12mo. 1844. 4 d.

Catalogue of Myriapoda. By G. Newpont, F.R.S. \&c.

Part 1. Chilopoda. 12mo. 1856. 1s. 9 d.

List of British Anoplura, or Parasitic Insects; with Synonyma. By II. Denny, 12mo. $1 s$.

List of Crustacea; with Synonyma. By A. White. 1847. 2s.

List of British Crustacea; with Synonyma. By A. Whrte, F.L.S. 12mo. 1850. 2s, $6 d$.

Catalogue of Eutozoa; with Plates. By W. BAIrd, M.D., F.L.S. 12mo. 1853. $2 s$.

Catalogue of British Worms. By G. Johnston, M.D. 8vo. 1856. 10s. With Plates.

\section{MOLLUSCA.}

Guide to the Collection of Mollusca. By Dr. J. E. Gray, F.R.S. \&c. 8vo. Part 1. 1856. 5s.

Catalogue of the Mollusea. By Dr. J. E. GrAY, F.R.S. \&c. Part 1. Cephalopoda Antepedia. 12mo. 1849. $4 s$.

Part 2. Pteropoda. 1850, $1 s$.

Catalogue of Bivalve Mollusca. By Dr. J. E. GrAY, F.R.S. \&e. Part 1. Placuniadæe and Anomiadæ. 12mo. 1850. 4d.

Part 2. BrachiopodaAncylopoda. 1853.3s. Figures of genera.

Containing the characters of the recent and fossil genera, and the descriptions of all the recent species at present known.

Catalogue of Phaneropneumona or Oper'culated Terrestrial MolJusca. By Dr. Louis Preifrer and Dr. J. E. Gray. 1852. $5 \mathrm{~s}$.

Catalogue of Conchifera. By M. Deshayes.

- Part 1. Veneride, \&c. 12mo. 1853. 3s. Part 2. Petricolidæ. $6 d$. 
List of British Mollusca and Shells; with Synonyma. By Dr. J. E. GrAY, F.R.S.

Part 1. Acephala and Brachiopoda. 12mo. 1851. 3s.6d.

Catalogue of Pulmonata. By $\mathrm{D}_{r}$. Lovis Pferffer and Dr. J. E. GRAY, F.R.S.

Part 1. 12mo. 1855. 2s. $6 d$.

List of the Shells of the Canaries, described by M. D'Oнвigny. 12mo. 1854. $1 s$.

List of the Shells of Cuba, described by M. D'ORBIGNy. $12 \mathrm{mo}$. 1854. $1 s$.

List of the Shells of South America, described by M. D'ORBIGNY, 12mo. 1854. $2 s$.

List of the Mollusea and Shells collected and described by MM. EydouX and Souleyet. 12mo. 1855. 8d.

Nomenclature of Mollusce. By Dr. W. BAIRD, F.L.S. \&c.

Part 1. Cyclophoridx. 12mo. 1851. 1s,6d.

\section{RADIATA.}

Catalogue of Marine Polyzoa. By G. Busk, F.R.S.

Part 1. Chilostoma. 12mo. 1852. 17s. With Plates.

Part 2. Chilostoma. 12mo. 1854. 15s. With Plates.

List of British Radiata; with Synonyma. By Dr. J. E. GRAY, F.R.S. 12mo. 1848. $4 s$.

List of British Sponges; with Synonyma. By Dr. J. E. GRAY, F.R.S. 12mo. 1848. 10d.

Catalogue of the Recent Echinida. By Dr. J. E. Gray, F.R.S. Part 1. Echinida irregularia. 12mo. 3s. 6d., with Plates.

\section{BRITISH ZOOLOGY.}

List of the British Animals; with Synonyma and references to figures.

Part 1. Radiata. By Dr. J. E. Gray. 1848. $4 s$. Part 2. Sponges. By Dr. J. E. GRAY. 1848. $10 d$.

Part 3. Birds. By G. R. Gray, 1850. 4s.

Part 4. Crustacea. By A. White. 1850. $2 s, 6 d$.

Part 5. Lepidoptera. By J. F. Stephens. 1850. Ed. 2. 1856. 1s. $9 d$. 
Part 6. Hymenoptera. By F. SмrтH. 1851. 2s.

Part 7. Mollusca Acephala and Brachiopoda. By Dr. J. E. Gray, 1851, 3s. 6d.

Part 8. Fish, By A. White. 1851. $3 s$.

Part 9. Eggs of British Birds. By G. R. Gray. 1852. $2 s .6 d$.

Part 10. Lepidoptera (continued). By J. F. Stephens. 1852. $2 s$.

Part 11. Anoplura or Parasitic Insects. By H. Denny, $1 s$.

Part 12. Lepidoptera (continued). By J. F. Stephens. 1852. $9 d$.

Part 13. Nomenclature of Hymenoptera. By F. Sмrтн. 1853. $1 s, 4 d$.

Part 14. Nomenclature of Neuroptera. By A. White. 1853. $6 d$.

Part 15. Nomenclature of Diptera. By A. WhITE. 1853. $1 s$.

Part 16. Lepidoptera (completed). By H. T. Stainton, M.E.S. 1854. 3s.

Catalogue of British Hymenoptera (Bees). By F. Sмптн. 1855. $6 s$., with plates.

Catalogue of British Ichneumonidæ. By Thomas Desvignes, M.E.S. 12mo. 1856. 1s. $9 d$.

Catalogue of British Bruchidæ, Curculionidæ, \&c. By ЈонN WALTON, F.L.S. 12mo. 1856.

N.B.-These Catalogues can be obtained at the Secretary's Office in the British Museum; or through any Bookseller.

\section{Books ILLUSTrating or Describing parts of the Zoological Collections.}

The Illustrated Natural History. By the Rev. J. G. WooD, M.A., F.L.S. \&c. New edition. 12mo. 1855.

Illustrations of Indian Zoology, from the Collection of MajorGeneral Thomas Hardwicke. By .Dr. J. E. GRAy, F.R.S. Folio. 2 vols. 1830-1835.

Zoology of the Voyage of H.M.S. Beagle. Edited by Crartes Darwin, F.R.S. 4to. 1840-1844.

Zoology of the Voyage of H.M.SS. Erebus and Terror. Edited by Sir JоHN RICHA RDson', M.D., F.R.S. \&c., and Dr. J. E. GRAY, F.R.S. 4to. 1844-1845.

British Museum-Historical and Descriptive. 12mo. 1855.

Natural History of the Animal Kingdom. By W. S. Dallas, F.L.S. \&c. Post 8ro. 1855. 
Zoological Miscellany. By W. E. LEACH, M.D., F.R.S. 8 vo. 3 vols.

Spicilegia Zoologica. By Dr. J. E. GrA y, F.R.S. 4to. 1829-1830.

Zoological Miscellany. By Dr. J. E. Gray, F.R.S. 8vo. 1831.

Knowsley Menagerie. Part 2. Hoofed Animals. By Dr. J. E. GrAy, F.R.S. Folio. 1850.

A Monograph of the Macropodidæ. By John Gould, F.R.S. Folio. 1841-1844.

Mammals of Australia. By JoHn Govld, F.R.S. Folio. 1845.

Popular History of Mammalia. By A. WhITE, F.L.S.

Popular History of Birds. By A. WhITE, F.L.S.

Genera of Birds. By G. R. GraY, F.L.S. Illustrated by plates by D. W. Mrtcheli, Sec. Z.S. Folio. 3 vols. 1844-1849.

The Birds of Jamaica. By P. H. Gosse, F.R.S. 8vo. 1847.

Illustrations of the Birds of Jamaica. By P. H. Gosse, F.R.S. 8vo. 1849.

Monograph of Ramphastidæ. By Joнn Govld, F.R.S. Folio.

Birds of Australia. By JoHn Gould, F.R.S. Folio. 1848.

Report on the Ichthyology of the Seas of China and Japan. By Sir John Richardson, M.D., F.R.S. 8vo. 1846.

Fauna Boreali-Americana. The Fish. By Sir John Richardson, M.D., F.R.S. \&c. 4to. 1836. With Plates.

Synopsis Reptilium. Part 1. Cataphracta. By Dr. J. E. GrAY, F.R.S. 8vo. 1831.

Illustrations of British Entomology. By James F. STEPhens, F.L.S. 10 vols. 8 vo. $1827-1835$.

A Systematic Catalogue of British Insects. By J. F. Stephens, F.L.S. 8vo. 1829 .

The Nomenclature of British Insects. By J. F. Stephens, F.L.S. 8 vo. $1829 \& 1833$.

A Manual of British Coleoptera. By J. F. Srephens, F.L.S. 12 mo. 1839.

Insecta Britannica. Diptera. By F. WALKer, F.L.S. 87o. $1851-1856$.

Monographia Chalciditum. By F.WALkeR, F.L.S. 8vo. 1839.

Entomology of Australia. Part l, Phasmidæ. By G. R. GRAY, F.L.S. 4 to.

Synopsis of species of Phasmidx. By G. R. Gray, F.L.S. 8 vo. 1835. 
Genera of Diurnal Lepidoptera. By Edwand Doubleday, F.L.S., and J. O. Westwood, F.L.S. Illustrated by W. C. Hewitson. 4to. 2 vols. 1846-1850.

Monographia Anoplurorum Britannis, or British species of Parasitic Insects. By Henry Denny, F.L.S. 8vo. With Plates.

Fauna Boreali-Americana. The Insects. By W. KIRBy, T.R.S. 4to. 1837. With Coloured Plates.

Insecta Maderensia. By T. Vernon Wollaston, M.A., F.L.S. 4to. 1854. With Plates.

Malacostraca Podophthalmia Britanniæ. By W. E. LeACH, M.D., F.R.S. 4to. 1817-1821.

A Monograph of the Subclass Cirripedia. ByCharles Darwin, F.R.S. 8 vo. 2 vols. 1854.

Natural Histery of the British Entomostraca. By W. BAIRD, M.D., F.L.S. \&c. 8ro. 1850:

Figures of Molluscous Animals, for the use of Students. By Maria Emma Gray. 3 vols. 8vo. 1850-1854.

A Synopsis of the Mollusca of Great Britain. By W. E. LeACH, M.D., F.R.S. 8vo. 1852.

Catalogue of the Land Shelis of Jamaica. By C. B. AdAms. 8 vo. 1851.

Catalogue of Testaceous Mollusca of the North-east Atlantic and neighbouring Seas. By R. MAcAndrew, F.R.S. Bro. 1850 .

Illustrations of the Geology of Yorkshire. By Jofin Phillips, F.R.S. 4to. 1836.

A Monograph of the Crag Mollusca. By Searles V. Wood, F.G.S. 4to. 1850.

A History of British Starfishes. By Edwand Forbes, T.R.S. 8 ro.

A History of the British Zoophytes. By George Johnston, M.D. 8vo. 1838.-Ed. 2. 8vo. 1847.

A History of British Sponges and Lithophytes. By George JoHnston, M.D. 8vo. 1842.

A Synopsis of the British Diatomacex. By W. Sмrтн, F.L.S. 8vo. 2 vols. 1854-1856. The Plates by T. West.

Proceedings of the Zoological Society. Series 1 and 2.

Transactions of the Entomological Society.

May 1857. 



